\title{
INCENTIVO FISCAL AMBIENTAL: PARÂMETROS E LIMITES PARA SUA INSTITUIÇÃO À LUZ DA CONSTITUIÇÃO FEDERAL DE 1988
}

\author{
Tese apresentada como exigência parcial à obtenção do \\ título de Doutor em Direito, no âmbito do Programa de \\ Pós-Graduação da Faculdade de Direito da \\ Universidade de São Paulo, sob orientação do Professor \\ Dr. Estevão Horvath.
}

FACULDADE DE DIREITO DA USP

SÃO PAULO 


\section{BANCA EXAMINADORA:}

Orientador: Professor Dr. Estevão Horvath

Professor Arguidor: Dr. Fernando Facury Scaff

Professor Arguidor: Dra. Ana Maria de Oliveira Nusdeo

Professor Arguidor: Dr. Saulo José Casali Bahia

Professor Arguidor: Dr. Hugo de Brito Machado Segundo 
Quando a última árvore tiver caído, quando o último rio tiver secado, quando o último peixe for pescado, vocês vão entender que dinheiro não se come.

Provérbio dos Índios Sioux

Que o nosso tempo seja lembrado pelo despertar de uma nova reverência face à vida, pelo compromisso firme de alcançar a sustentabilidade, a intensificação dos esforços pela justiça e pela paz e a alegre celebração da vida.

Carta da Terra 


\section{AGRADECIMENTOS}

Aos meus pais e irmão, pela nossa plena cumplicidade.

Pelo incentivo de toda a minha família, em especial, de meus avós, tios e primos.

Ao meu querido orientador, professor Estevão Horvath, que não se contenta apenas com transmitir seus conhecimentos na área jurídica, e dissemina lições de ética e de arte. $\mathrm{O}$ convívio e o aprendizado com ele remetem à emoção e à profundidade da mais bela sinfonia.

Ao professor Saulo Casali Bahia, o meu eterno agradecimento por se fazer presente em cada passo da minha vida acadêmica, trazendo muitas luzes sobre todos os temas e dilemas enfrentados.

Devo agradecimento a todos os meus amigos. Faço expressa menção a alguns, sem os quais este trabalho jamais se corporificaria: Valter Pedrosa, Adriano Steinway, Jorge Soto, Danilo Bastos, Manoel Mota Fonseca, Maurício Bezerra, Carolina Landim, Joana Machado, Vanessa Tavares Figueirêdo, José Marques Domingues, Raquel Machado, Marcela Nardelli, Osvaldo Lobato, Juliana Brandão, Joanna Nascimento, Milton Mendes, Fernando Mota, Rodrigo Freire, Bernardo Vita, Andréa Maia, Guilherme Borges, Janaina Daltro, Andressa Torquato, Vitor Andrade, Daniel Strand, Marcos Neder, Simone Musa, Isamara Campos, Rodrigo Saito, Valéria Zoteli, Elisabeth Martos, Pedro Satiro, Daniel Santiago e José Paulo Brandão. 


\section{RESUMO}

A presente tese tem como objeto a formulação de limites jurídicos à instituição de incentivos fiscais ambientais. Partindo da constatação de que a crise ambiental ora em voga requer que sejam adotados diversos instrumentos para conter a poluição e inibir a escassez dos ativos ambientais, geradas pelo atual padrão de produção e consumo, envereda-se pela análise da tutela constitucional da questão ambiental. Examina-se, com destaque, a parte final do comando contido no art. 170, VI, da Lei Maior, cuja norma (inserida no rol dos princípios da ordem econômica) estabelece um tratamento diferenciado de produtos e serviços, bem como dos seus processos de produção, de acordo com o critério de proteção ambiental. Ademais, é conferida ênfase ao conteúdo plasmado no art. 225 da CF/88, segundo o qual a preservação e a defesa do meio ambiente consubstanciam um dever do Poder Público e da Sociedade, sendo o meio ambiente ecologicamente equilibrado um direito das presentes e futuras gerações. Diante dos robustos comandos que ressaltam o dever de todos de promover, no país, um desenvolvimento sustentável, investigam-se as formas de atuação do Estado na economia e os fundamentos que embasam intervenções de tal ente sobre as condutas dos particulares, com vistas a induzir comportamentos ambientalmente orientados. Nesta trilha e considerando que nos Estados atuais a tributação consubstancia a sua maior fonte de receita, envolvendo, portanto, considerável parcela da riqueza da nação, analisa-se o alcance da tributação extrafiscal no que concerne à concessão de incentivos fiscais para o fomento de atividades que impactem positivamente o meio ambiente. Por ser o Brasil um Estado Democrático e Social de Direito, regido por uma Carta Política que alberga inúmeros interesses, bens e princípios conflitantes, a investigação das fronteiras para a instituição dos estímulos tributários em comento é pautada pela análise ponderada dos mais diversos desígnios constitucionais. Busca-se identificar, à luz do ordenamento jurídico brasileiro, balizas que irão permitir que a lei tributária instituidora do incentivo fiscal ecológico consubstancie instrumento hábil a induzir condutas ambientalmente orientadas, sem restringir desproporcionalmente outros fins, princípios e valores constitucionais, a exemplo da igualdade e da livre concorrência. Neste compasso, pretende-se demonstrar que a criação do instituto em tela, realizada com base nos parâmetros ora sistematizados, constitui significativo instrumento voltado à construção de uma economia baseada nos pilares da sustentabilidade. Assim, espera-se, em última análise, contribuir para que os entes tributantes veiculem, com maior segurança e propriedade, estímulos fiscais de viés ambiental, disseminando-se diplomas legais que efetivamente concretizam a defesa do meio ambiente.

Palavras-chave: Incentivo fiscal; meio ambiente; sustentabilidade; tributação; desoneração; defesa do meio ambiente; redução do impacto ambiental; igualdade; proporcionalidade; livre concorrência. 


\section{ABSTRACT}

\section{Fiscal environment incentive: parameters and boundaries for Implementation in line with the 1988 Federal Constitution}

The purpose of this thesis is to define legal boundaries in order to establish environmental fiscal incentives. It required an analysis of the matter concerning environment constitutional management, due to the fact that the existing environment crisis demands the implementation of several tools to restraint pollution and inhibit the shortage of environment assets caused by current production and consumption standards. It is pointed out the final item of the command contained in the Art. \# 170 of the Federal Constitution, whose norm - included within the roll of the Economical Order principles directs towards differentiate handling of products and services, besides their related production processes in line with environment protection criteria. Also, the Art. \# 225 of the 1988 Federal Constitution - included under the Title concerning Social Order emphasizes the fact that both Government and Society are accountable for the preservation and defense of the environment and that an ecologically balanced environment is the right to present and future generations. Considering the stressed commands that refer to the general responsibility to support sustainable development in the country, this thesis assesses the way the State acts in the economy and the basis for intervening in the conduct of private citizens, aiming at promoting environment-oriented behavior. Following this line of thought and taking into account that taxes represent the States' major source of income, thus absorbing large part of the country wealth, it is analyzed the extra-fiscal taxation range related to the concession of fiscal incentives to promote activities involving positive impact on the environment. Therefore, since Brazil is a Democratic and Social of Right State, ruled by a political Federal Constitution that comprehends several conflicting interests, goods and principles, the investigation of the boundaries to implement the fiscal incentives, in which this thesis is focused, is based upon thorough analysis of a great variety of constitutional directives. Its target is to identify, under the Brazilian judicial point of view, the foundations to allow that the fiscal law to support the ecological fiscal incentive substantiates an appropriate instrument to encourage environment-oriented actions, without restraining other constitutional objects, principles and values disproportionately, as equality and free competition principles, among others. As a consequence, based on the analyzed parameters, this thesis intends to demonstrate that the establishment of the institute therein proposed represents relevant tool to construct an economy founded on sustainability. Therefore, the expectation is that, at least, this work might contribute to the tax offices to promote more solid and accurate environmental fiscal incentives, and issue legal norms in order to consolidate the environment defense efficiently.

Key-words: Fiscal incentive; environment; sustainability; taxation; exoneration; environment defense; reduction of environment impact; equality; proportionality; free competition. 


\section{RIASSUNTO}

\section{Tassa d'incentivi ambientale: i parametri ed i limiti per la loro istituzione alla luce della Costituzione del 1988.}

La presente tesi ha per oggetto la formulazione di limiti giuridici all'istituzione di tasse di incentivi fiscali ambientali. Partendo dalla constatazione che la crisi ambientale ora in corso richieda l'adozione di diversi strumenti per reprimere l'inquinamento e inibire la scarsità degli attivi ambientali, generati dall'attuale modello di produzione e consumazione, ci conduciamo a un'analisi della protezione costituzionale della questione ambientale. Esaminiamo, in un primo piano, la parte finale del comando previsto nell'art. 170, VI, della Legge Maggiore, la cui norma (inserita nella serie dei principi dell'ordine economico), stabilisce un trattamento distinto di prodotti e servizi, nonché i suoi procedimenti di produzione, secondo il criterio di protezione ambientale. Inoltre, viene attribuita una certa evidenza al testo formato nell'art. 225 della $\mathrm{CF} / 88$, secondo il quale la preservazione e la difesa dell'ambiente concretizzano un dovere del Potere Pubblico e della Società, essendo l'ambiente ecologicamente equilibrato un diritto delle presenti e future generazioni. Davanti i forti comandi che evidenziano il dovere di tutti nel senso di promuovere, nel nostro paese, uno sviluppo sostenibile, vengono investigate forme di attuazione dello Stato nell'economia e i fondamenti che servono di base a interventi di questo Ente a proposito de delle condotte degli enti privati, ai fini di indurre comportamenti ambientalmente orientati. In questo senso e considerando che negli Stati attuali la tassazione concretizza la sua più grande fonte di reddito, coinvolgendo, pertanto, una grande parte della ricchezza del paese, analizziamo il ricavo della tassazione extra fiscale per quanto riguarda la concessione di tasse di incentivi fiscali per la promozione di attività che abbiano un impatto positivo sull'ambiente. Essendo il Brasile uno Stato Democratico e Sociale di Diritto, regolato da una Lettera Politica che abbarca interessi vari, beni e principi in conflitto, l'investigazione delle frontiere per l'istituzione degli stimoli tributari in questione è orientata dall'analisi ponderata dei più variati propositi costituzionali. Cerchiamo di identificare, alla luce dell'ordinamento giuridico brasiliano, i limiti che permetteranno che la norma tributaria che instituisce la tassa di incentivo fiscale ecologico concretizzi uno strumento capace di indurre comportamenti ambientalmente orientati, senza restringere sproporzionalmente altri fini, principi e valori costituzionali, come per esempio uguaglianza e libera concorrenza. In questo senso, pretendiamo dimostrare che la creazione dell'istituzione in questione, realizzata in base ai parametri ora sistematizzati, costituisce un importante strumento per la costruzione di un'economia basata sui pilastri della sostenibilità. In questo modo, speriamo, in un'ultima analisi, contribuire affinché gli enti tributanti propaghino, con una maggior sicurezza e proprietà, stimoli fiscali in materia ambientale, diffondendo diplomi legali che concretizzino effettivamente la difesa dell'ambiente.

Parole chiave: Incentivi fiscali; ambiente; sostenibilità; tassazione; sgravi fiscali; difesa dell'ambiente; riduzione dell'impatto ambientale; uguaglianza; proporzionalità; libera concorrenza. 


\section{LISTA DE ABREVIATURAS E SIGLAS}

Art.

Artigo

$\mathrm{CF}$

Constituição Federal

CIDE

Contribuição de Intervenção no Domínio Econômico

COFINS

Contribuição para o Financiamento da Seguridade Social

CONAMA

Conselho Nacional do Meio Ambiente

CTN

Código Tributário Nacional

$\mathrm{CF} / 1988$

Constituição Federal da República Federativa do Brasil de 1988

CSLL

Contribuição Social sobre o Lucro Líquido

DJ

Diário da Justiça

D.O.U.

Diário Oficial da União

OCDE

Organização de Cooperação e de Desenvolvimento Econômico

CE

Comunidade Europeia

IBAMA

Instituto Brasileiro do Meio Ambiente e Recursos Naturais Renováveis

IPI Imposto sobre Produtos Industrializados

IPTU

Imposto Predial e Territorial Urbano

IR

Imposto sobre a Renda e Proventos de Qualquer Natureza

IRPJ

Imposto sobre a Renda e Proventos de Qualquer Natureza da Pessoa Jurídica

IRPF

Imposto sobre a Renda e Proventos de Qualquer Natureza da Pessoa Física

ISSQN

Imposto sobre serviço de qualquer natureza

$\mathrm{LC}$

Lei Complementar

RT

Revista dos Tribunais

P\&D

Pesquisa e desenvolvimento

PIS

Programa de Integração Social

PEC

Proposta de Emenda Constitucional

STF

Supremo Tribunal Federal

STJ

Superior Tribunal de Justiça

USP

Universidade de São Paulo

VAT

Imposto sobre valor agregado 


\section{SUMÁRIO}

INTRODUÇÃO

\section{O DEBATE DA QUESTÃO AMBIENTAL E A CONSTRUÇÃO DE NOVOS}

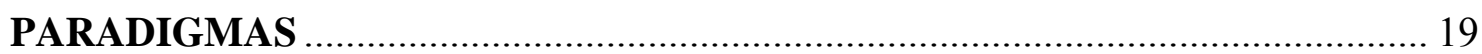

1.1. O caminho sem volta rumo à sustentabilidade...................................................... 19

1.2. Conteúdo e alcance da expressão meio ambiente ................................................. 29

1.3. Evolução da discussão internacional sobre a matéria ambiental ........................... 32

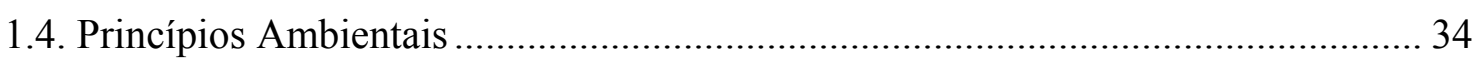

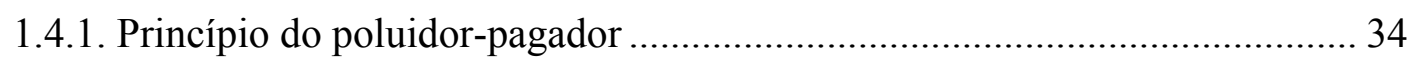

1.4.2. Princípio da prevenção e da precaução ......................................................... 35

1.4.3. Princípio do protetor-recebedor .............................................................. 38

1.5. Tutela constitucional do meio ambiente ........................................................... 41

1.6. Ordem econômica e meio ambiente .................................................................... 44

1.6.1. Formas de atuação estatal na ordem econômica ......................................... 44

1.6.2. Fundamentos para a atuação estatal na economia....................................... 50

1.6.3. A defesa do meio ambiente como princípio da ordem econômica concretizador do desenvolvimento sustentável ....................................................... 53

2. TRIBUTAÇÃO E PROTEÇÃO DO MEIO AMBIENTE ....................................... 65

2.1. A tributação na vida social e econômica do Brasil ................................................ 65

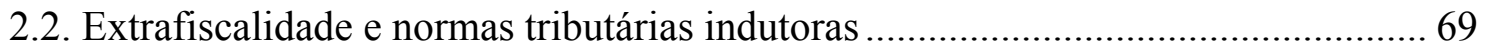

2.3. O tributo como instrumento de defesa do meio ambiente .................................... 76

2.3.1. A experiência brasileira e estrangeira ..................................................... 83

2.3.1.1. Tributos ambientais no Brasil.................................................... 83

2.3.1.2. Tributos ambientais no Direito comparado .................................. 86

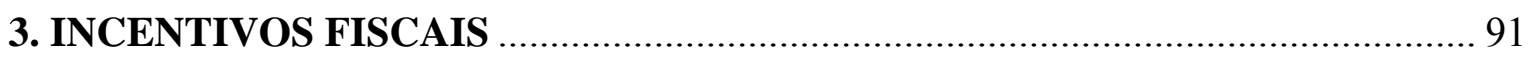

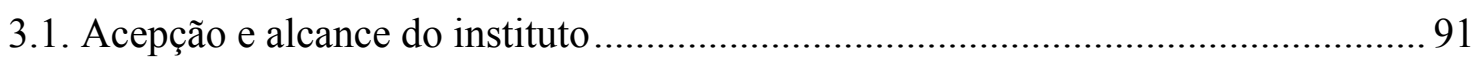

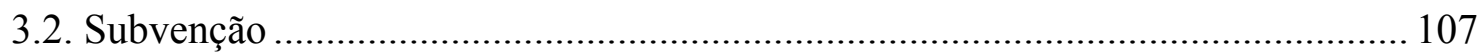

3.3. Incentivos fiscais e algumas formas de manifestação........................................ 110

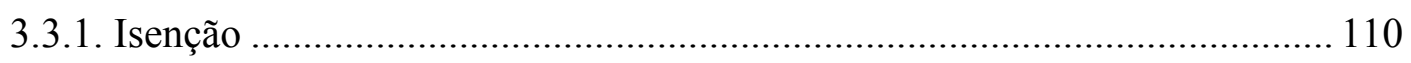

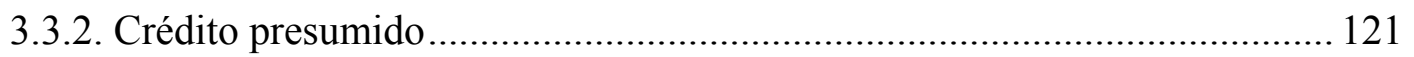

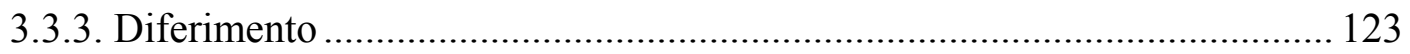

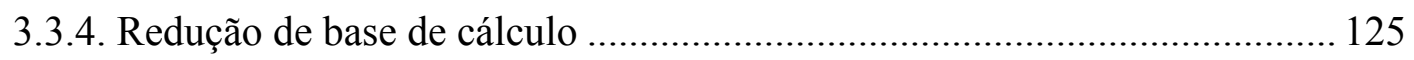

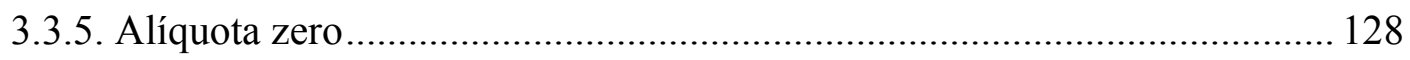




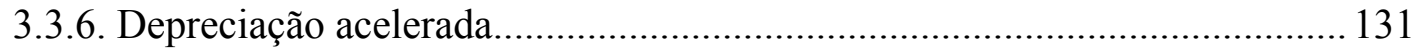

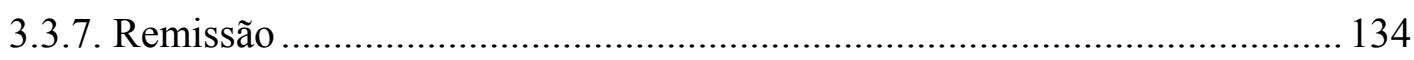

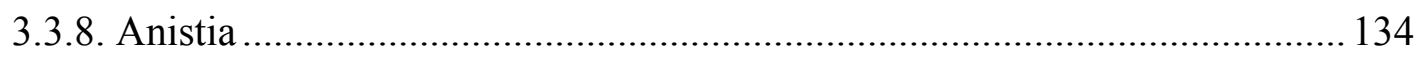

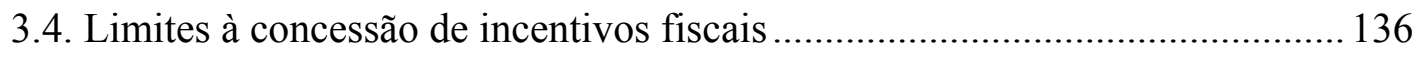

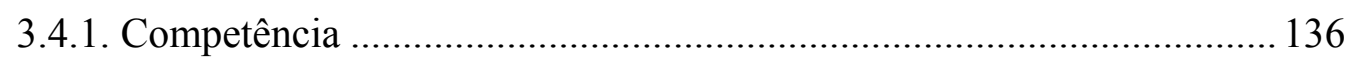

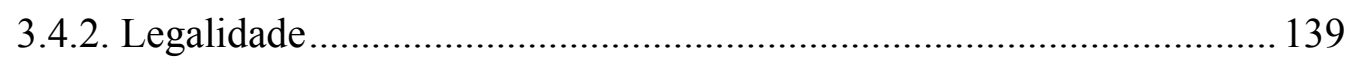

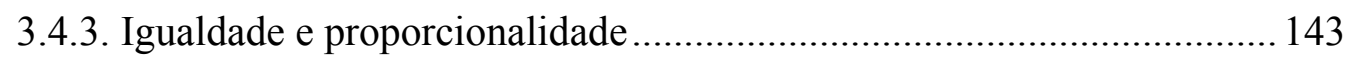

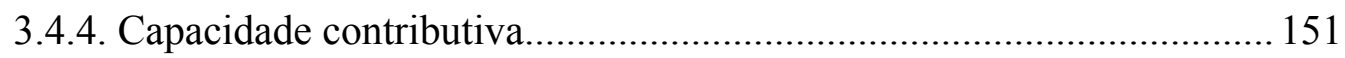

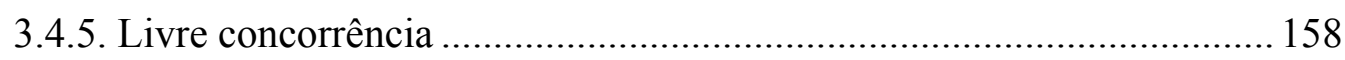

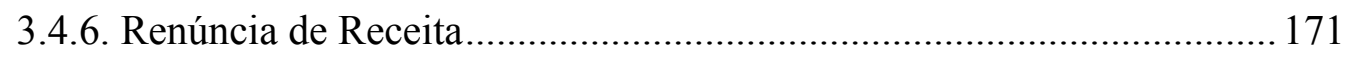

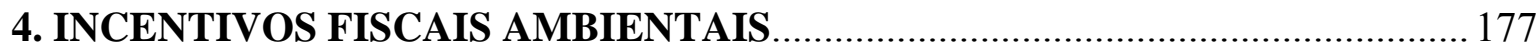

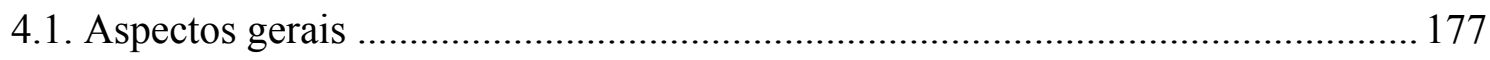

4.1.1. Panorama geral para aplicação dos incentivos fiscais ambientais ........ 177

4.1.2. Princípios ambientais norteadores do instituto .................................... 182

4.1.3. Críticas dirigidas aos incentivos fiscais ambientais............................ 187

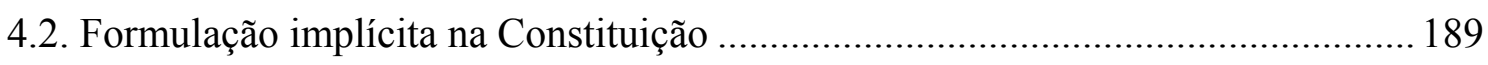

4.3. Incentivos fiscais ambientais no Direito brasileiro e no Direito comparado .......... 193

4.3.1. Incentivos fiscais ambientais no Direito brasileiro ............................... 193

4.3.2. Incentivos fiscais ambientais no Direito comparado .......................... 208

4.4. Limitações à concessão de incentivos fiscais ambientais no Brasil....................... 215

4.4.1. Competência para a instituição de incentivos fiscais ambientais ........ 215

4.4.2. A legalidade aplicada aos incentivos fiscais ambientais...................... 218

4.4.3. Igualdade e proporcionalidade na instituição de incentivos fiscais

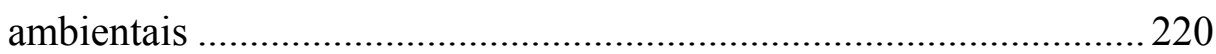

4.4.4. Capacidade contributiva e incentivos fiscais ambientais..................... 236

4.4.5. A questão concorrencial e a concessão de estímulos fiscais ambien-

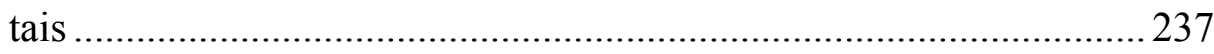

4.4.6. Renúncia de receita e incentivos fiscais ambientais ........................... 245

4.5. Síntese dos parâmetros e limites para a criação de incentivos fiscais ambientais no Brasil

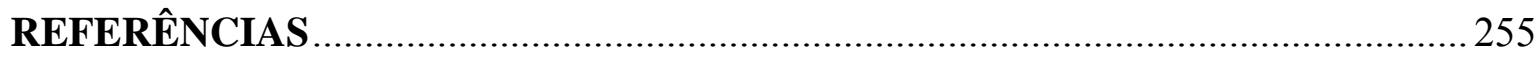




\section{INTRODUÇÃO}

Nos chamados Estados Fiscais, em que a principal fonte de receitas para os cofres públicos provém da arrecadação tributária, é nítida a relação entre a tributação e a conduta social de forma geral.

Portanto, elementar é a constatação de que o tributo pode consubstanciar eficiente instrumento de indução de condutas dos particulares, fomentador da concretização dos mais diversos fins constitucionais.

Tal possibilidade de moldar a norma tributária, de forma a torná-la mais ou menos gravosa diante de determinada situação, decorre do fim extrafiscal do tributo. Consoante se verá, tal fim estará presente sempre que a norma tributária não estiver voltada à função arrecadatória ou simplificadora do tributo, mas predestinada à concretização de desígnios constitucionais.

Neste sentido, a norma tributária instituída, no âmbito da extrafiscalidade, poderá buscar a realização de objetivos econômicos e sociais, tais como a proteção do meio ambiente, o fomento a atividades culturais, desportivas, dentre outras.

Em tal sede, encontram-se os incentivos fiscais, que irão proporcionar um tratamento tributário diferenciado para determinado grupo de contribuintes.

No Brasil, a Constituição Federal previu expressamente o manejo dos incentivos fiscais em dois dispositivos. No art. 151, que determina o tratamento uniforme quanto aos tributos da União, contudo, admite "a concessão de incentivos fiscais destinados a promover o equilíbrio do desenvolvimento socioeconômico entre as diferentes regiões do país". E no art. $227, \S 3^{\circ}$, VI, ao preconizar que o Estado pode estimular a proteção da família, mediante incentivos fiscais ao acolhimento, sob forma de guarda, de criança ou adolescente órfão ou abandonado.

No que concerne à preservação do meio ambiente, o constituinte não previu, de modo específico, a concessão de incentivos fiscais, porém tratou da questão ambiental em vários dispositivos. Assim sendo, a despeito de inexistir previsão específica, é possível extrair da Lei Maior autorização para a instituição de incentivos físcais com viés ambiental. 
Com efeito, o trabalho em tela promoverá o exame dos incentivos fiscais em matéria ambiental no contexto constitucional.

Dar-se-á ênfase ao comando extraído do Capítulo que versa sobre a ordem econômica, art. 170, VI, cuja parte final, introduzida pela Emenda Constitucional n. ${ }^{\circ}$ 42, de 2003, aponta para um tratamento diferenciado de produtos e serviços, bem como dos seus processos de produção, de acordo com o critério de proteção ambiental.

De igual forma, será estudado o que estipula o art. 225 da Lei Maior, plasmado no Título que trata da ordem social, segundo o qual a preservação e a defesa do meio ambiente consubstanciam um dever do Poder Público e da sociedade, sendo o meio ambiente ecologicamente equilibrado um direito das presentes e futuras gerações.

Com efeito, buscando fincar os alicerces que embasam o instituto em apreço, os citados artigos 170 e 225 serão investigados em conjunto com diversos princípios e regramentos constitucionais, dentre eles, os que tratam da questão ambiental em outros Capítulos, bem como aqueles que delimitam o poder de tributar e de conceder incentivos fiscais.

Vale ressaltar que se o tema dos incentivos fiscais alberga grande complexidade, por atrair diversas disciplinas, consubstanciando normas tributárias atreladas à política econômica do Estado e dotadas de reflexos no direito das finanças, aqueles incentivos que se movem com o viés ambiental concentram ainda maior complexidade, porquanto a noção de preservação do meio ambiente atrai múltiplas variáveis. Ademais, a noção de desenvolvimento sustentável, além do aspecto ecológico, perpassa por questões econômicas e sociais.

Deveras, consoante se pretende demonstrar, o entrelaçamento do tema ambiental com os referidos aspectos sociais e econômicos irá refletir na conformação do incentivo fiscal ambiental, porquanto aqueles que fomentarem o desenvolvimento sustentável, no seu tripé econômico, social e ambiental, adquirirão maior compatibilidade com os ditames constitucionais, o que permitirá sejam seu conteúdo e alcance mais amplos do que num modelo focado em apenas uma das mencionadas diretrizes.

Nesta senda, buscar-se-á evidenciar que os incentivos fiscais ambientais, por visarem à efetivação de um desenvolvimento sustentável, figuram como um instrumento ajustado à realidade contemporânea, que já não se satisfaz em incrementar níveis de desenvolvimento econômico e social a qualquer custo, estando atenta a uma evolução em 
tais aspectos compromissada com a continuidade ao longo do tempo da qualidade de vida na sociedade, do crescimento econômico e, em última análise, da vida no planeta.

Noutras palavras, o desafio que se põe na atualidade vai além da promoção de um crescimento econômico e social apartado dos efeitos danosos causados ao meio ambiente, os quais prejudicam a manutenção da vida no planeta. O desafio que se apresenta demanda, a um só tempo, que as medidas interventivas sobre a ordem econômica e social estejam alinhadas com a preservação do meio ambiente e que também as intervenções voltadas à defesa ambiental busquem o incremento econômico e social na maior medida possível.

Disso decorre a necessidade de se tratar conjuntamente os assuntos sociais, econômicos e ecológicos, sob pena de as medidas adotadas não lograrem produzir os efeitos positivos buscados em longo prazo, prestando-se tão só a veicular soluções precárias e emergenciais.

Deveras, os incentivos fiscais ambientais irão representar imposição da própria concepção de crescimento econômico e social a ser perseguida por diversos países na atualidade, que é a concepção de desenvolvimento sustentável. Tal desenvolvimento propõe que se concilie a evolução social, ambiental e econômica, com o intuito de viabilizar um crescimento consistente e, portanto, apto a alcançar as gerações futuras.

Assim, por exemplo, a desoneração de bem de reduzido impacto ambiental que serve de insumo para um bem produzido por uma comunidade de baixa renda irá permitir uma melhoria simultânea dos índices sociais, econômicos e ambientais.

Por seu turno, o incentivo ambiental criado para fomentar a transição de uma economia tradicional ("economia marrom") para uma economia com reduzido impacto ambiental ("economia verde" e "economia de baixo carbono"), por meio de tratamento tributário favorecido a setores produtivos já desenvolvidos, que se propõem a mudar seus bens, serviços e processos produtivos, em função de critérios ambientais, também encontra guarida no ordenamento jurídico, sendo o seu conteúdo examinado no presente trabalho.

Sobreleve-se, todavia, que, se há amplo e incontestável reconhecimento de que os incentivos fiscais podem ser instituídos na seara ambiental, muito se questiona acerca dos seus limites, já que, sob o propósito de defender o meio ambiente, a lei tributária poderá conceder isenções, créditos presumidos, redução de base de cálculo, entre outros estímulos fiscais, sem que tais medidas venham, na prática, representar um efetivo ganho ambiental. 
Além disso, o tratamento tributário diferenciado deverá preservar, na maior medida possível, os outros princípios constitucionais que com ele colidem.

Com efeito, a par da singela constatação de que é legítima a instituição de incentivos fiscais com o intuito de proteger o meio ambiente, há um complexo caminho a ser trilhado na identificação, à luz do ordenamento jurídico nacional, dos limites a que a citada instituição deverá estar adstrita, sob pena de surgirem, sob suas vestes, tratamentos fiscais diferenciados que passam ao largo do objetivo de proteger o meio ambiente, ou ainda, revelam-se incompatíveis com os demais objetivos constitucionais, ferindo, por exemplo, a igualdade e a livre concorrência.

Logo, somente a partir da investigação dos exatos contornos e alcance dos incentivos fiscais torna-se possível verificar quando a criação de incentivos fiscais que favorecem atividades ambientalmente orientadas está em conformidade com o ordenamento jurídico.

Deveras, o estudo em testilha, partindo da premissa de que o atual estágio de degradação ambiental demanda, para reparação dos danos passados e mitigação dos riscos futuros, ações sob várias frentes e sob a liderança de diversos agentes (Estados, indivíduos, empresas e sociedade), e considerando que cabe à ciência do Direito fornecer critérios a serem seguidos na aplicação dos institutos jurídicos disponíveis, adotou como corte epistemológico a elaboração de uma sistematização dos limites e parâmetros para instituição do incentivo fiscal de viés ambiental.

Portanto, uma vez concebido o incentivo fiscal ambiental como um dos diversos instrumentos jurídicos passíveis de ser manejados pelo Poder Público em prol de uma economia mais sustentável e reputando-se necessária a aplicação conjunta (não excludente) de tais instrumentos, não se realizará exame em item específico acerca das vantagens e desvantagens de se adotar esse instituto em detrimento de outros.

Importa destacar que, embora o tema a ser desenvolvido seja atual e possua grande importância e utilidade, sua abordagem pela doutrina, jurisprudência e legislação pátria é bastante escassa.

Ainda mais exíguo se revela o enfrentamento da aludida questão sob a perspectiva das diversas diretrizes constitucionais, que, como já ressaltado, constitui o enfoque que será conferido ao assunto. 
Com efeito, tal carência acaba por transmitir a ideia de que inexistem critérios jurídicos intersubjetivamente controláveis capazes de delimitar a instituição de estímulos fiscais no campo ambiental.

Entretanto, da análise dos princípios e regras extraídos do sistema constitucional pátrio, bem como da doutrina e jurisprudência, vislumbra-se espaço propício à construção de limites jurídicos à criação de incentivos fiscais ecológicos, ajustados às mais variadas vertentes plasmadas no ordenamento jurídico nacional.

De fato, num Estado Democrático de Direito, como o brasileiro, é imperioso que sejam bem delineados os contornos das intervenções de tal ente sobre os direitos e garantias dos contribuintes.

Não é demais pontuar que a criação de tais demarcações afigura-se fundamental à concretização de inúmeros princípios atrelados ao regime democrático, notadamente o princípio da igualdade.

Calha salientar que quando se está no campo dos tributos extrafiscais, em que as normas tributárias se voltam, precipuamente, à indução de condutas concretizadoras dos objetivos constitucionais, a falta de parâmetros jurídicos que estabeleçam, de forma satisfatória, a sua pertinência ao Direito dá margem ao arbítrio. Daí ser imprescindível o desenvolvimento de critérios jurídicos aptos a identificar até que ponto a lei tributária encontra o indispensável amparo jurídico.

Desse modo, a investigação dos mencionados limites jurídicos à criação de incentivos fiscais ecológicos pautar-se-á no sopesamento das mais variadas diretrizes constitucionais por meio do manejo do princípio da proporcionalidade.

Assim sendo, o tema escolhido ganha importância, uma vez que os limites jurídicos que serão formulados poderão servir como instrumento dogmático capaz de contribuir para a compreensão e solução de problemas jurídicos. Nessa esteira, a referida teorização poderá promover maior controle crítico e democrático dos incentivos fiscais criados com intuito de proteger o meio ambiente.

Constata-se, por outro lado, uma carência de obras nacionais que dediquem exclusiva atenção ao tema sob o enfoque ora proposto, uma vez que se verificam, nas obras analisadas, menções pontuais que anunciam a existência de limites à instituição de incentivos fiscais ecológicos, sem, todavia, desenvolver uma abordagem mais profunda. Nesse compasso, a tese a ser elaborada põe em relevo sua importância teórica quando se 
propõe a analisar sistematicamente os limites em foco, com lastro na proporcionalidade, dirigindo ao tema a especial atenção que este exige.

Noutro giro, cumpre esclarecer que, neste cenário de constante interseção de fatores ambientais, econômicos e sociais, o presente estudo, longe de pretender traçar uma fórmula única para a análise e veiculação de incentivos fiscais ambientais no país, irá evidenciar tal multiplicidade de disciplinas e questões que o tema atrai, indicando parâmetros alinhados ao ordenamento jurídico nacional e ao cenário de crise ambiental ora vivenciado.

Deveras, tanto a tributação quanto objetivos econômicos e sociais que o tema envolve devem ser analisados dentro de um contexto histórico. Da mesma maneira, a ideia de preservação ambiental é mutante e oscila ao sabor não só de avanços tecnológicos e dados demográficos, mas também pelos próprios fenômenos da natureza e acidentes provocados pelo homem, os quais podem alterar os limites até então tidos como aceitáveis para a utilização de recursos naturais e emissões poluentes.

Resta, assim, evidente que os elementos estruturantes do tema incentivos fiscais ambientais estão em plena e incessante evolução. Não se almeja, neste trabalho, fincar conclusões que esgotem o assunto; o compromisso é, pois, com a edificação das principais balizas do instituto, a serem erguidas com base em pesquisa que revela dados pertinentes ao contexto ora vivenciado.

Portanto, as diretrizes que serão tracejadas são fruto das premissas de que se vale o estudo em voga, premissas essas que devem ser consideradas à luz da realidade fática e jurídica subjacente. Nada impede, todavia, que outros estudiosos alcancem conclusões distintas, lastreados em pontos de partida diversos ou em momentos históricos diferentes.

Assim, ciente de que se caminha em seara permeada por elementos dinâmicos, abandona-se, desde já, a pretensão de se identificar uma equação rígida e imutável acerca do tema. O conteúdo e alcance que ora se busca esculpir acerca dos limites à concessão de incentivos fiscais ambientais consubstanciam, pois, diretrizes que comportam ponderações concretas para que sua aplicação ao longo do tempo implique o seu objetivo fundamental de realizar o princípio constitucional que determina a defesa do meio ambiente, atrelado, na maior medida possível, ao incremento social e econômico.

Sob tal prisma, inicia-se o presente trabalho expondo-se os maiores dilemas e desafios enfrentados na busca pela migração de uma economia tradicional para a economia de baixo carbono. Ressalta-se a premência de tal mudança de paradigmas e a necessidade 
de haver a união dos indivíduos, das empresas e do Estado nessa missão. Apresentam-se, ainda, os principais princípios ambientais, o debate internacional travado ao longo do tempo e a abordagem constitucional da matéria, com destaque para a análise da defesa do meio ambiente como princípio da ordem econômica.

Nesse compasso, examina-se a forma pela qual o Estado, mediante o manejo de instrumentos econômicos, pode atuar em prol da questão ambiental, seja corrigindo falhas do mercado (quanto aos efeitos externos ou externalidades), seja instituindo políticas públicas que direcionam a economia a concretizar o princípio da defesa do meio ambiente (art. 170, VI, da CF/1988).

Na sequência, expõe-se, no Capítulo 2, um panorama da tributação no país e sua influência nas decisões dos particulares, conferindo-se especial ênfase à função indutora da norma tributária em conexão com a defesa ambiental.

Assim, uma vez desenvolvidos os fundamentos que autorizam o Poder Público a manejar instrumentos econômicos que tem como escopo proteger o meio ambiente, debruça-se, no Capítulo 3, sobre o estudo de um desses veículos, qual seja o incentivo fiscal.

Busca-se, em tal sede, aprofundar o conteúdo do instituto, diferençando-o de categorias com as quais não se confunde, bem como destacando as figuras jurídicas por meio das quais pode manifestar-se, a exemplo de isenção, redução de base de cálculo, diferimento, crédito presumido etc.

São também tracejados limites específicos à sua instituição, investigando-se aspectos como competência, aplicação dos requisitos da Lei de Responsabilidade Fiscal e princípios constitucionais, dentre os quais, legalidade, igualdade, livre concorrência e capacidade contributiva.

Insta registrar que a análise dos princípios constitucionais em pauta será realizada considerando que o instituto em comento tem palco no âmbito da extrafiscalidade, pelo que ganha relevo o princípio da proporcionalidade, como baliza conformadora dos diversos fins, valores e princípios colidentes na criação do incentivo fiscal.

Deveras, revelar-se-á a forma pela qual o princípio da proporcionalidade e seus subprincípios da necessidade, adequação e proporcionalidade em sentido estrito nortearão o exame concreto da compatibilidade entre um tratamento tributário diferenciado e o princípio da isonomia. Ou seja, será avaliado como isenções e demais modalidades de 
desoneração podem ser criadas sem que correspondam a uma medida discriminatória e arbitrária.

Finalmente, no Capítulo 4, dedicado ao exame específico dos incentivos fiscais ambientais, abordar-se-á, de início, os seus aspectos gerais e a sua sede constitucional, para, em seguida, serem retomados os limites desenvolvidos no Capitulo anterior, sendo identificados, em relação a estes, as peculiaridades e complexidades que são próprias do incentivo de cunho fiscal ambiental.

Dentre outros aspectos, investigar-se-á a aplicação dos princípios da legalidade, igualdade, proporcionalidade e livre concorrência, sob a ótica ambiental. Por derradeiro, será apresentada uma sistematização dos parâmetros e limites que devem ser observados para que os incentivos fiscais ambientais sejam concedidos em conformidade com os ditames constitucionais.

Espera-se, assim, que o presente estudo possa, de alguma forma, servir de apoio à elaboração de estímulos fiscais, a serem cunhados, preferencialmente, no bojo de políticas públicas comprometidas em estruturar um desenvolvimento sustentável no país. 


\section{O DEBATE DA QUESTÃo AMBIENTAL E A CONSTRUÇÃo DE NOVOS PARADIGMAS}

\subsection{O caminho sem volta rumo à sustentabilidade}

O fator natureza, conjugado ao fator trabalho e ao fator capital, cria o tripé basilar da atividade econômica. Referida atividade funda-se na extração de elementos oriundos da biosfera, que a ela retornarão após sofrer os mais diversos processos e transformações.

Tradicionalmente, o sistema econômico ${ }^{1}$ era visto como um sistema aberto, no qual se afigurava irrelevante a identificação da origem e do destino dos materiais e energia nele utilizados e dele extraídos ${ }^{2}$. Partia-se da premissa de que os recursos retirados do meio ambiente eram abundantes e os rejeitos produzidos seriam por este absorvidos ou reciclados, de modo a ser possível a transformação em novos fatores de produção.

Entretanto, essa concepção de sistema completamente aberto encontra-se superada. Pensar num sistema aberto ou puramente linear é ter uma visão superficial e restrita à primeira função econômica do meio ambiente natural, que é a de figurar como fornecedor de recursos naturais ao processo produtivo.

Há que se considerar também os rejeitos que serão lançados no ambiente: o dióxido de carbono e demais gases poluentes que são eliminados na atmosfera, o esgoto produzido pelas cidades e indústrias que segue para os rios e oceanos, bem assim os resíduos sólidos que são acumulados nos aterros sanitários ${ }^{3}$. Portanto, a função econômica do meio ambiente natural relativa à assimilação de rejeitos não pode ser ignorada.

Para evidenciar a conexão existente entre os recursos naturais, a produção de bens e seus respectivos refugos, Kenneth Boulding, em 1966, escreveu sua obra The economics of the coming spaceship Earth, na qual trouxe a concepção do Planeta Terra como uma nave espacial. A provocação feita pelo referido autor foi a de imaginar que uma espaçonave que

\footnotetext{
${ }^{1} \mathrm{O}$ sistema econômico pode ser entendido como o conjunto das atividades econômicas de uma determinada sociedade ou região. Numa conceituação mais técnica, seria um conjunto harmônico de instituições, por meio das quais as questões econômicas são resolvidas e decisões são tomadas. Caracteriza-se de acordo com a relação entre os elementos da produção.

${ }^{2}$ NUSDEO, Fábio. Curso de economia: introdução ao direito econômico. 6. ed. rev. e atual. São Paulo: RT, 2010. p. 369.

${ }^{3}$ PIERCE, David W.; TURNER. R. Kerry. Economics of natural resources and the environment. Maryland: The Johns Hopkins University Press, 1990. p. 36.
} 
segue para uma longa viagem apenas estará suprida dos recursos que foram postos antes da decolagem e, caso não haja a reciclagem da água e demais materiais, os tripulantes terão sua expectativa de vida reduzida.

Tal comparação do Planeta Terra com uma espaçonave ilustra bem o fato de que tanto o sistema ambiental quanto o sistema econômico possuem ligações circulares e fechadas ${ }^{4}$.

Contrapondo-se à referida concepção, Boulding denomina de economia cowboy uma economia regida pela ideia de que o homem pode sempre seguir indefinidamente adiante, com novas terras e cenários. Tal ilustração representa um sistema aberto, em que seria possível viver num eterno desbravamento.

Todavia, a citada ideia de economia cowboy não condiz com o cenário real (fica relegada ao mundo da ilustração), ante o extraordinário crescimento econômico, a explosão

\footnotetext{
${ }^{4}$ É a concepção de sistema fechado que irá evidenciar, de forma nítida, os limites da interação entre os sistemas econômico e ambiental e sua ligação circular. Retomando-se a analogia feita com uma espaçonave, verifica-se que nesta não há reservatórios livres, seja de novos produtos, seja para disposição dos produtos já utilizados, sendo necessário estar atento ao estoque de materiais e à forma de reaproveitálos e descartá-los após a sua utilização. Sob tal prisma, passa-se a indicar noções e premissas extraídas da economia ambiental para uma melhor compreensão dos mencionados limites:

Primeiramente, observa-se que nem todos os materiais que sofrem transformação pelo sistema econômico poderão ser reaproveitados. Há materiais que não podem ser reciclados, seja por não haver ainda conhecimento científico para tanto, seja pelo fato de os altos custos não justificarem. Tais produtos, desprovidos de serventia e tidos como rejeitos, serão parcialmente absorvidos pelo meio ambiente natural. Entretanto, haverá uma parcela do refugo que não será assimilada, consubstanciando tal parcela o primeiro limitador a ser considerado.

Outra limitação repousa na questão da disponibilidade dos recursos naturais, que não podem ser vistos como inesgotáveis. Tanto os recursos renováveis como os recursos não renováveis tornam-se escassos diante de uma demanda desordenada. Ou seja, a extração superior à capacidade de regeneração dos primeiros ou superior ao estoque existente dos segundos leva ao fim de ambos.

Em relação à energia, sua limitação é patente, já que se trata de recurso que invariavelmente sofre dissipação, via calor, para o ambiente, não podendo ser reciclada.

José Eli da Veiga sintetiza a questão: "A quantidade de matéria e energia incorporada aos bens finais é menor que a contida nos recursos utilizados na sua produção. Em outras palavras, uma parte da energia e do material transformados se torna imediatamente resíduo. Isso significa que não se pode alcançar uma eficiência produtiva total. Evidentemente, a quantidade desperdiçada no processo depende do estado da tecnologia de produção em dado momento. Avanços na tecnologia de produção significam menos desperdício, com maior proporção de material e energia de baixa entropia incorporada aos bens finais.

Existe, de fato, o potencial para que mais bens possam ser produzidos a partir de uma mesma quantidade de recursos energéticos e materiais. Mas uma vez alcançado o limite termodinâmico da eficiência, a produção fica totalmente dependente da existência do provedor de recursos adicionais, o capital natural. Conforme o processo produtivo se aproxima de tal limite, a dificuldade e o custo de cada avanço tecnológico aumentam. A rigor, energia e matéria aproveitáveis são os únicos insumos do processo econômico" (VEIGA, José Eli da. Economia em transição. In: ALMEIDA, Fernando (Org.). Desenvolvimento sustentável 2012-2050: visão, rumos e contradição. Rio de Janeiro: Elsevier, 2012. p. 7-8).
} 
demográfica e o incremento do consumo experimentado sobremodo a partir da Revolução Industrial $^{5}$.

Tais situações foram acirradas no pós-guerra, vindo à tona, de forma irreversível, o debate acerca da questão da finitude dos bens ambientais e da necessidade de haver o seu reaproveitamento.

Sob tal perspectiva, defende o professor Fábio Nusdeo ${ }^{6}$ :

[...] não é mais possível ignorar a origem, as transformações e o destino dos materiais e da energia utilizados pelo homem em sua atividade econômica, seja de produção, seja de consumo. Isso porque tanto a origem quanto o destino estão profundamente imbricados nesse conjunto de atividades e nas transformações por ele impostas, passando a condicionar o sistema como um todo.

E arremata o aludido jurista:

A passagem de um sistema aberto para um sistema fechado implica, é claro, uma mudança drástica de perspectiva pela qual o homem vê a si próprio e ao universo ao seu redor. A mentalidade e a linha condutora de suas ações têm necessariamente de passar por funda revisão, porque essas ações passam a ter influência no conjunto de elementos nos quais ele se insere.

$\mathrm{O}$ afastamento da ideia de que os sistemas econômico e ambiental são abertos e lineares e o reconhecimento de que estes são fechados, afigurando-se intrínseca a relação entre a extração dos recursos naturais e o descarte de resíduos, remete ao questionamento acerca de até quando o meio ambiente natural será capaz de responder às demandas do sistema econômico.

\footnotetext{
5 "O aparecimento da máquina movida a vapor foi o nascimento do sistema fabril em grande escala [...]. O sistema fabril, com sua organização eficiente em grande escala e sua divisão de trabalho, representou um aumento tremendo na produção. As mercadorias saíam das fábricas num ritmo intenso. Esse aumento da produção foi em parte provocado pelo capital, abrindo caminho na direção dos lucros. Foi, em parte, uma resposta ao aumento da procura. A abertura de mercados das terras recém-descobertas foi uma causa importante desse aumento. Houve outra. As mercadorias produzidas nas fábricas encontravam também um mercado interno simultaneamente com o mercado externo. Isso devido ao crescimento da população na própria Inglaterra [...].

E tal como houve melhoramento nas ferramentas e máquinas usadas na indústria, assim o século XVIII viu novos e melhores arados, enxadas etc., usados na Inglaterra.

$\mathrm{O}$ crescimento da população, as revoluções no transporte, agricultura e indústria - tudo isso estava correlacionado. Agiam e reagiam mutuamente. Eram forças abrindo um mundo novo" (HUBERMAN, Leo. História da riqueza do homem. Rio de Janeiro: LTC, 1986. p. 172-174).

${ }^{6}$ NUSDEO, Fábio. Op. cit., p. 369.
} 
De fato, busca-se identificar a escala em que os intercâmbios entre o meio ambiente e a economia viabilizam a existência equilibrada de ambos. O meio ambiente deve ter condições não só de manter, mas de incrementar, os níveis de satisfação e o padrão de vida em vigor. O sustento da economia esperado é o de longo prazo, sem a redução do bemestar já alcançado (no campo da saúde, da educação, da alimentação, da cultura etc.). O escopo não é manter os recursos naturais com a subsequente redução da qualidade de vida atingida, de modo que se afigura um grande desafio a ser trilhado.

Deveras, a Comissão Mundial sobre Meio Ambiente e Desenvolvimento da Organização das Nações Unidas, por intermédio do documento Our Common Future, de 1987, também conhecido como Relatório Brundtland, definiu que o desenvolvimento sustentável seria aquele "que satisfaz as necessidades presentes, sem comprometer a capacidade das gerações futuras de suprir suas próprias necessidades"7.

Considerando as funções do sistema ambiental (fonte direta de utilidade, fornecedor de matérias-primas e receptor de materiais danosos), estabelecem-se algumas regras que contribuem para que tais funções possam ser mantidas ${ }^{8}$ :

1) Uso de recursos renováveis em montante inferior à capacidade da sua renovação.

2) Manutenção do fluxo de resíduos no mesmo nível ou abaixo da capacidade de absorção deste pelo meio ambiente.

Noutro aspecto, uma vez que os recursos não renováveis, em algum momento, chegarão ao fim, duas outras formulações devem ser acrescentadas ${ }^{9}$ :

1) O esgotamento dos recursos não renováveis deverá ser compensado por um aumento de estoque de recursos renováveis.

2) O padrão de vida deve ser mantido com a redução do uso de recursos naturais.

\footnotetext{
${ }^{7}$ Marcos Nobre alerta para o fato de que o conceito de desenvolvimento sustentável: "surgiu não só como noção fadada a produzir consenso, mas também como um enigma a ser criticado por sua vaguidão, imprecisão e caráter contraditório. De fato, o que mais se viu (e ainda se vê) desde a publicação do livro Our common future - o chamado 'Relatório Brundtlan', de 1987 - foi a busca por uma 'definição' de DS, o anseio pela resposta final sobre o que seja tal noção a que quase ninguém parece se opor" (NOBRE, Marcos. Desenvolvimento sustentável: origens e significado atual. In: ——; AMAZONAS, Maurício de Carvalho (Org.). Desenvolvimento sustentável: a institucionalização de um conceito. Brasília: Ed. Ibama, 2002. p. 25).

${ }^{8}$ PIERCE, David W.; TURNER. R. Kerry. Op. cit., p. 44. As regras acima postas referem-se aos recursos renováveis e não levam em consideração a possibilidade de haver um incremento na capacidade de regeneração dos recursos e de assimilação dos rejeitos, por força da utilização de fertilizantes e outros meios químicos.

${ }^{9}$ PIERCE, David W.; TURNER. R. Kerry. Op. cit., p. 45.
} 
Em suma, tais diretrizes propõem a preservação dos estoques de recursos naturais por meio da: i) utilização dos recursos renováveis em patamar inferior ou equivalente à capacidade que o meio ambiente tem de regenerá-los ou de absorver os dejetos deles decorrentes, ii) substituição dos recursos não renováveis pelos renováveis e iii) redução da necessidade de recursos naturais para manutenção do mesmo padrão de vida.

Vale notar que os mencionados vetores constituem apenas uma parte da problemática relativa à identificação de caminhos e medidas para se alcançar um desenvolvimento sustentável. Prestam-se, pois, a introduzir a questão da coexistência, por longo prazo, dos sistemas econômico e ambiental.

Importante notar que, nesta tormentosa equação, diversos outros elementos devem ser considerados. Dentre eles, o crescimento demográfico e as limitações dos avanços tecnológicos. Isto porque é possível que se alcance significativa evolução científica, apta a incrementar as condições de vida com a redução do consumo dos ativos ambientais, porém o aumento exagerado da população pode vir a suplantar os ganhos ambientais auferidos.

Some-se a tais variantes a própria dificuldade em se contabilizar os estoques de recursos naturais existentes, que, inclusive, podem sofrer grandes oscilações, seja diante da descoberta de novas fontes (jazidas, poços de petróleo etc.), seja por força de catástrofes que reduzem o montante considerado (acidentes provocados pela ação humana ou natural).

Muito embora, nessa temática, ainda não se tenha logrado firmar indicadores absolutos, muito menos soluções definitivas, o fato é que já se chegou a um consenso mundial $^{10}$ no sentido de que a relação entre a economia e o meio ambiente deve adquirir foros de centralidade, sendo improrrogável que se repense a forma de produção e de consumo que vem sendo praticada desde a Revolução Industrial.

Com efeito, em pouco mais de duzentos anos, o império do baixo custo, alto consumo e produção em escala fez com que o planeta tivesse seus recursos naturais

\footnotetext{
${ }^{10}$ Até por força da pressão ambiental corporificada na elevação da temperatura no planeta e no acirramento das calamidades públicas decorrentes das intempéries da natureza, já há um entendimento dos mais variados países no sentido de que a questão ambiental não pode mais ser ignorada, devendo ser trazida para o centro dos debates atuais. Entretanto, a dificuldade que se põe é identificar soluções efetivas diante de realidades tão antagônicas. É inevitável que medidas adotadas para preservar o meio ambiente colidam com os interesses de particulares, de grupos sociais existentes num país. Em termos mundiais, os países desenvolvidos defendem que a crise econômica vivenciada impede a implementação de medidas em larga escala, pois atingiriam a economia que ora se vê fragilizada. Por seu turno, as nações ditas em desenvolvimento, que revelam crescimento, resistem a adotar qualquer tipo de medida que venha a prejudicar a economia em expansão.
} 
avidamente consumidos e fosse alvo de desenfreada poluição e transformações irreversíveis.

O aquecimento global, a chuva ácida, a destruição da camada de ozônio, o desmatamento de florestas, a extinção de espécies, as inundações, as estiagens e a elevação do nível dos oceanos, dentre outros resultados nefastos que vêm sendo produzidos, já afetam diretamente a vida no planeta.

A criação de novos contornos para a produção, circulação e consumo de bens, portanto, torna-se uma imposição do próprio cenário atual, cujas tragédias vivenciadas são prenúncios de um iminente colapso.

Cunhada em 2000, após 10 anos de discussões por todo o mundo, a "Carta da Terra" consubstancia declaração de princípios éticos fundamentais para a criação, na atualidade, de uma sociedade sustentável. Tal documento, subscrito por mais de 4.500 organizações, incluindo inúmeros organismos governamentais e organizações internacionais, denuncia o estado atual de grande degradação do planeta, conclamando a todos a adotar uma postura ativa diante desta situação. Ressalte-se um trecho do texto em foco:

Os padrões dominantes de produção e consumo estão causando devastação ambiental, esgotamento dos recursos e uma massiva extinção de espécies. Comunidades estão sendo arruinadas. Os benefícios do desenvolvimento não estão sendo divididos equitativamente e a diferença entre ricos e pobres está aumentando. A injustiça, a pobreza, a ignorância e os conflitos violentos têm aumentado e são causas de grande sofrimento. $\mathrm{O}$ crescimento sem precedentes da população humana tem sobrecarregado os sistemas ecológico e social. As bases da segurança global estão ameaçadas. Essas tendências são perigosas, mas não inevitáveis [...]

Como nunca antes na História, o destino comum nos conclama a buscar um novo começo. Tal renovação é a promessa destes princípios da Carta da Terra. Para cumprir esta promessa, temos de nos comprometer a adotar e promover os valores e objetivos da Carta.

Isto requer uma mudança na mente e no coração. Requer um novo sentido de interdependência global e de responsabilidade universal. Devemos desenvolver e aplicar com imaginação a visão de um modo de vida sustentável nos níveis local, nacional, regional e global [...].

Apesar de inferiores ao que propõe o documento acima em destaque, não se podem ignorar as adaptações realizadas pelo setor produtivo no que se refere à diminuição da poluição local, à redução das emissões em determinadas áreas, à eficiência energética e ao 
maior e melhor aproveitamento dos recursos naturais. As mudanças quanto ao consumo, todavia, é que ainda não experimentaram avanços expressivos.

A reformulação de toda uma concepção de desenvolvimento econômico, antes pouco compromissada com a questão ambiental, não é tarefa simples. Os desafios da sustentabilidade, que não se limitam à questão ambiental, mas se estendem ao campo econômico e social, pressupõem mudanças estruturais.

Os governos e a sociedade, nos seus mais variados níveis, estão sendo conscientizados e até obrigados legalmente a contribuir com as ideias e inovações. As empresas, um dos principais atores sociais, buscam reverter a ideia de que o seu desenvolvimento ocorre à custa da sociedade. Pretendem, ainda, identificar um caminho harmônico entre o social, o ambiental e o econômico.

Tais noções, longe de ser consensuais, encontram forte resistência de setores que se sentem ameaçados com os novos paradigmas e ainda não se encontram aptos a uma adaptação.

Diante de todo esse impasse, afigura-se fundamental trazer para o seio da discussão o papel da tecnologia. De fato, pela lógica ora em vigor, a saída mais conveniente e cômoda para um início de equacionamento da questão e tentativa de migração para uma economia verde ${ }^{11}$ é atribuir aos avanços tecnológicos o desafio de identificar substitutos às matérias-primas não renováveis, criar métodos de reciclagem, tratamento e reutilização dos rejeitos decorrentes das transformações dos insumos usados pelo sistema econômico, com o menor custo possível. Sobre a questão, Ricardo Abramovay pontifica ${ }^{12}$ :

$\mathrm{Na}$ fronteira do avanço tecnológico contemporâneo estão tecnologias que permitem reduzir de forma crescente a intensidade energética da produção industrial, dos transportes e do próprio consumo doméstico. Friedman mostra o avanço das redes elétricas inteligentes (smart grids), em que as empresas fornecedoras serão remuneradas não em função da ampliação do consumo dos seus clientes, mas, ao contrário, por sua capacidade de promover sua redução. Ao mesmo tempo, os próprios aparelhos que usam energia elétrica são e serão cada vez mais concebidos para que usem a menor quantidade possível de energia e menos materiais: esta é a dimensão mais relevante das invenções e das descobertas industriais recentes.

\footnotetext{
11 "Economia verde é a economia que resulta em maior bem-estar humano e igualdade social, ao mesmo tempo que reduz substancialmente a escassez ambiental e ecológica" - PNUMA. Towards a green economy: pathways to sustainable development and poverty eradication - a synthesis for policy makers, 2011. Disponível em: <www.unep.org/greeneconomy>. Acesso em: 22 nov. 2012.

12 ABRAMOVAY, Ricardo. Desenvolvimento sustentável: qual a estratégia para o Brasil? Revista Novos Estudos, São Paulo, n. 87, p. 109, jul. 2010.
} 
O objetivo é alcançar, por intermédio da tecnologia, um padrão de produção e consumo com reduzidos impactos ambientais, acompanhado da minimização de custos, do incremento de receitas, da potencialização da marca e da melhoria na gestão de riscos.

A mudança de paradigma tecnológico requer muitas inovações; portanto, até que se consiga atingir os mesmos níveis e resultados da produção convencional, investimentos, às vezes sem retorno, precisam ser realizados.

As rupturas tecnológicas rumo à produção e ao consumo sustentável demandam custos e despesas adicionais não verificados nos moldes de produção anterior, que funcionavam, em tese, de modo estável. De fato, para que os investimentos em novas tecnologias não se tornem insustentáveis, a sociedade civil, as corporações e os governos devem estar engajados. Um passo adiante, em temos de sustentabilidade, não pode ser dado por apenas um dos citados atores, sendo imperioso que se torne objetivo comum de todos.

Isto porque, numa economia calcada em resultados imediatos, que tem como tônica a incessante superação de metas no menor espaço de tempo possível, especialmente em relação à obtenção de lucro, destoa da lógica posta que um dos atores tome, de forma isolada, decisões focadas em sustentabilidade, em prejuízo dos fatores econômicos, por exclusivo interesse em preservar os ativos ambientais para as gerações futuras.

Assim, uma vez que o cenário econômico atual não é propício a comportamentos ambientalmente orientados sem o correlato retorno econômico em curto prazo, torna-se urgente a criação de mecanismos responsáveis por conferir a devida ênfase e valoração que a questão ambiental requer.

Caso contrário, governos e líderes empresariais, por exemplo, que precisam demonstrar resultados financeiros positivos e alcançar as demais metas num período curto de tempo, continuarão a relegar para segundo plano os ganhos ambientais de longo prazo ${ }^{13}$.

\footnotetext{
${ }^{13}$ Sobre essa questão, registre-se a ponderação de Ernst Ligteringen: "Há quem veja os seres humanos como, fundamentalmente, pensadores imediatistas. Como resultado de processos evolutivos, reforçados pelos mecanismos de mercado expostos anteriormente, que distorcem a realidade, somos incapazes de agir de acordo com nossos interesses de longo prazo. Se isso for, de fato, verdade, continuaremos agindo como sempre fizemos, o mundo testemunhará outras reuniões de ministros do meio ambiente em convenção sobre o clima ou biodiversidade enquanto chefes de Estado e ministros das finanças se reunirão separadamente para discutir a economia em outras convenções.

Esse mesmo viés da manutenção da atual forma de fazer negócios continuará em vigor nas salas do conselho. O hoje é real, o amanhã é ficção. As empresas terão seus defensores da responsabilidade social corporativa para discutir seu respeito pela natureza e o compromisso com as pessoas e o esforço para demonstrar a validade de um argumento comercial que proporcionará retorno positivo no curto prazo. Entretanto, em sua maior parte, as decisões corporativas continuarão impulsionadas por números trimestrais
} 
Vale registrar que, atualmente, as grandes empresas, especialmente as de capital aberto, já vêm elaborando relatórios integrados que abrangem não só os aspectos fiscais e contábeis, mas também abarcam informações sobre as questões relativas ao meio ambiente. São indicados, por exemplo, dados relacionados: à política ambiental (compromisso, abrangência e divulgação; comunicação com as partes interessadas, sistema de gestão); ao desempenho (consumo de recursos ambientais, emissões e resíduos, seguro ambiental); e ao cumprimento legal (área de conservação permanente, reserva legal, passivos ambientais, processos administrativos e judiciais).

Tais dados contêm indícios sobre riscos e oportunidades do negócio, pelo que os investidores vêm demonstrando interesse sobre o desempenho das companhias também em termos de sustentabilidade. De fato, uma gestão falha em tal seara poderá causar acidentes, cujas consequências impactarão negativamente sobre o valor das ações.

Há uma tendência mundial em tornar obrigatórios para as empresas abertas os relatórios integrados. A legislação francesa passará a exigir que todas as empresas, públicas e privadas, com 500 ou mais empregados, incluam informações de tal natureza em seu relatório anual, com a correlata garantia sobre os dados transmitidos ${ }^{14}$.

Todavia, a velocidade em que tais exigências governamentais e de mercado vêm sendo introduzidos ainda se encontra muito aquém do necessário para a efetiva transformação do padrão de produção e consumo.

Para potencializar tal evolução, seria importante a criação de uma métrica capaz de agregar valor às empresas, cujo relatório ambiental revelasse índices positivos, bem como

para sustentar preço da ação no curto prazo. Em suma, não se juntam os pontos, não se estabelecem as conexões entre eles.

[...] A visão de uma Economia Verde transcende às perspectivas específicas de cada empresa e precisa ser gerada pelos responsáveis pela elaboração de políticas em nível macro. O governo tem uma função promocional e de liderança de fundamental importância a desempenhar aqui. Políticas coerentes ajudarão o florescimento de negócios sustentáveis criando as condições adequadas ao desenvolvimento de uma economia sustentável definitiva [...]" (LIGTERINGEN, Ernst. Caminhando e conversando: stakeholders, juntos, a caminho de uma economia verde. In: ALMEIDA, Fernando (Org.). Desenvolvimento sustentável 2012-2050: visão, rumos e contradição. Rio de Janeiro: Elsevier, 2012. p. 19-26).

14 “Em 28 de dezembro de 2011, a BM\&FBovespa anunciou a recomendação de que, a partir de 2012, todas as empresas listadas na bolsa precisariam publicar um relatório de sustentabilidade ou explicar por que não o fazem.

Um relatório de sustentabilidade fornece aos acionistas e a outras partes interessadas informações sobre o desempenho e sobre as políticas ambientais, sociais e de governança da companhia (ESG).

Ao anunciar tal recomendação, a BM\&FBovespa aderiu à Bolsa de Valores de Johannesburgo, na África do Sul, mostrando liderança ao promover a transparência sobre como operações de uma empresa afetam a sociedade" (AMAR, Jorge; ECCLES, Robert G.; SERAFEIM, George. Brasil: uma sociedade sustentável. Disponível em: <http://www.ideiasustentavel.com.br/2012/06/brasil-uma-sociedade-sustentavel/>. Acesso em: 29 ago. 2012). 
adotar mecanismos que estimulassem o crescimento de tais companhias. Afinal de contas, quanto maiores as vantagens em se optar pela redução dos impactos ambientais, mais célere será a incorporação de condutas que apontam para esse sentido.

Deveras, no atual estágio do mercado, é pouco provável que um investidor deixe de investir em empresa extremamente lucrativa para investir em outra menos lucrativa, apenas pelo fato de esta última possuir uma política de gestão ambiental mais amadurecida. Contudo, se aqueles que investissem em empresas ambientalmente orientadas obtivessem algum estímulo econômico-financeiro adicional, essa situação certamente se modificaria.

As companhias comprometidas em incrementar ambos os desempenhos (sustentabilidade e financeiro) investem em inovação, na tentativa de desenvolver modelos de negócio, processos e produtos mais sustentáveis, muito embora estes possam não trazer, de imediato, o resultado financeiro como contrapartida.

Assim, com o incentivo de todos os atores sociais, os investimentos em sustentabilidade poderiam ser rapidamente transformados em bons resultados, não só de cunho ambiental, como também social e econômico. No âmbito nacional, a ideia de o Brasil incentivar mudanças e avanços tecnológicos voltados a um crescimento sustentável, além de trazer benefícios concretos para a população, que viverá num ambiente mais "saudável”, também agregará valor aos produtos e serviços aqui desenvolvidos, já que a tendência é se buscar bens e serviços social e ambientalmente responsáveis.

Consoante se demonstrará com mais vagar adiante, é objetivo constitucional que o tripé da sustentabilidade seja efetivado na maior medida possível, sendo reduzidas as desigualdades sociais e os impactos ao meio ambiente, em paralelo a um consistente desenvolvimento econômico.

Restará evidenciado, ainda, que a Lei Maior atribuiu responsabilidade ao Poder Público para estimular a redução de impacto ambiental, pelo que tal ente poderá valer-se de diversos instrumentos, dentre eles o incentivo fiscal, para fomentar a realização de investimentos em mitigação de passivos ambientais, bem como visando estimular a demanda por produtos e serviços verdes. 


\subsection{Conteúdo e alcance da expressão meio ambiente}

Em que pese ser bastante difundida, a expressão meio ambiente afigura-se deveras imprecisa e até redundante, afinal, meio e ambiente são palavras que se referem a lugar, órbita, âmbito em que se vive, e, portanto, possuem sentidos semelhantes. Tanto é assim que, no dicionário, uma palavra remete à outra.

Ao definir a acepção jurídica de meio ambiente, Eros Roberto Grau ${ }^{15}$ sustenta que se refere a "todos os elementos, sejam eles naturais, artificiais e culturais do espaço em que o homem vive, os quais interferem na sua qualidade de vida, assim como todas as interações desses elementos".

Nota-se que, para o citado jurista, a conceituação de meio ambiente afigura-se bastante antropocêntrica, porquanto seus elementos giram em torno da vida humana.

Reforçando o caráter antropocêntrico da questão ambiental, Ricardo Lobo Torres ${ }^{16}$ defende que é na pessoa humana que repousa o direito inalienável de "viver em ambiente sadio e de ver por todos respeitada a natureza que a cerca".

Ao tratar do conceito de meio ambiente, Cristiane Derani ${ }^{17}$ defende que este decorre da relação que as sociedades contemporâneas possuem com a natureza, em que esta é o recurso natural (matéria a ser apropriada) e o homem consubstancia o sujeito apartado do objeto a ser apropriado. O homem não é mais natureza, e o meio ambiente seria todo o entorno que envolve esse solitário sujeito. O meio ambiente abarca, portanto, a natureza bruta, em sua forma primitiva, acrescida de todas as transformações nela ocorridas.

Adverte a mencionada jurista que, apesar de o homem não figurar no conceito de meio ambiente, isso não significa que sua acepção possui cunho menos antropocêntrico. Sua formulação revela exatamente a subordinação e a dominação do "mundo exterior", que é objeto de ação do "eu ativo".

\footnotetext{
15 GRAU, Eros Roberto. Equilíbrio ambiental no espaço urbano. Revista da Procuradoria-Geral do Município de Porto Alegre, Porto Alegre, n. 8, p. 68, mar. 1995.

16 TORRES, Ricardo Lobo. Valores e princípios no direito tributário ambiental. In: TÔRRES, Heleno Taveira (Org.). Direito tributário ambiental. São Paulo: Malheiros, 2005. p. 24.

${ }^{17}$ DERANI, Cristiane. Direito ambiental econômico. 3. ed. São Paulo: Saraiva, 2009. p. 52-53.
} 
Por sua vez, cumpre consignar que a Resolução n. ${ }^{0}$ 306/2002 do Conselho Nacional do Meio Ambiente - CONAMA, na esteira do disposto pela Lei n. ${ }^{\circ}$ 6.938/1982 ${ }^{18}$, ao inserir a proteção à vida na conceituação de meio ambiente, não fez qualquer especificação em relação à vida humana. Ressalte-se a dicção da norma em comento:

Meio ambiente: conjunto de condições, leis, influência e interações de ordem física, química, biológica, social, cultural e urbanística, que permite, abriga e rege a vida em todas as suas formas.

Estabelecida a acepção de meio ambiente, passa-se a abordar a sua classificação. Tradicionalmente, o meio ambiente costuma ser dividido em quatro categorias, compostas por bens ambientais. São elas: o meio ambiente natural, artificial, cultural e laboral.

a) O meio ambiente natural abarca a fauna, flora, ar, água e solo.

b) O meio ambiente artificial se refere às edificações urbanas (praças, prédios, ruas e parques).

c) O meio ambiente cultural equivale aos patrimônios histórico, artístico paisagístico e turístico, que, embora indubitavelmente sejam artificiais, configuram-se como culturais pelo valor peculiar que detêm. Assim, por exemplo, o Forte de Copacabana no Rio de Janeiro, pelo seu significado valorativo, enquadra-se como bem ambiental cultural.

d) O meio ambiente do trabalho corresponde ao local onde as pessoas executam suas atividades laborais, o qual deve ser salubre e desprovido de aspectos que tragam prejuízos à integridade física e psíquica dos profissionais, tais como excesso de ruído, radiação, temperaturas inadequadas etc.

A classificação ora em foco, além de possuir indiscutível fim didático, revela-se importante para a assimilação e identificação dos regimes jurídicos que devem ser aplicados a cada categoria de bens ambientais, pois são necessariamente diversos. De fato, o tratamento jurídico conferido à fauna deve ser diferente daquele dispensado a um monumento histórico, por exemplo.

Todavia, a crítica que se faz à classificação do meio ambiente é a de que segmenta uma realidade que, por sua própria natureza, é una. Ora, o ambiente é um só, estando os

\footnotetext{
${ }^{18}$ A referida lei ordinária federal dispõe sobre a política nacional do meio ambiente.
} 
elementos naturais e artificiais sobrepostos. Não há como pretender fazer uma análise do meio ambiente de forma estanque.

É impossível mensurar, em termos absolutos, qual dos bens ambientais é mais relevante para o homem, visto que, conjuntamente, exercem influência sobre a vida em todas as suas formas.

A despeito de o meio ambiente ser uno, havendo o inequívoco entrelaçamento das categorias acima delineadas, o presente estudo, que pretende analisar parâmetros para a concessão de incentivos fiscais, terá como foco o exame de estímulos ambientais atrelados ao meio ambiente natural, abrangendo, assim, o fomento de condutas que se movem em direção da proteção da fauna, flora, ar, água e solo.

Destarte, para fins deste trabalho, a utilização da expressão meio ambiente deverá ser compreendida como o meio ambiente natural.

Ressalte-se que as questões atreladas aos elementos que compõem o meio ambiente natural assumem dimensão global, haja vista, por exemplo, que a poluição não fica restrita ao território em que ela tem teve início. A emissão desenfreada de gases que produzem efeito estufa aumenta a temperatura em todo o planeta e acirra o processo de desertificação. Por sua vez, o derretimento das calotas polares redunda na elevação do nível dos oceanos, provocando inundações por todo o mundo. E, assim, os trágicos desdobramentos em cadeia vão sendo constatados.

Fernando Facury Scaff e Lise Tupiassu ${ }^{19}$ exemplificam essa situação ao mencionarem que uma emissão de determinado poluente ocorrida no Peru pode chegar até Marajó, no Brasil, em vista do curso do rio Amazonas.

Destarte, as medidas que devem ser tomadas com o intuito de solucionar tais problemas que assolam o mundo não podem restringir-se a ações domésticas realizadas em cada país, mas devem ser consideradas num cenário internacionalizado, com a participação conjunta das nações.

\footnotetext{
${ }^{19}$ SCAFF, Fernando Facury; TUPIASSU, Lise Vieira da Costa. Tributação e políticas públicas: o ICMS ecológico. In: TÔRRES, Heleno Taveira (Org.). Direito tributário ambiental. São Paulo: Malheiros, 2005. p. 731 .
} 


\subsection{Evolução da discussão internacional sobre a matéria ambiental}

Até a década de 70 do século XX, a questão ambiental ocupou plano secundário no cenário mundial. Todavia, a histórica Conferência das Nações Unidas pela Organização das Nações Unidas - ONU, ocorrida em 1972, em Estocolmo, representou uma tomada de consciência da Comunidade das Nações para esse problema universal.

Com efeito, em 1987, o Relatório Brundtland, também designado de Relatório Nosso Futuro Comum, da Comissão Mundial de Meio Ambiente e Desenvolvimento, difundiu a ideia de desenvolvimento sustentável, sendo proposta uma aproximação entre a noção de preservação dos recursos naturais e a de avanços econômicos.

Em 1992, o Rio de Janeiro sediou a conferência das Nações Unidas conhecida como ECO 92. Em tal conferência, o debate acerca do desenvolvimento sustentável avançou, tendo sido traçadas estratégias regionais e globais para que este fosse atingido.

Cumpre ressaltar que relevantes documentos foram elaborados em tal oportunidade, a exemplo da Agenda 21 e da Convenção sobre Mudanças Climáticas, no bojo dos quais restou evidenciado que a redução da emissão de gases de efeito estufa era medida necessária e urgente.

Em 1997, na cidade de Quioto, ocorreu a Conferência dos Estados partes, na qual foram firmados critérios e metas de redução de efeito estufa, bem como prevista a utilização de mecanismos de mercado com o objetivo de promover tal redução. O resultado desse encontro tornou-se amplamente difundido sob a denominação de "Protocolo de Quioto".

Acordou-se que os países ricos iriam reduzir cerca de 5\% do total de emissões lançadas ao meio ambiente em 1990, ao passo que os países em desenvolvimento estariam dispensados de cumprir essas metas.

O Protocolo de Quioto, ao conceber a utilização de mecanismos de mercado como meio de diminuir a emissão de gases que provocam o efeito estufa, trouxe relevante contribuição à questão ambiental.

Destaque-se que, durante a Conferência das Partes (COP - 11), em Montreal, no ano de 2005, o Protocolo de Quioto entrou em vigor com a adesão da Rússia, com a qual se 
alcançou a soma das nações responsáveis por $55 \%$ do total das emissões mundiais de gases de efeito estufa.

Dois anos depois, em 2007, um alerta foi trazido à tona pelos cientistas do Painel Intergovernamental sobre Mudanças Climáticas (IPCC). Foi revelado que a temperatura média do planeta havia subido em $0,76 .^{\circ} \mathrm{C}$ no século $\mathrm{XX}$ e que a manutenção dos processos em curso geraria consequências climáticas graves.

A despeito da constatação em tela, a Conferência das Partes 15 (COP - 15), ocorrida no ano de 2009, em Copenhague, não logrou fixar um novo acordo internacional para suceder o Protocolo de Quioto, cuja validade acabaria em 2012.

Entretanto, no encontro seguinte, COP - 16, sediado na cidade do México, em 2010, chegou-se a um consenso quanto à criação de um Fundo Verde, com o qual as nações desenvolvidas deveriam colaborar financeiramente para que as nações em desenvolvimento pudessem investir no combate às mudanças climáticas.

No ano seguinte, ocorreu, em Durban, África do Sul, a COP - 17, cujos destaques foram a prorrogação da vigência do Protocolo de Quioto para 2017 e a adoção da Plataforma Durban, novo pacto em que até os países menos desenvolvidos assumiram a obrigação de cumprir metas para a redução das emissões de carbono a partir de 2015.

Transcorridos 20 anos da Eco 92, o Rio de Janeiro voltou a sediar Conferência de relevo, trazendo para sua Capital a Rio+20. A tônica desse encontro foi a busca por uma “economia verde", responsável por desacelerar a destruição ambiental, combater a pobreza e reduzir as desigualdades. Contudo, não foi possível a fixação de metas nem a indicação da origem dos recursos necessários para viabilizar a referida "economia verde". Nesta perspectiva, o preenchimento dessas e de outras lacunas restou postergado para os próximos encontros.

Por seu turno, a conferência de Doha, no Quatar, ocorrida no mês de dezembro do ano de 2012 (COP 18), frustrou as expectativas de finalizar negociações pendentes, tendo apenas avançado em relação à revalidação do Protocolo de Quioto até 2020, único acordo ainda ativo pelo qual parte dos países ricos se compromete a reduzir seus gases poluentes.

Saliente-se que a ONU promoveu diversas outras conferências para tratar da questão ambiental, tais como as ocorridas em Buenos Aires (1998), Haia (2000), Marrakesh (2001), Johannesburgo (2002) - chamada "Rio+10" -, Moscou (2003), Paris (2006). 
Essas sucessivas reuniões demonstram a relevância que a questão ambiental tem para as nações. Entretanto, ainda existe um longo caminho a ser trilhado para a obtenção de um consenso acerca das medidas que deverão ser adotadas pelos Estados para solucionar essa matéria e de onde sairão os recursos necessários à sua implementação.

O que se verifica é que países desenvolvidos resistem em assumir a responsabilidade pelas perdas decorrentes de acidentes ambientais e em disponibilizar recursos para apoiar a redução das emissões efetuadas por países em desenvolvimento, revelando, assim, que a cooperação internacional para o desenvolvimento sustentável está caminhando a passos lentos.

\subsection{Princípios Ambientais}

\subsubsection{Princípio do poluidor-pagador}

Amplamente difundido no âmbito do direito ambiental internacional e nacional, o princípio do poluidor-pagador propõe a internalização dos prejuízos ambientais causados pelo poluidor, evitando-se, assim, que a sociedade e o Poder Público sejam onerados com este "custo" 20 e que o poluidor experimente um enriquecimento sem causa.

Isto porque, como é cediço, além do produto a ser comercializado, o processo produtivo traz como resultado "externalidades", que podem ser classificadas como positivas ou negativas, a depender do impacto sofrido pela sociedade.

Nesta linha de raciocínio, a poluição oriunda dos processos industriais é tida, por óbvio, como uma externalidade negativa. Por sua vez, a aquisição e a respectiva adoção de equipamento que reduz as emissões de poluentes constituem uma externalidade positiva ${ }^{21}$.

\footnotetext{
${ }^{20}$ Acerca dos custos a serem considerados, registra a Professora Ana Maria de Oliveira Nusdeo que: "O poluidor-pagador, embora genericamente associado à responsabilização civil e à reparação de danos já consumados, tem seu significado relacionado também à alocação de custos de prevenção de dano. Nesse sentido, é voltado à afecção dos custos das medidas de prevenção e controle da poluição ao empreendedor e ao estímulo da utilização racional dos recursos ambientais escassos. Está na base do princípio do poluidorpagador a ideia de que o preço dos bens e serviços que causam poluição deve refletir o custo das medidas mitigadoras. Aí, então, aqueles que usufruem um produto ou serviço devem arcar, por meio da internalização ao preço, com as medidas mitigadoras do seu impacto ambiental" (NUSDEO, Ana Maria de Oliveira. Pagamento por serviços ambientais: sustentabilidade e disciplina jurídica. São Paulo: Atlas, 2012. p. 138).

${ }^{21}$ Acerca das externalidades como falha de mercado, item 1.6.3.
} 
Com efeito, o princípio em foco, além de determinar que aquele que explora a atividade poluidora realize investimentos para a preservação do meio ambiente, impõe que seja onerada a degradação por ele efetivada. Ademais, é possível identificar autorização para se premiar aqueles agentes que atuam de forma ambientalmente responsável, concedendo-lhes tratamento diferenciado.

A esse respeito pondera Simone Martins Sebastião ${ }^{22}$ : "na mesma medida que o princípio do poluidor-pagador prega a internalização das externalidades ambientais negativas, dele decorre, como corolário lógico, que as externalidades positivas nessa seara devem ser estimuladas e recompensadas".

Embora não seja a clássica interpretação conferida ao princípio do poluidorpagador, o presente trabalho adota uma acepção ampla deste cânone, segundo a qual é possível premiar os indivíduos que realizam atividades das quais resultam externalidades positivas.

Advirta-se, que o conteúdo amplamente divulgado do princípio em voga, que propõe a internalização dos custos ambientais para sua integração no preço dos produtos e serviços, não pode ser confundido com uma "autorização para poluir". O objetivo é onerar o agente econômico com os custos da prevenção e monitoramento da poluição, para que seja afastada a ideia de que os bens ambientais são infinitos e passíveis de ser explorados sem qualquer ônus para o agente poluidor.

Deveras, o princípio do poluidor-pagador não corresponde à concessão de uma carta branca para a degradação do meio ambiente em face de um pagamento efetuado.

\subsubsection{Princípio da prevenção e da precaução}

Há, também, o princípio ambiental da prevenção e da precaução, fruto da ideia de que, a par da necessidade de se buscar mecanismos para reverter degradações ambientais e inibir atividades poluentes, mister se faz adotar medidas preventivas.

Com efeito, as políticas públicas, ainda que estabeleçam meios de reparação às lesões causadas em desfavor do meio ambiente, buscam dirimir as possibilidades de ocorrência do impacto ambiental.

\footnotetext{
${ }^{22}$ SEBASTIÃO, Simone Martins. Tributo ambiental. 1. ed. 6. ${ }^{a}$ reimpressão. Curitiba: Juruá, 2011. p. 258.
} 
Esta acepção ganha força com base na constatação de que as lesões ao meio ambiente são de difícil e, em alguns casos, de impossível reversão. Assim, uma vez gerado um dano à natureza, sua reintegração, além de ser excessivamente dispendiosa, é muitas vezes irreversível. Tal cenário torna imperiosa a necessidade de se adotar mecanismos para a aplicação do princípio em questão.

Nessa esteira, o princípio da prevenção e da precaução tem o importante papel de evitar a ocorrência do dano ambiental, mediante a cognição antecipatória do potencial lesivo de atos e medidas direcionados ao meio ambiente.

Pacificado o caráter prévio do princípio da precaução e da prevenção no tocante à lesão ambiental, cumpre consignar que a doutrina nem sempre os trata de forma abrangente, tal como proposto no presente estudo.

Com efeito, ressalte-se que na mesma linha ora perfilhada posiciona-se Vasco Pereira da Silva ${ }^{23}$, para quem deve ser adotada uma noção ampla de prevenção, em detrimento da sua separação do princípio da precaução. Para o aludido autor, um único conceito conglobante revela-se adequado para resolver os problemas decorrentes da matéria em foco.

Entretanto, há quem prefira delimitar a dimensão dos aludidos princípios procedendo à autonomização do princípio da precaução em relação ao princípio da prevenção. É a posição de José Rubens Morato Leite e de Patryck de Araújo Ayala ${ }^{24}$, segundo a qual “[...] o princípio da prevenção se dá em relação ao perigo concreto, enquanto, em se tratando do princípio da precaução, a prevenção é dirigida ao perigo abstrato".

Em geral, entende-se que, enquanto a prevenção exige que os riscos atestados sejam afastados, o principio da precaução demandaria que as medidas preventivas fossem adotadas antes mesmo de haver a comprovação científica acerca do nexo causal.

Ultrapassada a questão conceitual do principio em tela, importa pontuar que, na linha do paradigma jurídico ambiental da Constituição de 1988, o princípio da prevenção e da precaução foi consagrado na declaração de princípios na Conferência das Nações

\footnotetext{
${ }^{23}$ SILVA, Vasco Pereira da. "Mais vale prevenir do que remediar": prevenção e precaução no direito do ambiente. In: PES, João Hélio Ferreira; OLIVEIRA, Rafael Santos de (Coord.). Direito ambiental contemporâneo: prevenção e precaução. Curitiba: Juruá, 2009. p. 14.

${ }^{24}$ LEITE, José Rubens Morato; AYALA, Patryck de Araújo. Direito ambiental na sociedade de risco. 2. ed. rev., atual. e ampl. Rio de Janeiro: Forense Universitária, 2004. p. 71.
} 
Unidas sobre Meio Ambiente e Desenvolvimento, sediada no Rio de Janeiro em 1992, nos moldes a seguir dispostos:

Princípio 15: Com o fim de proteger o meio ambiente, o princípio da precaução deverá ser amplamente observado pelos Estados, de acordo com suas capacidades. Quando houver ameaça de danos graves ou irreversíveis, a ausência de certeza científica absoluta não será utilizada como razão para o adiamento de medidas economicamente viáveis para prevenir a degradação ambiental.

De tal sorte, o princípio da prevenção e da precaução assenta as bases para a prevalência da atuação preventiva em face da voracidade do mercado por resultados econômicos em curto prazo, pois é por intermédio de medidas acautelatórias que se pode alcançar um meio ambiente sadio, conforme determina a Lei Maior em seu art. 225.

Este princípio é concretizado por meio da adoção de práticas que vão além da normatização de condutas proibidas, podendo ser efetivado, na seara tributária, mediante medidas fiscais que irão inibir as condutas que impactam o meio ambiente, consoante pontifica Pedro M. Herrera Molina ${ }^{25}$ :

\begin{abstract}
Algunas medidas fiscales de protección ambiental pueden resultar idóneas para poner em práctica el principio de acción preventiva, pues ante la mera sospecha de riesgo no siempre será posible ni conveniente establecer rígidas prohibiciones administrativas. Em tales casos el principio de ponderación de bienes jurídicos unido al de cautela aconseja el establecimiento de medidas tributarias desincentivadoras.
\end{abstract}

Note-se que o ordenamento jurídico nacional concretiza o princípio em foco ao exigir a avaliação de impactos ambientais, que condiciona o licenciamento prévio de determinadas atividades ou empreendimentos a um Estudo de Impacto Ambiental elaborado com o emprego da melhor tecnologia disponível para avaliar os potenciais riscos representados pelo empreendimento ou atividade em análise ${ }^{26}$.

\footnotetext{
${ }^{25}$ HERRERA MOLINA, P. Derecho tributário ambiental. Madrid: Marcial Pons, 2000. p. 37.

26 LEITE, José Rubens Morato; MELO, Melissa Ely. As funções preventivas e precaucionais da responsabilidade civil por danos ambientais. In: PES, João Hélio Ferreira; OLIVEIRA, Rafael Santos de (Coord.). Direito ambiental contemporâneo: prevenção e precaução. Curitiba: Juruá, 2009. p. 66.
} 


\subsubsection{Princípio do protetor-recebedor}

Por meio do princípio do protetor-recebedor, aqueles que protegem um bem natural em benefício da comunidade recebem compensação financeira como incentivo à prestação de serviço de proteção ambiental e às condutas ambientalmente corretas.

Não obstante já existisse na prática, sendo aplicado pelo Poder Público por meio de medidas compensatórias pontuais para aqueles que agem em benefício do meio ambiente, tal princípio foi positivado, em âmbito nacional, com a edição da Lei n. ${ }^{\circ}$ 12.305/2010, que instituiu a Política Nacional dos Resíduos Sólidos.

Segundo Frederico Augusto Di Trindade $\mathrm{Amado}^{27}$, o princípio do protetorrecebedor constitui "uma espécie de compensação pela prestação dos serviços ambientais em favor daqueles que atuam em defesa do meio ambiente, como verdadeira maneira de se promover a justiça ambiental".

O primado sob análise remete a uma ideia de contrapartida àqueles que contribuem para a manutenção dos ecossistemas que oferecem os serviços ambientais. É uma estratégia de incentivo (incentivo positivo) àqueles que preservam, por meio do qual recebem uma contrapartida pelo custo de oportunidade do uso do recurso natural (como o solo, a flora e os recursos hídricos) ${ }^{28}$.

Ana Maria de Oliveira Nusdeo ${ }^{29}$, em obra dedicada ao tema do pagamento por serviços ambientais, traz a seguinte definição acerca do primado em comento:

O princípio do protetor-recebedor, que começa a ser discutido no contexto dos debates sobre o pagamento por serviços ambientais, propõe $\mathrm{o}$ pagamento àqueles agentes cuja ação promove o incremento dos serviços ambientais prestados pela natureza. Conforme já referido, Rubens Born e Sérgio Talocchi apresentam o princípio com base na ideia de "ajuda" à natureza. Isso porque as práticas humanas podem degradar ou destruir as condições de prestação do serviço ou podem, ao contrário, reforçá-las e protegê-las, merecendo então uma compensação.

Os autores não se referem especificamente à figura das externalidades positivas, mas elas poderiam ser identificadas na atuação do protetorrecebedor. Aquele cujas práticas produzem externalidades positivas faz jus ao recebimento de uma remuneração como forma de internalizá-las.

\footnotetext{
${ }^{27}$ AMADO, Frederico Augusto Di Trindade. Direito ambiental esquematizado. 3. ed. Rio de Janeiro: Forense; São Paulo: Método, 2012. p. 72-73.

28 GUIMARÃES, Renan Eschiletti Machado. Incentivos fiscais no direito ambiental e a efetivação do princípio do protetor-recebedor na política nacional de resíduos sólidos (Lei $n .{ }^{\circ}$ 12.305/2010). Porto Alegre: Buqui, 2012. p. 40.

${ }^{29}$ NUSDEO, Ana Maria de Oliveira. Op. cit., p. 69.
} 
Trata-se, pois, de um princípio que reforça a necessidade e a tendência que vem se consolidando em todo o mundo de um Direito Ambiental baseado nos conceitos e ditames da prevenção, beneficiando o protetor que age em conformidade com os preceitos ecológicos.

O objetivo dessa prevenção é incentivar práticas, como, por exemplo, a proteção à biodiversidade, a proteção de bacias hidrográficas, o pagamento pela beleza cênica, o sequestro e o armazenamento de carbono, o surgimento de áreas verdes privadas, as Reservas Particulares de Patrimônio Natural.

Revela-se, pois, um princípio inovador, uma vez que diverso do direito repressivo e sancionatório a que a sociedade sempre esteve acostumada, considerando as regras de caráter ambiental costumeiramente como sanções negativas, de natureza punitiva.

A crítica que o primado em testilha vem sofrendo refere-se ao fato de que, diante dos riscos ambientais existentes, alguns governos e parte da sociedade vêm exigindo que as pessoas tenham atitudes sustentáveis e voltadas à preservação do meio ambiente, independentemente de benefícios.

Ocorre que, consoante já abordado no item 1.1, os ditames da economia atual (calcada no capitalismo, voltada ao lucro imediato e dependente de competitividade) e as crises financeiras fazem com que os atores sociais não priorizem a questão ambiental, o que acaba por demandar mecanismos de estímulo para aqueles que protegem o meio ambiente. Ora, em contextos de escassez de recursos financeiros, a disposição a receber é mais alta do que a disposição a pagar.

Neste compasso, uma vez que a clássica acepção do princípio do poluidor-pagador relaciona-se com a obrigatoriedade de o poluidor arcar com os custos da degradação ambiental por ele desencadeada e a do princípio do protetor-recebedor com uma forma de proporcionar uma equidade econômica, premiando aquele que preserva, conclui-se que ambos os princípios trazem benefícios reais ao meio ambiente e a toda a sociedade.

Elizangela Treméa ${ }^{30}$ traz a reflexão de que, diante de acentuados riscos globais, fazse necessária a implementação de políticas públicas que visem à economia ecológica e à

\footnotetext{
${ }^{30}$ FELL, Elizangela Treméa; TREMÉA, Estela Maria. O princípio do protetor-recebedor e o proambiente: Limites e possibilidade da compensação financeira. Ambito Jurídico, Rio Grande, v. 11, n. 51, mar. 2008. Disponível $<$ http://www.ambitojuridico.com.br/site/index.php?n_link=revista_artigos_leitura\&artigo_id=2482>. Acesso em: set. 2012.
} 
democratização ambiental, buscando a interdependência da economia e da ecologia como critério viabilizador de justiça ambiental. De tal sorte, os atores sociais que tenham sensibilidade ecológica e contribuam para a preservação/conservação do meio ambiente, devem receber alguma forma de incentivo financeiro.

A efetivação desse princípio ainda carece, no país, de políticas públicas mais numerosas e efetivas, com a criação de mais leis disciplinando de que forma tais benefícios/retribuições serão disponibilizados. Entretanto, esse princípio já possui alguns exemplos práticos.

Com efeito, mediante a edição da Lei n. ${ }^{0}$ 12.512/2011, que institui o Programa de Apoio à Preservação Ambiental, a União fica autorizada a transferir recursos financeiros e a disponibilizar serviços de assistência técnica a famílias em situação de extrema pobreza que desenvolvam atividades de conservação de recursos naturais no meio rural.

Cumpre mencionar, ainda, iniciativa do Estado de Minas Gerais, que, por meio da Lei n. ${ }^{\circ}$ 17.727/2008, instituiu a concessão de incentivo financeiro a proprietários e posseiros rurais, sob a denominação de Bolsa Verde, para identificação, recuperação, preservação e conservação de áreas necessárias à proteção das formações ciliares e à recarga de aquíferos e áreas necessárias à proteção da biodiversidade e ecossistemas especialmente sensíveis.

Referido benefício é concedido anualmente, para fins do que especifica a Política Estadual de Recursos Hídricos, em forma de auxílio pecuniário e nas condições previstas em regulamento.

Portanto, assiste razão a Renan Eschiletti Machado ${ }^{31}$ quando este defende que "os instrumentos tributários têm sido a escolha mais comum para a efetivação deste princípio ambiental, sendo os incentivos fiscais os mais destacados deles" e conclui ${ }^{32}$ :

Destarte, o incentivo fiscal revela-se como importante, senão o mais eficaz, instrumento de efetivação do princípio do protetor-recebedor na Política Nacional de Resíduos Sólidos, já estimulando e tendo o potencial de estimular ainda mais a sociedade e o poder público a compartilhar responsabilidades e a promover, verdadeiramente, o desenvolvimento sustentável.

\footnotetext{
${ }^{31}$ GUIMARÃES, Renan Eschiletti Machado. Op. cit., p. 51.

${ }^{32}$ Id. Ibid., p. 52.
} 
Fincadas as principais características acerca dos princípios do poluidor-pagador, da prevenção e da precaução e do protetor-recebedor, cumpre investigar como a questão ambiental é tratada pela Lei Maior, identificando-se, assim, em que medida os aludidos primados teriam meios de ser aplicados.

\subsection{Tutela constitucional do meio ambiente}

Conforme já mencionado, em 1988, ano em que a denominada Constituição Cidadã foi promulgada, o meio ambiente e os princípios norteadores do direito ambiental já eram alvo de reflexão em Conferências Internacionais.

Com efeito, o tema foi enfrentado pelo constituinte original, que contemplou vários dispositivos $^{33}$ expressos a seu respeito, podendo ser correlacionado a outros tantos princípios e regras presentes no texto da Lei Maior.

De fato, a Constituição Federal de 1988, na esteira das Constituições elaboradas após a Segunda Guerra Mundial, albergou vastos catálogos de direitos e garantias fundamentais e direitos sociais, tendo ainda contemplado diversas normas, ao longo do seu texto, que se relacionam, direta ou indiretamente, com a preservação ambiental.

Ao versar sobre os direitos e garantias fundamentais, a Lei Maior assegurou, logo no caput do art. 5. ${ }^{\circ}$, o direito à vida, restando evidente, pois, a necessidade de manutenção de um meio ambiente adequado à sobrevivência humana.

Por sua vez, no capítulo dedicado aos direitos sociais, tutelou o direito à saúde, à alimentação e à moradia, os quais também se encontram indissociavelmente atrelados a um meio ambiente equilibrado.

A dignidade da pessoa humana, avistável no art. $1^{\circ}$ da Constituição Federal e que constitui fundamento da República Federativa do Brasil, tida como mandamento central do Sistema Constitucional pátrio, também se vincula à existência da vida humana em um meio ambiente sadio.

\footnotetext{
${ }^{33}$ Constituição Federal de 1998: arts. 20, II, IX e X; 22, IV e XII; 23, III, IV, VI e VII; 24, VI, VII e VIII; 129, III; 170, III e IV; 174, § 3..$^{\circ} ; 182 ; 183 ; 184 ; 186$, II; 184; 196 a 200; 205, 215; 216; 218; $219 ; 220$ a 24 ; e 226 a 230 .
} 
Por seu turno, constitui objetivo fundamental da República, plasmado do art. $3 .^{\circ}$ da Carta Política, o desenvolvimento nacional. De fato, busca-se o avanço tecnológico, econômico e social. Contudo, todo esse desenvolvimento não deve ser efetivado a qualquer custo, senão de forma sustentável, com o uso racional dos recursos disponíveis.

Assim é que uma indústria que aufere maior lucro por força de tecnologia que melhora a eficiência energética do seu processo industrial está concretizando o mencionado princípio constitucional de forma mais contundente do que na hipótese de a sua lucratividade ser experimentada apenas em função do aumento da demanda, sem o mencionado avanço tecnológico que trouxe mudanças na sua base produtiva e efeitos positivos para a sociedade em geral.

De fato, a análise do desenvolvimento nacional fulcrada apenas na elevação do Produto Interno Bruto (PIB) não irá revelar se o país cresce de forma estruturada e com perspectivas de manutenção de crescimento a longo prazo, e tampouco retrata se esse crescimento resulta numa melhora na vida das pessoas, tanto no seu aspecto cultural, quanto nos de saúde e de satisfação de necessidades mínimas de sobrevivência.

Ressalte-se que a promoção do bem de todos também consubstancia objetivo a ser alcançado (art. 3. ${ }^{\circ}$ da $\mathrm{CF} / 1988$ ), não se podendo imaginar a promoção do bem das pessoas sem um meio ambiente com condições de sobrevivência e acesso aos bens ambientais.

Note-se que a matéria em comento figura, ainda, no rol dos princípios da ordem econômica elencados pelo art. 170 da Carta Magna, orientadores da atividade econômica pátria, os quais imprimem ao Estado uma feição intervencionista, consoante se verá, nos tópicos seguintes, de forma mais detalhada.

Além de expressa diretriz econômica que determina a defesa do meio ambiente mediante tratamento diferenciado de bens, serviços e modo de produção com base em critérios de sustentabilidade, a questão ambiental também foi explicitada de forma robusta na Constituição em capítulo específico.De fato, o art. 225 contempla inúmeras regras e princípios que buscam efetivar a proteção do meio ambiente. Registre-se a dicção do caput do aludido preceito:

Todos têm direito ao meio ambiente ecologicamente equilibrado, bem de uso comum do povo e essencial à sadia qualidade de vida, impondo-se ao Poder Público e à coletividade o dever de defendê-lo e preservá-lo para as presentes e futuras gerações. 
Da análise do conteúdo do comando legal acima reproduzido, é possível concluir que, constitucionalmente, o meio ambiente: i) é um direito de todos, de forma que brasileiros e estrangeiros residentes são dele titulares; ii) constitui um bem ambiental de uso comum, passível de ser fruído pelas pessoas e não destruído por alguém ou pela comunidade; iii) impõe dever de defesa e preservação tanto ao Estado quanto à sociedade; e iv) sua tutela se refere a direito difuso, alcançando-se gerações futuras.

Para fins deste estudo, ganha relevo a determinação contida no bojo do artigo em referência de que cabe ao Estado e à sociedade promover a prevenção, controle, preservação, estímulo e reparo de danos causados ao meio ambiente, a fim de que este se mantenha para gerações futuras. Tal imposição denota que ambos deverão abrir mão de parcela de seus direitos em prol da questão ambiental.

Eros Roberto Grau ${ }^{34}$, ao analisar a tutela constitucional do meio ambiente, defende que a postura adotada pela Lei Maior se revela bastante vigorosa, afastando-se de vez a ideia de que a proteção da natureza significa o retorno à barbárie. Segundo o mencionado autor, a defesa do meio ambiente, além de informar os princípios da garantia do desenvolvimento e do pleno emprego e figurar como instrumento indispensável para assegurar a existência digna, também nutre os ditames da justiça social, porquanto a todos é garantido o direito ao meio ambiente ecologicamente equilibrado.

Cumpre pontuar que, como disposição geral da ordem social, o constituinte estipulou, por meio do art. 193, que esta teria como base "o primado do trabalho, e como objetivo o bem-estar e a justiça sociais".

Nesse sentido, a defesa do meio ambiente também inserida no Título VIII "Da Ordem Social", deve harmonizar-se com tal comando, estando em consonância tanto com as atividades laborativas desenvolvidas no país, quanto com a promoção da qualidade de vida e justiça social.

De tal sorte, a proteção do meio ambiente visará a promover: i) o adequado ambiente de trabalho, ii) o desenvolvimento das atividades laborativas em conformidade com as preocupações ambientais, iii) o bem-estar da comunidade e iv) a busca pela igualdade social.

\footnotetext{
${ }^{34}$ GRAU, Eros Roberto. A ordem econômica na Constituição de 1988. 11. ed. São Paulo: Malheiros, 2006. p. 219.
} 
Observa-se, assim, que o dever de preservação do meio ambiente, imerso de modo específico no cenário da ordem social, não pode ser interpretado de modo apartado dos demais aspectos sociais plasmados em tal sede.

O aludido imbricamento deixa estampada a opção do constituinte de 1988 por um desenvolvimento sustentável, que se encontra, como já ressaltado, calcado no tripé social, econômico e ecológico.

\subsection{Ordem econômica e meio ambiente}

\subsubsection{Formas de atuação estatal na ordem econômica}

Alerta José Afonso da Silva ${ }^{35}$ que, ao se utilizar a expressão ordem econômica, há de se distinguir a ordem econômica ontológica, que corresponde à forma empírica de determinada economia, abarcando a realidade das relações entre seus diversos agentes (comumente denominado players) e fatores, da deontológica, referente ao conjunto de normas que regula a atividade econômica e seus partícipes, o sistema normativoeconômico.

Vale ressaltar que a ordem econômica adquiriu dimensão jurídica por intermédio da sua regulação sistemática em sede constitucional, a qual teve início com a Constituição Mexicana de 1917. No Brasil, a Constituição de 1934 foi a primeira a disciplinar a ordem econômica.

No mundo ocidental, em regra, a ordem econômica está calcada na iniciativa privada, detentora dos meios de produção, predominando o capitalismo. O Estado busca conter a vida econômica e social estabelecendo limites ao liberalismo desenfreado.

Com efeito, são dos condicionamentos impostos à atividade econômica que se originam os direitos econômicos, os quais são o conteúdo da constituição econômica ${ }^{36}$.

\footnotetext{
${ }^{35}$ SILVA, José Afonso da. Curso de direito constitucional positivo. 28. ed. São Paulo: Malheiros, 2006. p. 793.

${ }^{36}$ Constituição econômica é conceito bem debatido. Vital Moreira: “A CE é, pois, o conjunto de preceitos e instituições jurídicas que, garantindo os elementos definidores de um determinado sistema econômico, instituem uma determinada forma de organização e funcionamento da economia e constituem, por isso mesmo, uma determinada ordem econômica".
} 
No Brasil, a ordem econômica encontra-se calcada na i) valorização do trabalho humano e ii) na iniciativa privada (art. 170 da CF/1988). Tais valores orientam a intervenção do Estado na Economia e têm como escopo salvaguardar uma existência digna e conforme aos ditames da justiça social, observados os princípios da:

a) soberania nacional;

b) propriedade privada;

c) função social da propriedade;

d) livre concorrência;

e) defesa do consumidor;

f) defesa do meio ambiente, inclusive mediante tratamento diferenciado conforme o impacto ambiental de produtos e serviços e de seus processos de produção;

g) redução das desigualdades sociais;

h) busca do pleno emprego;

i) tratamento favorecido para as empresas de pequeno porte.

Nesta perspectiva, a Constituição estipula como objetivo da ordem econômica assegurar a todos existência digna, consoante os ditames da justiça social, sendo a compatibilização entre a livre-iniciativa e a valorização do trabalho humano a sua base fundante.

Postos os objetivos e o alicerce fulcral da ordem econômica, a Carta Política cuidou de elencar os princípios que irão norteá-la, a exemplo da soberania nacional, propriedade privada, livre concorrência, defesa do meio ambiente, busca pelo pleno emprego, dentre outros.

Resta claro, portanto, que no país as atividades econômicas (executadas pelos particulares ou pelo Estado) não podem ser desenvolvidas livremente, mas estão adstritas aos princípios constitucionais da ordem econômica, aos seus objetivos e alicerces fundantes.

Ademais, dentro da conformação acima delineada, o ente estatal, mediante normas oriundas do Direito Econômico, irá instituir variáveis compulsórias ou facultativas que irão influenciar a tomada de decisão do agente econômico no exercício de sua liberdade de 
empreender ${ }^{37}$. As normas são estipuladas para alinhar a dinâmica econômica aos objetivos constitucionais.

Nesse sentido, Fernando Herren Aguilar ${ }^{38}$, após defender que o Direito Econômico é "o direito das políticas públicas na economia", constituindo um conjunto de normas e institutos jurídicos que permitem que o Estado exerça influência, oriente, direcione, estimule, proíba ou reprima comportamento dos agentes econômicos num certo país ou conjunto de países, traz diversos exemplos da sua concretização no Brasil. Frise-se a dicção desse autor acerca da utilidade concreta do Direito Econômico, no Brasil:

Ele já serviu para socorrer produtores ameaçados de colapso financeiro, para congelar preços em períodos de inflação descontrolada, para aumentar exportações em períodos de crise cambial, para combater cartéis empresariais. Ele já serviu para aumentar o nível de emprego, estimular o desenvolvimento regional, fixar a taxa de juros, direcionar a economia para atingir determinados objetivos, reprimir determinadas práticas que julgasse nocivas à economia. Já houve um tempo em que a evolução dos preços era combatida com tabelamento pelo governo. Hoje se combate a inflação com abertura alfandegária. A fixação das cotações da moeda nacional já foi feita por norma do Banco Central. Hoje o câmbio é flutuante, de acordo com a oferta e a procura da moeda.

Feitas tais considerações, cumpre examinar as formas de atuação estatal na economia.

De início, cumpre distinguir atuação estatal de intervenção estatal. Com efeito, esclarece Eros Roberto $\mathrm{Grau}^{39}$ que as referidas expressões são apenas relativamente intercambiáveis. Isto porque, quando o Estado está prestando um serviço público ou regulando a prestação de um serviço público, não pratica uma intervenção, mas uma atuação na sua própria área de titularidade (esfera pública).

Nesta perspectiva, preleciona o citado jurista que, enquanto a atuação estatal designa significado mais abrangente de atuação do Estado, porquanto abarcará tanto a área de sua titularidade quanto a de titularidade do setor privado, a intervenção corresponderá à atuação na área de titularidade do setor privado.

\footnotetext{
${ }^{37}$ AGUILLAR, Fernando Herren. Direito econômico: do direito nacional ao direito supranacional. 2. ed. São Paulo: Atlas, 2009. p. 2-3.

${ }^{38}$ Id., loc. cit.

${ }^{39}$ GRAU, Eros Roberto. A ordem econômica na Constituição de 1988, cit., p. 130-131.
} 
De tal modo, a intervenção conota atuação estatal no campo da atividade econômica em sentido estrito e a atuação estatal evidencia ação do Estado no campo da atividade em sentido amplo.

Considerando que a intervenção é o termo adequado para tratar da atuação estatal na seara da atividade econômica em sentido estrito, ou seja, para referir a intervenção no "domínio econômico", passa-se ao exame mais detido de tal figura, uma vez que os incentivos fiscais são verificados na seara da atividade econômica em sentido estrito (esfera privada).

Cabe, então, apresentar a consagrada classificação das modalidades de intervenção formulada por Eros Roberto Grau, a saber: i) intervenção por absorção ou participação, ii) intervenção por direção e iii) intervenção por indução.

Deveras, na primeira modalidade, o ente estatal intervém no domínio econômico e figura como sujeito econômico. A intervenção no domínio econômico por absorção ocorre quando o Estado assume a totalidade do controle dos meios de produção e/ou troca em determinado setor da atividade econômica em sentido estrito, atuando em regime de monopólio. Por seu turno, esta se dá por participação quando tal ente controla parte dos meios de produção e/ou troca em determinado setor da atividade econômica, atuando em regime de competição com empresas privadas ${ }^{40}$.

Seguindo a classificação em tela, verifica-se que, nas duas outras modalidades, o Estado não intervirá no domínio econômico, mas sobre o domínio econômico. A atuação é sobre o campo da atividade econômica em sentido estrito, por meio de regulação dessa atividade, que pode ocorrer por direção ou indução.

Encontrar-se-á na esfera da intervenção sobre o domínio econômico por direção a intervenção executada por meio de "pressão sobre a economia, com o estabelecimento de mecanismos e normas de comportamento compulsório para os sujeitos da atividade econômica em sentido estrito". Há, pois, comandos cogentes, impositivos de condutas, sendo o clássico exemplo de tal modalidade o congelamento de preços estipulado pelo Estado $^{41}$.

Por sua vez, a indução está presente quando o Estado se vale de instrumentos de intervenção alinhados às leis que regem o funcionamento dos mercados. Utiliza-se assim

\footnotetext{
${ }^{40}$ GRAU, Eros Roberto. A ordem econômica na Constituição de 1988, cit., p. 175.

${ }^{41}$ Id. ibid., p. 175-176.
} 
de preceitos que, apesar de prescritivos, não detêm a mesma cogência das normas de direção, visto que são normas dispositivas que trazem um convite ou estímulo para que o destinatário participe da atividade de interesse do Estado $^{42}$.

Nessa perspectiva, se há a adesão à norma, caberá o cumprimento das prescrições legais ${ }^{43}$.

Verifica-se que, ao optar pela intervenção por indução, o Estado, diante do contexto do mercado, cria norma que irá influenciar na formação de vontade do agente econômico, pois caberá a este adotar o comportamento preconizado pela norma ou não, sem que tal alternativa constitua ilícito.

Luís Eduardo Schoueri ${ }^{44}$ esclarece tal ponto ao aduzir que a norma de intervenção por indução também alberga o funtor "obrigatório", estando a sua peculiaridade atrelada à possibilidade de seu destinatário adotar, ou não, um comportamento. De acordo com sua escolha, o ordenamento lhe imputará uma consequência.

Cumpre pontuar que a norma de indução não só poderá abrandar determinada situação com objetivo de fomentar a prática de determinado ato, como também poderá agravar situações com o escopo de inibir comportamentos. Assim, por exemplo, haverá indução negativa quando for editada norma elevando a tributação na importação de certo bem, desestimulando-se, assim, a entrada de tal bem no país.

Impõe ressaltar que, na prática, a distinção entre normas de indução e de direção nem sempre é de fácil aferição, permanecendo, todavia, o critério jurídico da identificação do grau de liberdade do administrado ${ }^{45}$.

No caso dos incentivos fiscais, objeto de estudo do Capítulo 3, a distinção em destaque revela-se apropriada, porquanto tais incentivos ocorrem na seara tributária, que pressupõe a liberdade do particular para a realização ou não do fato gerador. Nesse sentido, resta completamente afastada a sua classificação como norma de direção.

Ao tratar sobre aspectos da intervenção por intervenção e por indução, com base em considerações oriundas do direito das finanças, Luís Eduardo Schoueri ${ }^{46}$ aduz que as normas de direção são mais bem aplicadas nos casos em que se demanda de todos um

${ }^{42}$ GRAU, Eros Roberto. A ordem econômica na Constituição de 1988, cit., p. 175-176.

${ }^{43}$ Id. ibid., p. 176.

${ }^{44}$ SCHOUERI, Luís Eduardo. Normas tributárias indutoras e intervenção econômica. Rio de Janeiro: Forense, 2005. p. 44.

${ }^{45}$ Id. ibid., p. 46.

${ }^{46}$ Id. ibid., p. 47. 
comportamento de acordo com o respectivo mandamento. Vale dizer: quando não é necessário um efeito absoluto e sem lacunas, tolerando-se que alguns não adotem a conduta indicada, sem com isso implicar uma distorção do objetivo almejado.

Ilustra o referido autor que, no campo da tributação ambiental, muito foi discutido acerca da conveniência de serem adotadas normas de direção ou de indução, tendo prevalecido o entendimento de que seria melhor o emprego de normas tributárias, diretamente vinculadas a atuações prejudiciais ao ambiente (emissões de barulho ou resíduos). A vantagem, sob o ponto de vista econômico, é a de que o instrumento tributário permitiria maior escalonamento, bastando que a redução do tributo se faça proporcionalmente à redução do nível de emissões.

Vale ressaltar, todavia, que tais intervenções podem afetar a liberdade e a igualdade do particular, pelo que o estudo de seus limites será procedido em itens específicos deste trabalho ${ }^{47}$.

Acerca da intervenção estatal na economia realizada na Europa, Cláudia Dias Soares $^{48}$ salienta que os auxílios de Estado consubstanciam o instrumento com possibilidade de ser manejado, em âmbito nacional, com o intuito de proteger a indústria doméstica. A mencionada autora aduz, ainda, que tais auxílios são a expressão mais significativa do poder financeiro do Estado moderno.

Por seu turno, no que tange ao planejamento estatal, o presente trabalho alinha-se, mais uma vez, às lições de Eros Roberto Grau ${ }^{49}$, para quem o "planejamento" não se encontra incluído no rol das modalidades de intervenção. Isto porque o planejamento “apenas qualifica a intervenção do Estado sobre e no domínio econômico, na medida em que esta, quando consequente ao prévio exercício dele, resulta mais racional”.

Assim, considera-se, tal como o mencionado jurista, que a intervenção no domínio econômico e sobre o domínio econômico pode ocorrer de forma planejada ou não, sendo certo que a utilização de um planejamento implicará uma intervenção mais racional ${ }^{50}$.

Deveras, restando evidenciadas as formas de atuação estatal na economia, passa-se a investigar os fundamentos e o contexto em que estas devem ocorrer. Com efeito, serão

\footnotetext{
${ }^{47}$ Ver item 3.4.

${ }^{48}$ SOARES, Cláudia Dias. $O$ direito fiscal do ambiente: o enquadramento comunitário dos auxílios de Estado a favor do ambiente. Coimbra: Almedina, 2003. p. 9.

${ }^{49}$ GRAU, Eros Roberto. A ordem econômica na Constituição de 1988, cit., p. 178.

${ }^{50}$ Id., loc. cit.
} 
desvendadas as razões pelas quais, de há muito, o modelo econômico eminentemente liberal restou abandonado.

\subsubsection{Fundamentos para a atuação estatal na economia}

Ensina o professor Fábio Nusdeo ${ }^{51}$ que a aplicação do chamado figurino liberal por 150 anos trouxe à tona a produção de resultados distanciados do esperado, haja vista que a sua operacionalidade estava na dependência de diversos pressupostos que a estrutura legal própria do liberalismo não havia abordado. Nesse sentido, o mencionado jurista menciona as seis principais falhas do mercado. São elas:

a) Quanto à mobilidade de fatores;

b) Quanto à transparência ou acesso à informação;

c) Quanto à concentração econômica;

d) Quanto aos efeitos externos ou externalidades;

e) Quanto ao suprimento de bens coletivos;

f) Quanto à falha analítica quando os custos de transação são desconsiderados.

O mencionado jurista assinala que a identificação de tais falhas evidencia que a mecânica operacional do mercado corresponde mais a um modelo simplificado do que à realidade que se verifica concretamente. Tal modelo ideal é denominado de concorrência perfeita.

A concorrência perfeita teria palco diante de: a) ampla mobilidade de fatores; b) pleno acesso a informações; c) ausência de economias de escalas, assegurando a presença de grande número quer de vendedores, quer de compradores em cada mercado (a chamada atomização); d) ausência de economias externas (positivas ou negativas); e) exclusividade de todos os bens ${ }^{52}$.

Uma vez que as falhas de mercado ensejam situações em que os pressupostos de funcionamento deste não se fazem presentes, resta abalada a sua operacionalidade. Neste contexto, o temor liberal de que o Estado seria o responsável por ceifar a liberdade é posto

\footnotetext{
${ }^{51}$ NUSDEO, Fábio. Op. cit., p. 139.

${ }^{52}$ Id. ibid., p. 167.
} 
em xeque, haja vista que tal ameaça à liberdade pode ser provocada pela própria imperfeição do mercado ${ }^{53}$.

Assim é que Fábio Nusdeo ilustra a situação em testilha com a seguinte comparação: “À liberdade do poluidor de poluir, corresponde a falta de liberdade da população de respirar ar puro ou de adquirir alimentos não contaminados”. Ou ainda: “O poder do monopolista de provocar a escassez e fixar preços significa a compulsória entrega a ele de parcela extra da renda do consumidor e o tolhimento da liberdade de iniciativa de seus concorrentes menos poderosos" ${ }^{, 54}$.

O Estado é, então, convidado a desenvolver ações, por meio de normas legais e regulamentares, que visam à correção de tais falhas, começando-se a falar em atuação do Estado no domínio econômico, com o fím de reduzir as distorções do sistema ${ }^{55}$.

Portanto, verifica-se que o Estado evolui de um interventor distante para um agente incumbido de apoiar os setores da economia que são insuscetíveis de equacionamento pelo mercado. O Estado agirá em harmonia com o mercado, suprindo-lhe as deficiências, sem lhe tolher as condições de funcionamento. Promoverá, assim, condições de operacionalidade e viabilidade ${ }^{56}$.

Analisando essa reformulação de paradigmas, Luís Eduardo Schoueri ${ }^{57}$ pondera que o Estado intervencionista, longe de constituir repulsa à concepção liberal, figura como evolução deste, haja vista que ambos acreditam no mecanismo de mercado.

Ao abordar a problemática da mobilidade de fatores, sustenta que a premissa de que a oferta e a demanda sempre se ajustam num equilíbrio não se confirma, pois produtores e consumidores podem deixar de se mover na direção indicada pela lógica do mecanismo de mercado. Nesta toada, distingue as formas imediatas e mediatas por meio das quais o Estado pode equalizar as imperfeições do mercado, notadamente no que tange à mobilidade de fatores ${ }^{58}$ :

Do ponto de vista da intervenção estatal, surge ela no sentido de dar a necessária velocidade aos movimentos de crescimento ou redução de oferta e demanda, o que pode dar-se seja pela atuação direta do Estado, como vultoso produtor ou comprador, seja pela sua atuação mediata, quando se cogita de o Estado conduzir os agentes do mercado ao

\footnotetext{
${ }^{53}$ NUSDEO, Fábio. Op. cit., p. 168.

${ }^{54}$ Id., loc. cit.

${ }^{55}$ Id., loc. cit.

${ }^{56}$ Id., loc. cit..

${ }^{57}$ SCHOUERI, Luís Eduardo. Op. cit., p. 73.

${ }^{58}$ Id. ibid., p. 74.
} 
comportamento esperado. À guisa de exemplo, citam-se as tarifas aduaneiras, pelas quais se veiculam normas tributárias indutoras que podem servir de estímulo à mudança de comportamento de produtores ou compradores.

Nesta altura, cumpre avançar na identificação dos fundamentos para a atuação estatal, chamando atenção para o fato de que, a par da atuação corretiva dos mecanismos de mercado pelo Estado, há aquela voltada a concretizar os objetivos da política econômica.

Note-se que as mencionadas atuações irão deter, na classificação de Fábio Nusdeo, caráter negativo (a primeira) e positivo (a segunda), consoante se verifica das primorosas lições abaixo transcritas ${ }^{59}$ :

A primeira dessas duas motivações pode ser vista como de caráter
negativo, por ter como finalidade reparar um mau funcionamento
operacional. A segunda já se apresenta como uma motivação positiva,
almejando implantar novos resultados, melhores ou mais desejáveis, do
que seria de se esperar do desempenho normal do sistema, ainda quando
corrigidas as suas inoperacionalidades maiores. Assim, a presença do
Poder Público na economia deixa de ter apenas por justificação as falhas
do mercado. Uma segunda e extremamente poderosa motivação acoplou-
se à primeira. Decorre das preferências políticas quanto ao desempenho
tout court do sistema, levando o Estado não apenas a complementá-lo,
mas a direcioná-lo deliberadamente em função de fins específicos.

Neste cenário, resta translúcido que, além de uma atuação de caráter negativo, voltada apenas à correção das disfunções do mercado, o Estado se faz presente no sistema econômico, de forma positiva, para cumprir metas e objetivos traçados pela sociedade (mediante órgãos de representação política), garantindo assim o melhor resultado possível.

Vale salientar que, uma vez fixados os alicerces do sistema econômico, cabe traçar direcionamentos, estipulando-se certos fins, para que se construa um padrão de desempenho. Surge aí a política econômica, que corresponde "ao estudo das relações entre certas variáveis sob a ótica de que umas serão meios ou instrumentos para que as outras assumam um determinado valor ou posição"60.

\footnotetext{
${ }^{59}$ NUSDEO, Fábio. Op. cit., p. 168-169.

${ }^{60}$ Id. ibid., p. 171.
} 
Deveras, na elaboração de sua política econômica, o Estado pode valer-se de vários meios e instrumentos, tais como: finanças públicas; instrumentos monetários ou creditícios; instrumentos cambiais; meios de controle direto etc.

Interessa a este estudo a análise dos instrumentos de finanças públicas, notadamente os de cunho fiscal, por intermédio dos quais o Estado buscará influir no comportamento do mercado, criando alterações quantitativas, que irão afetar os preços, tendo como escopo interferir nas decisões dos contribuintes em prol da proteção ambiental.

Com efeito, ao diminuir ou aumentar o custo de produção ou comercialização por meio da utilização desse instrumental, o Estado atua de forma indireta na economia, pois, longe de proibir ou exercer, ele próprio, determinada atividade de forma direta, estará provocando comportamentos dos particulares, tanto no sentido de inibir uma conduta indesejada quanto no de fomentar uma conduta desejada.

De tudo quanto foi exposto no presente item, constata-se que os fundamentos para que o Estado atue no sistema econômico pautam-se pela necessidade de tal ente: i) contornar falhas do mercado e ii) direcionar o mercado em busca de melhores resultados, considerando-se os objetivos traçados pela sociedade.

As considerações até aqui firmadas permitem que se examine, na sequência, a atuação do Estado no manejo de instrumentos econômicos voltados à correção de falhas do mercado - externalidades - e à estruturação de políticas públicas calcadas no princípio da ordem econômica que determina a defesa do meio ambiente.

\subsubsection{A defesa do meio ambiente como princípio da ordem econômica concretizador do desenvolvimento sustentável}

Consoante já pontuado, a defesa do meio ambiente constitui um dos princípios da ordem econômica brasileira. Para Eros Roberto Grau ${ }^{61}$, o princípio veiculado pelo art. 170, VI, é um princípio constitucional do tipo impositivo, segundo classificação do constitucionalista Gomes Canotilho ${ }^{62}$. Este autor português defende que os princípios constitucionais impositivos são aqueles que obrigam os órgãos do Estado, sobretudo o

\footnotetext{
${ }^{61}$ GRAU, Eros Roberto. A ordem econômica na Constituição de 1988, cit., p. 250.

${ }^{62}$ CANOTILHO, José J.G. Direito constitucional e teoria da Constituição. Coimbra: Almedina, 2003. p. 1161.
} 
legislador, à realização de fins e à execução de tarefas. Dinâmicos e prospectivamente orientados, são preceitos definidores do fim do Estado.

Por seu turno, José Afonso da Silva ${ }^{63}$ ressalta que o fato de a defesa do meio ambiente consubstanciar um princípio da ordem econômica implica condicionar a atividade produtiva ao respeito ao meio ambiente e possibilita ao Poder Público interferir drasticamente, se necessário, para que a exploração econômica preserve a ecologia.

Todavia, apesar de prospectivo, o princípio em tela pode ser manejado diretamente, por exemplo, como critério de escolha de determinada empresa licitante. Assim, seria contemplada aquela que provocar, dentre outros atributos, reduzido impacto ambiental com seus produtos ou serviços.

André Ramos Tavares ${ }^{64}$ ressalta que o princípio da defesa do meio ambiente, estabelecido no capítulo da ordem econômica da Constituição, demanda a conciliação entre o desenvolvimento econômico e as medidas preservacionistas, pelo critério de ponderação e proporcionalidade ${ }^{65}$, em vista do caso concreto.

Ilustrando o entendimento do citado autor, pode-se dizer que a norma constitucional que tutela a livre-iniciativa, por exemplo, não permite que determinada atividade produtiva restrinja exageradamente os princípios e as regras que estabelecem a proteção ao meio ambiente, sendo exigido, pois, que o legislador ou qualquer outro aplicador do Direito, dentre eles o Juiz, equacione esse conflito de forma a melhor atender aos diversos bens, princípios e valores colidentes no caso concreto.

Note-se que, inspirado no Protocolo de Quioto, o constituinte derivado, por meio da Emenda Constitucional n. ${ }^{o} 42 / 2003$, houve por bem acrescentar, ao princípio da defesa do meio ambiente (art. 170, VI), a previsão de que este deve ser efetivado "inclusive mediante tratamento diferenciado, conforme o impacto ambiental dos produtos e serviços e de seus processos de elaboração e prestação".

Embora o novo comando inserido pela referida emenda contenha aspecto afirmativo em relação à questão ambiental, não trouxe maiores inovações na matéria, ou seja, um conteúdo inédito à matéria, pois essa possibilidade de ser conferido tratamento diferenciado em face da degradação ambiental já poderia ser extraída do princípio da

\footnotetext{
${ }^{63}$ SILVA, José Afonso da. Op. cit., p. 796.

${ }^{64}$ TAVARES, André Ramos. Direito constitucional econômico. São Paulo: Método, 2006. p. 188.

${ }^{65}$ A proporcionalidade será analisada com vagar no item 3.4.3.
} 
defesa do meio ambiente, preexistente no rol dos princípios norteadores da atividade econômica.

Isto porque, como se sabe, uma das formas de o Estado intervir sobre a economia com base no critério ambiental é justamente desonerando bens e atividades ditas "limpas" e onerando aqueles cujo resultado final ou processo produtivo acabem por impactar de forma mais grave o meio ambiente.

De qualquer modo, num ordenamento jurídico como o brasileiro, ainda muito atado às normas postas, o referido mandamento dispensa qualquer tipo de questionamento acerca da autorização constitucional para a realização de tratamento diferenciado conferido em função do impacto ambiental do bem ou serviço.

Não há dúvidas, entretanto, de que a alteração do texto constitucional em foco demonstra que a preocupação ambiental ganhou ainda mais fôlego com o passar dos anos.

Nesse sentido, tratando-se de norma constitucional que adota critério ambiental como balizador da ordem econômica, não se pode falar, em tese, em afronta à isonomia caso determinado produto extremamente poluente sofra restrições econômicas, tal como limitações no recebimento de subvenções, haja vista que esse tratamento desigual é chancelado pela Lei Maior, devendo ser acolhido, salvo se for considerado desmedido.

Assim sendo, a parte final do art. 170, VI, estabelece que as atividades econômicas não devem ter um fim em si mesmas, mas precisam estar atadas a critérios, notadamente o de conferir tratamento econômico mais severo a bens e serviços que degradam o meio ambiente e tratamento mais favorável àqueles que possuem reduzido impacto ambiental.

Neste espeque, a ideia de "quanto mais, melhor", independentemente da maneira pela qual os bens e serviços são produzidos e dos efeitos deles decorrentes, já não pode ser concebida de forma absoluta diante do que se extrai do conteúdo do mencionado princípio da ordem econômica.

Deveras, o mencionado vetor, ante a inescapável constatação de que os recursos do planeta são finitos e de que a sua capacidade de absorção e regeneração de resíduos é limitada, determina a adoção de tratamentos diferenciados de acordo com o impacto ambiental dos produtos e serviços.

Tal distinção proposta nada mais faz do que admitir que nem toda a riqueza gerada pela atividade econômica resulta em melhoria da qualidade de vida, podendo, ao contrário, 
trazer alto custo para a sociedade, custo este que pode ser neutralizado mediante tratamentos distintos de acordo com os malefícios causados.

De outra parte, os bens e serviços que, além de geração de riqueza, estejam alinhados com os objetivos de preservação ambiental, devem ser fomentados por meio de tratamentos mais benéficos.

Em suma: extrai-se do dispositivo em foco a determinação para que sejam: i) corrigidas as falhas do mercado quanto às externalidades e ii) fomentadas as atividades exercidas com a redução do impacto ambiental. Nesse sentido, caberá ao Estado atuar tanto de forma corretiva (negativa), como ativamente, por meio de políticas econômicas com viés ambiental (positiva).

Quanto às externalidades, estas consubstanciam uma falha no mercado identificada sempre que os custos ou benefícios pertinentes a certa atividade não estiverem computados no seu cálculo econômico.

O pressuposto é o de que tais custos ou benefícios estão sendo absorvidos, quer pelos produtores, quer pelos consumidores dos correlatos bens e serviços, e no instante em que não há esse repasse na dinâmica dos preços, surge uma distorção de sinalização, ou seja, o valor praticado não condiz com a realidade.

Verifica-se, assim, um efeito externo quando as normas existentes não logram identificar e embutir tais custos nos preços. Desse modo, os preços, em si, ficam distorcidos, porém os custos e benefícios são verificados por terceiros (determináveis ou não). Ou seja, o mercado não enxerga as externalidades, entretanto elas são sentidas por aqueles que acabam por arcar com o ônus decorrente de tal distorção.

Neste contexto, uma indústria que elimina efluentes devastadores da fauna e da flora de determinado rio prejudica a sociedade como um todo, e, mais diretamente, aqueles que dependem dos referidos recursos naturais para sobreviver.

Por outro lado, é possível que a sociedade usufrua de um benefício, por força de um efeito positivo externo a certa atividade, hipótese em que se verificará uma externalidade positiva $^{66}$. Exemplo de tal externalidade é o desenvolvimento de técnica de produção que resulta na redução da emissão de gases de efeito estufa quando da fabricação de determinado bem. A sociedade se beneficia com a redução da poluição, porém, em

\footnotetext{
${ }^{66}$ As externalidades ou efeitos externos positivos também podem ser chamados de benefícios sociais quando não se identificam os beneficiários ou quando eles não constituem um grupo definido de indivíduos.
} 
determinadas circunstâncias, nem todas as despesas com a aquisição de maquinário adequado poderão ser incluídas no preço praticado.

Assim, a empresa que não fez os aludidos investimentos e industrializa de forma ambientalmente irresponsável poderá praticar preços mais competitivos do que a empresa que optou por incorrer em despesas em prol de uma produção menos agressiva ao meio ambiente.

Com o objetivo de solucionar a questão das externalidades, Arthur Cecil Pigout elaborou teoria, que restou conhecida como Teoria de Pigout, segundo a qual os instrumentos econômicos deveriam simular um preço a ser incorporado aos custos privados, de modo a serem absorvidas pelo agente econômico as externalidades decorrentes dos correlatos processos produtivos. Segundo a mencionada teoria, a alteração dos custos da produção induziria à busca de um novo ponto de equilíbrio, atingindo-se, pois, o "ótimo de Pareto".

Esclarece Luís Eduardo Schoueri ${ }^{67}$ que, computados os custos pertinentes às externalidades negativas, os preços dos produtos tendem a crescer na mesma proporção, reduzindo-se, por conseguinte, sua demanda, em novo ponto de equilíbrio.

Quanto às externalidades positivas, sustenta o referido jurista ${ }^{68}$ ser cabível a concessão de vantagens econômicas para incrementar os ganhos daqueles que as provocam, permitindo, assim, a contabilização das vantagens geradas.

Observa-se que as externalidades ambientais positivas e negativas existentes de forma oculta na economia consubstanciam falhas de mercado que, desde já, afastam a possibilidade do ideal da concorrência perfeita.

Neste contexto, para cumprir com a função de guardião da operacionalidade do mercado (atuação negativa), cabe ao Estado, detectada tal distorção de sinalização: i) embutir no preço dos bens e serviços que impactam o meio ambiente o custo, até então oculto, que vinha sendo arcado pela sociedade como um todo ou por um grupo determinado, quando se tratar de externalidade negativa; e ii) conceder tratamento econômico mais vantajoso àqueles que produzem bens e serviços "limpos" ou de "forma limpa", no caso de efetiva produção de efeitos externos positivos, que vinham beneficiando

\footnotetext{
${ }^{67}$ SCHOUERI, Luís Eduardo. Normas tributárias indutoras em matéria ambiental. In: TÔRRES, Heleno Taveira (Org.). Direito tributário ambiental. São Paulo: Malheiros, 2005. p. 236.

${ }^{68}$ Id. ibid., p. 25.
} 
a sociedade em geral ou determinado grupo de indivíduos, sem o correlato repasse de tal ganho aos respectivos fornecedores e consumidores.

Considerando o escopo do estudo deste estudo, não será aprofundado o exame da forma e de quanto os custos com externalidades negativas devem ser adicionados aos produtos e serviços desenvolvidos de forma tradicional (sem preocupação ambiental).

Buscar-se-á demonstrar o dever do Estado de intervir sobre a economia, valendo-se de instrumental tributário, para garantir que as externalidades positivas, existentes no âmbito da economia verde ou de baixo carbono, sejam incluídas nos preços dos bens e serviços ambientalmente responsáveis, permitindo, assim, que seus custos sejam reduzidos e que passem a competir no mercado sem a mencionada distorção de sinalização.

O aludido tratamento econômico vantajoso, ao eliminar ou dirimir a existência de benefício social que se encontra fora da realidade do mercado, fomentará, de modo indireto, a migração da economia tradicional para a economia de baixo carbono, na medida em que os investimentos que se façam necessários à redução do impacto ambiental da produção, bens e serviços passarão a estar refletidos nos preços praticados, ou seja, os fornecedores e consumidores, ao produzirem benefícios para terceiros, também serão favorecidos pelo Estado.

Noutros dizeres: os consumidores e os fornecedores, que contribuem para a produção de efeitos positivos de cunho ambiental deixarão de financiar sozinhos tais benefícios usufruídos por terceiros, porquanto o Estado equalizará os custos envolvidos, por meio de incentivos fiscais.

A esse respeito, insta mencionar a postura do governo britânico, que assume papel de protagonista na consecução de objetivos para a melhoria dos indicadores do desenvolvimento sustentável, ao reputar que a melhor forma para o atingimento desse escopo ocorre mediante o emprego dos instrumentos de política econômica e fiscal que estão nas mãos dos poderes públicos. Para o referido ente, isto se deve ao fato de que o mercado por si só não pode dar solução a tais problemas, já que apresenta falhas em seu funcionamento, dentre eles, a externalidade ${ }^{69}$.

${ }^{69}$ FERNÁNDEZ DE TROCÓNIZ ROBLES, Borja. La tributación medioambiental en Gran Bretaña. In: BECKER, Fernando; CAZORLA, Lui Maria; MARTÍNEZ-SIMANCAS, Julián (Dir.). Tratado de tributación medioambiental. Pamplona: Aranzandi, 2008. v. 2, p. 936. 
Borja Fernández de Trocóniz Robles ${ }^{70}$ assevera que a externalidade, dentro da teoria econômica, configuraria situação em que um agente econômico se vê beneficiado ou prejudicado como resultado de uma atuação de outro agente econômico, sem pagar pela vantagem ou ser compensado pelo dano. No caso do meio ambiente, grande parte das externalidades é negativa. Assim, caso não sejam identificados mecanismos para que aqueles que agridem o meio ambiente em decorrência de sua atividade produtiva tenham estes danos incorporados na sua estrutura de custos, os agentes que ocasionam as externalidades negativas nunca se verão motivados a modificar sua atuação.

Da mesma maneira, o aludido autor aduz ser possível, por meio de deduções e isenções, premiar agentes de mercado que respeitam ou protegem a natureza, compensando as externalidades positivas.

Firmado, pois, que o Estado está autorizado a lançar mão de instrumentos fiscais como forma de atuar na economia como agente responsável por corrigir a falha de mercado relativa às externalidades positivas na produção, nos produtos e nos serviços verdes (dimensão negativa), cabe abordar, especificamente, os fundamentos que embasam o uso de tais ferramentas como maneira de direcionar a economia a fim de concretizar o princípio da defesa do meio ambiente (dimensão positiva).

Com efeito, já restou assentado que atrelada à atuação corretiva estatal sobre a economia, de cunho negativo, existe uma de motivação positiva, que visa a alcançar novos resultados, tidos como melhores do que os que seriam experimentados se a economia estivesse a funcionar normalmente.

Nesta perspectiva, ainda que não se constatasse a existência de disfunções do mercado provocada pelas externalidades ambientais acima referidas, a demandarem medidas corretivas adotadas pelo Estado, cumpriria ao ente estatal desenvolver políticas econômicas voltadas à promoção da defesa do meio ambiente, por meio de instrumentais econômicos, incluindo os veículos tributários.

Noutras palavras, a presença do Estado na economia, com o fim de efetivar a proteção ambiental, a teor do art. 170, VI, da CF/1988, tem fundamentação dúplice, porquanto pode ser realizada para a correção de externalidades (positivas e negativas) ou para a criação de medidas que fomentem políticas públicas e atividades alinhadas ao objetivo de manutenção, reparação e proteção ambiental.

\footnotetext{
${ }^{70}$ FERNÁNDEZ DE TROCÓNIZ ROBLES, Borja. Op. cit., p. 936-937.
} 
Tais políticas públicas estariam ajustadas aos desígnios constitucionais, pois, além de o seu texto albergar, nos mais diversos capítulos e seções, a menção à questão ambiental, há dispositivo específico inserido no rol dos princípios da ordem econômica que determina a "defesa do meio ambiente, inclusive mediante tratamento diferenciado conforme o impacto ambiental de produtos e serviços e de seus processos de produção".

Portanto, dúvidas não há quanto à adequação de política econômica que vise ao desenvolvimento nacional, mas que não se contente com um crescimento tradicional, cabendo ser estabelecido como meta, além da elevação do PIB, o incremento de vínculos formais e o aumento das exportações, a obtenção de ganhos de caráter ambiental.

Eros Roberto $\mathrm{Grau}^{71}$ já teve a oportunidade de pontuar que o desenvolvimento pressupõe dinâmicas mutações, não se limitando a um crescimento econômico em termos quantitativos, sendo necessário que se experimente um crescimento qualitativo, proporcionado, por exemplo, pela introdução de novas matérias-primas e novas formas de produção.

Ressalte-se trecho em que evidencia que o crescimento econômico é apenas uma parcela da noção de desenvolvimento ${ }^{72}$ :

O desenvolvimento supõe não apenas crescimento econômico, mas, sobretudo, elevação do nível cultural-intelectual comunitário e um processo, ativo, de mudança social. Daí porque a noção de crescimento pode ser tomada apenas e tão somente como uma parcela da noção de desenvolvimento. O desenvolvimento, como já apontava Schumpeter (Teoría del Desenvolvimento Económico, trad. de Jesus Prados Ararte, Fondo de Cultura Económica, México, 1967, p.74), se realiza no surgimento de fenômenos econômicos qualitativamente novos - isto é, de inovação - consequentes à adoção de novas fontes de matéria-prima, de novas formas de tecnologia, de novas formas de administração da produção etc. Já o crescimento é demonstrado pelo incremento da população e da riqueza; implica apenas mudança nos dados quantitativos. Daí porque, nos conceitos formulados de desenvolvimento, sempre aparece como nota marcante uma referência a este seu aspecto qualitativo. De outra parte, embora o dado econômico apareça como extremamente relevante em todos os conceitos de desenvolvimento, ainda assim é forçoso observar que o conceito de desenvolvimento não é apenas econômico. O processo de desenvolvimento - vimos já - implica mobilidade e mudança social; realiza-se em saltos de uma estrutura social para outra. Implicando dinâmica mobilidade social, é inerente a ideia de desenvolvimento a de mudança; no caso, não apenas mudança econômica, mas, amplamente, sobretudo, mudança social. Assim, a noção de desenvolvimento envolve a necessária visualização de um devir a projetar, no futuro, determinados valores.

${ }^{71}$ GRAU, Eros Roberto. Elementos de direito econômico. São Paulo: RT, 1981. p. 7-8.
${ }^{72}$ Id. Ibid., p. 7-8. 
Resta claro que o desenvolvimento nacional de que trata o art. 3. ${ }^{\circ}$, II, da Lei Maior não está a se referir apenas ao incremento econômico quantitativo, extraído do sistema econômico tradicional. Necessário que o crescimento venha acompanhado por mudanças a resultar numa evolução, seja ela tecnológica, seja ela social ou em outro campo da realidade.

Voltando-se para a seara ambiental, nota-se que uma política pública responsável por aquecer a atividade econômica e atingir um crescimento nominal já não é suficiente, sendo indispensável que se tenha um incremento sustentável, equacionando-se o crescimento com os limites impostos pelas condições de sobrevivência do homem no planeta. Afinal, o crescimento inconsequente só abrevia esse limite de longevidade.

Portanto, a interpretação que se tem de desenvolvimento, tal como estipulado pela Carta Política de 1988, é a de que este não possui um fim em si mesmo, sendo, pois, perseguida uma evolução sustentável, responsável por viabilizar a própria continuidade do crescimento ao longo do tempo.

Neste compasso, na busca por um desenvolvimento sustentável, o ente Estatal deve desenvolver políticas públicas que permitam a sua concretização, mediante o fomento, por exemplo, de transformações no modo de produção voltadas à redução dos impactos ambientais.

Jorge Soto $^{73}$, ao versar sobre as formas pelas quais as mudanças rumo a uma produção mais sustentável podem ser aceleradas, assinala que o governo possui papel indutor, defendendo que "Os primeiros a se movimentarem devem ser incentivados. A introdução de novas tecnologias, normalmente, traz riscos e ocorre em escala de produção frequentemente menor que os produtos existentes. Isso encarece as novas soluções. Incentivos na forma de financiamentos mais baratos ou de menores tributos podem facilitar esse processo inovativo".

Note-se, ainda, que a questão da sustentabilidade está presente na realidade atual, acompanhando os atos praticados pelo ser humano; portanto, longe de colidir com os demais fundamentos da ordem econômica, é possível que se promova um ajuste em todos eles, de modo que o tratamento financeiro e econômico diferenciado relativo a bens,

\footnotetext{
${ }^{73}$ SOTO, Jorge. A química sustentável: desafios, dilemas e perspectivas. In: ALMEIDA, Fernando (Org.). Desenvolvimento sustentável 2012 - 2050: visão, rumos e contradição. Rio de Janeiro: Elsevier, 2012. p. 234.
} 
produtos e produção de baixo impacto ambiental possa conjugar-se às mais diversas políticas econômicas instituídas.

Assim, por exemplo, ao oferecer estímulo financeiro à indústria automobilística, diante de uma crise econômica, cabe aos governos moldar tal incentivo de maneira a privilegiar com mais ênfase veículos movidos a biocombustíveis e dotados de maior eficiência energética.

Da mesma forma, ao buscar incrementar os vínculos formais de emprego, caberia a criação de variados instrumentos econômicos, dentre eles, a concessão de crédito com taxa de juros bonificada, a ser praticada, preferencialmente, com empresas que, por exemplo, ofereçam cursos na área de sustentabilidade, possuam política e setor específico dedicado à sustentabilidade, adotem relatório integrado, que abarca dados de cunho financeiro, de governança corporativa e ambiental.

Nesta toada, a Instrução Normativa n. ${ }^{\circ}$ 1, de 19 de janeiro de 2010, do Ministério do Planejamento, Orçamento e Gestão, representou importante iniciativa no que tange às compras governamentais, porquanto instituiu as compras sustentáveis no âmbito do Poder Executivo Federal ${ }^{74}$.

Ato contínuo, no final daquele ano, a Lei n. ${ }^{0}$ 12.349/2010 promoveu alteração na Lei n. ${ }^{\circ}$ 8.666/1993, que disciplina as licitações e contratos administrativos, para incorporar, no seu art. $3 .^{\circ}$, critérios de sustentabilidade nas mencionadas contratações. Ressalte-se a dicção do dispositivo em apreço: “A licitação destina-se a garantir a observância do princípio constitucional da isonomia, a seleção da proposta mais vantajosa para a administração e a promoção do desenvolvimento nacional sustentável [...]”.

Com efeito, essa alteração positivou as compras públicas sustentáveis nas licitações, propiciando, num certame, a vitória de empresa que, além de todos os requisitos normativos, ofereça produtos e serviços "limpos", de sorte a promover o desenvolvimento nacional sustentável.

Por sua vez, o Decreto n. ${ }^{\circ} 7.746 / 2012$, que regulamenta o mencionado dispositivo, foi anunciado às vésperas da Rio +20 . Em tal ato normativo restou consignado a título de diretrizes de sustentabilidade: menor impacto sobre recursos naturais como flora, fauna, ar,

\footnotetext{
74، Art. $1 .^{\circ}$ Nos termos do art. $3 .^{\circ}$ da Lei n. ${ }^{\circ} 8.666$, de 21 de junho de 1993 , as especificações para a aquisição de bens, contratação de serviços e obras por parte dos órgãos e entidades da administração pública federal direta, autárquica e fundacional deverão conter critérios de sustentabilidade ambiental, considerando os processos de extração ou fabricação, utilização e descarte dos produtos e matérias-primas."
} 
solo e água; preferência para materiais, tecnologias e matérias-primas de origem local; maior eficiência na utilização de recursos naturais como água e energia; maior geração de empregos, preferencialmente com mão de obra local; maior vida útil e menor custo de manutenção do bem e da obra; uso de inovações que reduzam a pressão sobre recursos naturais; e origem ambientalmente regular dos recursos naturais utilizados nos bens, serviços e obras etc.

Insta pontuar a importância de tal Decreto, considerando que as compras do governo representam 16\% do Produto Interno Bruto (PIB).

Ainda sob o impacto da citada Conferência Internacional, foi noticiada a concessão, pela FINEP - Financiadora de Estudos e Projetos, empresa pública vinculada ao Ministério de Ciências, Tecnologia e Inovação, de nova linha de crédito, de cerca de R\$ 1,5 bilhão, para as empresas financiarem as operações baseadas em projetos de inovação na área de eficiência energética e ambiental ${ }^{75}$.

Tal órgão também irá conceder subvenção, estimada em R\$ 500 milhões, aos institutos federais e universidades que apoiarão as companhias na implementação de seus projetos.

O escopo do programa de concessões de crédito (reembolsáveis ou não) é apoiar o desenvolvimento de produtos, processos e serviços inovadores que contemplem de modo integrado os aspectos sociais, ambientais e econômicos, ganhando destaque os seguintes temas: energias renováveis/biocombustíveis, eficiência energética, mobilidade e transportes urbanos sustentáveis, combate aos efeitos das mudanças climáticas, do efeito estufa ou de poluentes, produção sustentável (produção mais limpa, ecodesign etc.), reciclagem de resíduos e saneamento ambiental, construções e infraestrutura urbana sustentável, biodiversidade e preservação de ecossistemas, cadeias da sociobiodiversidade, veículos elétricos e/ou híbridos etc.

Como se vê, o comando sob análise pode consubstanciar uma norma jurídica inspiradora de regras que adotam o tratamento diferenciado segundo o impacto ambiental de bens e serviços, bem assim tem condições de incidir diretamente na regulação das condutas, figurando, de tal modo, como uma norma jurídica disciplinadora de comportamentos.

\footnotetext{
${ }^{75}$ FINEP - Brasil sustentável. Disponível em: $<$ http://www.finep.gov.br/pagina.asp?pag=25.12>. Acesso em: 20 nov. 2012.
} 
De fato, os estímulos ao consumo de produtos que consomem menos energia, a tributação diferenciada de acordo com critério ambiental, bem como a concessão de financiamentos a empresas sustentáveis são exemplos de instrumentos que conferem concretude ao mandamento contido na parte final do art. 170, VI, da Lei Maior.

Vale alertar, todavia, que caberá aos aplicadores do Direito avaliar os limites das respectivas normas, porquanto a diretriz em foco não constitui uma carta branca, por exemplo, para restrição ou concessão desenfreada de estímulos financeiros aos bens ditos mais "limpos", devendo as respectivas atuações do Poder Público estar ajustadas aos demais bens, valores e interesses tutelados pelo ordenamento jurídico pátrio.

Considerando que o trabalho ora em pauta se propõe a analisar os limites e parâmetros à concessão de incentivos fiscais ambientais, que consubstanciam estímulos à redução do impacto ambiental conferidos pelo Estado, por intermédio de instrumentos tributários, examinaram-se acima as formas e fundamentos mediante os quais o Estado possui autorização para atuar na economia em prol da causa ecológica.

Buscou-se, até então, situar a mencionada intervenção do Estado dentro do contexto da ordem econômica e do direito econômico, para, na sequência, empreender a sua análise de forma mais aprofundada, no âmbito tributário, notadamente na seara da extrafiscalidade. É o que será abordado no próximo Capítulo. 


\section{TRIBUTAÇÃO E PROTEÇÃO DO MEIO AMBIENTE}

\subsection{A tributação na vida social e econômica do Brasil}

A tributação é condição para a própria sobrevivência do Estado, sendo inerente a tal ente o poder que este detém de exigir que seus membros, dentro das suas capacidades ${ }^{76}$, arquem com as despesas contraídas para a satisfação das necessidades coletivas.

Com efeito, o tributo irá consubstanciar a parcela da riqueza particular que é destinada ao Estado para que este detenha recursos financeiros para concretizar os objetivos plasmados na Constituição.

Nota-se, assim, que a exação fiscal corresponde a um gravame que recai sobre o direito de propriedade daqueles que optam por pertencer a determinada sociedade. Dessa maneira, a destinação de parte de bens ao Estado corresponde ao ônus que se tem por participar dessa estrutura organizacional.

Para o Estado, o tributo constitui meio de obter fonte de receita indispensável à consecução dos fins para cuja realização ele nasce e se conserva ${ }^{77}$.

Com efeito, a soma de recursos que cada contribuinte deve arcar para custear os gastos do Estado é definida, ao longo da história, a partir das opções políticas adotadas por cada sociedade. Neste compasso, resta evidente que a intensidade da imposição fiscal é inerente ao cenário em que ela está inserida.

Sob tal prisma, o estudo da tributação de um país irá demandar a análise, dentre outros aspectos, do modelo de Estado adotado.

Nos primórdios do regime capitalista, os países optaram por adotar o modelo econômico liberal, baseados na teoria econômica clássica, cuja noção dominante seria a da máxima liberdade econômica, seja das empresas, seja dos consumidores ${ }^{78}$.

\footnotetext{
${ }^{76}$ A Constituição brasileira de 1824 já consignava em seu texto a norma segundo a qual "ninguém será isento de contribuir para as despesas do Estado em proporção aos seus haveres” (art. 179, n. ${ }^{\circ} 15$ ).

${ }^{77}$ VANONI. Natureza e interpretação das leis tributárias. Rio de Janeiro: Financeiras, [s.d.]. p. 133, apud TORRES, Ricardo Lobo; SCHOUERI, Luís Eduardo; ZILVETI, Fernando Aurélio (Coord.). Direito tributário: estudos em homenagem a Brandão Machado. São Paulo: Dialética, 1998. p. 195.

${ }^{78}$ ELALI, André. Incentivos fiscais internacionais: concorrência fiscal, mobilidade financeira e crise do Estado. São Paulo: Quartier Latin, 2010. p. 131.
} 
Pautava-se a tese liberal pela ideia de neutralidade do Estado, havendo a segregação entre finanças públicas e economia, e, por conseguinte, a demanda pela neutralidade tributária. De tal sorte, não poderia a tributação alterar os preços do mercado, a produção, a distribuição de riqueza e a alocação de recursos ${ }^{79}$.

Todavia, com a crise do liberalismo clássico, o Estado passa a adquirir papel de relevo no controle e na fiscalização dos agentes econômicos e na proteção dos direitos sociais relevantes. A multiplicação de políticas fiscais, dentre elas as que concediam incentivos fiscais, trouxe à tona a discussão acerca da neutralidade tributária. Uma vez que o Estado passou a intervir no mercado para evitar as chamadas falhas de seus mecanismos e para a promoção do Estado de Bem-Estar Social, restou descabido falar em neutralidade tributária e abstinência estatal na economia ${ }^{80}$.

Expondo as lições do financista alemão Neumark, o mestre Aliomar Baleeiro ${ }^{81}$ ressalta que a tributação, principalmente no pós-guerra, passa a exercer efeitos sobre a estrutura social, de modo que as "finanças neutras" corresponderiam a resultados aleatórios. Assim, a tributação consiste num instrumento de política social, econômica e demográfica, o qual, todavia, encontra-se adstrito aos fins a que se presta.

No Brasil, a Carta Política de 1988 conferiu papel de relevo ao Estado, atribuindolhe a missão de assegurar inúmeros direitos individuais, sociais e econômicos, bem como de efetivar a justiça material. Nesta perspectiva, como alguns dos seus objetivos primordiais, acham-se a construção de uma sociedade livre, justa e solidária, a erradicação da pobreza e a redução das desigualdades sociais (art. 3. ${ }^{\circ}$ da CF de 1988).

No seu art. 1. ${ }^{\circ}$ erigiu como fundamentos da República Federativa do Brasil, dentre outros, a dignidade da pessoa humana, os valores sociais do trabalho e da livre- iniciativa, bem como assegurou, nos arts. $5^{\circ}$ e $6 .^{\circ}$, aos residentes no país, como direito fundamental, o direito à vida, à liberdade, à segurança, à educação, à saúde, à moradia, ao lazer e à segurança.

Em face deste robusto leque de prestações positivas e de uma multiplicidade de diretrizes espraiadas ao longo do texto Constitucional de 1988, construiu-se no Brasil não apenas um Estado Democrático de Direito, lastreado na soberania popular e nas

\footnotetext{
${ }^{79}$ ELALI, André. Op. cit., p. 132.

${ }^{80}$ Id. Ibid., p. 133.

${ }^{81}$ BALEEIRO, Aliomar. Uma introdução à ciência das finanças. 14. ed. Rio de Janeiro: Forense, 1987. p. 182.
} 
instituições democráticas, mas um verdadeiro Estado Social, baseado na síntese dualista do bem-estar social e do desenvolvimento econômico.

Ao contemplar normas que salvaguardam os direitos sociais e conformam a economia, a Lei Maior chancelou, de modo inequívoco e definitivo, a atuação estatal nestes campos, distanciando-se, portanto, do Estado Liberal, abstencionista.

Entretanto, a referida opção política por um Estado Democrático de caráter Social produz efeito direto na tributação, já que o conjunto de medidas a serem executadas pelo Estado e os objetivos postos em prol da coletividade demandam importante transferência de recursos para o erário. A referida transferência é justificada pelo dever de solidariedade, extraído do art. 3. ${ }^{\circ}$ da Constituição, que determina a construção de uma sociedade livre, justa e solidária.

Todavia, a autorização para interferir na esfera individual não é ilimitada, haja vista que a Carta Política também contemplou a proteção dos direitos individuais clássicos, como a liberdade e a propriedade privada.

Cumpre asseverar que, quando se opta por um constitucionalismo social, tal como foi feito pelo constituinte de 1988, inevitável se torna a tensão entre os mais diversos interesses que são tutelados, sendo inerente o conflito entre a proteção a direitos individuais e o dever de solidariedade, admitindo-se a busca de recursos particulares para fazer face às despesas incorridas pelo Estado.

Para balizar a tensão acima destacada, a Lei Maior cuidou de definir normas de competência e limitações ao poder de tributar. Delineou-se, de modo minudente, o campo de competência outorgado a cada ente arrecadante, sendo discriminadas todas as exações passíveis de ser instituídas e a forma a ser observada por cada pessoa política.

Desse modo, a União, os Estados e os Municípios, que, em virtude da forma federativa de Estado adotada, foram designados como sujeitos ativos da relação tributária, tiveram seu âmbito de atuação delimitado pela Lei Maior, primordialmente, por meio de regras jurídicas que cuidam de fixar taxativamente os limites da intervenção na esfera individual. 
Nota-se, portanto, que a competência tributária consiste numa permissão atrelada a uma limitação constitucional, a que o ente tributante está adstrito para exercitar o poder tributário. Sobre o assunto, leciona Paulo de Barros Carvalho ${ }^{82}$ :

Competência legislativa é a aptidão de que são dotadas as pessoas políticas para expedir regras jurídicas inovando o ordenamento positivo. Opera-se pela observância de uma série de atos, cujo conjunto caracteriza o procedimento legislativo.

Por força do princípio da legalidade (CF, art. 5. ${ }^{\circ}$, II), a ponência de normas jurídicas inaugurais no sistema há de ser feita, exclusivamente, por intermédio de lei, compreendido este vocábulo no seu sentido lato. Em qualquer segmento da conduta social, regulada pelo direito, é a lei o instrumento introdutor dos preceitos jurídicos que criam direitos e deveres correlatos.

No plexo de faculdades legislativas que o constituinte estabeleceu, figura a de editar normas que disciplinem a matéria tributária, desde a que contemple o próprio fenômeno da incidência até aquelas que dispõem a propósito de uma imensa gama de providências, circundando o núcleo da regra-matriz e que tornam possível a realização concreta dos direitos subjetivos de que é titular o sujeito ativo, bem como os deveres cometidos ao sujeito passivo.

A competência tributária, em síntese, é uma das parcelas entre as prerrogativas legiferantes de que são portadoras as pessoas políticas, consubstanciada na possibilidade de legislar para a produção de normas jurídicas sobre tributos.

Salienta o professor José Souto Maior Borges que, apesar de a competência tributária emanar do poder de tributar, com este não se identifica, exemplificando que, no caso brasileiro, a União possui competência para legislar sobre normas gerais de direito tributário, aplicáveis a todos os entes públicos (art. 146 da Lei Maior), embora não detenha o poder de tributar pessoas, bens, atos, fatos ou estados de fatos submetidos à competência tributária privativa dos Estados-membros, do Distrito Federal e dos Municípios ${ }^{83}$.

Cumpre pontuar, ainda no que concerne à contenção ao poder de tributar, que a Carta Política houve por bem estipular inúmeros regramentos e princípios que afastam, por exemplo, a tributação instituída em desacordo com a capacidade contributiva, isonomia, legalidade, anterioridade e não confisco, ou ainda, que diga respeito a bens, pessoas e fatos imunes.

\footnotetext{
${ }^{82}$ CARVALHO, Paulo de Barros. Curso de direito tributário. 23. ed. São Paulo: Saraiva, 2010. p. 217-218.

${ }^{83}$ BORGES, José Souto Maior. Teoria geral da isenção tributária. 3. ed. São Paulo: Malheiros, 2001. p. 30 .
} 
De tal sorte, dúvidas não há quanto à necessidade de o ente arrecadante estar adstrito às rígidas limitações estabelecidas pelo constituinte de 1988.

Ademais, num Estado que é regido pelo Direito e é democrático, a tributação, além de ter de se submeter aos requisitos formais e materiais inerentes a um Estado de Direito, precisa, no plano concreto, estar voltada à construção de uma sociedade livre, justa e solidária, para ser coerente com o seu viés democrático.

Portanto, inescapável é a conclusão de que o ente arrecadante, ao instituir uma exação fiscal, deverá cuidar para que esta se revele ajustada aos mais variados princípios e fins constitucionais.

\subsection{Extrafiscalidade e normas tributárias indutoras}

Tradicionalmente, a doutrina designa de função fiscal aquela cujo foco reside na coleta e concretização das receitas tributárias. De tal modo, quando o Estado exerce seu poder de tributar, de acordo com uma determinada carga média aplicada indistintamente a toda a coletividade, atua "fiscalmente". Entretanto, ao reduzir tal atividade de forma setorial, voltando-se a estímulo específico a certa atividade, grupo ou valor juridicamente protegido, como a cultura ou o meio ambiente, convencionou-se denominar de função "extrafiscal" ou "extrafiscalidade" 84 .

A tributação evoluiu, pois, de uma acepção puramente arrecadatória (fiscalidade) para a ideia de que deve ser manejada de forma a possibilitar a concretização dos mais variados objetivos sociais, econômicos e políticos postos pela Constituição (extrafiscalidade). Assim, o tributo, além de ser tido como principal meio de obtenção de receitas para os cofres públicos, é concebido como importante instrumento de intervenção estatal sobre a conduta dos particulares em prol do desenvolvimento e da melhoria das condições de vida da sociedade.

Observa Luís Eduardo Schoueri ${ }^{85}$ que a acepção de extrafiscalidade traz em seu bojo todo um conjunto de funções da norma diversa da mera fiscalidade, sendo mister, contudo, que se identifique, além da função arrecadadora e da extrafiscal, a categoria simplificadora. Esta última categoria é regida pelo princípio da praticabilidade, que

\footnotetext{
${ }^{84}$ NOGUEIRA, Barbosa, Ruy. Curso de direito tributário. 7. ed. São Paulo: Saraiva, 1986. p. 200.
}

${ }^{85}$ SCHOUERI, Luís Eduardo. Normas tributárias indutoras e intervenção econômica, cit., p. 32. 
permite a adoção de medidas globais, generalizantes, com o escopo de simplificar o sistema tributário. O aludido jurista traz como exemplo a introdução da sistemática do lucro presumido na legislação do Imposto de Renda, que busca a simplificação da apuração do tributo ${ }^{86}$.

Fincadas as funções da norma tributária (fiscal, extrafiscal e simplificadora), conclui o mencionado autor que a extrafiscalidade é um gênero que abarca todos os casos não vinculados à distribuição equitativa da carga tributária ou à simplificação do sistema tributário. Nessa senda, o gênero em foco incluiria as normas com a função indutora (que seria a extrafiscalidade em sentido estrito) e aquelas que também se moveriam por razões não fiscais, porém desatreladas da citada busca pelo impulso econômico por parte do Estado $^{87}$.

Sob o enfoque amplo do conceito de extrafiscalidade, vale registrar a posição de Fábio Fanucchi ${ }^{88}$, para quem há tributo extrafiscal quando se identificam, na sua cobrança, “outros interesses que não sejam os de simples arrecadação de recursos financeiros”, exteriorizados mediante "alívios" e "agravamentos fiscais".

Enrico de Mita $^{89}$ defende que no âmbito da extrafiscalidade o Estado não busca tanto a receita, mas outros fins com relação aos quais o tributo adquire perfil instrumental. Assim, a estrutura ordinária do tributo é modificada em vista do objetivo político que se pretende alcançar.

Quando o Estado pretende desestimular certa atividade, aumentando a carga tributária sobre esta, o objetivo da lei tributária é alcançado exatamente quando não há a sua aplicação ${ }^{90}$.

\footnotetext{
${ }^{86}$ Verifica-se, no país, a proliferação da figura da substituição tributária. Por meio do regime da substituição tributária, a responsabilidade pelo imposto devido em relação às operações ou prestações de serviços é atribuída a outro contribuinte. As referidas substituições buscam concentrar a extinção da obrigação tributária num reduzido número de contribuintes. O objetivo é, pois, evitar a pulverização, para facilitar a fiscalização.

${ }^{87}$ SCHOUERI, Luís Eduardo. Normas tributárias indutoras e intervenção econômica, cit., p. 32. Ressalta Luís Eduardo Schoueri a distinção feita por Von Arnim entre as normas tributárias indutoras e aquelas referentes à política social. Estaria incluída na última categoria, por exemplo, uma legislação que assegurasse tratamento diferenciado em caso de desemprego. Tal caso decorre de aspiração social; contudo, o único efeito seria a melhora da situação do beneficiário, sem por isso consubstanciar um incentivo a que a situação desafortunada permaneça.

${ }^{88}$ FANUCCHI, Fábio. Curso de direito tributário brasileiro. São Paulo: Resenha Tributária, 1976. p. 54.

${ }^{89}$ MITA, Enrico de. O princípio da capacidade contributiva. In: FERRAZ, Roberto Catalano Botelho (Coord.). Princípios e limites da tributação. São Paulo: Quartier Latin, 2005. p. 247-248.

${ }^{90}$ Id., loc. cit.
} 
Por seu turno, na política econômica e, sobretudo, em outros campos (assistência, instrução, cultura, esporte etc.), é possível a aplicação do tributo com a função de estímulo, de incentivo. Neste âmbito, as formas de tributação introduzem tratamento excepcional em relação àquele que é estipulado regularmente.

Para o aludido professor da Universidade Católica de Milão, há diversos patamares de estímulo. Ressalte-se a sua lição ${ }^{91}$ :

\begin{abstract}
A forma plena de estímulo é a isenção, a qual consiste numa norma excepcional que subtrai à tributação pessoas ou bens que deveriam ser tributados segundo a regra. Uma forma atenuada de estímulo é a redução de alíquota. Pode haver regimes substitutivos do regime ordinário, consistentes em esquemas de tributação simplificados - na maioria dos impostos únicos - que substituem com precisão todos os impostos que deveriam incidir sobre uma certa riqueza como a renda.
\end{abstract}

Insta pontuar que a maior parte da doutrina, ao conceituar extrafiscalidade, atém-se à espécie do gênero extrafiscalidade, ou seja, traz a acepção da extrafiscalidade no sentido estrito (normas tributárias de função indutora), excluindo-se, dessa noção, as normas tributárias que buscam a concretização de fins constitucionais, embora não busquem estimular condutas que repercutam no âmbito social e econômico ${ }^{92}$.

Assim, Casalta Nabais ${ }^{93}$, ao versar sobre normas tributárias com o viés extrafiscal, salienta o seu "intuito de actuar directamente sobre os comportamentos económicos e sociais dos seus destinatários".

Nessa esteira, defende Roque Carrazza" que "há extrafiscalidade quando o legislador, em nome do interesse coletivo, aumenta ou diminui as alíquotas e/ou bases de cálculo dos tributos, com o objetivo principal de induzir os contribuintes a fazer ou deixar de fazer alguma coisa".

\footnotetext{
${ }^{91}$ MITA, Enrico de. Op. cit., p. 248.

${ }^{92}$ Seguindo as lições do Professor Schoueri, defende André Elali que a extrafiscalidade pode ser concretizada mediante as chamadas normas tributárias indutoras, seja por meio de incentivos (isenções, reduções tributárias, atribuição de créditos tributários, de regimes especiais e/ou preferenciais etc.), seja por meio de agravamentos tributários (Incentivos fiscais internacionais: concorrência fiscal, mobilidade financeira e crise do Estado, cit., p. 57).

${ }^{93}$ NABAIS, José Casalta. O dever fundamental de pagar impostos: contributo para a compreensão do estado fiscal contemporâneo. Coimbra: Almedina, 1998. p. 629.

${ }^{94}$ CARRAZZA, Roque Antonio. Curso de direito constitucional tributário. 22. ed. São Paulo: Malheiros, 2004. p. 62.
} 
Por seu turno, Misabel Derzi ${ }^{95}$ afirma que "a doutrina e a jurisprudência têm reconhecido ao legislador tributário a faculdade de estimular ou desestimular comportamentos, por meio de uma tributação progressiva ou regressiva, ou da concessão de benefícios e incentivos fiscais".

Também ressaltando o aspecto indutivo de comportamentos, Eduardo Bottallo ${ }^{96}$ enfatiza a relevância adquirida pelos tributos ante a difusão da extrafiscalidade, nos seguintes termos: "dentro deste contexto indutivo de que o Estado deve valer-se para fazer com que os agentes econômicos privados se orientem para atender a fins que ele próprio estabelece, o tributo aparece como figura de grande importância”.

Tecidas essas considerações, cumpre sobrelevar, pela sua importância, que não é peculiaridade da norma extrafiscal a concretização de desígnios constitucionais, haja vista que toda norma jurídica deve atender a tal requisito, por força do princípio da supremacia das normas constitucionais.

De tal sorte, mesmo as normas tributárias voltadas aos fins arrecadatórios estão a contemplar comando insculpido na Lei Maior, sendo impossível se afastar, assim, da constatação de que as normas tributárias são fiscais e extrafiscais, simultaneamente.

O que se constata é a existência de normas tributárias com predominância do viés arrecadatório e de normas tributárias cujo enfoque estaria mais voltado à realização de outro fim constitucionalmente tutelado. São exemplos destas últimas: o apoio aos contribuintes que contraíram moléstia grave (mediante a desoneração, em determinadas situações, da carga fiscal suportada), o aumento da produção cultural no país (por meio de incentivos fiscais à cultura) e a redução do consumo do tabaco (pela maior tributação do consumo deste).

Nessa mesma trilha, Marcus de Freitas Gouvêa ${ }^{97}$ aduz que, no âmbito da extrafiscalidade, a tributação fará com que o Estado obtenha "efeitos econômicos, políticos e sociais, na busca de fins que lhes são impostos pela Constituição”. E adiante, assevera que “[...] extrafiscal é a norma voltada à realização de valores constitucionais. Como não se pode conceber norma jurídica avessa a valores constitucionais, nem norma tributária

95 DERZI, Misabel Abreu Machado. Nota de atualização a Aliomar Baleeiro. Direito tributário brasileiro. 11. ed. Atualizada por Mizabel Abreu Machado Derzi. Rio de Janeiro: Forense, 2003. p. 233.

${ }^{96}$ BOTTALlO, Eduardo Domingos. Mesa de Debates C. Tributação, Ecologia e Meio Ambiente. (XIII Congresso Brasileiro de Direito Tributário). Revista de Direito Tributário, São Paulo, n. 78, p. 70, 1999.

97 GOUVÊA, Marcus de Freitas. A extrafiscalidade no direito tributário. Belo Horizonte: Del Rey, 2006. p. 47. 
avessa a arrecadação, concluímos que toda norma tributária será, a um tempo, fiscal e extrafiscal".

Embora defenda que toda norma tributária é dotada de fiscalidade e extrafiscalidade, pondera o mencionado autor que a distinção entre estas se presta a conferir maior clareza à exposição ${ }^{98}$.

Neste compasso, haveria extrafiscalidade sempre que a norma tributária refletisse a "efetivação concreta de desidérios constitucionais, de realização dos direitos do cidadão". Por seu turno, a fiscalidade seria identificada quando o escopo da norma fosse o de obtenção de receitas para a subsistência do Estado ${ }^{99}$.

Sendo certo que a norma extrafiscal consubstancia norma tributária dotada, ainda que de forma menos acentuada, do seu aspecto fiscal, não há dúvidas quanto à submissão desta aos ditames norteadores da imposição fiscal. A esse respeito, posicionou-se Paulo de Barros Carvalho ${ }^{100}$ :

Constituindo a extrafiscalidade no emprego de fórmulas jurídicotributárias para obtenção de metas que prevalecem sobre os fins simplesmente arrecadatórios de recursos monetários, o regime que há de dirigir tal atividade não poderia deixar de ser aquele próprio das exações tributárias.

De outra parte, considerando que as normas extrafiscais visam à concretização dos mais diversos objetivos de âmbito econômico prescritos pela Carta Política, resta claro que estas devem estar adstritas aos princípios e regras que norteiam a ordem econômica.

Nesta altura, é possível constatar que, no âmbito da extrafiscalidade, encontram-se normas tributárias que se sujeitam ao regime tributário e aos princípios que regem a ordem econômica, bem como possuem como objetivo primordial a concretização dos mais variados objetivos constitucionais e como fim secundário a arrecadação de recursos para abastecimento do erário.

Fincadas tais considerações acerca da extrafiscalidade como gênero, cumpre pontuar que, para fins do estudo ora empreendido, interessa a extrafiscalidade no sentido estrito, que abrange tão somente as normas tributárias indutoras.

\footnotetext{
${ }^{98}$ GOUVÊA, Marcus de Freitas. Op. cit., p. 47.

${ }^{99}$ Id., loc. cit.

${ }^{100}$ CARVALHO, Paulo de Barros. Op. cit., p. 159.
} 
Isto porque os incentivos fiscais ambientais, objeto do trabalho em tela, encontramse no âmbito da extrafiscalidade não por figurarem como meros alívios tributários (a exemplo de tratamento diferenciado ao desempregado), mas em virtude de estarem voltados ao estímulo ou ao desestímulo de condutas que buscam a efetivação da defesa do meio ambiente, que consubstancia princípio da ordem econômica e da ordem social tutelado pela Carta Política em vigor.

Com efeito, em obra dedicada ao tema das normas tributárias indutoras, Luís Eduardo Schoueri ${ }^{101}$ salientou que o Estado contemplado pela Constituição Federal não é neutro, tendo sido ressaltada no bojo do seu texto a necessidade de viabilização do desenvolvimento econômico nacional afinado com o desenvolvimento humano.

Nessa perspectiva, para o referido jurista, as normas tributárias também não podem ser neutras, devendo ser adotadas finanças funcionais, que se propõem a intervir nos campos social e econômico, com objetivo de redistribuição e equilíbrio, dentre outros.

Pontifica Luís Eduardo Schoueri ${ }^{102}$ que as normas tributárias indutoras consubstanciam forma de intervenção sobre o domínio econômico e também social, sendo identificadas por meio da sua função indutiva, nos seguintes termos: "por normas tributárias indutoras se entende um aspecto das normas tributárias, identificado a partir de uma de suas funções: a indutora". Na sequência, ao abordar seu aspecto normativo, o mencionado autor assim arremata:

[...] por meio das normas tributárias indutoras, o legislador vincula a determinado comportamento um consequente, que consiste em vantagem (estímulo) ou agravamento de natureza tributária. A norma tributária indutora representa um desdobramento da norma tributária primária, na qual se faz presente a indução (ordem para que o sujeito passivo adote certo comportamento).

Nota-se, pois, que as normas tributárias indutoras consubstanciam forma de intervenção do Estado sobre o domínio econômico e também social, identificáveis em virtude da sua função indutiva.

Para que o efeito indutor ocorra, é indispensável que a hipótese de incidência da norma tributária esteja vinculada a uma conduta do contribuinte, conduta esta que pode vir a ser estimulada ou desestimulada pelo tratamento tributário estabelecido. Portanto, o

\footnotetext{
${ }^{101}$ SCHOUERI, Luís Eduardo. Normas tributárias indutoras e intervenção econômica, cit., p. 32.

${ }^{102}$ Id. Ibid., p. 40.
} 
efeito indutor somente é gerado quando há possibilidade de influência de comportamentos (inibição ou estímulos) do destinatário da norma.

Cumpre asseverar, com base nas lições de Luís Eduardo Schoueri ${ }^{103}$, que as normas tributárias indutoras, apesar de inseridas no ordenamento jurídico, por meio de tributos, que lhes servem de veículos, são "instrumentos de que se vale o legislador para conduzir, por indução, o comportamento dos contribuintes, gerando estímulos positivos ou negativos, conforme o contribuinte incorra, ou não, na hipótese prevista em lei”.

Nesta senda, enfatiza-se que as normas indutoras lastreiam-se em regras de mercado e visam a conciliar a intervenção estatal e a liberdade de iniciativa. Assim sendo, é "possível que se beneficiem atividades mais produtivas, sem que se caracterize um privilégio, mas um prêmio, dado o interesse da coletividade na eficiência econômica"104.

Ressalte-se, todavia, que no caso de tributos sobre o consumo, em que se busca o desincentivo à sua aquisição, deve ser verificada a elasticidade da oferta e da demanda, sob pena de a norma tributária apenas implicar o aumento de custo desacompanhado do desvio de conduta, o que não deve ser concebido ${ }^{105}$.

Nesta altura, é possível concluir que os incentivos fiscais ambientais decorrem de intervenção por indução do Estado sobre o domínio econômico. Isto porque serão oferecidas vantagens extras aos contribuintes que vierem a adotar a conduta estipulada pela norma. Tais vantagens não seriam alcançáveis se o mercado estivesse se desenvolvendo livremente.

Com efeito, a norma indutora que veicula um incentivo fiscal consubstancia um convite à adoção de determinado comportamento desejado. A atratividade do convite está atrelada ao tratamento tributário diferenciado conferido àqueles que o aceitam.

Portanto, a intervenção por indução efetivada por meio de incentivo fiscal deverá culminar numa mudança de comportamento do contribuinte, que assim não se moveria caso não the fosse concedido o tratamento tributário abrandado contemplado pela norma tributária.

\footnotetext{
${ }^{103}$ SCHOUERI, Luís Eduardo. Normas tributárias indutoras e intervenção econômica, cit., p. 351.

${ }^{104}$ Id. Ibid., p. 49.

${ }^{105}$ Id., loc. cit.
} 
Destarte, a concessão de incentivos fiscais de viés ambiental (isenção, redução de base de cálculo ou alíquota, concessão de crédito presumido, diferimento etc.) presta-se à orientação de comportamentos que irão concretizar referido fim constitucional.

Neste compasso, o Legislador, ao verificar, por exemplo, que os resíduos sólidos não estão tendo a devida destinação, de sorte a prejudicar as condições do meio ambiente, poderá veicular incentivo fiscal para o fomento do descarte adequado de tais resíduos. Será utilizado, assim, instrumental tributário, sendo identificada uma hipótese e uma consequência.

Por outro lado, as atividades degradantes ao meio ambiente podem ter sua carga tributária majorada com o intuito de inibir a sua expansão.

Do quanto até aqui exposto, resta claro que as normas tributárias indutoras, que se encontram no âmbito da extrafiscalidade, poderão estimular comportamentos que favoreçam a preservação do meio ambiente, bem como inibir condutas que vão de encontro a esse fim, pois, como já firmado, a proteção ambiental constitui objetivo assumido pelo Estado brasileiro.

Com efeito, demonstrar-se-á, com mais vagar, no item seguinte, como a tributação pode servir de instrumento de proteção ambiental.

\subsection{O tributo como instrumento de defesa do meio ambiente}

A Organização de Cooperação e de Desenvolvimento Econômico - OCDE ${ }^{106}$ sustenta que "os tributos ambientais (écotaxes), desde que adequadamente concebidos e postos em prática, podem ter uma real eficácia em matéria de proteção do meio

\footnotetext{
106 A OCDE (Organização para Cooperação e Desenvolvimento Econômico) é uma Organização Internacional formada por diversos países que tem como objetivos coordenar políticas econômicas e sociais, apoiar o crescimento econômico sustentável, aumentar o emprego e a qualidade de vida dos cidadãos, manter a estabilidade financeira, preservar o meio ambiente em paralelo com uma economia sustentável, dentre outros.

Trata-se de órgão internacional e intergovernamental que reúne os países mais industrializados e também alguns emergentes, como México, Chile e Turquia. Por meio da OCDE, os representantes se reúnem para trocar informações e alinhar políticas com o objetivo de potencializar seu crescimento econômico e colaborar com o desenvolvimento de todos os demais países-membros (OCDE. Taxation, innovation and the environment. Disponível em: <www.oecd.org/publishing/corrigenda>. Acesso em: 15 ago. 2012).
} 
ambiente ${ }^{107 ،,}$, razão pela qual a questão ambiental, desde 1990, vem sendo inserida nos sistemas fiscais de vários países integrantes da aludida organização.

Em 2010, a OCDE divulgou relatório, intitulado "Tributação, Inovação e o Meio Ambiente" ${ }^{\prime 108}$, no bojo do qual foi realizada análise acerca da relação entre a inovação e a adoção de novas tecnologias para atingir metas ambientais a custos mais baixos, contextualizando o meio ambiente, os impostos e o modo como estes estão sendo utilizados como um dos mecanismos mais eficazes de proteção do meio ambiente.

Embora o estudo não tenha comprovado de forma inequívoca que a criação de tributo ambiental sempre resultará em inovação e em adoção de novas tecnologias e processos, em vista de certos aspectos ${ }^{109}$, logrou evidenciar que os tributos incidentes sobre a poluição fazem com que os poluidores busquem alternativas mais limpas, na tentativa de reduzir custos diretos.

Foi pontuada a preocupação que se tem de tais políticas serem mais rigorosas em determinadas jurisdições do que em outras, prejudicando a competitividade das primeiras. Contudo, ponderou-se que uma cooperação internacional e uma coordenação na criação dos impostos resolveriam tal questão e, ainda, serviriam para fomentar o intercâmbio e a difusão das inovações entre Estados que adotassem impostos incidentes sobre um mesmo produto, por exemplo.

Avaliou-se que os tributos adequadamente desenhados representam bem os danos ao meio ambiente e superam grande parte do problema da externalidade ambiental. Foi identificado, ainda, o uso de figuras desonerativas que reduzem a tributação incidente sobre bens ambientalmente amigáveis.

Nesta perspectiva, três categorias de medidas tributárias, tidas como passíveis de ser utilizadas para atingir propósitos ambientais e de inovação, foram citadas pelas

\footnotetext{
${ }^{107}$ OCDE. Écotaxes et Reforme Fiscale Verte. Reimpressão. Paris: OCDE, 1997. p. 12.

108 OCDE. Taxation, innovation and the environment, cit.

${ }^{109}$ Nesse sentido, levou-se em consideração que: a) trata-se de um assunto relativamente novo, acarretando um espaço limitado para aplicação e análise; b) a localização e identificação de potenciais inovações decorrentes dos incentivos criados pela tributação é tarefa difícil, considerando as atividades que já são desenvolvidas; c) impostos de meio ambiente podem não ser bem recebidos, pois podem diminuir as atividades e decisões de investimentos; e d) há outros fatores que afetam as atividades de inovação das empresas. In OCDE. Taxation, innovation and the environment, cit.
} 
Reuniões conjuntas dos especialistas tributários e ambientais da OCDE (Joint Meetiings of Tax and Environmental Experts - JMTEE) ${ }^{110}$ :

1. Desencorajamento do ambientalmente "ruim" mediante a inclusão de um custo nas atividades prejudiciais ao meio ambiente, por intermédio da tributação da poluição em si ou sobre bens relacionados à emissão de poluentes (combustíveis, por exemplo) - the stick approach (a abordagem do bastão).

2. Indução do ambientalmente "bom" mediante a redução dos seus custos, o que é conhecido como the carrot of environmental policy (a cenoura da política ambiental). Exemplos de medidas nessa categoria incluem reduções específicas da alíquota de tributos incidentes sobre o valor agregado, relativos a certos produtos e atividades que são menos prejudiciais ao meio ambiente e depreciação acelerada para investimentos em capital relacionados ao meio ambiente.

3. Indução da inovação por meio do fornecimento de incentivos positivos para efetivação de ações a fim de aumentar a inovação (de forma ampla ou direcionada ao meio ambiente), por intermédio da implementação de medidas para redução dos custos de inovação, como créditos fiscais de $\mathrm{P} \& \mathrm{D}$, depreciação acelerada para capital de inovação e aumento das deduções para os custos de mão de obra de $\mathrm{P} \& \mathrm{D}$ ou redução de tributos sobre a mão de obra de P\&D. Do mesmo modo, medidas para aumentar o retorno da inovação, como alíquotas reduzidas de Imposto de Renda da PJ sobre certos tipos de rendimento. Nesse caso, o governo usa o sistema tributário para encorajar a inovação adicional com medidas como créditos fiscais de P\&D e redução das alíquotas de IRPJ sobre os rendimentos da inovação.

Neste compasso, em maio de 2011 foi lançada, na Reunião do Conselho Ministerial da OECD, a "Estratégia de Crescimento Verde" (Green Growth Strategy) ${ }^{111}$, que constituiu parte das contribuições da OECD para a Conferência Rio +20 em junho de 2012.

Tal Estratégia responde ao mandado outorgado à OECD para desenvolver uma Estratégia de Crescimento Verde que levasse em consideração aspectos econômicos, ambientais, sociais, tecnológicos e de desenvolvimento. Ministros de 34 países deram essa atribuição à OECD por intermédio da assinatura da Declaração de Crescimento Verde (Green Growth Declaration), sendo então anunciado que eles iriam "aumentar seus esforços para obter estratégias de crescimento verde como parte da sua reação à crise, reconhecendo que verde e crescimento podem seguir de mãos dadas".

\footnotetext{
110 OCDE. Green growth and sustainable development. Disponível em: $<$ http://www.oecd.org/greengrowth/keydocuments.htm>. Acesso em: 19 set. 2012. ${ }^{111}$ Id. Ibid.
} 
Nesse contexto, a Estratégia dá as diretrizes para os governos promoverem crescimento econômico e ao mesmo tempo protegerem o meio ambiente, e isso se refere especificamente à tributação como um dos instrumentos de política ambiental.

A Estratégia de Crescimento Verde estipula que dois amplos conjuntos de políticas são elementos essenciais em qualquer estratégia de crescimento verde. Primeiro, uma extensa política de diretrizes que ao mesmo tempo reforça o crescimento econômico e a conservação do capital natural. Isso inclui determinações essenciais de natureza fiscal e regulatória como políticas de tributação e competição, assim como políticas de inovação.

O segundo conjunto de políticas abrange medidas promovendo incentivos para uso de recursos naturais de forma eficiente e o encarecimento da poluição. Isso inclui um misto de instrumentos baseados em preço, como tributos relacionados ao meio ambiente e instrumentos de não mercado, a exemplo de regulamentos e políticas de suporte à tecnologia.

Ao tratar especificamente da tributação, o Relatório "Towards Green Growth""112 (também parte da Estratégia e emitido para dar direcionamentos práticos a fim de que os governos aumentem o crescimento econômico e protejam o meio ambiente) menciona dois tipos de política: 1. Racionalização de medidas de suporte governamental que são potencialmente prejudiciais ao meio ambiente, como gastos tributários destinados a setores produtivos que geram alto impacto ambiental e 2 . Uso de tributos relacionados ao meio ambiente.

Voltando-se para o contexto jurídico brasileiro, observa-se que, considerando que a proteção do meio ambiente constitui objetivo de relevo no texto constitucional e que o Estado se vale dos recursos oriundos da tributação para concretizar os seus mais diversos fins, é possível o manejo da tributação com o intuito de alcançar o fim de proteção ambiental.

Nesta esteira, Marcelo Figueiredo ${ }^{113}$, ao fazer a vinculação entre a tributação e o meio ambiente, parte da premissa de que "a defesa do meio ambiente é um valor constitucional fundamental imbricado com a dignidade da pessoa humana e também com o desenvolvimento econômico e social", para concluir que não é possível considerar o meio

\footnotetext{
112 OCDE. Towards Green Growth. Disponível em: <http://www.oecd.org/greengrowth/48224539.pdf>. Acesso em: 19 set. 2012.

113 FIGUEIREDO, Marcelo. Mesa de Debates C. Tributação, Ecologia e Meio Ambiente. (XIII Congresso Brasileiro de Direito Tributário). Revista de Direito Tributário, São Paulo, n. 78, p. 70, 1999.
} 
ambiente como um valor isolado, uma estrela solitária na constelação constitucional, sendo necessário inseri-lo na política econômico-financeira e tributária do Estado.

Ressalte-se, entretanto, que não há autorização no ordenamento jurídico pátrio para que se institua exação com viés ambiental que se afigure discriminatória, violadora do art. 150, I, que versa sobre a igualdade no âmbito tributário.

Ademais, não há margem para a criação de tributo ambiental que venha a: produzir efeito confiscatório, terminantemente vedado pelo art. 150, IV; vulnerar a capacidade contributiva, de que trata o art. 148; aniquilar o princípio do livre exercício da atividade econômica, protegido pelo art. 170 da Carta Política etc.

Neste cenário, a instituição ou majoração de tributos, ainda que no âmbito da extrafiscalidade, deve ter em conta que o poder de tributar possui amarras postas pela própria Constituição (que contempla normas balizadoras da atuação estatal, incluindo-se a definição minudente da competência impositiva dos respectivos entes tributantes) e que a concretização de um objetivo constitucional, por mais relevante que seja, como é o caso da defesa ambiental, deve harmonizar-se com os demais fins e limitações constitucionais, sendo tal compatibilização de princípios e regras imperativa num Estado Democrático de Direito.

Da mesma forma, não poderá a lei tributária, visando a fomentar comportamentos compatíveis com a preservação do meio ambiente, conceder aos contribuintes isenções, créditos presumidos, subvenções, entre outros, de forma aleatória. É preciso que referido tratamento tributário diferenciado também esteja em conformidade com os outros objetivos constitucionais.

A necessidade de arrecadação do Estado não é, por si só, argumento suficiente para impedir a criação ou extinguir incentivos fiscais que fomentem a prática de atividades menos gravosas ao meio ambiente.

Insta pontuar que o sistema tributário brasileiro não foi formulado incluindo o componente ambiental no seu bojo, daí por que o manejo da extrafiscalidade para proteção ambiental, pela sua importância, deve ser estudado e estruturado pelos operadores do Direito (doutrinadores, legisladores e julgadores) da atualidade.

Vale rememorar que a tributação no país teve sua sistematização propriamente dita em 1966, com a edição da Lei n. ${ }^{\circ}$ 5.172. Tal diploma legal, consagrado como o Código Tributário Nacional - CTN, é responsável por contemplar as normas gerais tributárias e, 
em conjunto com a Constituição Federal, estipula as vigas mestras da tributação no país na atualidade.

O referido Código não fez qualquer alusão à questão ambiental. Nem se esperava que fosse diferente, haja vista que, no contexto em que foi elaborado, afigurava-se extremamente tímida a preocupação com a conservação dos rios e dos solos, e pouco discutida a questão da exploração equilibrada dos recursos naturais e do descarte dos resíduos.

A percepção mais difundida à época era a de que as terras e os recursos a serem explorados eram infindáveis. De tal modo, à medida que os solos se tornavam estéreis, migrava-se para áreas do interior, enquanto, paralelamente, os depósitos de lixo expandiam-se com o desenvolvimento acelerado dos centros urbanos ${ }^{114}$.

Vale ressaltar que, nos países europeus, tal negligência com a questão ambiental também se fazia presente. Deveras, no período do pós-guerra, o foco desses países era a reconstrução e o fortalecimento das estruturas produtivas. Nos anos 60 , o centro das preocupações repousava nos objetivos de livre circulação de fatores de produção (pessoas, capitais, mercadorias e serviços) ${ }^{115}$.

Neste cenário, a proteção do meio ambiente não constava no texto constitucional dos países, havendo apenas referências esparsas nos tratados fundantes da antiga Comunidade Europeia, atual União Europeia ${ }^{116}$.

\footnotetext{
${ }^{114}$ Não se pode deixar de registrar, todavia, que, ainda na década de 60, a Lei n. ${ }^{\circ}$ 4.771/1965 introduziu os conceitos de Área de Preservação Permanente (APP) e de Reserva Legal (RL). Seu escopo era preservar as regiões que possuíam funções ecológicas relevantes e também garantir o bem-estar das comunidades, como a manutenção do microclima. Foram classificadas como Áreas de Preservação Ambiental as matas ciliares (às margens de rios), os reservatórios de água, as nascentes, as bordas da chapada, as encostas e topos de morros.

Por sua vez, as Reservas Legais são áreas de vegetação nativas que devem ser conservadas em cada propriedade, podendo ser exploradas, desde que de forma racional, sem prejuízo à sua conservação.

Tal norma, entretanto, foi inserida num contexto em que imperavam ostensivas políticas públicas voltadas à ocupação de regiões de fronteira agrícola, como Pará, Mato Grosso e Rondônia. Desse modo, a proteção ambiental ainda se afigurava incipiente e titubeante.

115 SERRANO ANTÓN, Fernando. La tributación medioambiental en la Unión Europea. In: BECKER, Fernando; CAZORLA, Lui Maria; MARTÍNEZ-SIMANCAS, Julián (Dir.). Tratado de tributación medioambiental. Pamplona: Aranzandi, 2008. v. 2, p. 818-819.

116 Acerca da União Europeia, Cristóbal J. Borrero Moro, em artigo intitulado Límites del Derecho comunitario a los tributos ambientales, assim preleciona: "La Comunidad Europea es una organización supranacional, articulada sobre um cuerpo normativo: el ordenamiento jurídico comunitario. Esta organización jurídica tiene su fundamento em la atribución de competências constitucionales a las Comunidades Europeas por parte de los Estados miembros - art. 93 CE-. La adhesión de España a las Comunidades Europeas tiene como efecto inmediato la incorporación del Derecho comunitario al ordenamiento jurídico español. Aquél 'constituye um orden jurídico propio integrado em el sistema jurídico de los Estados miembros' (Sentencia del Tribunal de Justicia de las Comunidades Europeas - enadelante
} 
Todavia, o crescente desenvolvimento industrial, fruto das exitosas políticas de reconstrução, começou a gerar, na década de 70, efeito negativo sobre o meio ambiente.

Como consequência, foram adotadas algumas medidas para corrigir tal situação. Entre elas, houve a introdução expressa, em todas as constituições cunhadas naquela época, de dispositivos que estabeleciam a proteção do meio ambiente. Com efeito, as referidas disposições constitucionais conformaram o fundamento para suas respectivas políticas estatais em matéria tributária ${ }^{117}$.

Entretanto, foi em 1972, com a Conferência Mundial de Estocolmo, que as questões ambientais ganharam a atenção dos países, sendo, a partir de então, e de forma mais sistemática, criadas normas com viés preservacionista nos ordenamentos jurídicos.

No tocante ao ordenamento jurídico nacional, verifica-se que a Constituição Federal de 1988, inspirada nas discussões travadas na aludida Conferência Mundial de Estocolmo, contemplou o tema da proteção ambiental em diversos dispositivos. E, ato contínuo, sob a influência do Protocolo de Quioto, a Carta Política foi emendada, passando a prever expressamente o tratamento econômico diferenciado em relação a bens e serviços com base no critério ambiental.

Nota-se, portanto, que a aproximação entre tributação e meio ambiente adquire força a partir das disposições constitucionais, fruto do amadurecimento e da evolução da conscientização mundial sobre o tema.

Nesta perspectiva, e considerando a abertura da Constituição brasileira, conceitos como o de seletividade e de essencialidade, vinculados à tributação do consumo e tradicionalmente relacionados aos bens de primeira necessidade, adquirem novos contornos, passando a ser concebidos como "seletividade ambiental" e "essencialidade ambiental". Daí, a aquisição de um bem que, embora não seja essencial para a sobrevivência do indivíduo, seja capaz de reduzir o consumo energético, passa a ter

\footnotetext{
STJCE - Costa/ENEL 6/64). Ordenamiento jurídico, que como ha reconocido el Tribunal de Justicia de las Comunidades Europeas (em adelante TJCE), tiene primacía y efecto directo sobre el ordenamiento interno. De hecho, los Estados miembros com la atribución de competencias a las Comunidades Europeas "han limitado, aunque em ámbitos restringidos, sus derechos soberanos y han creado a si um cuerpo de derecho aplicable a sus súbditos y a ellos mismos (STJCE Costa/ENEL, de 15 de julio de 1964). Esta articulación jurídica repercute directamente sobre la configuración jurídica del poder tributario de los Estados miembros, que debe integrar em su seno el ordenamiento jurídico comunitario, de modo tal que el sistema resultante ha de ser coherente y respetuoso com el conjunto de normas y principios que integran esse derecho comunitário" (BORRERO MORO, Cristóbal José. Límites del derecho comunitario a los tributos ambientales. Noticias de la Unión Europea, Valencia, ano 17, n. 193, p. 20, feb. 2001).

${ }^{117}$ SERRANO ANTÓN, Fernando. Op. cit., v. 2, p. 819.
} 
fundamento para uma tributação reduzida, por se afigurar crucial na manutenção dos recursos naturais.

Por seu turno, passam a ser de interesse da tributação os efeitos para o meio ambiente produzidos por determinado bem ou serviço, servindo, pois, o componente ambiental (impactos ao meio ambiente) como termômetro à imposição tributária.

Nesta diretriz, e tendo em vista a paulatina inclusão do critério ambiental na elaboração e aplicação da norma tributária no Direito brasileiro, abordar-se-á esse fenômeno no Direito nacional e comparado, por meio da indicação de exemplos concretos de tributos voltados à proteção do meio ambiente.

\subsubsection{A experiência brasileira e estrangeira}

\subsubsection{Tributos ambientais no Brasil}

Ainda não há, no Brasil, sistematização que permita defender a existência de uma tributação ambiental propriamente dita, de viés impositivo. Em verdade, são identificados tributos ambientais de forma esparsa e pontual.

Nesse sentido, verificam-se, por exemplo, taxas em função do poder de polícia ambiental pulverizadas pelo país e também de âmbito nacional.

Ressalte-se a Taxa de Controle e Fiscalização Ambiental- TCFA, instituída pela Lei n. ${ }^{\circ} 10.165 / 2000$, de competência federal. O fato gerador da taxa em foco é o exercício regular do poder de polícia conferido ao IBAMA para fiscalizar atividades poluidoras, que utilizam recursos ambientais (art. $\left.1 .^{\circ}\right)$.

Encontram-se abrangidas pela norma em questão as atividades controladas pelo IBAMA (indicadas no seu anexo VIII). São elas: extração e tratamento de minerais, indústria de produtos minerais não metálicos, indústria metalúrgica, indústria mecânica, indústria de material elétrico, eletrônico e de comunicações, indústria de madeira, indústria de papel e celulose, indústria de borracha, indústria de couros e peles, indústria têxtil, de vestuário, calçados e artefatos de tecidos, indústria química, entre outras. 
A sua base de cálculo combina o potencial de poluição da atividade (pequeno, alto e médio) com o porte do sujeito passivo (classificação, conforme a receita bruta, em microempresa, empresa de pequeno porte, empresa de médio porte, empresa de grande porte). Assim, por exemplo, uma empresa de médio porte, cuja atividade é classificada pela norma em destaque como de baixo potencial ofensivo, terá de recolher taxa em montante menor do que aquela cobrada de empresa de grande porte e de médio potencial ofensivo.

Vale ressaltar que a imposição em tela é extremamente criticada, sob o argumento de que falta contraprestação a embasar a sua cobrança (desconexão com o seu custo do serviço) e de que tal imposição está voltada exclusivamente ao incremento da receita da aludida autarquia federal.

Ademais, uma vez que sua base de cálculo veicula uma presunção absoluta, acaba por punir aqueles contribuintes que reduzem a poluição, por intermédio de investimentos em projetos de inovação tecnológica (energia renovável e para sequestro de gases de efeito estufa), porquanto todo o esforço para que seus processos produtivos tenham suas emissões neutralizadas é desconsiderado pela citada exação.

Deveras, nos termos em que se encontra formulada, a TFCA não estimula a adoção de comportamentos direcionados a mudanças no aparato produtivo e na exploração de recursos ambientais, podendo, ao contrário, seu adimplemento ser concebido pelos sujeitos passivos como verdadeira autorização para poluir ${ }^{118}$.

Por oportuno, mencione-se a Taxa de Preservação Ambiental - TPA, instituída pela Lei n. ${ }^{o}$ 10.403/1989, para o Distrito Estadual de Fernando de Noronha, Estado de Pernambuco, que é calculada de acordo com o período de permanência no referido território.

Nos termos do art. 88 do citado diploma legal, a receita proveniente da TPA deverá ser aplicada "nas despesas realizadas pela Administração Geral para manutenção das condições gerais de acesso e preservação dos locais turísticos e dos ecossistemas naturais, existentes no Arquipélago de Fernando de Noronha, e para a execução geral de obras e

\footnotetext{
${ }^{118}$ Acerca das críticas à taxa em foco, consultar, por todos, OLIVEIRA, José Marcos Domingues de. Direito tributário e meio ambiente. 3. ed. Rio de Janeiro: Forense, 2007.
} 
benfeitorias em benefício da população local e dos visitantes, inclusive para remuneração de pessoal com exercício de função na execução das mencionadas atividades" ${ }^{\prime 19}$.

Constata-se, também, a criação de taxas florestais por diversos Estados brasileiros $^{120}$, as quais, em geral, estão relacionadas ao exercício do Poder de Polícia realizado pelas autoridades ambientais, em relação a pessoas jurídicas que exercem atividades de exploração e consumo de produtos de origem florestal.

O Estado de Minas Gerais, por meio da Lei n. ${ }^{\text { }}$ 4.747/1968, estipulou que a taxa florestal estadual serviria "à manutenção dos serviços de fiscalização e polícia florestal, a cargo do Instituto Estadual de Florestas" (art. 58), sendo exigida à alíquota de 3\% sobre o valor dos produtos ou subprodutos florestais e sobre o valor do desmatamento calculado segundo pauta publicada semestralmente pelo Instituto Estadual de Florestas.

Para fins de incidência da referida taxa, são produtos de origem florestal a lenha, a madeira apropriada à indústria, as raízes ou tubérculos, as cascas, folhas, frutos, fibras, resinas, seivas, sementes e, em geral, tudo o que for destacado de espécies florestais e que se preste diretamente ao uso do homem. Por sua vez, constituem subprodutos florestais o carvão vegetal e os resultantes da transformação de algum produto vegetal por interferência do homem ou pela ação prolongada dos agentes naturais.

A par das taxas, insta pontuar exemplos identificados em sede de tributo muito propício à veiculação de conteúdo ambiental, qual seja a contribuição de intervenção no domínio econômico - CIDE, de competência exclusiva da União (art. 149 da CF/1988), que possui caráter extrafiscal e arrecadação vinculada ${ }^{121}$.

Nesta perspectiva, a Lei n. ${ }^{\circ}$ 9.433/1997, que dispõe sobre política de recursos hídricos, previu uma CIDE para concessão de direitos de uso desses recursos.

\footnotetext{
${ }^{119}$ De acordo com o Decreto Distrital n. ${ }^{\circ}$ 18/2004, esta taxa foi criada em face da "necessidade de garantir a utilização, efetiva ou potencial, por parte das pessoas visitantes, da infraestrutura física implantada no Distrito Estadual e o acesso e fruição ao seu patrimônio natural e histórico".

${ }^{120}$ Saliente-se, a título exemplificativo, a Lei n. ${ }^{\circ}$ 5.440/1988 do Estado do Pará, que criou o Instituto Estadual de Florestas do Pará (IEF), órgão responsável pela realização da política florestal do Estado, e instituiu a Taxa Florestal incidente sobre as "atividades fiscalizadoras, administrativas e policiais de competência do Estado no setor florestal e aquelas oriundas da delegação federal para execução, através do Instituto Estadual de Florestas, das atividades decorrentes do Código Florestal, da Lei de Proteção à Fauna e de outros dispositivos legais pertinentes" (art. $4 .^{\circ}$ ). Na mesma senda, o Rio de Janeiro introduziu taxa de tal natureza, veiculada pela Lei ${ }^{\circ} 3.187 / 1999$, cuja arrecadação ocorre em virtude "do exercício do poder de polícia, que se manifesta através da fiscalização florestal e das atividades administrativas a ela vinculadas, exercidas pelo Estado do Rio de Janeiro" (art. 1. ${ }^{\circ}$ ).

121 Sobre a contribuição em tela, ver: HORVATH, Estevão. Contribuição de intervenção no domínio econômico. São Paulo: Dialética, 2009.
} 
Há, ainda, a Lei n. ${ }^{0}$ 10.336/2001, que introduziu a CIDE sobre a importação e a comercialização de petróleo e seus derivados, gás natural e seus derivados, e álcool etílico combustível (art. $1^{\circ}, \S 1^{\circ}$, III). A esse respeito, registre-se que o inciso II do $\S 4^{\circ}$ do art. 177 da Lei Maior (introduzido pela EC 33/2001), determina que os recursos arrecadados por meio da CIDE serão destinados ao financiamento de projetos ambientais relacionados à indústria do petróleo e do gás.

\subsubsection{Tributos ambientais no Direito comparado}

$\mathrm{Na}$ União Europeia, durante os anos 70 e 80, as diretivas dirigiam-se, primordialmente, à limitação das emissões poluentes. Em seguida, a estratégia de proteção ambiental passou a abarcar também o consumo de recursos naturais ${ }^{122}$.

Assim foi que, nos últimos vinte anos, a União Europeia ampliou o número de programas comunitários dedicados ao meio ambiente. Com efeito, o denominado "Quinto Programa de Ação Ambiental" já trouxe em seu bojo estratégia muito mais direta no que tange à proteção do meio ambiente e à preservação dos recursos naturais ${ }^{123}$.

Muitos fatores foram decisivos para que tal programa fosse menos programático do que os anteriores. Dentre eles, o fato de que o meio ambiente, apesar das normas ambientais precedentes, continuava a ser degradado, diante do que aumentava a responsabilidade da União Europeia perante os cidadãos em tal seara.

Contudo, foi o "Sexto Programa de Ação Ambiental", designado como "meio ambiente 2010: o futuro está em nossas mãos", que trouxe contribuições de maior relevo para este trabalho, porquanto, por intermédio do referido programa, foram delineadas as diretrizes cruciais para a política ambiental para 2001-2010, tendo como principal objetivo a construção de um meio ambiente sadio e uma melhor qualidade de vida para os cidadãos, propiciando, assim, que o desenvolvimento atingido fosse sustentável ${ }^{124}$.

E, o mais importante, o aludido programa contemplou os tributos ecológicos, sendo definido um conjunto de parâmetros para delinear um tributo ambiental apto a alcançar o respeito ao meio ambiente na maior medida possível.

\footnotetext{
${ }^{122}$ SERRANO ANTÓN, Fernando. Op. cit., v. 2, p. 819.

${ }^{123}$ Id. Ibid., p. 822.

${ }^{124}$ Id. Ibid., p. 823 .
} 
Nesse sentido, estipulou-se a necessidade de: i) análise da experiência em tributos ecológicos já instituídos para avaliação da estrutura básica da imposição, tais como o fato imponível, o método para valorar a base de cálculo e o custo administrativo do tributo ecológico; ii) estudo do grau de integração e aceitação dos tributos ambientais nos diferentes sistemas fiscais (progressividade, medidas de compensação e mitigação); iii) destinos dos ingressos (aumentar os gastos com iniciativas que aumentam o crescimento econômico e número de empregos, redução de outros impostos etc.); iv) elaboração de modelo teórico de políticas fiscais ambientais (reforma fiscal ecológica) que amplie o sistema existente ${ }^{125}$.

Herrera Molina, visando a facilitar a compreensão e a sistematização do tema, propõe a classificação dos tributos ambientais em sete categorias: contaminação atmosférica, automóveis, insumos agrícolas, água, resíduos, transporte aéreo e produtos específicos $^{126}$.

Nesta altura, uma vez tecidas as referidas considerações gerais acerca da preocupação com o meio ambiente e o surgimento de diretrizes para a criação de tributos ambientais, passa-se a analisar a instituição concreta de tributos incidentes sobre condutas contrárias ao meio ambiente e ao desenvolvimento sustentável, nos mais diversos países.

Assim, por exemplo, a Áustria ${ }^{127}$ cobra impostos sobre veículos, seu seguro e o combustível por eles utilizados, na tentativa de influenciar os cidadãos a evitar esse tipo de meio de transporte, que contribui para a poluição do ar.

O imposto incidente sobre os veículos automotores nacionais ou importados possui valor baseado nas cilindradas das motocicletas e nos cavalos dos motores dos veículos.

No caso de veículos de passeio com peso bruto inferior a 3,5 toneladas, é cobrado um imposto sobre o seguro que deve ser obrigatoriamente realizado pelo proprietário.

Com base nessa mesma intenção, foi instituído imposto sobre o consumo de combustíveis, que varia de acordo com o tipo, a quantidade de combustível consumido e a quantidade de determinados componentes presentes, como, por exemplo, o enxofre.

Ademais, veículos menores que viajam em estradas da Áustria ${ }^{128}$ devem pagar também um pedágio, antecipadamente, por meio da compra de adesivos que devem ser

\footnotetext{
${ }^{125}$ SERRANO ANTÓN, Fernando. Op. cit., v. 2, p. 824.

${ }^{126}$ HERRERA MOLINA, P. Op. cit., p. 78.

127 Maiores informações em AUSTRALIAN GOVERNMENT. Australian taxation office. Disponível em: $<$ http://www.ato.gov.au>. Acesso em: 30 jul. 2012.

${ }^{128}$ Id. Ibid.
} 
colocados no carro. O custo anual para cada adesivo varia, a depender do tamanho do veículo. No caso de caminhões, é cobrada uma taxa de pedágio por quilometragem.

Além das exações já citadas, a Áustria ${ }^{129}$ exige impostos sobre áreas contaminadas, atividades de pesca e caça, desmatamento e conservação das paisagens e da natureza, tudo em prol do meio ambiente.

Por seu turno, a Dinamarca ${ }^{130}$ utiliza tributos para desestimular condutas contrárias ao meio ambiente. Esses tributos incidem sobre águas residuais, embalagens, louças descartáveis, produtos em PVC, enlatados, sobre o dióxido de carbono e certos produtos energéticos, pesticidas, nitrogênio, pneus de borracha, resíduos perigosos, solventes à base de cloro, baterias à base de níquel/cádmio, enxofre, fosfato em ração animal, dentre outros.

Da sua parte, a Inglaterra ${ }^{131}$ possui considerável gama de tributos tendentes a onerar condutas que impactam negativamente o meio ambiente.

Em 2001, foi instituído imposto sobre a mudança climática ("CCL” - Climate Change Levy - United Kingdom), para incentivar as empresas a usarem menos energia e/ou encorajá-las a utilizar energia proveniente de fontes renováveis. Esse imposto faz parte de uma estratégia do governo do Reino Unido quanto às mudanças climáticas, na tentativa de contribuir com as metas de redução de emissão dos gases do efeito estufa. Ele é cobrado dos fornecedores de energia e incide sobre a energia (eletricidade, gás, combustível sólido e gás liquefeito) utilizada por consumidores não domésticos. O "CCL" é aplicado a uma taxa específica por unidade de energia nominal.

Ademais, em fevereiro de 2003, o prefeito de Londres introduziu o Regime da Taxa de Congestionamento de Londres ("C-Charge"), para reduzir as emissões de dióxido de carbono. A taxa diária é cobrada sobre veículos que utilizam as estradas na zona C-Charge no centro de Londres entre sete da manhã e seis da tarde, de segunda a sexta-feira (exceto feriados). Em outubro de 2008, os carros menores, com emissões abaixo de $120 \mathrm{~g}$ de dióxido de carbono por quilômetro, ficaram isentos do C-Charge. Por outro lado, a CCharge foi aumentada para veículos que emitem mais de $225 \mathrm{~g}$ de dióxido de carbono por quilômetro.

\footnotetext{
${ }^{129}$ AUSTRALIAN GOVERNMENT. Australian taxation office. Disponível em: <http://www.ato.gov.au> . Acesso em: 30 jul. 2012.

${ }^{130}$ STATSMINISTERIET. Disponível em: <http://www.stm.dk/>. Acesso em: 15 out. 2012.

${ }^{131}$ HM REVENUE \& CUSTOMS. Disponível em: <http://www.hmrc.gov.uk/>. Acesso em: 15 out. 2012.
} 
Ainda no âmbito da tributação ambiental, consta, na Inglaterra ${ }^{132}$, o imposto sobre o consumo de combustíveis, incidente sobre as empresas produtoras/importadores e sobre os compradores de óleos, hidrocarbonetos e outros produtos combustíveis, cujo valor é de $£$ 0,5795 por litro. Um imposto sobre o valor agregado (IVA) também é cobrado sobre o preço do combustível e no próprio imposto sobre combustíveis. Existe, ainda, um imposto especial adicional sobre a emissão de gás carbônico dos veículos.

Já o Imposto sobre aterros ("LFT") incide sobre o lixo descartado em aterro licenciado. $\mathrm{O}$ referido imposto foi concebido para incentivar as empresas a produzirem menos lixo, reduzindo, assim, a quantidade de resíduos enviados para aterros sanitários. A cobrança depende do tipo de resíduo depositado: a menor taxa é de $£ 2,50$ por tonelada (rochas e solos naturais, cerâmica e concreto, minerais não utilizados, restos de carvão produzidos em fornalhas, cinzas etc.), e a taxa normal é de $£ 64$ por tonelada (de todos os outros resíduos tributáveis). O Departamento para o Ambiente, Alimentos e Assuntos Rurais anunciou que a taxa normal continuará a aumentar cerca de $£ 8$ a cada ano, pelo menos até 2014-2015, podendo chegar a $£ 80$ por tonelada.

Não poderia se deixar de tratar, por fim, da Cobrança sobre Agregados (“AGL”), imposto sobre a exploração comercial de vários agregados (incluindo cascalho, areia e rocha) que são extraídos do solo no Reino Unido ${ }^{133}$ (incluindo o fundo do mar em águas territoriais do Reino Unido). O objetivo da "AGL" é reduzir a demanda por agregados e, assim, reduzir o dano ambiental causado por essas atividades. A taxa básica da AGL está atualmente fixada em $£ 2$ por tonelada.

Também, no Canadá ${ }^{134}$, existem intervenções estatais previstas pelas suas províncias, relacionadas às emissões de gases do efeito estufa. A província de Quebec prevê um Imposto do Carbono (carbono tax), cobrado sobre uma determinada quantidade de emissão desses gases. A província de British Columbia, por sua vez, possui mecanismos semelhantes para dirimir a emissão desses gases.

Outras províncias do Canadá, da mesma forma, instituíram programas de manejo eletrônico que cobram uma taxa de manuseio ambiental ("EHF") sobre alguns novos produtos elétricos e eletrônicos. As "EHFs" são normalmente pagas pela pessoa com uma conexão comercial mais estreita com o fornecimento dos produtos e que seja residente na

\footnotetext{
${ }^{132}$ HM REVENUE \& CUSTOMS. Disponível em: <http://www.hmrc.gov.uk/>. Acesso em: 15 out. 2012. ${ }^{133}$ Id. Ibid.

${ }^{134}$ CANADA REVENUE AGENCY. Disponível em: <http://www.cra-arc.gc.ca/>. Acesso em: 15 jul. 2012.
} 
província ("Fornecedor"). O objetivo dos programas é cobrir o custo de reciclagem e eliminação de resíduos eletrônicos. Semelhantes programas de manejo provinciais têm sido criados para ajudar a pagar o custo da reciclagem e reutilização de embalagens de produtos, materiais impressos e resíduos perigosos.

Explorada, pois, a vertente da tributação ambiental que se destina à oneração daquele que polui, ou seja, a vertente da imposição fiscal, passa-se a abordar o lado inverso da moeda, relativo à desoneração fiscal.

Com efeito, adentrar-se-á na análise dos incentivos fiscais em geral, para, em seguida, investigar a aplicação do aludido instituto com o viés ambiental. 


\section{INCENTIVOS FISCAIS}

\subsection{Acepção e alcance do instituto}

Abordou-se linhas acima o caráter extrafiscal do tributo e a sua utilização como instrumento concretizador de políticas econômicas e sociais, hipótese em que as normas tributárias se voltam para a função regulatória.

Com efeito, é no contexto da extrafiscalidade que se situa o incentivo fiscal ${ }^{135}$, cuja origem consiste numa intervenção estatal destinada à promoção de fins juridicamente tutelados, a exemplo do desenvolvimento econômico e social. Por meio de tal intervenção, é criada uma norma que conferirá tratamento tributário mais brando ao contribuinte que adotar o comportamento ali preconizado ${ }^{136}$.

Noutros dizeres, trata-se de mecanismo regulatório que busca a indução dos destinatários da norma tributária a praticarem condutas desejáveis, sob o prisma do interesse coletivo. Deveras, o ente tributante abstém-se de exigir tributo (total ou parcialmente), como forma de estimular condutas desejadas pela ordem jurídica posta.

O intuito é, portanto, conceder suporte financeiro para a efetivação de atividades e projetos de interesse social, a promoção do equilíbrio regional, o fomento de setores

\footnotetext{
135 Os incentivos fiscais ora analisados não se confundem com os incentivos financeiros, que constituem empréstimo, pelo Estado, de valor com taxa de juros reduzida. É certo que a má prática do mencionado instrumento financeiro pode, de fato, mascarar verdadeira isenção ou redução do tributo, por vias transversas. Neste sentido, a doutrina e a jurisprudência têm considerado que os incentivos financeiros, cuja mensuração é feita com base no quantum da obrigação tributária, deve ser interpretado de acordo com a realidade concreta, ou seja, como incentivo fiscal. A par de tal anomalia, o incentivo financeiro é instrumento de auxílio estatal. Cláudia Dias Soares, tratando especificamente de incentivos financeiros concedidos no domínio ambiental, esclarece que "Quando o auxílio assume forma de empréstimo a taxa de juro bonificada as empresas têm um duplo benefício. Além da obtenção de capital a uma taxa de remuneração inferior à vigente no mercado, têm ainda a possibilidade de deduzir fiscalmente os juros pagos como despesas financeiras. Esta forma de ajuda é bastante utilizada, para evitar que a totalidade dos custos de adaptação das empresas por razões ambientais seja suportada pela generalidade dos contribuintes, como acontece no caso da atribuição de subsídios, com todas as dificuldades que essa situação acarretaria para o erário e para o cumprimento do PPP [princípio do poluidor-pagador]. A opção pela concessão de empréstimos em condições mais favoráveis do que as gerais permite promover a aceleração dos investimentos ambientais, através da distribuição no tempo dos custos a suportar pelo agente económico. $\mathrm{O}$ que, apesar de gerar um ganho financeiro para este, não provoca a sua desresponsabilização na resolução do problema" (Op. cit., p. 12).

${ }^{136}$ Acerca da necessidade de lei formal e específica para a introdução de incentivo fiscal, é claro o art. 150, $\S$ 6. ${ }^{\circ}$, da Carta Política de 1988, segundo o qual, "qualquer subsídio ou isenção, redução de base de cálculo, concessão de crédito presumido, anistia ou remissão, relativos a impostos, taxas ou contribuições, só podem ser concedidos mediante lei específica $[\ldots]$ ”.
} 
econômicos e de grupos de contribuintes estratégicos, dentre outros fins públicos de realce no ordenamento jurídico.

José Casalta Nabais ${ }^{137}$ conceitua os incentivos fiscais como "medidas de caráter excepcional instituídas para tutela de interesses públicos extrafiscais relevantes e que sejam superiores aos da própria tributação que impede".

Por seu turno, Geraldo Ataliba e José Artur Lima Gonçalves ${ }^{138}$, depois de salientar que os incentivos fiscais se manifestam sob diversas formas jurídicas (dentre elas, as isenções, alíquotas reduzidas, suspensão de impostos, manutenção de créditos, bonificações, créditos especiais), pontuam que o seu fim último consiste, sempre, em impulsionar ou atrair os particulares para o exercício das atividades reputadas como prioritárias pelo Estado. Dessa maneira, os particulares acabariam por se tornar participantes e colaboradores da realização das metas estipuladas como desejáveis ao desenvolvimento econômico e social, mediante a adoção de comportamento ao qual são condicionados.

De fato, os incentivos fiscais irão consubstanciar tratamento tributário abrandado, concedidos por meio de lei específica para tal fim, a um grupo de contribuintes, com intuito de alcançar o crescimento econômico, o aumento de saldo da balança comercial, o desenvolvimento do parque industrial nacional, a criação de vínculos formais de empregos, o incremento da competitividade dos produtos de fabricação nacional no mercado interno e externo, a proteção do meio ambiente etc.

Nesta perspectiva, nota-se que a riqueza que não é arrecadada pelo Estado não deixa de ser contributiva, haja vista destinar-se a fins públicos, diante do que se extrai desse instituto a noção de retributividade, responsável por lhe conferir fundamento e que deve estar consignada na correlata norma concessora ${ }^{139}$. É o que esclarece de forma lapidar Marcos Vinhas Catão ${ }^{140}$ :

É dentro de tal onerosidade ou de retributividade que encontraremos o substrato de validade do incentivo fiscal. É, por dizer, o seu "Fundamento" que deverá estar sempre difundido, expressa ou implicitamente na norma veiculadora do incentivo, e estar sempre associado aos valores insculpidos no texto constitucional.

\footnotetext{
${ }^{137}$ NABAIS, José Casalta. Op. cit., p. 633.

138 ATALIBA, Geraldo; GONÇALVES, José Artur Lima. Crédito-prêmio de IPI - direito adquirido recebimento em dinheiro. Revista de Direito Tributário, São Paulo, v. 15, n. 55, p. 167, jan.-mar. 1991.

${ }^{139}$ CATÃO, Marcos André Vinhas. Regime jurídico dos incentivos fiscais. Rio de Janeiro: Renovar, 2004. p. 31.

${ }^{140}$ Id., loc. cit.
} 
$[\cdots]$

Com todas as ressalvas possíveis, que permitam a fácil identificação dos motivos, razões e efetividade ao interesse geral, ao se optar pela concessão de incentivos fiscais legítimos, a diretriz política pretende que determinada atividade ou segmento social seja incentivado mediante a eliminação ou a redução do(s) tributo(s) aí incidente(s) [...].

Sem reparos, pois, a posição desse autor quanto à vinculação do incentivo fiscal à onerosidade e à necessidade de esta constar de forma explícita ou implícita na correlata norma instituidora do tratamento fiscal abrandado.

Importa destacar que, no auge do intervencionismo estatal do pós-guerra, o manejo dos incentivos fiscais multiplicou-se pelos diversos países do mundo, dentre eles França, Inglaterra, Alemanha, Itália, Estados Unidos e Brasil.

Diante disso, o controle do referido instrumental fez-se imprescindível, tendo a União Europeia, desde a década de setenta, buscado enfatizá-lo, em razão dos dilemas de ordem política, das negociações entre os diversos governos, dos lobbies da indústria e das instituições cada vez mais direcionadas ${ }^{141}$.

Ricardo Lobo Torres ${ }^{142}$ pontua que, nos idos de 1950 a 1970, concediam-se incentivos físcais "a mancheias na convicção de que tais benefícios conduziriam ao crescimento econômico". Segundo tal jurista, o desenvolvimento do país adquiriu lugar de destaque entre os princípios econômicos e jurídicos, razão pela qual o instituto em comento tornou-se a "panaceia para a riqueza das nações".

O uso exacerbado e sem o devido controle quanto ao cumprimento dos seus limites jurídico-constitucionais levou ao desgaste do referido instituto, que teve a sua eficácia fortemente contestada. Isto porque, em certos casos, observou-se o aumento do déficit público desacompanhado do desenvolvimento econômico e social perseguido.

Assim, a utilização indiscriminada dos citados instrumentos fez com que estes fossem equiparados a favores fiscais e privilégios odiosos concedidos a classes ou a pessoas, tal qual ocorria no Antigo Regime.

\footnotetext{
${ }^{141}$ LAVADAS, Kostas. Politics, subisidies and competition: the new politics of state intervention in the European Union. Cheltenham: Edward Elgar, 1999. p. 2.

142 TORRES, Ricardo Lobo. O princípio da isonomia, os incentivos do ICMS e a jurisprudência do STF sobre a guerra fiscal. In: MARTINS, Ives Gandra; ELALI, André; Marcelo Magalhães (Coord.). Incentivos fiscais: questões pontuais nas esferas federal, estadual e municipal. São Paulo: MP Ed., 2007. p. 327.
} 
Sucede que a conceituação de incentivos fiscais como privilégios fiscais afigura-se desprovida de amparo jurídico, já que a instituição de incentivos fiscais, sob a égide da Carta Política de 1988, consoante se verificará adiante ${ }^{143}$, está adstrita, dentre outros, ao princípio da isonomia e volta-se à concretização dos mais variados objetivos e fins fixados pelo aludido diploma.

Com efeito, o mestre pernambucano José Souto Maior Borges ${ }^{144}$, alicerçado na doutrina de Aliomar Baleeiro e de Seara Fagundes, sustenta a impossibilidade de se equiparar os incentivos fiscais a privilégios fiscais, ressaltando que a utilização dos termos "privilégio" ou "favor" consubstancia introdução de imprecisões e equívocos na linguagem científica. Para o aludido jurista, haveria uma radical incompatibilidade entre os antigos privilégios e o ordenamento constitucional vigente no país.

Nessa mesma linha, Marcos André Vinhas Catão ${ }^{145}$, na sua obra Regime jurídico dos incentivos fiscais, expõe os elementos configuradores do instituto em foco, atrelando a ideia de privilégio fiscal à ocorrência de uma distorção, que o torna ilegítimo. É o que se verifica da definição abaixo reproduzida:

[...] os "Incentivos Fiscais" são instrumentos de desoneração tributária, aprovados pelo próprio ente político autorizado à instituição do tributo, através de veículo legislativo específico, com o propósito de estimular o surgimento de relações jurídicas de cunho econômico. Trata-se de uma suspensão parcial ou total, mas sempre provisória, do poder que lhe é inerente, a fim de conformar determinadas situações, diferindo a tributação para o momento em que a captação de riquezas (imposição fiscal) possa ser efetuada de maneira mais efetiva, eficiente e justa.

Diferem de outras formas de desoneração, tais como as veras imunidades (liberdade religiosa, política etc.) não pelo emprego terminológico ou pela tipificação do veículo desonerativo, em razão de seu fundamento (estímulo econômico pela intervenção estatal), que há, todavia, de estar sempre atrelado aos princípios constitucionais, sob pena de se constituir em privilégio ilegítimo.

Além de equiparados a privilégios fiscais e a favores fiscais, o incentivo fiscal também vem sendo, tradicionalmente, tratado pela doutrina e pela jurisprudência com pouco rigor terminológico.

Ora se equipara o instituto em tela a benefício fiscal, alívio fiscal, auxílios de Estado, desoneração tributária, isenção etc., ora se define tal incentivo como espécie do

\footnotetext{
${ }^{143}$ Ver item 3.4.

${ }^{144}$ BORGES, José Souto Maior. Op. cit., p. 66.

${ }^{145}$ CATÃO, Marcos André Vinhas. Op. cit., p. 13.
} 
gênero benefício fiscal ou do gênero subvenção, tornando-se, pois, necessário tecer algumas considerações nesse sentido. Inicialmente, irá se abordar a acepção de benefício fiscal.

Com efeito, em obra fruto de dissertação de mestrado sobre o tema, Élcio Fiori Henriques $^{146}$, após salientar a dificuldade para uma definição satisfatória sobre a expressão "benefício fiscal", em face dos diversos enfoques e critérios que se podem conferir (finalidade, estrutura e efeito), salienta que o seu atributo fundamental consiste no "tratamento tributário menos gravoso para os contribuintes beneficiados, acarretando um recolhimento a menor de tributos". Arremata o autor:

Assim, o "benefício" auferido pelos contribuintes abrangidos por um benefício fiscal é exatamente a diminuição, parcial ou total, do valor do tributo a ser pago. Essa redução, em caráter excepcional, da tributação sobre determinado fato tem como resultado a manutenção da propriedade de determinados valores pelo particular, os quais, sem tal norma, a princípio, seriam pagos ao erário.

Como se pode observar da caracterização acima, a pedra de toque do benefício fiscal é o tratamento favorecido ao contribuinte contemplado pela norma. A identificação, todavia, demanda que se examine se o tratamento benéfico não está inserido na própria estrutura da exação, haja vista que o benefício fiscal deve corresponder a um tratamento que a excepciona.

Sob tal prisma, uma vez constatado um tratamento fiscal mais favorável do que o estipulado pela imposição regular, é possível classificá-lo como pertencente ao gênero "benefício fiscal", do qual o incentivo fiscal seria uma espécie, cujo tratamento abrandado estaria vinculado a um estímulo decorrente da sua função promocional.

Francisco Carlos Ribeiro de Almeida $^{147}$ considera que o incentivo fiscal consubstancia subconjunto dos benefícios tributários ${ }^{148}$. Para ele, um benefício fiscal

\footnotetext{
${ }^{146}$ HENRIQUES, Elcio Fiori. Os beneficios fiscais no direito financeiro e orçamentário: o gasto tributário no direito brasileiro. São Paulo: Quartier Latin, 2010. p. 28.

${ }^{147}$ ALMEIDA, Francisco Carlos Ribeiro. Uma abordagem estruturada da renúncia da receita pública federal. Revista do Tribunal de Contas da União, Brasília, v. 31, n. 84, p. 28, abr.-jun. 2000.

${ }^{148}$ Apesar de reconhecer que as expressões benefício fiscal e benefício tributário são equiparadas no País, Francisco Carlos Ribeiro Almeida faz a opção de distingui-los. Assim, o benefício tributário se restringiria aos gastos governamentais feitos mediante tratamentos tributários especiais para alcançar diversos objetivos econômicos (despesa indireta - receita), enquanto o benefício físcal abarcaria, além destes, os gastos diretos, com subvenções (despesa direta - despesa). Embora assista razão ao citado autor, este trabalho, ao mencionar a expressão benefício fiscal, somente fará referência aos benefícios concedidos com base na tributação, ainda que os efeitos da imposição, na prática, estejam aproximados à despesa direta, como no caso do crédito presumido.
} 
somente pode ser enquadrado como incentivo fiscal quando é "indutor de comportamento", estimulando condutas que visam a alcançar um alvo econômico ou social previamente firmado.

Neste contexto, o aludido autor traz como exemplo de incentivo fiscal a isenção do Imposto de Renda sobre os rendimentos reais advindos dos depósitos na caderneta de poupança pelos contribuintes pessoas físicas, visando mantê-los, ou atraí-los, nessas aplicações, a fim de evitar a excessiva canalização de recursos para o consumo, prejudicial à efetivação de determinado programa de estabilização ${ }^{149}$.

Nesta linha, outro subconjunto de benefícios fiscais seria formado pelos "alívios fiscais" (tax relief), que corresponderiam a benefícios voltados a atenuar situações adversas vivenciadas por certos contribuintes, as quais são relacionadas a condições que lhes foram postas de modo involuntário ${ }^{150}$. Seria o caso da isenção do desconto dos rendimentos da aposentadoria daqueles contribuintes acometidos por moléstia grave. Obviamente, ninguém se sentirá estimulado pela norma tributária a desenvolver uma doença cardíaca, por exemplo, para fazer jus a tal benefício.

Por seu turno, os auxílios de Estado, previstos expressamente no art. 87 do Tratado da antiga Comunidade Europeia, consubstanciam intervenções que, independentemente da forma manejada (isenções, redução parcial de tributo, concessão de empréstimos a juros baixos, subsídios), aliviam os encargos que normalmente pesam sobre o orçamento de uma empresa. Assim, os auxílios afiguram-se, para fins do citado dispositivo, um benefício de cunho patrimonial, concedido pelo Estado ou por outro sujeito que utilize recursos estatais, que se traduza numa vantagem dada para empresa e que provoque ou possa provocar uma modificação das condições concorrenciais no mercado comunitário ${ }^{151}$.

A intervenção em tela não pressupõe como contrapartida uma prestação específica do beneficiário em favor do ente estatal, havendo, pois, uma vantagem em relação às demais empresas não alcançadas pelo referido tratamento.

O instituto em destaque está relacionado a uma intervenção de caráter seletivo, de sorte que determinada medida de política econômica adotada de forma geral extrapola o

\footnotetext{
${ }^{149}$ ALMEIDA, Francisco Carlos Ribeiro. Uma abordagem estruturada... cit., p. 28.

${ }^{150}$ Id., loc. cit.

${ }^{151}$ SOARES, Cláudia Dias. Op. cit., p. 116-117.
} 
âmbito do citado art. 87 do Tratado da União Europeia, razão pela qual assevera Cláudia Dias Soares $^{152}$ :

\begin{abstract}
A repartição da carga fiscal pelos vários setores da economia através de despesas fiscais que se apliquem indiscriminadamente a todas as empresas não constitui auxílios estatais. Assim, medidas de caráter de pura técnica fiscal, como, e.g., a fixação de taxas de tributação, das regras de depreciação e amortização e em matéria de reporte de prejuízos, e medidas que têm um objetivo de política econômica geral, reduzindo ou aumentando a carga fiscal que onera determinados custos de produção, v.g., os ambientais, não são contrárias ao artigo 87 do Tratado $\mathrm{CE}$. O facto de alguns agentes se beneficiarem mais do que outros da referida medida não invalida esta afirmação. Apenas isenções que não se justifiquem "pela natureza ou pela economia do sistema" se podem considerar vedadas aos Estados-membros, a quem incumbe a prova de que o caráter distinto das medidas se justifica por tal racionalidade.
\end{abstract}

O Tribunal de Justiça da União Europeia ${ }^{153}$, em sede do Acórdão TCJ, de 27 de março de 1980 (processo 61/79), firmou que os auxílios estatais consubstanciam as decisões dos Estados-membros, que, buscando fins sociais e econômicos que lhes são próprios, por meio de decisões unilaterais e autônomas, colocam à disposição das empresas, ou de outros sujeitos de direito, recursos ou lhes facilitam vantagens destinadas a contribuir para a consecução dos objetivos econômicos e sociais perseguidos ${ }^{154}$.

Impõe-se repisar, pela sua importância, que, em qualquer situação, seja na aplicação dos alívios fiscais ou de qualquer outro instituto que venha a acarretar um tratamento tributário mais brando, está afastada a ideia de privilégio fiscal, visto que a sua concessão, longe de ser calcada na arbitrariedade, deve manter estrita obediência aos princípios e regras contemplados pelo respectivo ordenamento jurídico e, por óbvio, estar em total harmonia com os bens, valores e interesses constitucionais postos.

\footnotetext{
${ }^{152}$ SOARES, Cláudia Dias. Op. cit., p. 18-19.

${ }^{153}$ Cristóbal J. Borrero Moro, em artigo intitulado Límites del Derecho comunitario a los tributos ambientales, traz excertos da jurisprudência do Tribunal de Justiça da União Europeia, os quais se encontram, a seguir, reproduzidos: "Es jurisprudencia reiterada de este Tribunal de Justicia que el concepto de ayuda comprende no sólo prestaciones positivas como las subvenciones, sino también las intervenciones que, bajo formas diversas, alivian las cargas que normalmente recaen sobre el presupuesto de una empresa y que, por ello, sin ser subvenciones em el sentido estricto del término, son de la misma naturaleza y tienen efectos idénticos". Así, "una medida mediante la cual las autoridades públicas conceden a determinadas empresas una exención tributaria que, aunque no implique una transferencia de fondos estatales, coloque a los beneficiários en una situación financiera más favorable que a los restantes contribuyentes, constituye una ayuda de Estado em el sentido del apartado 1 del artículo 92 del Tratado", STJCE de 19-V-1999, C6/97, Italia/Comisión, aps. 15 y 16, respectivamente. Asi mismo, vid. STJCE de 15-III-94, Banco Exterior de España, C-387/92, Rec. p.I-877, ap. 14” (BORRERO MORO, Cristóbal José. Op. cit., p. 20).

${ }^{154}$ SOARES, Cláudia Dias. Op. cit., p. 16.
} 
Assim, por exemplo, a redução da tributação do contribuinte que se encontra desempregado seria classificada como um alívio fiscal, compatível com a ordem jurídica, homenageando, dentre outros, o princípio da capacidade contributiva. Não seria um incentivo fiscal, por não consubstanciar medida voltada a estímulo de comportamentos (descabido se falar, neste caso, em estímulo ao desemprego).

Já a desoneração da tributação incidente sobre a folha de salário ${ }^{155}$ pode ser classificada como lídimo incentivo fiscal, cujo escopo consubstancia o fomento dos vínculos empregatícios formais, a manutenção dos postos existentes e o estímulo à competitividade da indústria nacional, em conformidade com a ordem econômica constitucional, lastreada na valorização do trabalho e na livre-iniciativa.

Como já adiantado, o tema não é pacífico na doutrina e na jurisprudência, e, portanto, tal classificação dos benefícios fiscais como gênero do qual os incentivos e os alívios fiscais seriam espécies não é acolhida, seja por aqueles que defendem que os incentivos fiscais são sinônimos, seja por aqueles que os entendem como institutos diversos.

Noutro giro, cabe situar os incentivos fiscais em face dos auxílios de Estado acima descritos. De fato, os incentivos fiscais guardam semelhanças com os auxílios de Estado, porquanto estes conferem tratamento econômico vantajoso a determinado grupo de particulares, em virtude de objetivos econômicos e sociais. Citados auxílios, todavia, extrapolam a seara tributária, abarcando outras formas de intervenção estatal.

Em que pese essa busca por uma classificação do instituto em foco, deve-se atentar para a importante ponderação feita por André Elali, para quem, neste árido e nebuloso tema da classificação dos incentivos e suas figuras, o mais importante aspecto é "a expressão do benefício, tanto para os agentes econômicos quanto para as finanças

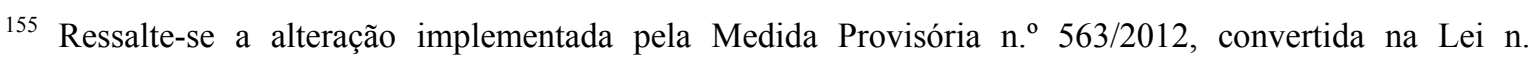
12.715/2012, que substituiu as contribuições previdenciárias incidentes sobre a folha de salários e demais rendimentos do trabalho, previstas nos incisos I e III do art. 22 da Lei n. ${ }^{\circ} 8.212 / 1991$, por nova contribuição incidente sobre a receita bruta ( $\S \S 12$ e 13 do artigo 195 da Constituição Federal) das empresas fabricantes dos produtos classificados na TIPI nos códigos referidos no Anexo da referida norma.

A mencionada mudança do modelo de tributação, inserida no contexto do Plano Governamental denominado "Brasil Maior", trouxe como motivação econômica o incentivo à formalização das relações de trabalho e à desoneração da folha de salários, para fomentar a competitividade da indústria brasileira, dado o cenário de crise econômica internacional.

Deveras, consta da Justificativa da MP n. ${ }^{\circ}$ 563/2012 que a contribuição sobre a receita promoverá uma desoneração fiscal e, por contemplar setores intensivos em mão de obra, viabilizará, em última análise, o aumento de vínculos formais de trabalho, com o alargamento da base de financiamento da Seguridade Social. 
públicas", sendo o ponto fundamental "a identificação da sua expressão econômica e financeira, bem como a sua eficiência para o sistema econômico"156.

Na mesma trilha encontra-se Marcos André Vinhas Catão ${ }^{157}$, que adverte:

[...] a sedução de enquadrar situações jurídico-objetivas em uma relação de gênero e espécie não deve servir para obstaculizar o desenvolvimento da proposta. Pela análise de alguns exemplos veremos que os incentivos fiscais se espraiam até mesmo sob situações onde não há efetivamente uma redução nominal na carga tributária.

[...] No caso dos incentivos fiscais, sobrevivem esses, aqui e internacionalmente, sob o uso de terminologia bastante semelhante, como, por exemplo, "benefícios fiscais", que podem a priori ser teleologicamente tomados por igual [...].

Elcio Fiori Henriques adota a expressão "benefício fiscal” de forma abrangente e sustenta que tal instituto pode ser identificado a partir de três critérios, a saber: i) finalístico; ii) pragmático e iii) jurídico-formal.

Nesse sentido, com base no critério da finalidade, os benefícios fiscais surgem sempre que se estiver diante de norma tributária que se volta a fím diverso do arrecadatório, e buscam fins outros, a exemplo dos extrafiscais. Assim, os benefícios seriam diferenciados por visarem à indução de comportamentos.

Constatada a grande dificuldade de identificação da finalidade da norma, propõe-se a adoção do critério pragmático, que irá reconhecer um benefício fiscal com base no efeito indutor por ele produzido. Assim, verificado o efeito indutor de uma norma, passa-se a examinar se esta irá atender aos princípios e regras constitucionais que tratam das intervenções econômicas.

Nota-se, também, ser árdua a tarefa de identificar o efeito indutor das normas, já que, nos casos de tratamentos tributários de maior complexidade, não se vislumbra ao certo o resultado apresentado. O critério acima pode ser visualizado com mais facilidade quando se explicitam, como contraponto, situações em que não há chance de haver nenhum efeito desencadeado pela norma, uma vez que veiculam tratamentos favorecidos a fatos cuja ocorrência independe da vontade do contribuinte.

Por fim, o critério jurídico-formal para distinção dos benefícios fiscais refere-se ao entendimento de que os tributos possuem um apanhado de normas que determina a sua

\footnotetext{
${ }^{156}$ ELALI, André. Op. cit., p. 57-58.

${ }^{157}$ CATÃO, Marcos André Vinhas. Op. cit., p. 11-12.
} 
regra geral de incidência, denominado benchmark. A verificação de um tratamento físcal favorecido situado fora do padrão estipulado irá revelar a existência de um benefício fiscal.

Os critérios para a identificação dos benefícios fiscais acima sintetizados na obra referenciada demonstra a possibilidade de adoção dos termos incentivos físcais e benefícios fiscais como sinônimos, sendo o estímulo apenas um dos critérios para a identificação do benefício fiscal.

A classificação de gênero e espécie entre benefícios fiscais e incentivos fiscais é afastada quando são realçadas as características peculiares dos institutos. Nesta senda é que Maria de Fátima Ribeiro e Marcelo Diniz ${ }^{158}$ fazem a distinção dos institutos, defendendo que o benefício fiscal seria estático, já que a concessão, em regra, ocorre por força de um fato consumado e tem por objetivo atenuar uma situação gravosa do contribuinte, enquanto o incentivo fiscal é dinâmico e programático, pois busca resultados de caráter extrafiscal ao longo do tempo, voltado ao bem comum.

A concepção adotada pelo presente estudo é a de não usar, indiscriminadamente, os termos benefício fiscal e incentivo fiscal como sinônimos. O incentivo fiscal seria o tratamento tributário abrandado conferido a um determinado grupo de contribuintes, cujo traço peculiar consiste na sua função indutora e na existência de uma contraprestação por parte do incentivado, vinculada de forma expressa ou implícita pela norma concessora do estímulo.

Assim, por exemplo, o incentivo fiscal conferido ao empresário que irá instalar uma indústria nova em determinada região pressupõe, em regra, que haja a redução da carga tributária (concessão de depreciação acelerada do maquinário adquirido, crédito presumido), ficando a cargo do contribuinte incentivado a realização de investimentos no empreendimento, o aumento da produção de determinado produto e a criação de certo número de vínculos empregatícios.

Por seu turno, o benefício fiscal seria um tratamento tributário atenuado voltado tão somente à concretização de princípios, bens e valores constitucionais, sem a pretensão de influenciar o comportamento do contribuinte beneficiado. O tratamento diferenciado seria justificado pelo apelo vinculado ao substrato a que se pretende favorecer, ou seja, em função da importância do bem juridicamente tutelado que se irá proteger.

${ }^{158}$ RIBEIRO, Maria de Fátima; DINIZ, Marcelo de Lima Castro. O direito ao crédito-prêmio do IPI. In: PEIXOTO, Marcelo Magalhães (Coord.). IPI: aspectos jurídicos relevantes. São Paulo: Quartier Latin, 2003. p. 298. 
Desse modo, determinada isenção concedida aos contribuintes acometidos com doenças graves não se presta a estimular a contração de enfermidade, mas a proteger contribuintes, em atendimento aos ditames constitucionais.

Vale ressaltar, todavia, que a classificação e as distinções não podem ser claramente inferidas da legislação pátria ora em vigor.

Com efeito, a análise realizada no âmbito constitucional não é muito esclarecedora. Observa-se o manejo, ao longo do texto, dos mais distintos termos aceitos como integrantes do conceito de incentivos e benefícios fiscais, tais como "isenções, anistias, remissões, crédito presumido, redução de base de cálculo etc.", tendo o Legislador constituinte acrescentado, em muitas ocasiões, o conectivo "ou" para separar os incentivos dos benefícios fiscais, o que revela, a um só tempo, a inexistência de severidade extremada nessa conceituação e a provável concepção de tais institutos como categorias diversas.

Deveras, o art. 155, $2^{\circ} .^{\circ}$, XII, g, e o art. 156, $\S 3 .^{\circ}$, III, valem-se dos termos "isenções, incentivos e benefícios fiscais" para determinar que cabe à lei complementar instituí-los e revogá-los. Por seu turno, o art. 195, § 3. ${ }^{\circ}$, proíbe que os contribuintes em débito com o sistema da seguridade social recebam "benefícios ou incentivos fiscais ou creditícios".

De fato, os incentivos fiscais não tiveram a sua disciplina estruturada pelo ordenamento jurídico pátrio. Há menções no texto da Lei Maior, bem como foram cunhadas a Lei Complementar de n. ${ }^{\circ}$ 24/1975 (que visa a regular as normas gerais aplicáveis aos incentivos físcais, no âmbito do ICMS) e a Lei Complementar n. ${ }^{\circ}$ 101/2000 (voltada ao controle da gestão físcal), cujo conteúdo pode ser extraído e aplicado à luz dos princípios e regras constitucionais que balizam a tributação ${ }^{159}$.

No que tange especificamente à Lei de Responsabilidade Fiscal (LC n. ${ }^{\circ}$ 101/2000), verifica-se que um passo adiante na identificação do conteúdo e alcance dos mencionados institutos foi dado. Ressalte-se o teor do art. $14, \S \S 1 .^{\circ}$ e $2 .^{\circ}$, abaixo reproduzido para melhor análise:

Art. 14. A concessão ou ampliação de incentivo ou benefício de natureza tributária da qual decorra renúncia de receita deverá estar acompanhada de estimativa do impacto orçamentário-financeiro no exercício em que deva iniciar sua vigência e nos dois seguintes, atender ao disposto na lei de diretrizes orçamentárias e a pelo menos uma das seguintes condições:

\footnotetext{
${ }^{159}$ Vale ressaltar, todavia, que tramitam no Congresso Nacional propostas de Lei Complementar que visam a alterar os parâmetros postos pela Lei Complementar n. ${ }^{\circ} 24 / 1975$.
} 


\section{$[\ldots]$}

$\S 1 .^{\circ}$ A renúncia compreende anistia, remissão, subsídio, crédito presumido, concessão de isenção em caráter não geral, alteração de alíquota ou modificação de base de cálculo que implique redução discriminada de tributos ou contribuições, e outros benefícios que correspondam a tratamento diferenciado.

\section{$[\ldots]$}

$\S 3 .^{\circ} \mathrm{O}$ disposto neste artigo não se aplica:

I - às alterações das alíquotas dos impostos previstos nos incisos I, II, IV e V do art. 153 da Constituição, na forma do seu $\S 1$. $^{\circ}$;

II - ao cancelamento de débito cujo montante seja inferior ao dos respectivos custos de cobrança.

Consoante se abordará com mais vagar adiante ${ }^{160}$, a renúncia de receita de que trata a norma em foco consubstancia o efeito financeiro dos benefícios fiscais/incentivos fiscais, de modo que o art. 14, ao fazer menção à "renúncia", no bojo do seu $\S 1 .^{\circ}$, e ao elencar as figuras da isenção, alteração de alíquota, base de cálculo etc., trata, em verdade, dos aludidos institutos. É o que também observa Elcio Fiori Henriques ${ }^{161}$ :

Da leitura do supracitado $\S 1^{\circ}$, verifica-se prontamente o uso questionável da expressão"renúncia" para definir os benefícios fiscais. Isso porque o caput do artigo, como visto, define que o conceito de "renúncia de receita" se refere ao efeito financeiro da concessão dos "benefícios fiscais", motivo pelo qual não se pode confundir os dois institutos. [...]

Ademais, tal dispositivo, longe de trazer uma definição estrita de "renúncia de receita", utiliza a expressão "a renúncia compreende [...]", sendo, portanto, apenas uma enumeração não exaustiva de benefícios fiscais dos quais decorre renúncia de receita.

Note-se, ainda, que o mencionado diploma legal contribui para a construção da conceituação de benefícios fiscais e de incentivos fiscais, ao adotar como critério para sua identificação a ocorrência da diminuição "discriminada de tributos ou contribuições" e o "tratamento diferenciado", ou seja, estipula que constituem normas que adotam um tratamento tributário diverso da norma geral da incidência de um tributo.

\footnotetext{
${ }^{160}$ Ver item 3.4.6.

${ }^{161}$ HENRIQUES, Elcio Fiori. Op. cit., p. 141-142.
} 
Assim, utiliza como critério o "jurídico-formal", que, como visto, define que os benefícios são exceções à norma tributária de referência, tal como desvios à norma padrão, adotada como benchmark ${ }^{162}$.

Saliente-se, todavia, que não é tarefa fácil identificar em que situação determinado tratamento tributário diferenciado e redução discriminada de tributo faz parte da estrutura da norma ou consiste num desvio a configurar um benefício fiscal. Cabe analisar a desoneração discriminada de forma pormenorizada e à luz do ordenamento pátrio como um todo para avaliar se a diferenciação está ou não incluída na estrutura da norma de incidência do tributo respectivo.

A respeito da dificuldade de identificar os benefícios fiscais, pontua Marcos de Freitas Gouvêa ${ }^{163}$ :

\begin{abstract}
A tarefa de delimitar os benefícios fiscais parece realmente difícil. Nada impede que a política pública seja levada a cabo por variações tributárias que não fujam aos contornos padrões dos impostos. Além disso, é problemático alcançar a norma padrão, básica, do tributo, seu modelo abstrato, seja sob o enfoque funcional ou estrutural. Entretanto, o tema não perde em interesse ou em utilidade, uma vez que a distinção pretendida pode ser intuída ou definida por ato político de vontade.

Para atender aos anseios da lei de responsabilidade fiscal (art. 14), tendo em vista que seu objetivo é o controle da gestão pública, o benefício fiscal deve ser entendido de maneira ampla, incluindo todos os institutos exonerativos tecnicamente distintos. Isso porque se trata dos efeitos fiscais dos benefícios, vale dizer, a apuração do montante que deixou de ingressar nos cofres públicos.
\end{abstract}

Cumpre notar que a Receita Federal do Brasil produziu estudo denominado "Estudos Tributários 12 - Gastos Governamentais Indiretos, de Natureza Tributária (Gastos Tributários - Conceituação)", contribuindo para a análise da conceituação de benefício fiscal ${ }^{164}$.

Nos termos de tal documento, os fins que levam à desoneração fiscal são:

a) simplificar e/ou diminuir os custos da administração;

b) promover a equidade;

c) corrigir desvios;

\footnotetext{
${ }^{162}$ HENRIQUES, Elcio Fiori. Op. cit., p. 144-145.

${ }^{163}$ GOUVÊA, Marcus de Freitas. Op. cit., p. 210.

${ }^{164}$ HENRIQUES, Elcio Fiori. Op. cit., p. 168-169.
} 
d) compensar gastos realizados pelos contribuintes com serviços não atendidos pelo governo;

e) compensar ações complementares às funções típicas de estado desenvolvidas por entidades civis;

f) promover a equalização das rendas entre regiões;

g) incentivar determinado setor da economia.

$\mathrm{O}$ referido estudo estabelece que, "nos casos das alíneas 'd', 'e', 'f' e 'g', as desonerações irão se constituir em uma alternativa às ações políticas de governo, ações com objetivos de promoção de desenvolvimento econômico ou social, não realizadas no orçamento e sim por meio do sistema tributário, compondo o que se convencionou denominar de gastos tributários”.

O mencionado documento passou a utilizar a expressão gasto tributário em substituição à expressão benefício fiscal, por entender que aquela realça o caráter orçamentário do instituto, e defende que há gasto tributário quando a desoneração: i) promove desvios fora do âmbito da correção de desvios, da promoção de equidade ou da simplificação da tributação e ii) tem como escopo a realização de ação do governo.

Por outro lado, quando a desoneração está dentro dos mencionados âmbitos da correção de desvios, da promoção de equidade e da simplificação da tributação é considerada como parte integrante da própria estrutura tributária.

Elcio Fiori Henriques, ao comparar o critério para a identificação do benefício fiscal adotado pela Receita Federal ao adotado pela Lei de Responsabilidade Fiscal, frisa que, enquanto a primeira insere o caráter finalístico na identificação do benefício fiscal, a última adota unicamente o critério lógico-formal, de modo que, para a lei complementar, as normas benéficas que determinam um tratamento discriminado de um grupo de contribuintes seriam um desvio à norma padrão de incidência tributária configuradora do benefício fiscal.

Nessa linha, defende o autor que a conceituação realizada pela Receita Federal do Brasil extrapola o regime jurídico delineado pela lei complementar e também pela Constituição. 
O trabalho ora empreendido, por estar voltado ao estudo do incentivo fiscal ambiental, que atende cumulativamente ao critério para definição de gasto tributário delineado pela Receita Federal e pela Lei de Responsabilidade, não aprofundará a questão da diferença entre tais critérios.

Cumpre pontuar, todavia, que o critério contido na Lei de Responsabilidade Fiscal, que se interpreta como o "lógico-formal", deve ser aplicado em consonância com o ordenamento jurídico pátrio. Isto porque não são todos os tratamentos diferenciados que podem ser tidos como um benefício fiscal, estando afastado qualquer tipo de classificação automática.

A prevalecer tal entendimento, inúmeras disposições que estipulam regras que fazem parte da própria estrutura constitucional e legal da imposição tributária seriam tidas como benefícios fiscais.

Neste contexto é que Luís Eduardo Schoueri ${ }^{165}$, na sua obra que aborda as normas tributárias indutoras, criticou o antigo "demonstrativo de benefícios tributários" elaborado pela Receita Federal do Brasil para o ano de 2001, em que foram listadas como benefício tributário as normas que i) promovessem redução da arrecadação potencial, ii) aumentassem a disponibilidade econômica do contribuinte, e iii) consubstanciassem exceção à norma de referência do tributo ou alcance, exclusivamente, determinado grupo de contribuintes.

Ressaltou o aludido autor que o critério da "exceção à regra que referencia o tributo" é deveras insuficiente para a identificação dos incentivos, porquanto não há critérios para a aferição da "normalidade" da tributação. Como não é possível saber se há tributação normal, não há como se identificar a exceção.

Observou, assim, que houve a inclusão de normas que não seriam benefício, concluindo ser necessária a investigação da função indutora das normas para uma adequada concretização dos objetivos constitucionais. Ressalte-se a dicção do autor em comento $^{166}$ :

O resultado é que além de indiscutíveis normas tributárias indutoras, como o são as que tratam de incentivos regionais, incluíram-se no relatório valores concernentes à isenção sobre bagagens (que dificilmente se enquadrariam como norma indutora, a menos que se entenda que o Poder Público pretende incentivar o turismo para o exterior). Tampouco

\footnotetext{
${ }^{165}$ SCHOUERI, Luís Eduardo. Normas tributárias indutoras e intervenção econômica, cit., p. 60.

${ }^{166}$ Id., loc. cit.
} 
se incluem entre as normas tributárias indutoras (e sequer como benefício de qualquer índole) as deduções efetuadas pelas pessoas físicas, como despesas médicas também incluídas no referido relatório. Fica clara, assim, a importância de se destacarem os efeitos indutores da norma tributária, para melhor consecução do desiderato constitucional.

Tal crítica é pertinente, porquanto não se pode considerar como incentivo fiscal a redução do tributo que se presta apenas a ajustar a imposição fiscal aos princípios constitucionais que o conformam.

Vale ressaltar que, em relação à parcela isenta do Imposto de Renda, que também foi incluída, à época, no aludido demonstrativo, poder-se-ia dizer que há um desvio da norma geral de tributação da riqueza, porém este desvio não se verifica na prática, já que a desoneração da aludida parcela está alinhada com a estrutura constitucional do tributo em foco, que rechaça a tributação do mínimo existencial e impõe a progressividade.

Não há dúvidas de que, em tal caso, a redução tributária está a promover um ajuste à capacidade contributiva, à progressividade e à equidade, de modo a afastar a sua classificação como benefício/incentivo fiscal. Retirar da incidência do IRPF determinada parcela mínima constitui, pois, tratamento que efetivamente deveria ter sido dado, diante dos princípios e regras que conformam o ordenamento jurídico nacional.

Para a verificação de tais desvios, indispensável a análise por meio de critérios da razoabilidade e da proporcionalidade, os quais, de plano, afastariam da estrutura da norma de incidência do IRPJ, por exemplo, lei que concedesse isenção de tributo a empresas que utilizassem insumos, maquinário e demais materiais e serviços de origem nacional.

Não se olvida que é objetivo do Estado fomentar a produção nacional e adotar medidas que amenizem os impactos causados pela concorrência estrangeira. Contudo, tais fundamentos não justificam que se classifique tal desoneração hipotética como decorrente da própria estrutura da incidência tributária correlata, de forma que, havendo a sua instituição, esta deveria ser classificada como um incentivo fiscal.

Neste contexto, constata-se notável evolução no atual critério adotado pela Receita Federal do Brasil para identificação dos gastos tributários, acima mencionado.

Feitas tais considerações acerca do incentivo fiscal e demais institutos afins, passase agora ao exame das subvenções e sua diferenciação de tais institutos. 


\subsection{Subvenção}

As subvenções são transferências diretas de recursos financeiros do Estado para entidades públicas ou privadas, cuja principal característica é a inexistência de contraprestação.

No Brasil, a Lei n. ${ }^{\circ} 4.320 / 1964$ dispõe, no $\S 3^{\circ}$ do art. 12, que as subvenções constituem "transferências destinadas a cobrir despesas de custeio das entidades beneficiadas". De acordo com a finalidade, podem ser de duas espécies: as subvenções sociais, "as que se destinem a instituições públicas ou privadas de caráter assistencial ou cultural, sem finalidade lucrativa" (art. 16), e as subvenções econômicas, "as que se destinem a empresas públicas ou privadas de caráter industrial, comercial, agrícola ou pastoril" (art. 18).

A doutrina ressalta a vinculação de tal auxílio financeiro a uma justificativa de ordem pública. Com efeito, Régis Fernandes de Oliveira ${ }^{167}$ conceitua subvenção como um auxílio financeiro que se encontra previsto no orçamento, a fim de ajudar as entidades públicas ou privadas a desenvolver atividades assistenciais, culturais e empresariais.

Elcio Fiori Henriques ${ }^{168}$, nessa mesma linha, aduz que as subvenções constituem "transferências de recursos diretas do Estado, sem contraprestação, para prestar auxílios financeiros a determinado beneficiário público ou privado, com base em justificativa de ordem pública".

Deveras, a subvenção tem natureza jurídica de incentivo financeiro ou creditício para concretização de finalidade definida, sujeitando-se às normas de direito financeiro.

Vale assinalar que o termo subvenção costuma ser tratado como sinônimo de subsídio, embora possa este último ser incluído no conceito mais amplo de subvenção ${ }^{169}$. Com efeito, seriam os subsídios espécies de subvenção, cujo traço peculiar consistiria no objetivo de fomentar determinada atividade econômica.

Por sua vez, o exame comparativo entre a subvenção e o incentivo fiscal leva à constatação de que, sob o ponto de vista financeiro, o incentivo fiscal pode ter efeito de um

\footnotetext{
${ }^{167}$ OLIVEIRA, Régis Fernandes. Curso de direito financeiro. São Paulo: RT, 2006. p. 371.

${ }^{168}$ HENRIQUES, Elcio Fiori. Op. cit., p. 36.

169 TORRES, Ricardo Lobo. Tratado de direito constitucional, financeiro e tributário. Rio de Janeiro: Renovar, 1999. v. 3, p. 367.
} 
pagamento a fundo perdido (isenção fiscal) ou de um crédito sem juros (depreciação acelerada), razão pela qual Luís Eduardo Schoueri admite considerá-lo como uma forma de subvenção (subvenção indireta) ${ }^{170}$.

Todavia, consoante já assinalado, o conceito jurídico de subvenção demanda a transferência de recursos financeiros pelo Estado, o que não é verificado no caso dos incentivos fiscais, quando estes consubstanciam uma abstenção do Estado de receber determinada receita tributária.

Insta pontuar que, quando o incentivo fiscal adota a forma de crédito presumido, identifica-se a sua maior aproximação com a subvenção ${ }^{171}$.

Portanto, a despeito de serem juridicamente distintos, o incentivo fiscal e a subvenção, sob o aspecto econômico, produzem efeitos semelhantes, uma vez que o particular acaba por ser contemplado com recursos pertencentes ao erário.

Abstraindo-se, pois, a análise puramente formal dos institutos, nota-se que, para se alcançar determinado efeito a partir da disponibilização de recursos financeiros, o Estado poderá valer-se tanto de incentivo fiscal quanto de subvenção.

Calha consignar que em algumas hipóteses a concessão da subvenção é realizada atrelando-se o cálculo do montante transferido ao valor da obrigação tributária, ocorrendo a utilização do recurso dentro da sistemática da própria relação tributária. Em tais situações, é nebulosa a definição de qual é efetivamente o instituto que se está a manejar.

Assim, por exemplo, se o ente tributante, com o objetivo de fomentar uma atividade econômica, concede, a título de "subvenção", uma redução de 50\% de um imposto X por 10 anos, não se pode admitir que a estruturação formal de uma subvenção ofusque a clara realidade de que se estar, efetivamente, diante de um incentivo fiscal, com evidente renúncia de receita.

Em situação diversa, poder-se-ia cogitar de efetiva subvenção, ainda que com utilização como parâmetro o percentual de $50 \%$ do imposto $\mathrm{X}$, caso o contribuinte extinguisse a obrigação tributária integralmente, havendo, contudo, posterior repasse direto da metade do valor recolhido, por intermédio de determinada agência de fomento.

Como se vê, a depender do modelo que é construído, o incentivo financeiro (subvenção) pode consubstanciar, na prática, um incentivo fiscal.

\footnotetext{
${ }^{170}$ SCHOUERI, Luís Eduardo. Normas tributárias indutoras e intervenção econômica, cit., p. 57.

${ }^{171}$ Id., loc. cit.
} 
Importa destacar que, em regra, os países menos desenvolvidos utilizam incentivos tributários em detrimento de subsídios diretos, haja vista a indisponibilidade de recursos para injetar diretamente na economia. Isto não quer dizer que os países desenvolvidos, por deterem maior disponibilidade financeira, não manejem os incentivos tributários.

De fato, a opção por incentivo ou subsídio direto encontra-se mais relacionada a uma questão de política ou técnica. Apesar de haver quem defenda que há menor transparência e visibilidade quando da concessão de incentivos fiscais, a utilização de métodos de controle, como a publicação da lista de medidas e o seu impacto financeiro, é suficiente para a superação de tal suposta desvantagem ${ }^{172}$.

Nesta perspectiva, no Brasil, em que o tributo se submete às normas constitucionais da ordem tributária e econômica, constituindo instrumento de intervenção sobre a economia, é possível a opção técnica e/ou política pela adoção dos incentivos fiscais.

Cumpre, no entanto, observar todos os regramentos que lhes são impostos, especialmente a indispensável previsão em lei e a necessidade de exame dos impactos orçamentários (art. 14 da Lei de Responsabilidade Fiscal) ${ }^{173}$.

Além disso, a opção eleita deverá corresponder à efetiva promoção do objetivo econômico e social visado, de modo que cumpre avaliar, à luz da realidade de cada país, o instrumento que melhor realiza tal mister.

Em qualquer hipótese, seja subvenção direta ou incentivo fiscal, a lei instituidora da correlata intervenção deverá cuidar para que haja igualdade, respeito à livre concorrência e obtenção dos fins a que se destinam. A esse respeito, dignas de transcrição são as lições de André Elali ${ }^{174}$ :

[...] a distinção entre os mecanismos aplicados pelos diferentes países revela a cultura de cada sistema. Não é possível, pois, importar para o Brasil exemplos de outros países sem analisar a estrutura econômica e a cultura locais. Veja-se que as decisões dos agentes econômicos, nesse contexto, variam de Estado para Estado, o que comprova essa assertiva.

Há, entretanto, uma certa generalização de que a prática de subvenções, por qualquer de suas espécies, precisa de um controle em face de dois aspectos principais: i) tratar todos igualmente, na medida da chamada isonomia seletiva, em face da proteção do regular funcionamento do mercado (livre- iniciativa e livre concorrência, especialmente); ii)

\footnotetext{
${ }^{172}$ ELALI, André. Op. cit., p. 127.

${ }^{173}$ Ver itens 3.4.2. e 3.4.6.

${ }^{174}$ ELALI, André. Op. cit., p. 128.
} 
controlar a despesa pública, nas facetas da diminuição de receita ou de aumento de despesa em termos diretos. Por tais questões, impõe-se o exame cuidadoso das políticas indutoras a partir de elementos complexos, que abrangem a ordem econômica pela própria natureza.

Tecidas as devidas considerações acerca da acepção de incentivo físcal e da sua distinção da subvenção, cabe, nesta altura, investigar as formas em que tal instituto pode se manifestar.

\subsection{Incentivos fiscais e algumas formas de manifestação}

Restou evidenciado que o incentivo fiscal consubstancia uma intervenção estatal que busca estimular comportamentos concretizadores dos fins constitucionais, por meio da instituição de normas indutoras que concedem tratamento tributário mais brando ao contribuinte.

Para tanto, o Estado detém um vasto leque de possibilidades, podendo ser criadas normas que veiculam variados formatos de tributação atenuada, seja por meio do afastamento total ou parcial da obrigação tributária, seja mediante a postergação da ocorrência do fato gerador do tributo, seja, ainda, por meio da concessão de crédito presumido, entre outras figuras. É o que se passa a demonstrar.

\subsubsection{Isenção}

Uma das formas de criar um incentivo fiscal é afastar a tributação incidente sobre atividades e situações que se pretende estimular.

Com efeito, a isenção consiste num procedimento técnico-jurídico, por intermédio do qual os entes tributantes editam normas que afastam do campo da incidência da norma determinada pessoa ou objeto. Instituem, assim, regra jurídica, sem a qual a pessoa ou o objeto por ela isentado seria alcançado pela tributação regular.

Antes de aprofundar o seu exame, entretanto, serão tecidas considerações acerca dos institutos da não incidência, da imunidade e da isenção imprópria. 
Inicialmente, distinguiremos a isenção do instituto da não incidência pura $e$ simples $^{175}$, que se refere a fatos totalmente alheios à regra jurídica de tributação. No dizer de Alfredo Augusto Becker ${ }^{176}$, a não incidência "significa que o acontecimento destes ou daqueles fatos é insuficiente, ou excedente, ou simplesmente estranho para a realização da hipótese de incidência da regra jurídica de tributação”.

Ruy Barbosa Nogueira ${ }^{177}$ especifica a hipótese de não incidência como “[...] o fato de a situação ter ficado fora dos limites do campo tributário, ou melhor, a não ocorrência do fato gerador, porque a lei não descreve a hipótese de incidência". Arrematando o tema, posiciona-se, nessa mesma linha, Luciano Amaro ${ }^{178}$ : "Todos os fatos que não têm a aptidão de gerar tributos compõem o campo da não incidência (de tributo)".

Cumpre, ainda, diferençar a isenção de outro instituto com o qual não se confunde, a saber, a imunidade, que consiste em hipótese de não incidência qualificada por imposição constitucional.

Ao examinar a etimologia do termo imunidade, Bernardo Ribeiro Morais ${ }^{179}$ aduz que imunitas, ou exonerado de munus, designa a liberação de "múnus" ou encargos, dispensa de carga, de ônus, de obrigação ou até de penalidade. Portanto, aquele que não está submetido ao munus tem imunidade (munus público é aquilo que procede da autoridade pública, ou da lei, e obriga o indivíduo a certos encargos).

A Lei Maior concebe as imunidades como regras jurídicas constitucionais incluídas no rol das limitações constitucionais ao poder de tributar do Estado, as quais, com o objetivo de proteger valores considerados de relevo para o ordenamento jurídico pátrio, excluem expressamente da competência impositiva fiscal do Estado determinadas pessoas, bens e situações.

As aludidas desonerações físcais específicas possuem como justificativa e fundamento a proteção e o fomento de determinados valores tidos como de importância para a sociedade, tais como a igualdade entre os entes federados, a cultura, a liberdade: de

\footnotetext{
175 “[...] é conceito relacionado com o de incidência. Ocorre incidência da lei tributária quando determinada pessoa ou coisa se encontra dentro do campo coberto pela tributação; dá-se não incidência, diversamente, quando determinada pessoa ou coisa se encontra fora do campo de incidência da regra jurídica de tributação" (BORGES, José Souto Maior. Op. cit., p. 183).

${ }^{176}$ BECKER, Alfredo Augusto. Teoria geral do direito tributário. 3. ed. São Paulo: Lejus, 1998. p. 276.

${ }^{177}$ NOGUEIRA, Barbosa, Ruy. Op. cit., p. 171.

${ }_{178}^{17}$ AMARO, Luciano da Silva. Direito tributário brasileiro. 15. ed. São Paulo: Saraiva, 2009. p. 263.

${ }^{179}$ MORAES, Bernardo Ribeiro de. Imunidades tributárias. In: MARTINS, Ives Gandra da Silva (Coord.). Imunidades tributárias. São Paulo: Centro de Extensão Universitária; RT, 1998. p. 105. (Coleção Pesquisa tributária, Nova Série, 4.)
} 
imprensa, política, de culto, entre outras, consoante se verifica, por exemplo, do art. 150, VI, da Constituição Federal, o qual torna imune à tributação bens, situações e pessoas vinculadas aos mencionados valores.

Trata-se de restrição à competência tributária imposta pelo legislador constituinte, estando, pois, o instituto em tela no campo da dicção constitucional negativa ${ }^{180}$. Pela precisão e lucidez das palavras, cumpre transcrever as lições do professor Estevão Horvath $^{181}$ sobre o tema:

Deveras, as chamadas "limitações constitucionais ao poder de tributar" são, em rigor, parte da configuração da competência tributária, isto é, além da linguagem constitucional positiva que outorga às pessoas políticas a possibilidade de instituírem tributos, existe ao seu lado a diç̧ão negativa, que proíbe a criação destes com relação a certas pessoas ou bens (as denominadas imunidades tributárias) ou estabelece os princípios a que estará sujeito o exercício da competência. Em outras palavras, a moldura constitucional que outorga a competência tributária é estruturada pelos dados positivos e negativos que o Texto Supremo traz.

Tratando desse instituto, Pontes de Miranda ${ }^{182}$ assevera que "é regra jurídica no plano da competência dos poderes públicos - obsta à atividade legislativa impositiva, retira ao corpo que cria impostos qualquer competência para pôr, na espécie”.

Por fim, salientem-se as ponderações de Celso Cordeiro Machado ${ }^{183}$ sobre o tema, expostas em tese para provimento da cátedra de Finanças e Direito Financeiro da Faculdade de Direito da UFMG:

As imunidades abrangem, de modo geral, aquelas situações que estariam normalmente, naturalmente, conceitualmente incluídas entre os fatos geradores. Elas se traduzem em limitações ao poder de tributar ou em contrações horizontais dos campos de incidência que decorreriam das projeções espontâneas e totais dos fatos geradores.

\footnotetext{
${ }^{180}$ Aires F. Barreto e Paulo Ayres Barreto, considerando que a competência tributária já nasce delimitada na própria Constituição, irão defender que aos entes tributantes só podem atuar no âmbito que lhes foi outorgado, e que as imunidades definem uma área textualmente subtraída à competência legislativa (em matéria tributária), não havendo como se onerar as situações imunes à tributação (BARRETO, Aires F.; BARRETO, Paulo Ayres. Imunidades tributárias: limitações constitucionais ao poder de tributar. São Paulo: Dialética, 1999. p. 9). Por sua vez, Yoshiaki Ichihara, em obra originada de tese de doutoramento sobre o assunto em foco, assevera que esferas delimitadas pelas imunidades são "áreas de incompetência, não existindo para o legislador competente fundamento de validade nem atribuição para legislar sobre tal campo ou matéria, inexistindo alguma possibilidade, por lei, de criar uma hipótese de incidência" (ICHIHARA, Yoshiaki. Imunidades tributárias. São Paulo: Atlas, 2000. p. 124).

${ }^{181}$ HORVATH, Estevão. O princípio do não confisco no direito tributário. São Paulo: Dialética, 2002. p. 38.

${ }^{182}$ PONTES DE MIRANDA, Francisco Cavalcanti. Questões forenses. Rio de Janeiro: Borsoi, [s.d.]. t. 3, p. 364.

${ }^{183}$ MACHADO, Celso Cordeiro. Limites e conflitos de competência tributária no direito brasileiro. Belo Horizonte: [s.n.], 1968. p. 41.
} 
Do quanto até aqui exposto sobre as imunidades tributárias, é possível concluir que tais normas consubstanciam verdadeiras interdições ao poder de tributar com potencial para aplicação imediata, exercitável por qualquer contribuinte que se encontre nas posições por elas protegidas.

Por sua vez, a figura exonerativa que mais interessa a esse estudo, a isenção, longe de se afigurar hipótese que já nasce excluída da possibilidade de tributação por força de comando emanado da Lei Maior, constitui exceção à norma jurídica tributária decorrente de lei.

Antes de se aprofundar o estudo da isenção, passa-se à análise da isenção imprópria.

As isenções impróprias têm palco em situações em que a lei afasta da tributação certas circunstâncias, não para excetuá-las, mas para definir de forma negativa quais os fatos a ela sujeitos ${ }^{184}$. Assim, tal isenção é verificada quando se trata de norma que define ou declara fato que não se integra ao fato gerador, de modo a apenas esclarecer o conteúdo e alcance deste último.

No caso das isenções impróprias, a norma definidora somente explicitará o real alcance da norma tributária, já que o fato por ela previsto jamais estaria configurado no fato típico. Para Sainz de Bujanda ${ }^{185}$, por intermédio das isenções impróprias, evita-se que situações não compreendidas logicamente na estrutura do pressuposto possam, dada a similitude objetiva com estas, originar a crença de que o estão.

Tais normas são, pois, meramente declaratórias e interpretativas de hipótese de não incidência da norma tributária.

As isenções propriamente ditas são distintas das aludidas figuras, porquanto excluem determinados fatos do conjunto de fatos integrantes da norma de incidência tributária e, longe de ser meramente interpretativas, demarcam o âmbito da lei tributária.

A doutrina tradicional ${ }^{186}$, capitaneada por Rubens Gomes de Sousa, defendia que a isenção configuraria um favor legal, a partir da premissa de que haveria a ocorrência do

\footnotetext{
${ }^{184}$ BORGES, José Souto Maior. Op. cit., p. 197.

${ }^{185}$ SAINZ DE BUJANDA, Fernando. Teoría de la exención tributaria: hacienda y derecho. Madrid: Instituto de Estudios Políticos, 1963. v. 3, p. 405.

${ }^{186}$ Em que pese parte da doutrina sustentar que a isenção consiste na dispensa legal de pagar o tributo devido, o presente trabalho posiciona-se no sentido de considerar que o preceito isentivo consubstancia verdadeira
} 
fato gerador, com o subsequente nascimento do vínculo obrigacional, para, em seguida, em virtude da norma isentante, ocorrera dispensa do débito tributário.

Souto Maior Borges ${ }^{187}$, em sua obra Teoria Geral da Isenção Tributária, combate tal concepção, sustentando que a lei "ao selecionar fatos geradores e delimitar o campo abrangido pela hipótese de incidência, institui as isenções, isto é, retira certos fatos ou pessoas, normalmente sujeitos à tributação, do campo de incidência da definição legal do fato gerador". Assim, em face da subtração de elementos do fato gerador, não haveria que se falar em incidência da norma tributária e na respectiva dispensa de pagamento, mas na ocorrência de uma exceção à regra.

Explicita o aludido jurista que o alcance do preceito que tributa é limitado pela norma que isenta, sendo esta, pois, regra limitadora ou modificadora. Segundo ele, tal característica distingue a isenção da imunidade. Isto porque, enquanto esta última préexclui a criação de normas jurídicas impositivas, a primeira subtrai (retira para fora) do campo de incidência da tributação a pessoa ou o bem isento. Em suma: a norma jurídica de isenção equivale à hipótese de não incidência, legalmente qualificada, da norma que prescreve a obrigação tributária. Há, pois, a limitação da validade da norma obrigacional.

Hugo de Brito Machado, em artigo dedicado ao estudo da isenção, imunidade e não incidência, sintetiza as características dos mencionados institutos ${ }^{188}$ :

a) Isenção é exceção feita pela lei à regra jurídica de tributação.

b) Não incidência é a situação em que a regra jurídica de tributação não incide porque não se configura a sua hipótese de incidência. Pode ser: pura e simples, se resulta da clara inocorrência da hipótese de incidência da regra de tributação; ou juridicamente qualificada, se existe regra jurídica expressa dizendo que não se configura, no caso, a hipótese de incidência tributária.

exceção à incidência da norma genérica da tributação, de modo que não ocorrendo a tributação regular, impossível se cogitar em dispensa de pagamento do respectivo tributo. Trilhando um entendimento do qual não se compartilha, aduz Geraldo Ataliba: "Isenção é a dispensa legal do pagamento do tributo devido" (ATALIBA, Geraldo. Natureza jurídica da contribuição de melhoria. São Paulo: RT, 1964. p. 140). Já Ives Gandra da Silva Martins, ao prefaciar a obra de Aurélio Pitanga Seixas Filho, Teoria e prática das isenções tributárias. Rio de Janeiro: Forense, 1989, assim se manifestou: "Entendo que a isenção é a dispensa legal do pagamento do tributo, cuja obrigação nasce a partir do fato gerador, mas excluído está o surgimento do crédito tributário correspondente". Para Rubens Gomes de Sousa, "Isenção é o favor fiscal concedido por lei, que consiste em dispensar o pagamento de um tributo devido. É importante fixar bem as diferenças entre não incidência e isenção: tratando-se de não incidência, não é devido o tributo porque não chega a surgir a própria obrigação tributária; ao contrário, na isenção o tributo é devido, porque existe a obrigação, mas a lei dispensa o seu pagamento" (SOUSA, Rubens Gomes de. Compêndio de Legislação Tributária. Ed. póstuma. São Paulo: Resenha Tributária, 1975. p. 97).

${ }^{187}$ BORGES, José Souto Maior. Op. cit., p. 171.

${ }^{188}$ MACHADO, Hugo de Brito. Não incidência, imunidades e isenções do ICMS. In: BRITO, Edvaldo Pereira (Coord.). Doutrinas essenciais de direito tributário. São Paulo: RT, 2011. v. 2, p. 547. 
c) Imunidade é o obstáculo criado por uma norma da Constituição, que impede a incidência de lei ordinária de tributação.

Por seu turno, o professor Paulo de Barros Carvalho ${ }^{189}$ assevera que a norma de isenção opera sobre um ou mais elementos da regra matriz de incidência tributária, de modo a retirar-lhe parcialmente a sua abrangência:

Guardando a sua autonomia normativa, a regra de isenção investe contra um ou mais critérios da norma-padrão de incidência, mutilando-os parcialmente. É óbvio que não pode haver supressão total do critério, porquanto equivaleria a destruir a regra matriz, inutilizando-a como norma válida no sistema. $O$ que o preceito da isenção faz é subtrair parcela do campo de abrangência do critério do antecedente ou do consequente.

Nessa linha de raciocínio, sustenta Paulo de Barros Carvalho ${ }^{190}$ que a norma isentiva e a de não incidência possuem a mesma natureza jurídica, porquanto em ambos os casos se verifica a mutilação de um dos critérios da hipótese da regra matriz de incidência tributária (material, espacial ou temporal), excluindo-se assim determinados fatos da incidência da norma.

Em face do até aqui exposto, especialmente quanto à evolução da concepção do instituto da isenção, observa-se que, quando o artigo 175 do Código Tributário Nacional inclui a isenção no rol das hipóteses de exclusão do crédito tributário, esta hipótese deve ser concebida como referida à própria exclusão da obrigação, pois é inconcebível haver crédito sem a correlata obrigação.

Nessa altura, cabe abordar a polêmica figura da isenção parcial. Na isenção parcial ocorre o fato gerador e, consequentemente, surge a obrigação tributária, porém, em quantidade inferior à regularmente devida ${ }^{191}$.

Adverte o professor Souto Maior Borges ${ }^{192}$ que a expressão mais apropriada para ser conferida à isenção parcial seria redução tributária, haja vista que, ao contrário do que se verifica na hipótese de isenção, o fato gerador da obrigação tributária se produziria.

\footnotetext{
${ }^{189}$ CARVALHO, Paulo de Barros. Op. cit., p. 490.

${ }^{190}$ Id. Ibid., p. 116.

${ }^{191}$ BORGES, José Souto Maior. Op. cit., p. 192: “as isenções totais excluem o nascimento da obrigação tributária, enquanto, nas isenções parciais, surge o fato gerador da tributação, constituindo-se, portanto, a obrigação tributária, embora o quantum do débito seja inferior ao que normalmente seria devido senão tivesse sido estabelecido preceito isentivo".

${ }^{192}$ BORGES, José Souto Maior. Op. cit., p. 280.
} 
Com fulcro em doutrina espanhola, sustenta o aludido autor ${ }^{193}$ que a isenção parcial se aperfeiçoa com técnicas desagravatórias que afetam a quantificação da prestação, a exemplo da redução da base de cálculo. Assim, o "legislador pode matizar as consequências da realização do fato tributável, configurando a obrigação tributária surgida deles em montante inferior ao ordinariamente exigível".

De sua parte, Pontes de Miranda ${ }^{194}$ assevera que as isenções parciais promovem a dedução do percentual do imposto ou do imposto fixo, consubstanciando minorações isentivas. Assim, as isenções totais excluem previamente a imposição, hipótese em que o imposto não recairá no objeto ou no negócio jurídico a que se reporta a regra jurídica de isenção.

Por essa linha de raciocínio, no caso da isenção parcial, a ocorrência do fato gerador irá desencadear obrigação tributária em montante inferior ao regularmente devido.

Tal entendimento, entretanto, não é adotado por parte da doutrina ${ }^{195}$ que defende a inexistência de isenções parciais, por considerar que o instituto da isenção afasta a ocorrência do fato gerador, não podendo as reduções de base de cálculo e alíquota ser equiparadas a tal instituto. Sacha Calmon ${ }^{196}$ assim aborda a questão:

Ocorre, no entanto, que à luz da teoria da norma jurídica tributária, a denominação de isenção parcial para o fenômeno da redução parcial do imposto a pagar, através de minorações diretas da base de cálculo e alíquotas, afigura-se incorreta e inaceitável.

A isenção ou é total ou não é, porque a sua essentialia consiste em ser modo obstativo ao nascimento da obrigação. Isenção é o contrário de incidência. As reduções, ao invés, pressupõem a incidência e a existência do dever tributário instaurado com a realização do fato jurígeno previsto na hipótese de incidência da norma de tributação. As reduções são diminuições monetárias no quantum da obrigação, via base de cálculo rebaixada ou alíquota reduzida.

\footnotetext{
${ }^{193}$ Id. Ibid., p. 260.

${ }^{194}$ PONTES DE MIRANDA, Francisco Cavalcanti. Op. cit., t. 3, p. 90.

${ }^{195}$ Luciano Amaro sustenta inexistir a isenção parcial e afirma que: "Fala-se, ainda, por oposição às isenções 'totais', em isenções 'parciais', querendo-se, com essa qualificação, expressar as situações em que a lei reduz o gravame fiscal sobre certa situação. Neste caso, talvez não se deva designar a situação como isenta. O fato é gerador; o que se dá é que, à vista de certa especificidade da situação, a alíquota (ou a base de cálculo) é menor (assim como poderia ser maior), quando comparada à da situação similar em que a referida especificidade não se faz presente" (AMARO, Luciano da Silva. Op. cit., p. 281).

O Professor Paulo de Barros Carvalho também afasta a figura da isenção parcial, como se verifica do trecho reproduzido: "Não confundamos subtração do campo de abrangência do critério da hipótese ou da consequência com mera redução da base de cálculo ou da alíquota sem anulá-las. A diminuição que se processa no critério quantitativo, mas que não conduz ao desaparecimento do objeto, não é isenção, traduzindo singela providência modificativa que reduz o quantum de tributo que deve ser pago" (Op. cit., p. 488).

${ }^{196}$ COÊLHO, Sacha Calmon Navarro. Curso de direito tributário brasileiro. 9. ed. Rio de Janeiro: Forense, 2007.
} 
Diante do exposto, resta claro que, se for considerado que as normas isentivas extirpam da estrutura lógica do fato gerador determinado fato específico, a quedar afastado da tributação ${ }^{197}$, a figura da isenção parcial, se utilizado o rigor terminológico conceitual, aí não se amoldaria, por óbvio. Diante disso, caberia ao legislador valer-se de técnicas desonerativas, a exemplo da redução de base de cálculo e alíquota para diminuir o montante a ser tributado.

Por outra parte, a análise do efeito do que ocorre com a parcela que foi excluída da tributação leva à constatação de que houve uma isenção de tal parcela, pelo que seria possível adotar a denominação de isenção parcial.

Nesta toada, verifica-se que, no caso da isenção parcial, a ocorrência do fato gerador irá desencadear obrigação tributária em montante inferior ao regularmente devido.

A seguir, demonstrar-se-á que o legislador poderá valer-se da isenção, seja com o intuito de adequar a tributação ao princípio da capacidade contributiva, seja com o objetivo de incentivar social ou economicamente determinada atividade. Trata-se, pois, de hipótese de isenção fiscal e extrafiscal, respectivamente.

Assim, no caso da isenção fiscal, o fato excluído revela carência de capacidade contributiva, razão por que o legislador promoverá uma adequação ou compatibilização do fato gerador com a situação especial da pessoa vinculada a este ${ }^{198}$. Há uma exclusão lastreada no caráter negativo da norma (limitações de tributar), verdadeiro ajuste ao sistema tributário.

O exemplo clássico consiste na isenção dos mínimos isentos, tal como ocorre no Imposto de Renda Pessoa Física - IRPJ, em que os rendimentos inferiores a um teto mínimo disposto pela legislação são afastados da tributação.

Por seu turno, quando se pretender fomentar determinada atividade econômica, que merece ser particularizada, mas que não é carente de capacidade contributiva, o legislador irá impor encargos e condições para justificar a isenção. São, exatamente, tais condições que irão especificar o regime jurídico excepcional da isenção extrafiscal.

\footnotetext{
${ }^{197}$ SEIXAS FILHO, Aurélio Pitanga. Op. cit., p. 22.

${ }^{198}$ Id. Ibid., p. 23.
} 
A caracterização precisa das isenções fiscais e extrafiscais foi elaborada por Aurélio Pitanga Seixas Filho, consoante se verifica do trecho abaixo reproduzido da sua obra Teoria e Prática das Isenções Tributárias ${ }^{199}$ :

Como a isenção fiscal (exclusão) é uma forma de retificar a abrangência do fato gerador para adequá-lo à capacidade contributiva da "pessoa excluída", a situação jurídica desta pessoa, no momento da ocorrência do fato gerador, independe do cumprimento do requisito ou encargo legal para ficar isenta ou excluída da obrigação tributária, o que é uma simples decorrência da sua tipicidade legal especial, devendo ser como tal interpretada.

Já nas isenções extrafiscais (incentivos), a situação jurídica da pessoa favorecida depende do cumprimento prévio de encargos legais para obter o direito à isenção no momento da ocorrência do fato gerador, sendo também frequente que a lei venha a exigir um determinado comportamento por um período certo de tempo após a ocorrência do fato gerador, sob pena de resolver a isenção concedida.

Nesta perspectiva, e considerando o escopo deste estudo, ter-se-á como foco o estudo das isenções concedidas no contexto da extrafiscalidade, pelo que se passa a analisá-las.

Exemplo clássico de isenção extrafiscal é aquela concedida a indústria nova, geralmente instalada em região menos desenvolvida, condicionada à formalização de determinado número de vínculos empregatícios e por prazo certo.

A isenção serve, neste caso, como estímulo fiscal a empresas consideradas de interesse ao Estado, sendo utilizada a serviço de política de industrialização e disponibilizada para todo o grupo de contribuintes que se encontra nas mesmas condições postas pela regra isentiva. Acerca da compatibilidade de tais isenções ao Sistema Constitucional Tributário, ressalte-se o preconizado por José Souto Maior Borges ${ }^{200}$ :

\begin{abstract}
A isenção, regra de direito excepcional frente ao princípio da generalidade da obrigação tributária, há de ser concedida por motivos ponderáveis de ordem econômico-social, razões extrafiscais relevantes, ou importará em violação daquele princípio. Deve, por isso, beneficiar a toda a classe de indústria que esteja em igualdade de condições e não somente a um contribuinte isolado.
\end{abstract}

Com efeito, busca-se fomentar a indústria nova quando o retorno ao investimento realizado é incerto, seja em face das condições precárias da região em que esta se instalou

\footnotetext{
${ }^{199}$ SEIXAS FILHO, Aurélio Pitanga. Op. cit., p. 23.

${ }^{200}$ BORGES, José Souto Maior. Op. cit., p. 75.
} 
(em termos logísticos, de mão de obra especializada, mercado consumidor etc.), seja por força de o resultado da sua produção melhor atender ao bem comum, embora ainda não tenha mercado consumidor estável (a exemplo de produtos "verdes", como o papel reciclado que encontra resistência por ainda não possuir as mesmas características do papel tradicional ou produtos de maior eficiência energética ou hídrica, pouco divulgados e/ou mais caros por não serem, em alguns casos, produzidos em grande escala).

Tais estímulos são concedidos, em regra, por tempo determinado, já que se presume que, "esgotado o ciclo inicial de implantação e organização da indústria, tenha ela aptidão para suportar o ônus tributário ${ }^{201 ، ،}$.

Durante o prazo em que o Estado se compromete a estimular o empreendimento novo, todavia, não é possível haver a irrestrita supressão ou redução do mencionado estímulo. Tal garantia é preconizada pelo artigo 178 do Código Tributário Nacional, segundo o qual o incentivo fiscal concedido por prazo certo e em determinadas condições não pode ser revogado nem modificado.

Tal disposição busca conferir segurança jurídica aos contribuintes; estes, valendo-se de tratamento fiscal favorecido, realizam investimento que não fariam em circunstâncias normais de tributação. De tal modo, uma vez concedida a isenção (atendidos os requisitos formais e materiais desta), o contribuinte não pode ter o regime excepcional desconstituído abruptamente. Adquire-se, pois, direito ao gozo da isenção tributária pelo prazo e condições definidos, ainda que a lei que tenha criado o incentivo seja revogada.

Nesta linha, foi cunhada a súmula número 544 do Supremo Tribunal Federal, segundo a qual "isenções tributárias concedidas, sob condição onerosa, não podem ser livremente suprimidas".

Sobre a revogação da isenção em situações que não mais se justificam e acerca da impossibilidade da sua supressão arbitrária, aduziu Aliomar Baleeiro ${ }^{202}$ :

[...] em princípio, a regra deve ser a revogabilidade ou a redutibilidade da isenção em qualquer tempo em que o Estado entenda que ela já não corresponde ao interesse público do qual promanou. Mas há exceções, quando a isenção, pelas condições de sua outorga, conduziu o contribuinte a uma atividade que ele não empreenderia se estivesse sujeito aos tributos da época. Nesses casos, a revogabilidade, total ou parcial, seria um ludíbrio à boa-fé dos que confiaram nos incentivos acenados pelo Estado.

${ }^{201}$ BORGES, José Souto Maior. Op. cit., p. 76.

${ }^{202}$ BALEEIRO, Aliomar. Direito tributário brasileiro. 17. ed. Rio de Janeiro: Forense, 1999. p. 605. 
Conclui-se, portanto, que a norma isentiva é passível de ser revogada a qualquer tempo, especialmente se for constatado que os motivos que a fundamentaram não mais persistem. Caso contrário, tornar-se-ia injustificada a manutenção de comando excepcional, abalando, assim, a sua idoneidade. Todavia, ainda que a lei em abstrato seja revogada, enquanto vigente o contrato, por prazo certo, com base em tal diploma legal, a fruição do incentivo deve ser garantida ao contribuinte até o seu termo final ${ }^{203}$.

O princípio da segurança jurídica e da confiança é vetor de tamanho relevo num Estado Democrático de Direito, que, em determinadas situações, ainda que a isenção concedida contenha um vício formal, é possível preservar os efeitos, desde que, numa ponderação concreta, a segurança jurídica se sobreponha à legalidade, em virtude de o incentivo concedido estar a concretizar valores abarcados pelo conceito de interesse público, cuja efetivação seria imposta ao Estado ${ }^{204}$.

Deve, portanto, haver a ponderação dos interesses, valores e bens que permeiam a situação concreta em que se pretende findar a isenção concedida, visando à preservação, na maior medida, do princípio da confiança do contribuinte ${ }^{205}$.

Por seu turno, situações há em que não se opera a revogação ou a redução da norma isentiva; entretanto, o conteúdo econômico do incentivo pode vir a ser esvaziado, por modificação da própria estrutura da imposição tributária, hipótese em que o pacto entre o Estado e o contribuinte é mantido, porém são verificados prejuízos concretos.

Exemplo que se verifica é quando há a concessão de isenção de ICMS a empresa nova que irá ser implantada em região longínqua e pouco desenvolvida em termos econômicos e sociais. Assim, o ente federado se abstém de cobrar o tributo que lhe seria

\footnotetext{
${ }^{203}$ No dizer de Aurélio Pitanga Seixas Filho, "não se deve confundir o prazo de fruição do favor fiscal já contratualmente adquirido com o prazo de vigência da norma isencional, pois a situação jurídica subjetiva é que é imodificável, e não a norma isentiva" (Op. cit., p. 165).

${ }^{204}$ ÁVILA, Humberto. Benefícios fiscais inválidos e a legítima expectativa do contribuinte. Revista Eletrônica de Direito Administrativo Econômico, Salvador, Instituto de Direito Público da Bahia, n. 4, p. 12, nov.-dez. 2005; jan. 2006. Disponível em:<http://direitodoestado.com.br>. Acesso em: 10 out. 2011.

${ }^{205}$ Humberto Ávila assim concluiu acerca da extensão do poder de revogação dos incentivos fiscais acometidos por invalidades formais: "O poder de revisão de benefícios fiscais sobre ser limitado substancialmente pelos direitos fundamentais só pode ser exercido por meio de procedimento que permita uma justa harmonização do dever de observar a forma com o poder de respeitar a confiança. A mera desconsideração, por irregularidades formais, das relações formadas em função de comportamentos anteriores do próprio Poder Público é incompatível com os princípios fundamentais do Estado de Direito. O valor de obediência à forma, antes mesmo de prevalecer sobre o valor da confiança, deve ser com ele harmonizado por meio de procedimentos que permitam a ponderação de todos os interesses em conflito" (ÁVILA, Humberto. Op. cit., p. 16).
} 
devido, experimentando o contribuinte investidor vantagem em instalar-se no referido Estado em relação às outras empresas contribuintes que estejam instaladas em outros Estados e recolhem o tributo integralmente.

Ocorre que, se houver, por hipótese, redução do tributo de forma uniforme por todos os entes federados, em termos competitivos, não haverá mais tanta vantagem, uma vez que a tributação abrandada, em termos gerais, não trará o mesmo diferencial anteriormente obtido, pelo que os custos adicionais demandados por estar sediado em Estado longínquo (frete, formação de mão de obra, desenvolvimento de mercado consumidor) suplantarão o estímulo anteriormente pactuado e visualizado.

Constata-se, dessa forma, que mesmo que se mantenha o arcabouço legal específico da isenção, alterações externas (mudanças de alíquotas interestaduais por força de Resolução do Senado, por exemplo) possivelmente abalarão a expectativa do contribuinte incentivado, situação que poderá legitimar novo estímulo, de modo a garantir o cenário anteriormente sinalizado, sob pena de todos os investimentos e esforços empreendidos pelo particular serem convertidos em graves danos.

\subsubsection{Crédito presumido}

Crédito presumido é uma técnica legislativa financeira para a adequação do montante a ser tributado ${ }^{206}$.

Irá interessar mais diretamente ao presente estudo quando referida técnica tiver seus delineamentos voltados à efetiva redução ou anulação do tributo a pagar ${ }^{207}$. Isto é, na hipótese em que o seu formato promove redução do imposto a pagar mediante o oferecimento de um valor adicional agregado ao montante de crédito apurado pelo contribuinte ${ }^{208}$.

\footnotetext{
${ }^{206}$ CATÃO, Marcos André Vinhas. Op. cit., p. 71.

${ }^{207}$ Uma das técnicas que o legislador pode manejar, com base na figura do crédito presumido, é utilizá-lo na substituição da apuração normal de determinado tributo não cumulativo. Assim, por exemplo, em se tratando da legislação de ICMS, a sua aplicação pode ser efetivada mediante a substituição de todos os créditos, passíveis de ser apropriados em virtude da entrada de mercadorias ou bem, por um determinado percentual relativo ao imposto debitado no momento das saídas de mercadorias ou prestações de serviço. Em tal hipótese, a técnica em comento poderá vir a implicar a redução do tributo a pagar, porém o que realmente se verifica é a simplificação da apuração do valor devido, o que, como se viu, não se confunde com a função indutora dos incentivos fiscais.

${ }^{208}$ CATÃO, Marcos André Vinhas. Op. cit., p. 72.
} 
Noutros dizeres, adiciona-se determinada quantia, que pode possuir ou não correlação com o crédito tributário efetivo (um percentual das aquisições ou um montante fixo), ao total pago ou destacado nas operações anteriores ${ }^{209}$.

Para Kiyoshi Harada ${ }^{210}$, o crédito presumido consubstancia "valor estimativo, fixado pelo Poder Público a favor do contribuinte de imposto de natureza nãocumulativa em função dos insumos, combinação dos fatores de produção (matérias-primas, materiais secundários consumidos no processo de industrialização, energia consumida etc.) que entram na produção de certos bens ou serviços".

Sob tal prisma, os créditos presumidos irão consubstanciar créditos fíctícios lançados na escrita fiscal e que irão resultar em redução ou anulação da imposição que seria devida caso não houvesse a adição de tal montante.

Para atraírem investimentos, os Estados da Federação costumam ofertar crédito presumido de ICMS a indústrias que pretendem se instalar ou ampliar o seu negócio no território do respectivo ente federado.

Nesta toada, os mencionados créditos presumidos de ICMS assemelham-se, sob o aspecto econômico, a uma subvenção para investimento, haja vista que constituem repasse de crédito ao particular, visando ao fomento de atividade econômica.

Importante observar, todavia, que referido crédito funcionará como redutor de custos relacionados à tributação, razão pela qual a jurisprudência do Superior Tribunal de Justiça $^{211}$ tem afastado a sua qualificação como uma receita, nos seguintes termos: “o crédito presumido do ICMS configura incentivo voltado à redução de custos, com intuito de proporcionar maior competitividade no mercado para as empresas de um determinado Estado-membro, e, portanto, não assume a natureza de receita ou faturamento”.

Para a Receita Federal do Brasil, sempre que este crédito presumido se caracterizar como uma subvenção para investimento, não será somado para o cálculo do IR e da CSLL, nem integrará a base de cálculo da Contribuição ao PIS e da COFINS, regidos pelo regime da não cumulatividade ${ }^{212}$.

\footnotetext{
${ }^{209}$ CATÃO, Marcos André Vinhas. Op. cit., p. 72.

210 HARADA, Kiyoshi. Responsabilidade fiscal: Lei complementar n. 101/2000 comentada e legislação correlata anotada. São Paulo: Juarez de Oliveira, 2002. p. 63.

${ }^{211}$ AgRg no Recurso Especial n. ${ }^{\circ} 1.165 .316 / \mathrm{SC}$ (2009/0220288-7).

212 Processo de Consulta n. ${ }^{\circ}$ 38/2012

Assunto: Imposto sobre a Renda de Pessoa Jurídica - IRPJ.

Ementa: Crédito presumido de ICMS. Caracterização como subvenção corrente. Sujeição à tributação.
} 
Trata-se, assim, de importante instrumento de que pode se valer o ente político para fomentar investimentos que visam à adaptação de indústria a padrões mais sustentáveis, em face da redução de custo verificada.

\subsubsection{Diferimento}

É comum que os Estados incentivem determinados setores mediante o diferimento do tributo devido, hipótese em que o critério temporal para o cumprimento da obrigação tributária é alterado.

Deveras, o objetivo do diferimento é adiar a extinção do crédito tributário (pagamento, compensação etc.) para momento posterior. O clássico exemplo seria o do

Os créditos presumidos de ICMS que não sejam caracterizados como subvenção para investimento são qualificados como receita, na espécie subvenção corrente para custeio ou operação, devendo ser computados na apuração do resultado do exercício, utilizado na determinação do lucro real.

Dispositivos Legais: Lei n. ${ }^{\circ}$ 4.506, de 1964, art. 44, inciso IV; Decreto-lei n. ${ }^{\circ} 1.598$, de 1977, art. 38, §2. , com redação dada pelo Decreto-lei n. ${ }^{\circ} 1.730$, de 1979, art. 1. ${ }^{\circ}$, inciso VIII; Decreto n. ${ }^{\circ}$ 3.000, de 1999 (RIR/99), art. 392, inciso I, e art. 443; PN CST n. ${ }^{\circ} 112$, de 1979.

Assunto: Contribuição Social sobre o Lucro Líquido - CSLL.

Crédito presumido de ICMS. Caracterização como subvenção corrente. Sujeição à tributação.

Os créditos presumidos de ICMS que não sejam caracterizados como subvenção para investimento são qualificados como receita, na espécie subvenção corrente para custeio ou operação, devendo ser computados na apuração do resultado do exercício, utilizado na determinação da base de cálculo da Contribuição Social sobre o Lucro Líquido (CSLL).

Dispositivos Legais: Lei n. ${ }^{\circ} 4.506$, de 1964, art. 44, inciso IV; Decreto-lei n. ${ }^{\circ} 1.598$, de 1977, art. 38, § 2. ${ }^{\circ}$, com redação dada pelo Decreto-lei n. ${ }^{\circ} 1.730$, de 1979, art. 1. ${ }^{\circ}$, inciso VIII; Lei n. ${ }^{\circ} 8.981$, de 1195, art. 57; Decreto n..$^{\circ}$ 3.000, de 1999 (RIR/99), art. 392, inciso I, e art. 443; PN CST n. ${ }^{\circ} 112$, de 1979.

Processo de Consulta n. ${ }^{\circ}$ 57/2012

Assunto: Contribuição para o Financiamento da Seguridade Social - Cofins.

Ementa: Crédito presumido. Base de cálculo. Inclusão.

O crédito presumido de ICMS, estabelecido pelo art. 629 do RICMS (Decreto n. ${ }^{\circ} 1.980$, de 2007) do Paraná, concedido quando da importação pelos portos e aeroportos desse Estado, integra a base de cálculo da Cofins apurada pela sistemática não cumulativa.

Dispositivos Legais: Art. 150 da Constituição Federal; Art. 97 da Lei n. ${ }^{\circ}$ Lei n. ${ }^{\circ}$ 5.172, de 1966 (CTN); Arts. $2 .^{\circ}$ e $3 .^{\circ}$ da Lei n. ${ }^{\circ} 9.178$, de 1998; Art. $1 .^{\circ}$ da Lei n. ${ }^{\circ} 10.833$, de 2003; Inciso XII do art. 79 da Lei n. ${ }^{\circ}$ 11.941, de 2009; Arts. 392 e 443 do Regulamento aprovado pelo Decreto n. ${ }^{\circ} 3.000$, de 1999 (RIR/99); e Parecer Normativo CST n. ${ }^{\circ} 112$, de 1978.

Assunto: Contribuição para o PIS/Pasep. Crédito presumido. Base de cálculo. Inclusão.

O crédito presumido de ICMS, estabelecido pelo art. 629 do RICMS (Decreto n. ${ }^{\circ} 1.980$, de 2007) do Paraná, concedido quando da importação pelos portos e aeroportos desse Estado, integra a base de cálculo da Contribuição para o PIS apurada pela sistemática não cumulativa.

Dispositivos Legais: Art. 150 da Constituição Federal; Art. 97 da Lei n. ${ }^{\circ}$ Lei n. ${ }^{\circ}$ 5.172, de 1966 (CTN); Arts. $2 .^{\circ}$ e $3 .^{\circ}$ da Lei n. ${ }^{\circ} 9.178$, de 1998; Art. $1 .^{\circ}$ da Lei n. ${ }^{\circ} 10.637$, de 2002; Inciso XII do art. 79 da Lei n. ${ }^{\circ}$ 11.941, de 2009; Arts. 392 e 443 do Regulamento aprovado pelo Decreto n. ${ }^{\circ} 3.000$, de 1999 (RIR/99); e Parecer Normativo CST n. ${ }^{\circ} 112$, de 1978. 
imposto plurifásico e não cumulativo, em que a obrigação de recolher o imposto é transferida para momento posterior àquele em que seria ordinariamente devido. Tal adiamento visa a conferir tratamento favorecido, por exemplo, a certo setor produtivo, destinando o cumprimento da obrigação tributária para outro setor que, em tese, estaria dotado de melhores condições de suportar o encargo.

A rigor, poder-se-ia sustentar que, enquanto a isenção afasta ou reduz o pagamento de um imposto, o diferimento livra uma operação do pagamento da obrigação tributária, onerando a operação posterior (a etapa subsequente) $)^{213}$.

Rubens Gomes de Sousa ${ }^{214}$, ao analisar o diferimento concedido pela legislação de IPI a um produto utilizado na fabricação de outro produto pelo mesmo fabricante, equipara tal instituto a uma "suspensão" e defende que, neste caso, por meio do "diferimento da incidência”, o valor do produto utilizado na industrialização de outro irá agregar-se ao valor deste último, sendo tributado como parte integrante do produto novo quando da sua saída. Em tal hipótese, restaria caracterizado que a utilização do primeiro produto configura uma etapa intermediária da produção.

Ao analisar o ICMS, Sylvio César Afonso ${ }^{215}$ aduz que o diferimento é "uma postergação do momento do recolhimento do tributo (o oposto, portanto, da forma tradicional), que pode vir a se concretizar em longínqua etapa de comercialização e aplicável com grande ênfase a produtos agropecuários, resíduos e sucatas, facilitando com isto, na essência do ICMS, a agregação de valores para uma futura tributação”.

Verifica-se, pois, que tal instituto é bem apropriado quando se pretende promover e fortalecer determinada cadeia produtiva, afastando-se o clássico sistema de débito e crédito dos tributos não cumulativos, em suas diversas fases de produção, para que a exigência do valor total devido recaia apenas na etapa final desta.

Quanto à equiparação entre diferimento e suspensão, esta é também acolhida por Marcos André Vinhas Catão, para quem não há “qualquer traço jurídico ou finalidade relevante pelo qual se possam distinguir as duas figuras, ou pelo simples fato de assim procederem algumas legislações fiscais".

\footnotetext{
${ }^{213}$ Todavia, em determinadas situações, o diferimento muito se assemelha à figura da isenção condicionada, visto que as normas veiculadoras do diferimento impõem condições cujo cumprimento pode vir a implicar verdadeira isenção definitiva do tributo.

${ }^{214}$ SOUSA, Rubens Gomes. IPI e as vendas de ativo fixo. In: BRITO, Edvaldo Pereira (Coord.). Doutrinas essenciais de direito tributário. São Paulo: RT, 2011. v. 3, p. 951.

${ }^{215}$ BRITO, Edvaldo Pereira (Coord.). Doutrinas essenciais de direito tributário. São Paulo: RT, 2011. v. 4, p. 941.
} 
Na linguagem do Supremo Tribunal Federal (RE 98.568-9-SP, DJ 07.10.1983), lastreada em doutrina de Ives Gandra Martins ${ }^{216}$, haveria a postergação da incidência. Ressalte-se o ementário 1.311-4, abaixo transcrito:

ICM. Diferimento. Leite in natura. Convênio ICM 7/77. O diferimento da incidência do ICM não ofende o princípio constitucional da não cumulatividade do tributo. Precedentes da Corte. Dissídio superado (Súm. 286). Recurso extraordinário não conhecido.

Nota-se, assim, que em relação aos produtos verdes, cuja cadeia pode o ente político pretender fortalecer, afigura-se adequado o manejo do instituto em tela, possibilitando que a carga tributária só incida, de fato, em etapa na qual se encontre contribuinte com maiores condições de arcar com tal ônus.

Por fim, cumpre registrar que o diferimento ora em pauta em nada se assemelha ao diferimento do direito de o contribuinte compensar os créditos, por meio de apropriações parciais mensais, no caso de bens do ativo, de que trata, por exemplo, a LC 102/2000, que deu nova redação ao art. 20, § 5. ${ }^{\circ}$, da LC 87/1996.

\subsubsection{Redução de base de cálculo}

O incentivo fiscal também poderá ser efetivado por meio da figura da redução da base de cálculo. Por meio do referido instrumento, o ente tributante autoriza que, em certas situações, o contribuinte calcule o tributo sobre um valor inferior àquele que, em tese, seria o devido.

Neste contexto, o tratamento benéfico é conferido por força da modificação de um dos elementos quantitativos da hipótese de incidência, que irá diminuir o quantum devido a título do tributo.

Tendo em vista que tanto a redução da base de cálculo quanto a isenção implicam a desoneração quanto ao recolhimento do tributo, a redução da base de cálculo pode ser concebida como hipótese de isenção parcial.

\footnotetext{
${ }^{216}$ MARTINS, Ives Gandra da Silva; PAVAN, Claudia Fonseca Morato. ICMS. Substituição tributária. Transferência de créditos autorizada por portaria. Inconstitucionalidade. Nulidade ex tunc. consequências. Revista Tributária e de Finanças Públicas, São Paulo, v. 45, p. 257, jul. 2002. DTR\2002\394.
} 
Sob o aspecto jurídico, a concepção de que a isenção constitui uma regra de exceção ao fato gerador, obstando a constituição da obrigação tributária em si, e que a redução da base de cálculo somente produz efeitos em relação a um dos aspectos quantitativos da hipótese de incidência (situado na consequência da norma), faz com que muitas vozes afastem essa classificação, consoante já descrito acima ${ }^{217}$.

Voltando-se para a Carta Política de 1988, verifica-se que, em seu art. 150, $\S 6 .^{\circ}$, o constituinte, ao dispor que o subsídio, isenção, redução de base de cálculo, anistia e remissão devem ser instituídos por lei específica, designou de forma diferenciada cada um dos referidos institutos. Com lastro em tal preceito, a categorização da redução de base de cálculo como modalidade de isenção parcial vem sendo contestada. Vittorio Cassone ${ }^{218}$ assevera que promover equiparações nesse sentido seria hipótese de interpretação absurda:

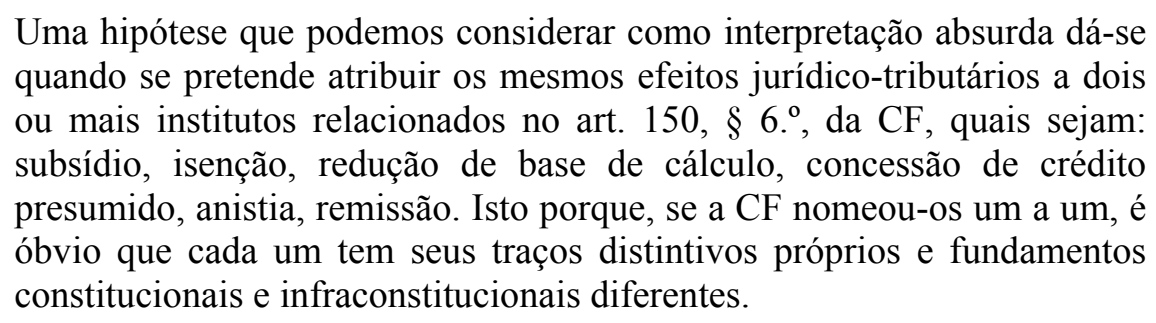

Uma hipótese que podemos considerar como interpretação absurda dá-se quando se pretende atribuir os mesmos efeitos jurídico-tributários a dois ou mais institutos relacionados no art. $150, \S 66^{\circ}$, da $\mathrm{CF}$, quais sejam: subsídio, isenção, redução de base de cálculo, concessão de crédito presumido, anistia, remissão. Isto porque, se a CF nomeou-os um a um, é constitucionais e infraconstitucionais diferentes.

A possibilidade de equiparação da redução da base de cálculo à isenção parcial, longe de afigurar-se mero preciosismo acadêmico, é imprescindível para o adequado manejo do instituto em questão, haja vista que a Constituição Federal de 1988, ao versar sobre o ICMS, houve por bem afastar o creditamento integral do imposto que haja incidido na operação anterior, quando as operações subsequentes forem objeto da isenção e da não incidência, para as quais expressamente previu o estorno de créditos.

Deveras, a Carta Política autorizou o creditamento irrestrito por parte dos contribuintes quanto ao ICMS cobrado em operações ou prestações anteriores pelo mesmo ou por outro Estado da Federação, em prestígio ao primado da não cumulatividade. Todavia, ressalvou o direito ao creditamento do imposto quando as operações ou prestações anteriores forem isentas ou não tributadas. É o que se depreende do inciso II do $\S 2 .^{\circ}$ do art. 155 da Carta Magna:

\footnotetext{
${ }^{217}$ No dizer de Sacha Calmon, "as reduções de base de cálculo e de alíquota não são isenções, nem mesmo parciais. São reduções do quantum debeatur e, portanto, pressupõem a ocorrência do fato gerador da obrigação. Atuam na consequência da norma de tributação. A diversidade é material" (COÊLHO, Sacha Calmon Navarro. Op. cit., p. 876).

${ }^{218}$ CASSONE, Vittorio. Interpretação no direito tributário: teoria e prática. São Paulo: Atlas, 2004.
} 
Art. 155. Compete aos Estados e ao Distrito Federal instituir impostos sobre:

\section{$[\ldots]$}

II - operações relativas à circulação de mercadorias

§2. ${ }^{\circ}$. O imposto previsto no inciso II atenderá ao seguinte:

I - será não cumulativo, compensando-se o que for devido em cada operação relativa à circulação de mercadorias ou prestação de serviços com o montante cobrado nas anteriores pelo mesmo ou outro Estado ou pelo Distrito Federal.

II - a isenção ou não incidência, salvo determinação em contrário da legislação:

a) não implicará crédito para compensação com o montante devido nas operações ou prestações seguintes;

b) acarretará anulação do crédito relativo às operações anteriores;

Considerando que, no caso do ICMS, as duas exceções à aplicação do princípio da não cumulatividade estão preconizadas no texto acima reproduzido e se reportam a hipótese de isenção e de não incidência, o cerceamento do creditamento integral do imposto que houver incidido na operação anterior, quando as operações subsequentes são objeto de redução de base de cálculo, é considerado inconstitucional para aqueles que descartam a sua equiparação a uma isenção parcial.

Noutros termos, o entendimento de que a redução da base de cálculo é figura desonerativa distinta da isenção (parcial) afasta a necessidade de o contribuinte estornar proporcionalmente o crédito de ICMS nos casos em que a operação é beneficiada pela redução de sua base de cálculo.

Por um período, ficou assentado no Supremo Tribunal Federal o entendimento no sentido de que as limitações legais ao direito ao creditamento do ICMS somente poderiam ser efetivadas em se tratando de hipótese de isenção e de não incidência, razão pela qual era lícito ao contribuinte aproveitar integralmente os créditos correspondentes às operações anteriores.

Ao interpretar a questão da classificação da redução da base de cálculo como hipótese de isenção parcial, o ministro Marco Aurélio assim se posicionou ${ }^{219}$ :

\footnotetext{
${ }^{219}$ STF, Recurso Ordinário em Mandado de Segurança n. ${ }^{\circ}$ 21.514, Segunda Turma do STF, Rel. Min. Marco Aurélio, j. 27.04.1993. $\quad$ Disponível em: $<$ http://www.stf.jus.br/portal/jurisprudencia/listarJurisprudencia.asp?s1=\%28RMS\%24\%2ESCLA\%2E+E+ 21514\%2ENUME\%2E\%29+OU+\%28RMS\%2EACMS\%2E+ADJ2+21514\%2EACMS\%2E\%29\&base=ba seAcordaos>. Acesso em: 6 jul. 2012.
} 
Sempre tenho presente a premissa de que o Direito é ciência e, como tal, possui institutos, expressões e vocábulos com sentido próprio, havendo de se presumir que o legislador, especialmente o constituinte, haja atuado com técnica, atentando para o fato de que o esmero da linguagem é essencial à revelação do sentido correto da disposição normativa.

Em suma, de acordo com as regras hermenêuticas sedimentadas no Direito brasileiro, o conceito de isenção não pode ser elastecido de modo a abarcar hipóteses de redução de base de cálculo.

Conclusivamente, entendemos, pelas razões acima expostas, que a redução da base de cálculo em nada se confunde com a isenção, não constituindo uma hipótese de isenção parcial.

Todavia, a evolução da jurisprudência revela que a Corte Constitucional brasileira, a partir do julgamento do Recurso Extraordinário n. ${ }^{\circ} 174.478^{220}$, em 2005, modificou o seu entendimento precedente, de modo a defender a constitucionalidade da restrição ao direito de creditamento do ICMS, em se tratando de hipótese de redução de base de cálculo.

Por meio de análise realizada com base na substância dos institutos, o referido julgado do STF equiparou a redução da base de cálculo a uma isenção parcial, pelo que a anulação do crédito do imposto estaria contemplada no quanto preceituado pelo inciso II do parágrafo $2 .^{\circ}$ do artigo 155 da Lei Maior.

Vale notar, no entanto, que poderá o ente tributante, ao estabelecer hipótese de redução de base de cálculo, no bojo de norma instituidora de incentivo fiscal que visa a incentivar determinado bem ou serviço, prever expressamente o direito à manutenção do crédito, afastando, assim, questionamentos a esse respeito. Contudo, tal previsão seria, sob o ponto de vista teleológico, desnecessária, haja vista que somente se terá efetivo estímulo fiscal se o creditamento for permitido, sendo o estorno responsável por esvaziar todo o seu conteúdo.

\subsubsection{Alíquota zero}

A figura desonerativa da alíquota zero foi instituída em nosso ordenamento jurídico como mecanismo para que os Estados não perdessem arrecadação do então ICM, já que a

\footnotetext{
220 Acórdão Supremo Tribunal $\quad$ Federal. Disponível $<$ http://www.stf.jus.br/portal/jurisprudencia/listarJurisprudencia.asp?s1=\%28RE\%24\%2ESCLA $\% 2 \mathrm{E}+\mathrm{E}+17$ 4478\%2ENUME\%2E \%29+OU+\%28RE \%2EACMS $\% 2 \mathrm{E}+\mathrm{ADJ} 2+174478 \% 2 \mathrm{EACMS} \% 2 \mathrm{E} \% 29 \&$ base=base Acordaos>. Acesso em: 6 jul. 2012.
} 
Constituição Federal de 1967, em seu art. 20, § 2. ${ }^{\circ}$, autorizava que a União instituísse isenção também em relação a impostos estaduais e municipais, de modo que, sempre que a União isentasse as importações dos impostos federais, tal isenção alcançaria o antigo $\mathrm{ICM}^{221}$.

Tendo em vista o conflito de interesses com os Estados, optou-se então por, alternativamente, reduzir a zero a alíquota do imposto de importação, hipótese que permitiria a União prosseguir no fomento às importações, sem que os Estados sofressem a perda de arrecadação do ICM.

Cumpre consignar que o referido mecanismo encontrou eco na jurisprudência do Supremo Tribunal Federal, que o consolidou por meio da Súmula 576, de 3.1.1977: "É lícita a cobrança do imposto de circulação de mercadoria sobre produtos importados sob o regime da alíquota 'zero'."

Entretanto, a figura em comento não é admitida de forma incontroversa. Sacha Calmon Navarro Coêlho ${ }^{222}$ defende que a redução da alíquota deve ser parcial, afastando a existência da redução da alíquota total:

As reduções de bases de cálculo e de alíquotas decorrem do modo de calcular o conteúdo pecuniário do dever tributário, determinando uma forma de pagamento - elemento liberatório do dever - que implica, necessariamente, uma redução do quantum tributário em relação à generalidade de contribuinte (ou em relação à situação impositiva imediatamente anterior).

Tecnicamente, as reduções de bases de cálculo e de alíquotas nos mandamentos normativos deveriam ser sempre parciais, porquanto as exonerações totais já são atendidas através das fórmulas isentantes e imunizantes. A atuação do legislador sobre o dever tributário, minimizando-o por razões extrafiscais, deveria cingir-se àquelas hipóteses em que, não querendo dar exoneração integral, preferisse apenas reduzir o quantum debeatur. Haveria o dever tributário, a obrigação tributária, todavia o quantum a pagar seria menor. Com efeito, não faz sentido dizer que da ocorrência do fato y (hipótese de incidência) deve ser a prestação (consequência jurídica imputada ao suposto), mas, ao determiná-la, dizer que é nenhuma, porque não há base de cálculo ou não há alíquota (alíquota zero).

${ }^{221}$ GROFF, Leandro Morais. Isenção, alíquota zero e o princípio da não cumulatividade. Revista Tributária e de Finanças Públicas, São Paulo, v. 15, n. 76, p. 164, set.-out. 2007.

${ }^{222}$ COÊLHO, Sacha Calmon Navarro. Op. cit., p. 213. 
Considerando que tanto a alíquota zero quanto a isenção implicam a inexistência de tributo a ser pago, parte da doutrina acaba por equiparar tais institutos. Ressalte-se a manifestação de Aroldo Gomes de $\operatorname{Mattos}^{223}$ :

3.10 - Destarte, não se reveste de cunho científico a especiosa distinção feita por determinados julgados entre isenção e alíquota zero ou alíquota reduzida, já que os efeitos jurídicos dessas formas exonerativas são exatamente os mesmos, ou seja, obstaculizar o nascimento da obrigação tributária.

Ao analisar o IPI, Souto Maior Borges ${ }^{224}$ posicionou-se na mesma linha: "Em síntese, não há incidência de norma obrigacional do IPI na isenção, não tributação ou alíquota zero. Esse é um ponto comum que as reúne sob o mesmo regime jurídico exonerativo dentro do campo dos produtos industrializados". A esse respeito pronunciouse o Superior Tribunal de Justiça ${ }^{225}$ :

Tributário. Mercadorias importadas sob alíquota reduzida. Regime equivalente à isenção, no caso, parcial. Direito do contribuinte à isenção, nas mesmas proporções, do tributo estadual previsto para a mesma operação.

As figuras da isenção e da alíquota zero, ou reduzida, conquanto ontologicamente distintas para os efeitos visados pela lei, conduzem à mesma consequência jurídica, merecendo o mesmo tratamento.

Recurso não conhecido.

Noutro sentido, assim se manifestou Leandro Groff ${ }^{226}$ :

Em suma, na alíquota zero, há polaridade; na isenção, inexistência. $\mathrm{Na}$ alíquota zero, a pergunta: "qual parcela do êxito descrito na hipótese normativa deve o sujeito passivo entregar ao Estado para contribuir na manutenção da res publica?", recebe a resposta: "a menor possível: zero". Já na isenção, a pergunta: "qual parcela do êxito descrito na hipótese normativa deve o sujeito passivo entregar ao Estado para contribuir na manutenção da res publica?", recebe a resposta: "inexistem critérios no texto do direito positivo para compor esse juízo". Norma individual e concreta que documenta a incidência (plano concreto). Salto esse que, por certo, não é metodologicamente aconselhável à pretendida equiparação.

${ }^{223}$ MATTOS, Aroldo Gomes de. O imposto de renda frente ao ICMS remitido como subvenção para investimento. Revista Tributária e de Finanças Públicas, São Paulo, v. 15, p. 181, abr. 1996.

${ }^{224}$ BORGES, José Souto Maior. Op. cit., p. 354.

225 STJ, REsp 7218/SC (1991/0000329-8), Rel. Min. Ilmar Galvão, Segunda Turma, DJ 06.05.1991. Disponível em: <http://www.stj.jus.br/SCON/pesquisar.jsp>. Acesso em: 8 jan. 2012.

${ }^{226}$ GROFF, Leandro Morais. Op. cit., p. 161. 
Nota-se, com base no exposto, que o instituto sob exame é diverso da isenção (foi instituído justamente para sanar dificuldades identificadas na aplicação da isenção), porém, na linha do entendimento do professor Paulo de Barros Carvalho ${ }^{227}$, para quem a alíquota zero impede que a relação obrigacional se concretize à míngua de objeto, identifica-se aproximação entre os institutos em foco, uma vez que ambos abalam os critérios da regra matriz de incidência da norma tributária, o que torna suas naturezas jurídicas semelhantes.

Neste compasso, para fins de instituição de incentivos fiscais, cabe aqui conhecer as características de cada um desses institutos e optar pelo mais adequado. Assim é que, em se tratando de situações que demandam um estímulo emergencial e transitório, afigura-se mais adequada a redução a zero da alíquota, em vez de se isentar determinado produto e voltar a tributá-lo, quando cessada a urgência.

\subsubsection{Depreciação acelerada}

Máquinas, aparelhos, instrumentos e equipamentos destinados à incorporação ao ativo imobilizado possuem um prazo de vida útil limitado e, em virtude do seu uso, entram em processo de desgaste. Tal deterioração, que resulta na diminuição da utilidade e também do valor dos mencionados bens, deve ser reconhecida por meio da depreciação contábil.

Uma vez que o valor da depreciação influi no resultado do exercício de uma empresa, pois se classifica como uma despesa, não há dúvidas de que, se esta for lucrativa, em termos tributários, será vantajoso que os abatimentos a título de depreciação sejam os maiores possíveis, reduzindo-se, assim, o montante do Imposto de Renda e da Contribuição Social.

Raciocínio diverso é aplicado à empresa com lucratividade tributária comprometida, sendo, em regra, mais conveniente que as despesas de depreciação sejam apropriadas em um intervalo maior de tempo, adiando-se o seu reconhecimento.

\footnotetext{
227 Paulo de Barros Carvalho defende que a alíquota zero "é uma fórmula inibidora da operatividade funcional da regra-matriz, de tal forma que, mesmo acontecendo o evento tributário, no nível da concretude real, não pode o fato ser constituído e seus peculiares efeitos não se irradiam, justamente porque a relação obrigacional não se poderá instalar à míngua de objeto" (Op. cit., p. 930).
} 
No Brasil, a legislação permite que o contribuinte utilize taxas de depreciação que reflitam a vida útil econômica dos bens. De tal maneira, caso a vida útil de determinado equipamento esteja indicada pela Receita Federal do Brasil como de 10 anos e a empresa entenda ser de oito anos, é possível a confecção de prova em contrário para demonstrar o seu posicionamento.

As provas devem ser realizadas com base em laudos técnicos especializados e, em caso de controvérsia, o contribuinte pode ainda requerer perícia do Instituto Nacional de Tecnologia ou de outra entidade oficial de pesquisa científica ou tecnológica, devendo, então, prevalecer os prazos de vida útil fixados pelas aludidas instituições (Lei 4.506/1964, art. $\left.57, \S 4 .^{\circ}\right)$.

Os referidos prazos, que refletem a vida útil do bem, podem vir a ser reduzidos, hipótese em que se estará diante da figura da depreciação acelerada. Há duas espécies de depreciação acelerada.

A primeira refere-se à possibilidade da depreciação acelerada contábil de máquinas e equipamentos quando as indústrias estabelecem turnos extraordinários para atender a sua demanda. A legislação permite realizar a depreciação acelerada em face do desgaste maior de tais bens de produção. Tal hipótese resulta do uso em regime de operação superior ao normal, dimensionado com base no número de horas diárias de operação. A dedutibilidade de tais despesas é prevista no art. 312 do RIR/1999 228 .

Há, também, a depreciação acelerada incentivada, que consubstancia incentivo fiscal e é reconhecida, tão somente, pela legislação tributária para fins da apuração do lucro real, sem nenhum registro contábil (RIR/1999, art. 313).

Por se pautar pela análise dos incentivos fiscais, o presente trabalho passa a tratar, a seguir, apenas da depreciação acelerada que busca o estímulo a determinada atividade por meio de tratamento fiscal diferenciado.

O estímulo decorre do fato de a depreciação acelerada provocar o diferimento da tributação para um período subsequente, agindo tal qual um empréstimo sem juros. Esses benefícios diminuem o custo de aquisição dos bens sujeitos à depreciação.

\footnotetext{
${ }^{228}$ O critério contábil para a aplicação da depreciação acelerada dos bens móveis é pautado no número de horas diárias de operação, aplicando-se os seguintes coeficientes de depreciação acelerada sobre as taxas normalmente utilizáveis: 1,0 - para um turno de oito horas de operação; 1,5 - para dois turnos de oito horas de operação e 2,0 - para três turnos de oito horas de operação (RIR/1999, art. 312). De tal maneira, se a taxa normal de depreciação de certo bem é de $10 \%$ ao ano, a depreciação será de $15 \%$ ao ano, caso haja operação de 16 horas por dia, ou de $20 \%$ ao ano, se esta for de 24 horas por dia.
} 
Ao abordar essa espécie de depreciação acelerada, Elcio Fiori Henriques ${ }^{229}$ a inclui no rol das hipóteses gerais de concessão de prazos mais favorecidos para o pagamento de tributo para determinadas situações e contribuintes.

Segundo o referido autor, as normas favorecidas de depreciação são veiculadas por meio de mecanismos intrínsecos à sistemática de quantificação do dever tributário e possuem como característica a redução do prazo de amortização comum aplicável para certos investimentos, tendo como efeito financeiro a elevação artificial das despesas no início do período depreciativo, de modo a reduzir o valor amortizável dos momentos finais. Portanto, concede-se ao contribuinte a postergação do pagamento dos tributos sobre o lucro.

Com efeito, por intermédio de tal mecanismo, a dedução do imposto correspondente à depreciação do bem, que deveria ser fracionada ao longo do tempo, acaba sendo efetivada em menor tempo, aliviando, assim, o investidor que despendeu recursos ao investir em bens para sua operação.

Nesta diretriz, com o fim de estimular a ampliação, modernização ou diversificação realizadas em setores da economia tidos como prioritários para o desenvolvimento regional, a Lei n. ${ }^{\circ} 11.196$, de 21 de novembro de 2005, instituiu a depreciação acelerada incentivada para aquisições de bens de capital efetuadas por pessoas jurídicas estabelecidas em microrregiões menos favorecidas localizadas nas áreas de atuação das extintas Sudene e Sudam.

O incentivo previsto pela mencionada norma consiste na depreciação integral do bem adquirido no próprio ano da sua compra. De tal modo, o incentivo tem como consequência a redução do Imposto de Renda e Contribuição Social sobre o lucro líquido do exercício, observado, no entanto, o limite do custo da aquisição do bem.

Verifica-se que tal alteração do prazo de depreciação constitui técnica que visa a reduzir antecipadamente a tributação daqueles que promovem investimentos considerados estratégicos para o Estado, consubstanciando estímulo àquele contribuinte que incorre em gastos que impactarão positivamente no desenvolvimento de regiões menos atrativas, por exemplo.

${ }^{229}$ HENRIQUES, Elcio Fiori. Op. cit., p. 262. 


\subsubsection{Remissão}

A remissão é um perdão a partir do qual o sujeito passivo fica dispensado de pagar o tributo total ou parcialmente e, a teor do $\S 6 .^{\circ}$ do art. 150 da Lei Maior, só poderá ser concedida mediante lei específica.

Com efeito, a figura em testilha, disciplinada pelo art. 172 do Código Tributário Nacional, constitui uma hipótese de extinção de obrigação tributaria já existente, pressupondo a realização concreta do fato gerador ${ }^{230}$, o que a torna distinta de outros institutos do Direito Tributário, como a isenção.

Sacha Calmon Navarro conceitua de forma simples e objetiva a remissão ao afirmar que este instituto "é ato unilateral do Estado-legislador, por motivos elevados e não por simples favor, o que seria contrário aos princípios da igualdade e da capacidade contributiva. A remissão tributária é, portanto, literalmente, dispensa de pagamento de tributo devido. [...] Remissão é dispensa de crédito". 231

\subsubsection{Anistia}

De sua parte, a anistia é o perdão das penalidades pecuniárias integrantes da obrigação tributária.

Regina Helena Costa, ao diferenciar anistia da remissão, pontifica que "esta também constitui espécie de perdão, mas possui outro objeto: as infrações fiscais. Mediante a concessão de anistia pode-se perdoar uma infração à lei tributária ou, apenas, a sanção dela decorrente" 232 .

Registre-se posição de Roque Carrazza, para quem a anistia "perdoa, total ou parcialmente, a sanção tributária, isto é, a multa decorrente do ato ilícito tributário. Incide sobre a infração tributária, desconstituindo sua antijuridicidade. Por evidente, aparta-se do tributo, que não compreende a sanção de ato ilícito" ${ }^{233}$.

\footnotetext{
${ }^{230}$ BORGES, José Souto Maior. Isenções tributárias. São Paulo: Sugestões Tributárias, 1969. p. 200.

${ }^{231}$ COÊLHO, Sacha Calmon Navarro. Op. cit., p. 828 e 830.

${ }^{232}$ COSTA, Regina Helena. Curso de direito tributário: Constituição e Código Tributário Nacional. São Paulo: Saraiva, 2009. p. 266.

${ }^{233}$ CARRAZZA, Roque Antonio. Op. cit., p. 830.
} 
Destaque-se que o instituto em apreço somente pode ser instituído por lei específica e independe do lançamento das sanções pecuniárias, não se aplicando a quem pratica crimes e age com dolo e má-fé. Sobre esse assunto, elucidativa a lição de Luciano Amaro $^{234}$ :

Anistia é o perdão de infrações, do que decorre a inaplicabilidade da sanção. Não é a sanção que é anistiada; o que se perdoa é o ilícito; perdoado este, deixa de ter lugar a sanção; o perdão, portanto, toma o lugar da sanção, obstando a que esta seja aplicada.

\section{$[\ldots]$}

A anistia exclui a punibilidade da infração (punibilidade que existia efetivamente, e, com a anistia, deixou de existir). $O$ fato de, eventualmente, o Fisco já ter notificado o infrator para recolher penalidade pecuniária aplicável à infração também não impede o reconhecimento da anistia.

Sobre a diferença entre anistia e remissão importa esclarecer que, "na concessão do perdão, o objeto da remissão é o tributo devido, e o da anistia é a infração praticada"235. Enquanto a remissão dispensa o pagamento do tributo, a anistia dispensa o pagamento das multas que punem o descumprimento da obrigação acessória. ${ }^{236}$

Quando concedida de forma limitada, "sob condição do pagamento do tributo no prazo fixado pela lei [...]"237, estimula o adimplemento de créditos tributários. Nessas condições é que o governo vem concedendo anistias juntamente com parcelamentos para incentivar o pagamento de tributos, independentemente do lançamento e/ou ajuizamento de ações judiciais em que são discutidos.

Contudo, quando certo contribuinte paga as penalidades exigidas e logo em seguida é concedida anistia para essa determinada penalidade, ele não é perdoado, não se aplicando a anistia. Com isso, essas concessões não são bem-vistas pelos bons pagadores, desagradando a quem, espontaneamente, cumpriu com suas obrigações, ainda que com atraso (multas e juros).

\footnotetext{
${ }^{234}$ AMARO, Luciano. Op. cit., p. 455.

${ }^{235}$ Id. Ibid., p. 456.

${ }^{236}$ COÊLHO, Sacha Calmon Navarro. Op. cit., p. 855.

${ }^{237}$ Art. 181 do Código Tributário Nacional:

A anistia pode ser concedida:

[...]

II - limitadamente:

$[\ldots]$

d) sob condição do pagamento de tributo no prazo fixado pela lei que a conceder, ou cuja fixação seja atribuída pela mesma lei à autoridade administrativa.
} 
Nesse sentido, é importante que os entes tributantes, ao concedê-las, demonstrem os fins a que visam alcançar, evitando, assim, a violação à isonomia.

Explicitadas as principais figuras por meio das quais os incentivos fiscais podem manifestar-se, passa-se a tratar dos requisitos formais e materiais indispensáveis à sua instituição.

Assim, além da competência para veiculação de incentivos fiscais, serão alvo de exame os princípios constitucionais norteadores do instituto em voga.

\subsection{Limites à concessão de incentivos fiscais}

\subsubsection{Competência}

Como já foi dito linhas acima, a competência tributária emana do poder de tributar, dela se valendo os entes políticos para o exercício de tal poder.

A Lei Maior, ao repartir e demarcar as fronteiras a que os entes arrecadantes estariam adstritos, também autorizou a abstenção ao exercício da competência tributária.

Na Seção II, que trata das "Limitações Constitucionais ao Poder de Tributar", o constituinte previu expressamente que as figuras da isenção, da redução de alíquota, da concessão de crédito etc., que geram desoneração tributária, poderiam ser implementadas, desde que por meio de lei específica, exarada pelo legislador federal, municipal ou estadual, in verbis:

Art. 150. Sem prejuízo de outras garantias asseguradas ao contribuinte, é vedado à União, aos Estados, ao Distrito Federal e aos Municípios:

\section{$[\ldots]$}

6. ${ }^{\circ}$ Qualquer subsídio ou isenção, redução de base de cálculo, concessão de crédito presumido, anistia ou remissão, relativos a impostos, taxas ou contribuições, só poderá ser concedido mediante lei específica, federal, estadual ou municipal, que regule exclusivamente as matérias acima enumeradas ou o correspondente tributo ou contribuição, sem prejuízo do disposto no art. $155, \S 2 .^{\circ}, \mathrm{XII}, \mathrm{g}$. 
Saliente-se que a ressalva contida na parte final do dispositivo supratranscrito, quanto ao conteúdo do art. $155, \S 2 .^{\circ}$, XII, g, correspondente à exceção específica do ICMS, segundo a qual "isenções, incentivos e benefícios fiscais" devem ser concedidos e revogados com base nos critérios previstos em lei complementar ${ }^{238}$.

Com efeito, todo tratamento tributário diferenciado, seja mediante a concessão de crédito presumido e de isenção, seja por meio da redução de alíquota, deve ser efetivado pela pessoa jurídica de direito público competente para impor a correlata exação.

Nesta senda, pontua Marcos André Vinhas Catão ${ }^{239}$ : “[...] desde já, assentamos que os incentivos fiscais, não obstante a necessidade de atendimento aos requisitos formais e principiológicos para a sua concessão, se estruturam a partir de norma expedida pelo próprio ente político competente à instituição do tributo que lhe foi outorgado na atribuição de competências".

A despeito de tal conclusão parecer evidente hoje, o fato é que já houve, no ordenamento jurídico brasileiro, a permissão para que um ente arrecadante isentasse, em determinadas situações, tributos de competência de outro ente. Tal autorização era prevista pelo art. 19, § 2. ${ }^{\circ}$, da Constituição de 1967, segundo o qual a União, por força de relevante interesse social e econômico nacional, poderia instituir isenções de impostos federais, estaduais e municipais.

Feitas tais considerações acerca da titularidade para a instituição de incentivos fiscais, cabe assinalar que a competência para reduzir a tributação está vinculada aos mesmos princípios e regras que limitam o poder de tributar. Assim é que, em obra voltada ao estudo das isenções tributárias, o professor Souto Maior Borges leciona que o "poder de isentar é o próprio poder de tributar visto ao inverso". E $\operatorname{arremata}^{240}$ :

Em virtude do princípio jurídico da supremacia da Constituição, a teoria jurídica da isenção tributária há de apoiar-se, como se viu, em normas constitucionais que autorizam e delimitam o exercício da competência tributária pelo legislador ordinário. Radica na própria Constituição Federal o poder de isentar.

Na outorga constitucional de competência tributária está necessariamente contida a atribuição da faculdade de isentar. Neste sentido, pode-se afirmar que o poder de isentar é corolário do poder de tributar.

\footnotetext{
${ }^{238}$ A Lei Complementar em foco é estudada no item 3.4.2.

${ }^{239}$ CATÃO, Marcos André Vinhas. Op. cit., p. 11-12.

${ }^{240}$ BORGES, José Souto Maior. Teoria geral da isenção tributária, cit., p. 31.
} 
Existe uma conexão necessária entre o regime jurídico-material da tributação e o das isenções [...].

Deveras, constata-se que os incentivos fiscais não só são veiculados pelo mesmo ente político que detém competência para instituir o correlato tributo, como também estão adstritos aos princípios e regras balizadores do poder de tributar $^{241}$.

Vale destacar que, uma vez que a norma tributária instituidora de incentivo fiscal busca, primordialmente, induzir comportamentos, é imprescindível que o ente tributante detenha competência material para regular o respectivo substrato fático e jurídico a ser fomentado via tributação.

Nesse sentido, considerando que a competência legislativa se acha preconizada nos artigos 22 e seguintes da Lei Maior e que as mencionadas normas tributárias indutoras versarão sobre as matérias ali contidas, esses veículos legislativos irão se sujeitar a tais preceitos constitucionais. Por essa razão, o ente interessado em criar incentivo fiscal deverá possuir as competências tributária e legislativa, concomitantemente ${ }^{242}$.

De tal sorte, o ente político interessado em conceder um incentivo fiscal, verificando que detém competência tributária para moldar determinada exação fisscal e que possui competência material para disciplinar a conduta que pretende fomentar por meio de tal veículo tributário, deverá voltar-se para o atendimento de outras diretrizes constitucionais; dentre elas, as de maior relevo são a legalidade, a isonomia, a capacidade contributiva e a livre concorrência.

Nesta toada, desenvolver-se-á, no item que segue, o conteúdo geral dos mencionados princípios, bem como a sua conformação no âmbito da extrafiscalidade, em que se encontra o incentivo fiscal. Ademais, será analisada a relação entre a veiculação do aludido instituto e a capacidade contributiva.

\footnotetext{
${ }^{241}$ Leila Paiva aduz que a norma jurídica tributária extrafiscal "deve emanar da mesma pessoa jurídica de direito público que tem competência para estabelecer a norma jurídica tributária fiscal. Além disso, simplificando, ao máximo, é possível afirmar que, sob a perspectiva pragmática, a norma tributária extrafiscal relaciona-se com o sistema jurídico, segundo os mesmos padrões de calibração e imunização observados pelas normas tributárias fiscais" (PAIVA, Leila. Disciplina jurídica da extrafiscalidade. 1994. Dissertação (Mestrado) - Faculdade de Direito, Universidade de São Paulo, São Paulo, p. 20).

${ }^{242}$ SCHOUERI, Luís Eduardo. Normas tributárias indutoras e intervenção econômica, cit., p. 351.
} 


\subsubsection{Legalidade}

$\mathrm{Na}$ esteira das Cartas Políticas cunhadas após a Segunda Guerra Mundial, a Constituição Federal de 1988 cuidou de criar mecanismos visando a limitar a atuação do ente estatal, prestigiando, no seu bojo, vasta gama de direitos e garantias individuais.

Assim, com o fito de impedir que as intervenções a tais direitos e garantias não ficassem à mercê da vontade do Estado, a Carta Política incluiu como garantia fundamental, no seu art. 5. ${ }^{\circ}$, II, o princípio da legalidade, segundo o qual ninguém será obrigado a fazer ou deixar de fazer alguma coisa senão em virtude de lei.

Além de ter estabelecido que os atos estatais na esfera particular não poderiam ser movidos pela discricionariedade, o constituinte buscou exigir expressamente que a veiculação de obrigações de cunho tributário também estivesse adstrita à lei formal. Nesta perspectiva, o primado em testilha foi cristalizado na seção dedicada às limitações constitucionais ao poder de tributar, em que restou proibido que se exigisse ou aumentasse tributo sem lei que o estabelecesse.

De sua parte, o Código Tributário Nacional - CTN estatuiu, no seu art. 97, as matérias que devem obediência à lei. Com lastro em tal preceito, o estabelecimento de base de cálculo e a fixação de alíquota devem ser efetivados por ato normativo emanado do Poder Legislativo.

Com efeito, o ordenamento jurídico pátrio não só atribuiu competência ao Poder Legislativo para veiculação de norma impositiva tributária (legalidade formal), como também estipulou que o respectivo comando legal deverá "esgotar, como preceito geral e abstrato, os dados necessários à identificação do fato gerador da obrigação tributária e à quantificação do tributo, sem que restem à autoridade poderes para, discricionariamente, determinar se 'A' irá ou não pagar tributo, em face de determinada situação"²43 (legalidade material).

Desse modo, o primado da legalidade irá demandar que o ente tributante, ao criar tributo, faça-o de maneira a permitir a identificação de todos os seus elementos estruturantes, viabilizando, assim, sua aplicação concreta.

${ }^{243}$ AMARO, Luciano. Op. cit., p. 112. 
Neste contexto, o vetor em foco adquire maior rigidez no campo tributário, sendo difundida a aplicação da reserva absoluta de lei formal ou estrita legalidade, que consiste, para Alberto Xavier, ${ }^{244}$ "na necessidade de que toda a conduta da Administração tenha seu fundamento positivo na lei, ou, por outras palavras, que a lei seja o pressuposto necessário e indispensável de toda a atividade administrativa”.

Muito embora a exação fiscal pressuponha a existência de lei em sentido formal e material, é possível que o legislador deixe a cargo do Poder Executivo a disciplina de pormenorizações que facilitem a compreensão do conteúdo legal. Portanto, atos normativos irão esmiuçar o teor legal.

Registre-se, inclusive, que, em muitos casos, a fruição de determinado direito previsto em lei dependerá de ato concessório, da lavra de órgão técnico especializado.

Outro aspecto a ser ressaltado, especialmente no âmbito da extrafiscalidade, é a inclusão, na própria estrutura da norma, de conceitos indeterminados e cláusulas gerais, que deverão ser detalhados e aplicados por órgão do Executivo.

Note-se que os conceitos indeterminados e as cláusulas gerais são adaptações da norma que conferem maior abertura ao seu conteúdo, para que haja máximo ajuste às peculiaridades do caso concreto, possibilitando, pois, a concretização do objetivo da tributação extrafiscal na maior medida possível.

Tal recurso, contudo, não pode ser compreendido como permissão à arbitrariedade do aplicador da norma. Deve-se buscar o comando legal que se revele mais condizente com o objetivo a que se volta a norma tributária.

Sobreleve-se que as normas tributárias albergam conceitos indeterminados, sendo, no entanto, mais recorrente a sua ocorrência no âmbito dos incentivos fiscais. Assim, por exemplo, a Lei Rouanet (Lei n. ${ }^{\circ} 8.313 / 1991$ ), que institui o Programa Nacional de Apoio à Cultura, no seu artigo 1. ${ }^{o}$ aduz ser a finalidade do programa: i) contribuir para facilitar, a todos, os meios para o livre acesso às fontes da cultura e o pleno exercício dos direitos culturais, ii) salvaguardar a sobrevivência e o florescimento dos modos de criar, fazer e viver da sociedade brasileira; e iii) preservar os bens materiais e imateriais do patrimônio cultural e histórico brasileiro.

\footnotetext{
${ }^{244}$ XAVIER, Alberto. Tipicidade da tributação, simulação e norma antielisiva. São Paulo: Dialética, 2001. p. 35 .
} 
Advirta-se que a utilização dos referidos recursos linguísticos não significa que o legislador possa deixar de elaborar normas claras, compreensíveis pelos destinatários e passíveis de controle judicial.

Destarte, a aplicação dos referidos recursos no âmbito do incentivo físcal deverá estar ajustada aos vetores constitucionais e legais que norteiam o instituto, sendo evidente a possibilidade de controle judicial de qualquer ato administrativo que, a pretexto de conferir concretude a conceitos indeterminados e cláusulas gerais, se mostre afastado das aludidas diretrizes que lhe são pertinentes.

Cumpre salientar que, no âmbito dos incentivos fiscais, esse cânone demanda requisito formal próprio, porquanto a Lei Maior, por meio do $\S 6 .^{\circ}$ do art. 150 da $\mathrm{CF}$, exige lei formal específica para a instituição dos aludidos tratamentos fiscais diferenciados.

Assim, buscou o legislador constituinte evitar que incentivos fiscais fossem criados em sede de leis genéricas, que cuidam de inúmeras matérias, prejudicando, ao final, a transparência em relação ao conteúdo e ao alcance do instituto.

A imposição em tela facilita o acesso e o exame da atratividade do incentivo por todos aqueles agentes alcançáveis pela norma, sem falar na ampliação do controle da sua idoneidade, impedindo assim que interesses particulares restem camuflados num emaranhado de normas dispostas em diplomas legais que versam sobre uma infinidade de matérias.

Ademais, o operador do Direito não terá de realizar uma complicada busca, revolvendo toda legislação, para identificar a criação ou a revogação de determinado estímulo fiscal.

A exigência de um diploma legal específico irá pressupor que a ementa da lei evidencie de forma nítida e destacada o incentivo fiscal disciplinado. A prática revela, todavia, a edição de Medidas Provisórias que versam sobre diversas matérias, incluindo-se incentivos fiscais, em nítido desrespeito ao quanto estipulado pela Lei Maior.

A Constituição Federal, em relação aos incentivos fiscais concedidos no âmbito do ICMS, impõe exigência adicional, contida no art. 155, $\S 2 .^{\circ}$, XII, segundo a qual tal instituto deverá seguir prescrições gerais albergadas em sede de lei complementar. Atualmente, a referida disciplina é veiculada pela Lei Complementar n. ${ }^{\circ}$ 24/1975. 
A lei complementar em foco, editada sob a égide da Constituição de 1967, foi recepcionada pela Constituição Federal de 1988. Uma das exigências verificadas é que os incentivos fiscais, benefícios fiscais e financeiros estaduais sejam previamente amparados em convênio aprovado à unanimidade pelos representantes dos Estados que compõem o CONFAZ - Conselho Nacional de Política Fazendária.

Todavia, como a obtenção da totalidade de votos é muito difícil de ser alcançada, os Estados passaram a conceder unilateralmente incentivos, à revelia da chancela do Órgão em foco. A proliferação dessa prática instaurou no país a denominada guerra fiscal. Nesse sentido, vale ressaltar que o STF, depois de julgar repetidas Ações Diretas de Inconstitucionalidade reputando inconstitucionais as leis estaduais que não respeitaram o aludido requisito formal, anunciou proposta de edição de Súmula Vinculante de n. ${ }^{\circ}$ 69, com o conteúdo a seguir reproduzido:

Qualquer isenção, incentivo, redução de alíquota ou de base de cálculo, crédito presumido, dispensa de pagamento ou outro benefício fiscal relativo ao ICMS, concedido sem prévia aprovação em convênio celebrado no âmbito do CONFAZ, é inconstitucional.

Um número recorde de manifestações foi apresentado perante a Suprema Corte. Diversos Estados defendem que os tratamentos fiscais e financeiros mais vantajosos foram concedidos para o fomento de suas respectivas economias, sendo indispensável ao incremento das condições sociais, principalmente das regiões com déficit de desenvolvimento. Neste contexto, o Governo Federal e o Congresso Nacional (notadamente o Senado) estão elaborando formas de equalizar esse problema, prevendo a instituição de fundos e a uniformização das alíquotas interestaduais, dentre outras medidas.

É certo que os incentivos fiscais unilaterais configuram violação formal a comando

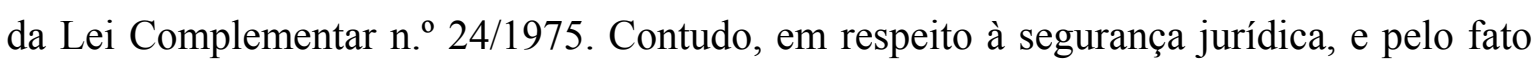
de tais estímulos terem figurado como mecanismos amenizadores das diferenças regionais, o que constitui objetivo plasmado ao longo de todo o texto constitucional ${ }^{245}$, a solução do

\footnotetext{
${ }^{245}$ A Constituição de 1988 aborda a questão da busca pela redução das desigualdades regionais em diversos dispositivos: no art. 3. ${ }^{\circ}$, esta figura no rol dos objetivos fundamentais da República Federativa; o art. 43 determina que a União articule suas ações visando ao desenvolvimento e à redução das desigualdades regionais; o art. 151, inciso I, excepciona a universalidade e generalidade da tributação para promoção do equilíbrio do desenvolvimento socioeconômico entre as diferentes regiões do País; o art. 165 estipula que os orçamentos do Poder Executivo terão como função reduzir desigualdades inter-regionais; e o art. 170, inciso VII, erige como princípio da ordem econômica a redução das desigualdades regionais e sociais. Ademais, o princípio da isonomia, de que trata o art. $5 .^{\circ}$, irá determinar que se adote o critério de discrímen em comento.
} 
problema da guerra fiscal deverá contar, dentre outras medidas, com a convalidação dos incentivos já concedidos.

\subsubsection{Igualdade e proporcionalidade}

De inspiração aristotélica, o primado da igualdade demanda que as situações semelhantes recebam tratamento igual e as situações diferentes, tratamentos diversos.

Aliomar Baleeiro ${ }^{246}$, ainda sob os auspícios da Constituição de 1946, asseverou que se todos são iguais perante a lei, não sendo possível a promoção de tratamento diverso aos indivíduos que se encontram em condições semelhantes, tornam-se descabidas as discriminações incompatíveis com o sistema constitucional.

Na Carta Política de 1988, o princípio da isonomia afigura-se diretriz fundamental, que determina de forma genérica, no seu art. $5^{\circ}$, a igualdade entre os cidadãos. Impõe-se, assim, o banimento de todas as formas de privilégios e discriminações injustificadas.

Deveras, o aludido princípio, nos moldes em que cunhado pelo legislador constituinte, não só revela a igualdade formal (perante a lei), como também deixa inequívoca a igualdade material (igualdade na lei).

Nesta senda, o aplicador do Direito deverá, necessariamente, conferir tratamento semelhante a situações jurídicas idênticas (igualdade horizontal), bem como deverá realizar diferenciações, no caso de situações distintas (igualdade vertical). De igual maneira, deve se pautar a atuação do Executivo, Judiciário e dos demais operadores do Direito.

$\mathrm{Na}$ seara tributária, o princípio em foco determina a realização de uma tributação justa, sem distinções arbitrárias. Nos termos do art. 150, II: “é vedado à União, aos Estados e aos Municípios: [...] II - Instituir tratamento desigual entre contribuintes que se encontrem em situação equivalente, proibida qualquer distinção em razão da ocupação profissional ou função por eles exercida, independente da denominação jurídica dos rendimentos, título ou direitos".

Vale ressaltar que a igualdade tributária está atrelada à ideia de generalidade e de uniformidade. Assim, a generalidade irá impor que o dever de contribuir se espraie por todos, de modo a não excluir ninguém do cumprimento da obrigação tributária.

\footnotetext{
${ }^{246}$ BALEEIRO, Aliomar. Direito tributário brasileiro, cit., p. 520.
} 
Por seu turno, a uniformidade demanda que se estabeleça um único critério para a gradação da carga tributária, de modo que haja meios de realizar uma mensuração, ainda que precária, do montante do tributo a ser exigido. Tem-se, como exemplo, a taxa, cujo valor cobrado deverá ter por critério a equivalência com o custo e com o benefício do serviço prestado pelo ente estatal.

Todavia, há de se registrar que nem sempre os veículos orientadores da generalidade e uniformidade, acima tratados, poderão ser veiculados para a concretização da igualdade, porquanto, como já dito, situações há em que se estará diante de diretrizes constitucionais que apontam para direções diversas, fazendo-se, assim, necessário o uso do tributo como instrumento para distinção de situações dessemelhantes e equiparação de situações iguais.

Deveras, o sistema constitucional brasileiro é permeado pelos mais diversos bens, valores e princípios, os quais, a depender do ângulo examinado, podem dar margem a múltiplas comparações e discriminações legais. Referidas distinções, todavia, estão sujeitas ao controle de constitucionalidade, que banirá qualquer tipo de arbítrio.

A Carta Magna elenca alguns critérios de discriminação tidos como injustificados, afastando, por exemplo, o privilégio conferido a determinadas profissões (art. 150, II e parágrafo único do art. 170 da $\mathrm{CF} / 1988)$ e o tratamento favorecido a empresas públicas e sociedade de economia mista ( $\$ 2 .^{\circ}$ do art. 173 da CF/1988).

No âmbito da tributação, alguns parâmetros são previstos pela Lei Maior, tais como: capacidade contributiva (art. 145, $\S 1 .^{\circ}$ ); essencialidade (arts. 153, $\S 3 .^{\circ}$, I e 155 , 2., X, "a" e art. 156, $\S 3^{\circ}$, II); o uso da propriedade de acordo com sua função social (art. 153, $\S 4^{\circ}$, e 182, § 4. ${ }^{\circ}$, II); localização e uso do imóvel (art. 156, § 1. ${ }^{\circ}$, II); o ato cooperativo praticado pelas cooperativas (art. 146, III, “c”); tratamento diferenciado às microempresas e às empresas de pequeno porte (art. 179), bem assim às situações que revelam desequilíbrio concorrencial (art. 146-A) ${ }^{247}$.

Além dos parâmetros identificados na seara tributária, existem também aqueles extraídos da ordem econômica, da ordem social etc. Assim, por exemplo, diversos fins constitucionais devem ser concretizados, tais como a preservação do Estado Federativo (art. 18); o apoio ao desenvolvimento da ciência e tecnologia (arts. 218 a 224); a gestão e o

\footnotetext{
${ }^{247}$ SCHOUERI, Luís Eduardo. Normas tributárias indutoras em matéria ambiental, cit., p. 245-246.
} 
controle sobre o comércio exterior (art. 237); o apoio à família (arts. 231 e 232); entre outros.

Sucede que o ente estatal não está livre para manejar tais fatores de forma a realizar distinções aleatórias. Há limites cuja transposição implica a inconstitucionalidade por violação ao princípio da igualdade.

Atento a tais fronteiras, Celso Antônio Bandeira de $\mathrm{Mello}^{248}$ estipulou quatro requisitos a serem observados para que se tenha uma lícita discriminação legal, a saber: 1) a discriminação não poderá atingir de modo atual e absoluto um único indivíduo; 2) o fator de distinção deve consistir num traço diferencial existente nas pessoas ou nas situações (não pode ser um traço alheio); 3) deve haver um nexo lógico entre o fator de discrímen e a discriminação legal estabelecida em sua razão; 4) na espécie, tal vínculo de correlação deve ser pertinente em função dos interesses constitucionalmente protegidos, visando ao bem público, à luz do texto constitucional.

Da análise dos requisitos cunhados pelo mestre da Pontifícia Universidade Católica de São Paulo, verifica-se que o autor admite as discriminações que irão afetar um certo grupo de pessoas efetivamente dotadas de traços específicos que merecem que a norma lhes confira tratamento desigual, como forma de alcançar um objetivo constitucionalmente tutelado.

Revela-se, pois, a preocupação do aludido jurista em indicar critérios aptos a impedir que discriminações sem respaldo em fim constitucional relevante tivessem palco para favorecer determinado indivíduo ou que atingissem pessoas desprovidas de traços distintivos aptos a ensejar o tratamento desigual.

Trazendo os requisitos em voga para o âmbito da tributação, verifica-se que a discriminação só poderá atingir a imposição fiscal quando o Estado pretender induzir condutas para consecução de fim constitucional, ou, até mesmo, adotar medida simplificadora do sistema tributário.

Com efeito, uma vez identificado o fim a que se busca atender, há de se analisar se este é justificado, dentro do contexto da Lei Maior. Caso positivo, impõe-se a análise do número de contribuintes atingidos e se estes realmente possuem as características

\footnotetext{
${ }^{248}$ BANDEIRA DE MELLO, Celso Antônio. O conteúdo jurídico do princípio da igualdade. 3. ed. São
} Paulo: Malheiros, 2003. p. 41. 
relacionadas logicamente com a discriminação, evitando-se, assim, o benefício a um único administrado ou àqueles que não detêm vínculo com o tratamento diferenciado.

Com base nas aludidas contribuições, a conclusão a que se chega é que igualdade tributária poderá e deverá ser relativizada, abdicando-se da generalidade e da uniformidade, sempre que uma situação específica demandar um tratamento fiscal distinto, que vise à realização de objetivo constitucionalmente justificável.

Com efeito, poderá o legislador isentar as indústrias que se instalam em determinada região menos desenvolvida, como forma de fomentar o crescimento econômico e a melhora dos indicadores sociais da região.

Tratando das normas tributárias indutoras em matéria ambiental, Luís Eduardo Schoueri defende que a proteção do meio ambiente constitui "valor suficiente para uma discriminação legal".

$\mathrm{O}$ aludido jurista reconhece que os fatores consagrados constitucionalmente para a comparação encontram-se ao longo da Carta Política (ordem tributária, ordem econômica etc.) e esclarece que cada fator, isoladamente considerado, realizará um "corte" no mundo fenomênico, segregando aqueles que atendem, ou não, àquele requisito.

Nesse sentido, Luís Eduardo Schoueri ${ }^{249}$ desenvolve o seguinte raciocínio, que ilustra bem a questão da comparação entre realidades iguais e diferentes:

[...] os "cortes" se intercruzarão, identificando-se, como resultante, "fatias" cada vez menores. Mantendo-se a figura, o teste da igualdade passa a ser feito em dois níveis: dentro de cada "fatia" e entre uma e outra "fatia". Dentro de cada "fatia", o princípio da igualdade exigirá idêntico tratamento. Trata-se de igualdade horizontal, não oferecendo qualquer dificuldade para compatibilização entre capacidade contributiva e normas tributárias indutoras, já que a própria "fatia" se define a partir do cruzamento de ambos os critérios. Maior dificuldade se terá, por outro lado, na comparação entre as "fatias", quando se buscarão critérios para a igualdade vertical.

Na ponderação surgida a partir da igualdade vertical, indagar-se-á a razão porque duas "fatias" têm tratamento diferente. Aqui, a questão é se está justificada a diferenciação. Retoma-se, agora, a premissa de que o próprio "corte" deve ser justificado, a partir dos critérios da razoabilidade motivação e nexo, acima referidos. Da combinação desses três elementos, poder-se-ão extrair critérios para proporcionalizar a própria distinção.

${ }^{249}$ SCHOUERI, Luís Eduardo. Normas tributárias indutoras em matéria ambiental, cit., p. 247. 
Em suma, o citado jurista, considerando que o ordenamento jurídico alberga inúmeros fatores de discriminação (capacidade contributiva, livre concorrência, essencialidade, defesa do meio ambiente), admite que as normas tributárias indutoras realizem as correlatas diferenciações, dividindo as situações semelhantes numa mesma "fatia". Todavia, esclarece ser necessário avaliar se a segregação efetivada passa pelo teste da razoabilidade e proporcionalidade. Ou seja, se o fator de discriminação escolhido para separar determinada situação das demais é justificado, tornando lícito o tratamento diferenciado proposto.

Nesta senda, poderá o legislador editar norma tributária indutora, criando, por exemplo, incentivo fiscal ambiental que irá excluir da incidência de determinado tributo os contribuintes que utilizam materiais reciclados como insumo. Em tal situação, cumpre investigar se esta diferenciação é proporcional, levando-se em consideração os diversos fins constitucionais contrapostos.

Outrossim, consigne-se a ponderação feita por Diego Bomfim ${ }^{250}$, para quem as normas tributárias indutoras que implicam desoneração fiscal devem figurar, no Brasil, como veículo de "implementação de políticas públicas, como instrumento de intervenção estatal sobre o domínio econômico-social voltado à realização dos objetivos e fundamentos da República (indução econômica), advindo desse contexto critérios de discrímen permitidos pelo texto constitucional, devendo haver, por certo, balizamento da exoneração pela aplicação do princípio da proporcionalidade”.

À mesma conclusão chega Humberto Ávila ${ }^{251}$, em seu livro intitulado Teoria da igualdade tributária. O referido autor parte da premissa de que, quando os tributos se destinam a atingir uma finalidade extrafiscal, em que o fim que prevalece é o alcance de objetivos de cunho econômico ou social, a medida de comparação deixa de ser a capacidade contributiva. Assim, a capacidade contributiva passa a corresponder a um elemento que detém relação de pertinência com a finalidade eleita, porém o controle da aplicação da igualdade da tributação extrafiscal estará sujeito ao teste da proporcionalidade:

A instituição de um tributo com finalidade extrafiscal, no entanto, fará com que o ente estatal se afaste, em maior ou menor medida, do ideal de igualdade particular preliminarmente instituído. Esse afastamento faz

${ }^{250}$ BOMFIM, Diego. Tributação e livre concorrência. São Paulo: Saraiva, 2011. p. 164.

${ }^{251}$ ÁVILA, Humberto. Teoria da igualdade tributária. 2. ed. São Paulo: Malheiros, 2009. p. 162. 
com que a tributação se submeta a outro tipo de controle: o controle de proporcionalidade.

O presente estudo alinha-se ao entendimento ora exposto, no sentido de que a diferenciação de tratamento, em sede de extrafiscalidade, para ser compatível com o ordenamento jurídico pátrio deverá ser proporcional, atendendo, cumulativamente, aos seus três subprincípios: adequação, necessidade e proporcionalidade no sentido estrito.

A proporcionalidade afigura-se princípio hermenêutico conformador dos princípios constitucionais conflitantes, cuja estrutura é tríplice, sendo composta pelos subprincípios: (i) adequação, (ii) necessidade e (iii) proporcionalidade em sentido estrito.

Com efeito, o princípio vertente, enquanto critério de controle da igualdade na tributação extrafiscal, somente irá validar medidas (desonerativas ou agravatórias) em que se verifique a adequação entre os meios e os fins constitucionais.

No exame da adequação da medida extrafiscal, investigar-se-á se o meio utilizado pelo Estado para atingir determinado objetivo é idôneo. Questiona-se: é possível atingir tal fim por meio de instrumentos tributários?

Humberto Ávila pondera que, em tal sede, mostra-se adequada a medida cuja realização desencadeie efeitos que contribuam para a promoção gradual da finalidade extrafiscal. Trazendo como exemplo a tributação ambiental, defende o jurista em foco que o mecanismo pelo qual a tributação é exteriorizada deve produzir efeitos que contribuam para a proteção do meio ambiente. Portanto, "o fundamento de validade da exigência da adequação decorre da própria finalidade positivamente estabelecida: a instituição mesma da finalidade pressupõe a adoção de comportamentos que levem à sua realização, deslegitimando qualquer outro" 252 .

No que concerne à necessidade, seu exame é realizado mediante a procura de outros meios menos restritivos do que o eleito pelo legislador, mas igualmente dotado de capacidade de atender ao fim almejado.

Assim, o ente estatal voltado à concretização de um fim constitucional e também à promoção do ideal de igualdade deverá optar pelo meio que promova o primeiro sem restringir desnecessariamente o segundo ${ }^{253}$.

${ }^{252}$ ÁVILA, Humberto. Teoria da igualdade tributária, cit., p. 162.

${ }^{253}$ ÁVILA, Humberto. Teoria da igualdade tributária, cit., p. 162-163. 
Em relação à proporcionalidade em sentido estrito, esta implica a ponderação acerca das vantagens e desvantagens de ser realizada tal medida idônea e necessária a atingir um fim público, mas que restringe um direito individual do particular.

Nesta perspectiva, não se ajustará à proporcionalidade em sentido estrito uma tributação extrafiscal que alcance o fim perseguido, mas às custas de uma restrição desmedida em relação a outros princípios constitucionais e à própria igualdade.

Isto porque, num Estado em que são tutelados os mais diversos interesses, a proporcionalidade irá impor soluções jurídicas conciliatórias que confiram a máxima efetividade aos princípios que entram em colisão concreta, consubstanciando sempre um juízo de adequação, necessidade e conformidade entre uma medida que estabelece uma restrição a um bem juridicamente protegido e o peso que esta assume no caso concreto.

Neste contexto, Humberto Ávila ${ }^{254}$ pontua que o fundamento de validade da proporcionalidade decorre da própria positivação dos mais variados princípios constitucionais que devem ser concretizados em conjunto. Assim, aduz que o ente estatal, ao ter de promover a ordem constitucional, ao invés de restringi-la, deverá escolher o meio que promova, na sua inteireza, mais a ordem constitucional do que a restrinja.

Eis o seu raciocínio acerca da finalidade extrafiscal como forma de justificar tratamento desigual ${ }^{255}$ :

[...] Para afastar a presunção de igualdade, não é suficiente justificar; é preciso confirmar que a medida do distanciamento da igualdade é proporcional; e, para evidenciá-lo, é preciso comprovar que a medida produz efeitos que contribuem para a realização gradual da finalidade extrafiscal (exame da adequação), que a medida é a menos restritiva aos direitos envolvidos, dentre aquelas que poderiam ter sido utilizadas para atingir à finalidade extrafiscal (exame da necessidade), e que os efeitos positivos, decorrentes da adoção da medida, aferidos pelo grau de importância e de promoção da finalidade extrafiscal, não são desproporcionais aos seus efeitos negativos, estimados pelo grau de importância e de promoção da finalidade igualitária (exame de proporcionalidade em sentido estrito). Não sendo assim, defraudada está a realização da igualdade.

Dessa forma, um incentivo fiscal atenderá ao primado da igualdade desde que, do sopesamento efetuado com base na proporcionalidade, se conclua que este i) alberga estímulo capaz de alcançar o objetivo buscado; ii) consubstancia a medida, dentre todas as outras aplicáveis, menos restritiva aos demais direitos restringidos; e iii) apresenta mais

${ }_{254}^{255}$ ÁVILA, Humberto. Teoria da igualdade tributária, cit., p. 163.

${ }^{255}$ Id., loc. cit. 
vantagens do que desvantagens, considerando-se que as restrições dele decorrentes são justificadas pela relevância do objetivo perseguido.

Neste cenário, importa notar que a existência de regiões no país com desenvolvimento econômico e social deficitário em relação a outras constitui fator de discrímen considerado pela própria Constituição apto a autorizar a concessão de incentivos fiscais.

O comando contido no art. 151 da Lei Maior, que autoriza "a concessão de incentivos fiscais destinados a promover o equilíbrio do desenvolvimento socioeconômico entre as diferentes regiões do país", resulta de ponderação feita pelo Legislador Constituinte da qual se extrai ser o tratamento fiscal diferenciado conferido aos Estados mais atrasados: i) apto a fomentar o desenvolvimento destes, ii) instrumento menos restritivo do que os demais e iii) veiculador de vantagens que suplantam as desvantagens.

Atendo-se mais detidamente à análise da proporcionalidade em sentido estrito, verifica-se que, a depender da região contemplada pelo incentivo e da atividade desenvolvida pelo contribuinte beneficiado, as vantagens decorrentes do estímulo físcal concedido serão aferidas de forma mais nítida.

Isto porque o fomento ao desenvolvimento econômico e social de uma área de extrema miséria concretiza princípios de grande relevo para o ordenamento jurídico nacional, dentre eles a dignidade da pessoa humana, o direito à vida e à alimentação, sendo, pois, mais simples a relativização das desvantagens identificadas, a exemplo do aumento da complexidade da aplicação da legislação tributária e da violação à livre concorrência.

No que se refere ao tipo de atividade, nota-se que a redução da tributação de certa indústria que utiliza mão de obra intensiva e está estabelecida numa região com alto nível de desemprego agrega fortes elementos para fundamentação das suas vantagens. Da mesma forma, são relevantes as vantagens de estímulo físcal concedido às atividades relativas a tratamento de efluentes que se instalarem em zonas industriais, marcadas pelo alto grau de emissão de resíduos líquidos poluentes.

Feitas tais considerações acerca do primado da igualdade e sua conjunção com a proporcionalidade, na análise da juridicidade do tratamento diferenciado entre contribuintes efetivada no âmbito da extrafiscalidade, cumpre pontuar que esse exame, por 
ser realizado à luz de determinadas circunstâncias fáticas e jurídicas, pode sofrer alterações ao longo do tempo.

Assim, num determinado cenário, a ponderação ora em comento acerca da adequação, necessidade e proporcionalidade em sentido estrito poderá concluir pela isonomia do tratamento tributário diferenciado conferido a determinadas regiões menos desenvolvidas do país. Entretanto, o incentivo deixará de atender ao princípio da igualdade quando as regiões incentivadas adquirirem os mesmos níveis de competitividade (infraestrutura, logística, mão de obra, centros de pesquisa, mercado consumidor significativo etc.) e índices de desenvolvimento humano das demais regiões do país. Em tal hipótese, verificar-se-á tratamento abrandado quando já houver condições de aplicação de tratamento padrão.

Diante disso, o tratamento diferenciado deve ser concedido por um prazo razoável, dentro do qual as circunstâncias que o legitimou mantêm-se as mesmas.

Portanto, com base nas ponderações até aqui desenvolvidas, conclui-se que a duração do incentivo fiscal deverá coincidir com o período em que o contexto que o motivou permanecer o mesmo, sendo afastada a possibilidade de concessão por tempo indeterminado, sem, ao menos, haver a previsão de reavaliação periódica do incentivo.

Identificadas as diretrizes que embasam a análise da isonomia dos tratamentos tributários diferenciados, passa-se ao exame da capacidade contributiva e sua manifestação no âmbito da tributação com fins fiscais e extrafiscais.

\subsubsection{Capacidade contributiva}

A capacidade contributiva consubstancia princípio constitucional a estipular que o ente estatal somente deve exigir que as pessoas físicas e jurídicas contribuam para as despesas públicas na medida das possibilidades de que dispõem para tanto, de modo que a carga tributária deve oscilar conforme as exteriorizações de riqueza.

Nesta perspectiva, irá a despesa pública ser rateada proporcionalmente entre os indivíduos que detenham (em potencial ou de modo efetivo) as riquezas asseguradas pelo Estado. 
Defende Berliri ${ }^{256}$ que o primado em voga também revela a necessidade de se separar com equidade a parcela necessária à sobrevivência do cidadão daquela que será destinada ao custeio das despesas públicas.

Com efeito, a partir daí, surgiu, na doutrina italiana a discussão acerca da diferença entre capacidade econômica e capacidade contributiva. Esta última somente teria palco após as deduções das despesas necessárias à sobrevivência digna do contribuinte e da sua família.

Contudo, a patente dificuldade na identificação do momento em que o contribuinte, dotado de capacidade econômica, passa a deter a capacidade para contribuir, fez com que essa ideia ficasse restrita às discussões teóricas, predominando o entendimento segundo o qual a capacidade econômica e a capacidade contributiva são equivalentes.

Ainda que não seja factível a identificação precisa acerca do exato instante em que se verifica a existência da capacidade contributiva, a busca pelo atendimento das condições individuais dos contribuintes, proposta pelo princípio da capacidade contributiva, evidencia o patente compromisso com a isonomia.

De fato, o princípio da capacidade contributiva propõe, exatamente, a realização de tratamento igual entre aqueles que possuem capacidade semelhante, e desigual entre aqueles que se encontram em situações diferentes.

Corroborando o entrelaçamento entre a capacidade contributiva e o princípio da igualdade, Aliomar Baleeiro ${ }^{257}$, ao tratar da isonomia, opina que a fonte principal de critérios discriminatórios para sua concretização seria a capacidade contributiva, "que recomenda a personalização do imposto e sua gradação, segundo as possibilidades econômicas do contribuinte".

Fernando Aurélio Zilveti ${ }^{258}$, em sua obra Princípios de Direito Tributário e a capacidade contributiva, defende que tal primado é válido para qualquer iniciativa do Estado de distribuir a carga da despesa pública, devendo os poderes Executivo, Legislativo e Judiciário, além de todo intérprete, aplicá-lo. Para o mencionado autor, a capacidade contributiva está atrelada à ideia de justiça distributiva, que propugna a tese igualitária de que se deve dar a cada um o que é seu.

\footnotetext{
${ }^{256}$ BERLIRI, Antonio. Scritti Scelti di diritto tributário. Milano: Giuffrè, 1990. p. 13.

${ }^{257}$ BERLIRI, Antonio. Op. cit., p. 13.

${ }^{258}$ ZILVETI, Fernando Aurélio. Princípios de direito tributário e a capacidade contributiva. São Paulo: Quartier Latin, 2004. p. 163-164.
} 
De forma lapidar, Alfredo Augusto Becker ${ }^{259}$ cunhou a expressão "signos presuntivos de riqueza" para designar o substrato sobre o qual a tributação deve incidir.

Em obra decorrente de dissertação de mestrado, intitulada Princípio da Capacidade Contributiva, Regina Helena $\operatorname{Costa}^{260}$ lista diversas acepções do preceito em destaque:

Assim é que, na doutrina, encontramos plúrimos entendimentos sobre o conceito. Para Griziotti, precursor das preocupações jurídicas em torno do tema, o princípio indica a "potencialidade que possuem os submetidos à soberania fiscal para contribuir para os gastos públicos". Rubens Gomes de Sousa definiu capacidade contributiva como a "soma de riqueza disponível depois de satisfeitas as necessidades elementares de existência, riqueza essa que pode ser absorvida pelo Estado sem reduzir o padrão de vida do contribuinte e sem prejudicar as suas atividades econômicas". Emílio Giardina a entende como a "possibilidade econômica de pagar tributo", enquanto Moschetti a vê como a "força econômica do contribuinte".

De acordo com a mencionada autora ${ }^{261}$, a capacidade contributiva pode ser classificada em absoluta ou relativa. A capacidade contributiva absoluta ou objetiva ocorre quando se está perante um fato que constitui uma manifestação de riqueza.

Nesta perspectiva, determina o mencionado comando que o legislador selecione fatos que demonstrem possibilidade para arcar com as despesas públicas, os quais irão indicar a existência de um sujeito passivo em potencial.

A capacidade contributiva absoluta ou objetiva figuraria, a um só tempo, pressuposto ou fundamento do imposto, bem assim vetor para a eleição das hipóteses de incidência deste ${ }^{262}$.

De seu lado, a capacidade contributiva relativa ou subjetiva tem como foco um sujeito individualmente considerado ${ }^{263}$ e requer a aferição da medida da capacidade que ele tem para contribuir diante da incidência tributária.

Portanto, a capacidade contributiva relativa ou subjetiva figura como critério para graduação do imposto, estipulando limites à imposição tributária para que esta não alcance

\footnotetext{
${ }^{259}$ BECKER, Alfredo Augusto. Op. cit., p. 498.

${ }^{260}$ COSTA, Regina Helena. Princípio da capacidade contributiva. São Paulo: Malheiros, 1996. p. 21.

${ }^{261}$ COSTA, Regina Helena. Princípio da capacidade contributiva, cit., p. 26.

262 Id. Ibid., p. 29.

${ }^{263}$ Id. Ibid., p. 26.
} 
a parcela de riqueza mínima, indispensável à sobrevivência do contribuinte, nem produza efeito de confisco ou cerceie outros direitos fundamentais ${ }^{264}$.

Klaus Tipke ${ }^{265}$ defende que a capacidade contributiva consiste na determinação de que todos devem arcar com o ônus tributário de acordo com o importe de sua renda, resguardando-se a parcela correspondente ao mínimo que garante a existência e o cumprimento das obrigações particulares básicas.

De acordo com o entendimento desse autor, considerando que a capacidade econômica pretende que se grave a renda indicativa da capacidade contributiva de modo permanente, a exação não pode provocar o esgotamento da aludida fonte impositiva, ainda que gradualmente ${ }^{266}$.

Do quanto até aqui exposto, verifica-se que o conteúdo e o alcance do princípio da capacidade contributiva não são unívocos, e que algumas das concepções acima alinhavadas guardam proximidade com o comando constitucional insculpido no art. 150, IV, da Lei Maior, que contempla vedação ao confisco tributário.

Nesse sentido, já pontuou Aires Barreto ${ }^{267}$ que a maioria da doutrina, ao definir a acepção do referido dispositivo, restringe-se a aduzir que "é confiscatório o imposto que excede a capacidade contributiva".

Com efeito, é quase unânime o entendimento segundo o qual a tributação que desatende à capacidade contributiva, especialmente no seu aspecto subjetivo, exigindo exação superior à capacidade que o indivíduo possui de arcar com as despesas públicas, produz efeito de confisco.

Nessa perspectiva, muitos doutrinadores ${ }^{268}$ aduzem que a norma que veda o confisco teria fundamento na capacidade contributiva, condicionando a configuração do

\footnotetext{
${ }^{264}$ Id. Ibid., p. 29.

${ }^{265}$ TIKE, Klaus. Moral tributaria del Estado y de los contribuintes. Tradução de Pedro M. Herrera Molina. Madrid: Marcial Pons, 2002. p. 35.

266 TIKE, Klaus. Op. cit., p. 35.

${ }^{267}$ BARRETO, Aires Fernandino. Vedação ao efeito de confisco. Revista de Direito Tributário, v. 64, n. 98 , p. 100, set. 1994.

${ }^{268}$ Esse é o entendimento de Roque Antônio Carrazza, para quem: “[...] o princípio da não confiscariedade deriva do princípio da capacidade contributiva. Realmente, as leis que criam impostos, a levarem em conta a capacidade econômica dos contribuintes, não podem compeli-los a colaborar com gastos públicos além de suas possibilidades. Estamos vendo que é confiscatório o imposto que, por assim dizer, esgota a riqueza tributável das pessoas, isto é, que não leva em conta suas capacidades contributivas" (CARRAZZA, Roque Antonio. Op. cit., p. 70). Na mesma esteira, defende Ives Gandra da Silva Martins: "Não é fácil definir o que é confisco; entendo eu que sempre que a tributação agregada retire a capacidade contributiva de o contribuinte se sustentar e se desenvolver (ganhos para suas necessidades essenciais e ganhos superiores ao
} 
confisco ao esgotamento desta ${ }^{269}$.

A Constituição brasileira de 1988 previu expressamente, no $\S 1 .^{\circ}$ do art. 145, que, sempre que possível, a graduação dos impostos será feita com base na capacidade econômica do contribuinte.

Quanto à menção expressa a impostos, já restou pacificado que a capacidade contributiva deve ser aplicada nas demais espécies tributárias, de acordo com as peculiaridades de cada uma.

No que tange à expressão "sempre que possível", esta provoca mais discussões. Assim é que Ricardo Lobo Torres se posiciona no sentido de que a capacidade contributiva é imperativa e sempre deve haver a busca pela sua aplicação nas mais diversas espécies tributárias. A ressalva foi estipulada em relação aos tributos extrafiscais. Ressalte-se a sua dicção:

A expressão "sempre que possível" permite que a capacidade contributiva e seus subprincípios se ajustem às várias espécies de impostos, mas não admite que deixem de ser aplicados quando isso for possível [...]. De outra parte, a ressalva constitucional visa compatibilizar a capacidade contributiva com a extrafiscalidade. Sempre que possível o legislador observará o princípio da capacidade econômica; mas, em certos casos, a seu prudente critério, poderá utilizar o imposto para atingir objetivos extrafiscais $[\ldots]$.

De sua parte, Fernando Aurelio Zilveti ${ }^{270}$, amparado nas lições de Tipke, sustenta que a extrafiscalidade não guarda relação com o princípio da capacidade contributiva, haja vista que a atividade extrafiscal do Estado busca servir à política intervencionista no domínio privado. De tal modo, quando há elevação da carga tributária incidente sobre o

atendimento destas necessidades para reinvestimento ou desenvolvimento) estar-se-á perante o confisco" (MARTINS, Ives Gandra da Silva et al. Curso de direito tributário. 7. ed. São Paulo: Saraiva, 2000. p. 110).

${ }^{269}$ Em trabalho em que se estudou a vedação ao confisco tributário de que trata o art. 150, VI, da CF, teve-se a oportunidade de explicitar que toda vez que a exação esgota a "capacidade contributiva do sujeito passivo da obrigação tributária, a regra que veda o confisco terá palco, determinando o afastamento da respectiva exação quantitativamente excessiva". Contudo, defende-se, ainda, que existiam situações em relação às quais "o montante exigido a título de tributo não viola a capacidade contributiva do sujeito passivo por ela afetado, mas produz efeito de confisco em virtude da desnecessidade da invasão aos direitos individuais por ela implementada". Nesse sentido, não se pode limitar a conceituação do efeito de confisco ao exaurimento da capacidade contributiva da pessoa física ou jurídica submetida à tributação, sendo necessário investigar as hipóteses em que o tributo é confiscatório, por ser desnecessário, embora ainda persista capacidade para se arcar com o seu custo (BRANDÃO, Renata Figueirêdo. Vedação ao tributo com efeito de confisco. 2007. Dissertação (Mestrado) - Faculdade do Direito, Universidade Federal da Bahia, Salvador, p. 153). Sobre o tema ver HORVATH, Estevão. O princípio do não confisco no direito tributário cit.

${ }^{270}$ ZILVETI, Fernando Aurélio. Op. cit., p. 199-200. 
tabaco e álcool, por exemplo, esta não se justifica pela capacidade contributiva dos consumidores, pois tal medida independe da condição econômica do cidadão alcançado pela norma tributária.

Para o mencionado professor da Fundação Getúlio Vargas, a extrafiscalidade deverá respeitar a propriedade, o livre exercício profissional, a vedação ao confísco, estando, pois, seus limites calcados na "razoabilidade e proporcionalidade, corolários do princípio da igualdade, elementos essenciais para aferir a finalidade dos tributos extrafiscais"271.

Fazendo um contraponto à doutrina que defende a insubmissão do tributo extrafiscal ao primado da capacidade contributiva, Enrico de Mita pondera que a tributação extrafiscal deve respeitar o princípio da capacidade contributiva, "no sentido de que, ainda que sendo preordenada a metas extrafiscais, e mesmo sendo estas metas alcançadas exatamente quando a hipótese de incidência não se verifica, a tributação deve ter como pressuposto um fato economicamente relevante, um fato que constitua manifestação de riqueza”.

Helenilson Cunha Pontes ${ }^{272}$, nessa mesma senda, porém adotando fundamento diverso, aduz que o sistema jurídico deve ser considerado na sua totalidade, pelo que, ainda que se esteja diante de tributação fortemente marcada pela extrafiscalidade, a obrigatoriedade de aplicação da capacidade contributiva é mantida.

Após admitir ser árdua a tarefa de conciliar o princípio da capacidade contributiva com os tributos com fins extrafiscais, citando doutrinadores que tanto admitem tal conciliação quanto outros que a repelem ${ }^{273}$, José Marcos Domingues de Oliveira, referindo-se especificamente à tributação com fins de proteção ambiental, sustenta ser possível a identificação de fatos geradores que revelem, pela apreensão ou aproveitamento de bens naturais, manifestações de riquezas susceptíveis de tributação e que justifiquem

${ }^{271}$ ZILVETI, Fernando Aurélio. Op. cit., p. 200.

${ }^{272}$ PONTES, Helenilson Cunha. O princípio da capacidade contributiva e a extrafiscalidade: uma conciliação possível e necessária. In: SCAFF, Fernando Facury (Coord.). Ordem econômica e social: estudos em homenagem a Ary Brandão de Oliveira. São Paulo: LTr, 1999. p. 153.

${ }^{273}$ Registra José Marcos Domingues de Oliveira o posicionamento do espanhol Rafael Calvo Ortega, para quem "os tributos extrafiscais devem gravar fatos lícitos e que manifestem capacidade econômica". In Curso de derecho financiero. 9. ed. Madrid: Thompson-Civitas, 2005. v. I. Derecho tributario, parte general, p. 142. Em sentido contrário, afastando a obrigatoriedade de conciliação entre a extrafiscalidade e a capacidade contributiva, encontra-se o argentino Giuliani Fonrouge. Derecho financeiro. 7. ed. Buenos Aires: Depalma, 2001. v. 1, p. 35. 
uma ponderada participação dos agentes econômicos no rateio dos custos de manutenção do Estado $^{274}$.

De tudo quanto até aqui exposto, conclui-se que, muito embora o vetor norteador da exação extrafiscal não seja a capacidade contributiva, porquanto o fim precípuo de tal tributação não constitui a arrecadação de recursos financeiros para o erário, a ser implementada de acordo com as condições particulares dos indivíduos, afigura-se imperioso que o tributo extrafiscal incida sobre fatos geradores que revelem riqueza.

Considerando que a imposição extrafiscal está atrelada à concretização de objetivo constitucionalmente tutelado, é aceitável que este venha a restringir a propriedade e a liberdade do contribuinte, contudo, há limites a ser atendidos. Primeiramente, como já dito, a imposição não poderá atingir situações que não indiquem riqueza. Além disso, não poderá amesquinhar excessivamente a propriedade, a liberdade e outros direitos fundamentais, sendo imprescindível a observância à razoabilidade e à proporcionalidade.

Assim, no que concerne à relação entre a capacidade contributiva e a criação de incentivos fiscais, uma vez que ao se instituir um incentivo fiscal haverá tratamento diferenciado a determinado grupo de contribuintes alcançado pela tributação, resta claro que, a rigor, o princípio da capacidade contributiva, no seu aspecto objetivo, estará atendido, porquanto o instituto sob análise ocorrerá apenas quando houver tributação prévia, que, em regra, havia sido instituída sobre um substrato fático revelador de riqueza.

É fundamental pontuar que poderá o grupo contemplado por um incentivo ser dotado de elevada capacidade para contribuir. Tal situação, todavia, não irá macular a norma que introduz o estímulo fiscal, por violação à capacidade contributiva, haja vista que, como já dito, o fim precípuo desta não é arrecadar de acordo com o potencial econômico dos atingidos pela tributação, mas tornar a tributação um instrumento para a efetivação de conduta que não está atrelada à capacidade contributiva de quem a pratica.

Em suma, o incentivo fiscal pressupõe o atendimento do princípio da capacidade contributiva na sua dimensão objetiva, já que irá ocorrer no âmbito da tributação; porém, nem sempre será possível que a graduação da desoneração se paute com base na capacidade contributiva.

\footnotetext{
274 OLIVEIRA, José Marcos Domingues de. Direito tributário e meio ambiente: proporcionalidade,
} tipicidade aberta, afetação da receita. Rio de Janeiro: Renovar, 1995. p. 22. 
É certo que, sempre que for cabível, a norma instituidora do incentivo buscará conjugar o fim constitucional com o princípio da capacidade contributiva. Assim, é possível, mas não determinante, que a redução da alíquota concedida a maquinário mais moderno e competitivo, destinado a setor específico da economia pouco lucrativo, seja maior do que a redução conferida àqueles utilizados por setores mais lucrativos. Tal modulação dependerá da intensidade que o estímulo precisará ter em cada caso, para que se atinja de forma efetiva o respectivo objetivo legal.

\subsubsection{Livre concorrência}

O Estado brasileiro, como já frisado, é um Estado regulador, por estipular políticas econômicas que buscam interferir no mercado de modo a aperfeiçoar o seu livre funcionamento.

A mencionada liberdade de concorrência é um dos pilares do Estado regulador. No contexto desse modelo estatal, tem-se que o princípio da livre concorrência será o vetor responsável por buscar a preservação do equilíbrio concorrencial, mediante o estabelecimento da igualdade de condições entre os agentes que atuam no mesmo mercado.

A liberdade de concorrência demanda a estruturação de condições iguais para os sujeitos econômicos, com um ambiente de lealdade entre eles, que devem desempenhar seus papéis visando a maximizar a riqueza, mas sem manipulações ${ }^{275}$.

No ordenamento jurídico brasileiro ${ }^{276}$, o primado da livre concorrência figura no rol dos princípios da ordem econômica elencados pelo art. 170 da Constituição de 1988, sendo responsável por conformar a atividade econômica pátria, conjuntamente com os demais princípios ali destacados, entre os quais se destacam a defesa do consumidor, a soberania nacional, a propriedade e a defesa do meio ambiente.

Vale ressaltar que os contornos traçados pelos mencionados princípios na ordem econômica devem observar os fundamentos desta, que são a valorização do trabalho e a

\footnotetext{
${ }^{275}$ ELALI, André. Op. cit., p. 102.

${ }^{276}$ No que toca ao Mercosul, o Tratado de Assunção somente previu, de forma genérica, em seu art. 4. ${ }^{\circ}$, que “os Estados-Partes coordenarão suas respectivas políticas nacionais com o objetivo de elaborar normas comuns sobre concorrência comercial". Tal previsão é tida como fundamento do Protocolo de Defesa da Concorrência do Mercosul (Protocolo de Fortaleza), de 1996. Cabe assinalar, todavia, que esse protocolo não alcançou, pelo menos até o momento, o resultado esperado.
} 
livre-iniciativa. Ademais, tais delineamentos não podem descurar do seu objetivo "de assegurar a todos a existência digna, conforme os ditames da justiça social”.

Com efeito, da análise do contexto em que a livre concorrência se encontra inserida na Carta Política, verifica-se que a sua interpretação deverá ser efetuada em harmonia com os fundamentos, valores e objetivos da ordem econômica.

Nesse cenário de amplo entrelaçamento de diretrizes, cumpre, inicialmente, a distinção entre o princípio da livre concorrência e o princípio da livre-iniciativa, bastante confundidos entre si.

Deveras, o princípio da livre-iniciativa é concebido como aquele que irá permitir ao particular a atuação no domínio econômico, sem obstáculos impostos pelo Poder Público. Trata-se, pois, da liberdade para a realização das atividades econômicas.

Ao longo do texto constitucional, foram estipulados princípios e regras vinculados à liberdade no âmbito do domínio econômico. De tal forma, previu-se a livre escolha da profissão (art. $5^{\circ}$, XIII: “é livre o exercício de qualquer trabalho, ofício ou profíssão, atendidas as qualificações profissionais que a lei estabelecer"); bem assim o livre exercício das atividades econômicas em geral (art. 170, parágrafo único: "é assegurado a todos o livre exercício de qualquer atividade econômica, independente de autorização de órgãos públicos, salvo nos casos previstos em lei”).

Considerando que a livre-iniciativa se encontra vinculada à atividade econômica sem imposição de limites injustificados ao seu exercício (só as restrições cabíveis postas em lei) e que a livre concorrência se relaciona à igualdade de condições entre os competidores de um mesmo mercado, constata-se que é possível existir livre-iniciativa ainda que inexista livre concorrência, não se podendo falar em livre concorrência sem a livre-iniciativa.

Ana Maria $\operatorname{Nusdeo}^{277}$ elucida a distinção entre a livre concorrência e a livre iniciativa, nos termos abaixo reproduzidos:

O princípio da livre iniciativa é fundamento da República e da Ordem Econômica no contexto constitucional brasileiro. Relaciona-se ao princípio da livre concorrência, mas não é a ele equivalente. O princípio da livre iniciativa tem a ver com a manutenção das possibilidades reais de acesso e exercício de atividade econômica pelos indivíduos, como garantia de sua liberdade econômica. O princípio da livre concorrência

\footnotetext{
277 NUSDEO, Ana Maria de Oliveira. Defesa da concorrência e globalização econômica (o controle da concentração de empresas). São Paulo: Malheiros, 2002. p. 234.
} 
refere-se às possibilidades desses agentes de disputarem as preferências do consumidor no mercado e às medidas de salvaguarda a um tipo de mercado que assim o permita.

Fincada tal distinção preliminar, cumpre avançar no exame do conteúdo do princípio da livre concorrência, cabendo, de logo, esclarecer que, quando se afirmou acima que este primado visa à igualdade de condições entre os agentes de um mesmo mercado, a igualdade a que se fazia alusão seria a relativa à oportunidade de competir no mercado.

Não foi por outra razão que a Lei Maior, conferindo concretude à livre concorrência, cunhou regra que impõe igualdade de regimes jurídicos entre o particular e o Estado, quando estiverem atuando no domínio econômico, sujeitando-os às mesmas imposições legais, inclusive tributárias. Com efeito, o $§ 1 .^{\circ}$ do artigo 173 da Carta política, ao tratar da exploração direta da atividade econômica pelo Estado, estabelece que esta deve se sujeitar ao regime jurídico próprio das empresas privadas, inclusive quanto aos direitos e obrigações tributárias.

A multicitada ideia de igualdade presente no princípio da livre concorrência também pode ser extraída da norma que proíbe a introdução de tributos que discriminam unidades da Federação, ou que limitam o trânsito de pessoas e bens (art. 150, V).

Note-se, contudo, que tal busca pela igualdade de condições competitivas não se confunde com a busca pela igualdade entre competidores, porquanto estes irão perseguir a sua diferenciação dos demais agentes para ampliar o seu mercado, ou seja, lutarão, exatamente, para obter destaque em relação aos demais.

Portanto, faz parte da lógica do próprio mercado que os agentes com atuação no domínio econômico persigam uma vantagem competitiva em relação aos demais e, por consequência, busquem o poder econômico.

Atento a essa questão, Eros Roberto Grau ${ }^{278}$ esclarece que o poder econômico não só é previsto, mas admitido pelo ordenamento jurídico pátrio, desde que não haja abusos no seu exercício. Assim, não é tolerada a tentativa de dominação de mercados, a eliminação da concorrência ou o aumento arbitrário de lucros.

${ }^{278}$ GRAU, Eros Roberto. A ordem econômica na Constituição de 1988, cit., p. 300. 
Neste compasso, o referido autor aduz inexistir oposição entre o princípio da livre concorrência e o princípio da repressão aos abusos do poder econômico, extraído do $\S 4 .^{\circ}$ do art. 173 da Lei Maior, sendo, em verdade, o último, fragmento do primeiro.

Com efeito, a tolerância à aquisição de mercado por força da eficiência do competidor encontra-se estampada na norma extraída do art. $20, \S 1 .^{\circ}$, da Lei n. ${ }^{\circ}$ $8.884 / 1994$, segundo a qual "a conquista de mercado resultante de processo natural fundado na maior eficiência de agente econômico em relação a seus competidores não caracteriza ilícito previsto no inciso II", pois o aludido inciso II repele a ação para dominar mercado relevante de bens e de serviços.

Assim sendo, o Direito pátrio autoriza que um agente sobrepuje os demais num dado mercado relevante, na hipótese de este exercer suas atividades de modo eficiente, em consonância com as normas aplicáveis. Assim, é legítima a luta pela conquista de mercado, desde que a competição entre os agentes se mantenha nos limites da legalidade.

A referida competição, a rigor, traz consigo a melhoria dos produtos e dos serviços, a redução dos preços, dentre outros benefícios para a sociedade.

Portanto, só é vedado que certo agente vença a disputa se tal vitória for alcançada por intermédio de meios não permitidos pelo sistema jurídico, tais como a criação de cartéis e a prática de preços extorsivos.

Luís Eduardo Schoueri ${ }^{279}$ extrai do conteúdo do art. 219 da Lei Maior, segundo o qual “o mercado interno integra o patrimônio nacional e será incentivado de modo a viabilizar o desenvolvimento cultural e socioeconômico, o bem-estar da população e a autonomia tecnológica”, a conclusão de que o princípio da livre concorrência tem relação com a própria existência do mercado.

Segundo o aludido jurista ${ }^{280}$, o mandamento de incentivo ao mercado interno tem respaldo em tal dispositivo constitucional e, por sua vez, a garantia da livre concorrência estaria relacionada à intervenção econômica do Estado para a correção de falhas do mercado.

Deveras, visa o primado da livre concorrência a promover a igualdade de condições entre os competidores, determinando a equalização dos desequilíbrios identificados.

\footnotetext{
${ }^{279}$ SCHOUERI, Luís Eduardo. Normas tributárias indutoras e intervenção econômica, cit., p. 94.

${ }^{280}$ Id., loc. cit.
} 
$\mathrm{Na}$ tentativa de conferir igualdade de condições de competir àqueles que atuam no mercado, o ente estatal buscará concretizar o princípio da neutralidade concorrencial, segundo o qual o Estado deve abster-se de atuar como um agente causador de distorções concorrenciais.

Tendo em vista os objetivos constitucionais, vetores e fundamentos da própria ordem econômica, resta evidente que o princípio da livre concorrência não busca um equilíbrio econômico por si só, que se volte à eficiência econômica meramente alocativa; pelo contrário, seu escopo é um estado de equilíbrio que sirva, segundo os ditames da Constituição, de instrumento para o alcance de bens maiores e, em especial, assegurar a todos existência digna, consoante os valores da justiça social e com fundamento na valorização do trabalho e na livre-iniciativa ${ }^{281}$.

Neste contexto, haverá situações em que outros objetivos constitucionais irão autorizar que o princípio da livre concorrência, representado pela neutralidade concorrencial do Estado e pela neutralidade tributária, seja relativizado, ocorrendo certa desigualdade de condições entre dois concorrentes.

A referida desigualdade é tolerada pelo sistema desde que não seja de tal ordem que prejudique desproporcionalmente os demais princípios, dentre eles a livre- iniciativa. De fato, o ponto fulcral é saber em que contexto e em que medida essa distinção de condições entre competidores do mesmo setor do mercado é admitida, cabendo ponderações com base na proporcionalidade.

Portanto, a livre concorrência não irá demandar a igualdade absoluta entre os competidores, podendo haver desigualdade em virtude da preponderância de outro fim constitucional.

\footnotetext{
${ }^{281}$ BRAZUNA, José Luis Ribeiro. Defesa da concorrência e tributação: à luz do art. 146-A da Constituição. São Paulo: Quartier Latin, 2009. p. 77-78. (Série Doutrina tributária, v. 2.) O citado autor menciona entendimentos de diversos juristas que defendem a mesma posição acima indicada: "Leandro Alexi Franco, para quem a concorrência é instrumento e objetivo de política econômica para o crescimento e desenvolvimento econômico e social do país; Luis Fernando Schuartz, que afirma não ser a concorrência um fim em si mesmo, mas um meio para a obtenção de um resultado final abstratamente definido em nossa ordem econômica constitucional, qual seja o 'bem de todos'; Sérgio Varella Bruna, que fala em uma 'concorrência desejável', ou seja, uma concorrência que proporcione o maior ganho social possível, mesmo que isso represente a existência de pouca ou de nenhuma concorrência em determinado mercado, sendo preciso sempre valorar os interesses sacrificados, devendo ser eles menores do que os interesses atingidos; e Carlos Jacques Gomes, que afirma que as normas destinadas a corrigir falhas de mercado devem também se inspirar nos objetivos e valores (liberais e intervencionistas) da Constituição Federal, de maneira tal que o direito acabe distorcendo os mecanismos de mercado, com o objetivo de promover justiça social".
} 
A ordem jurídica posta pelo legislador constituinte de 1988 não é neutra, demandando que o ente estatal promova o desenvolvimento econômico nacional afinado com o desenvolvimento humano. As normas tributárias, de igual modo, não devem ser neutras, sendo necessária a instituição de tributos que intervenham nos campos social e econômico, visando à redistribuição e ao equilíbrio.

Nesse sentido, quando se faz alusão à neutralidade tributária, inserida no âmbito da neutralidade da atuação estatal, não se faz menção a tributo desprovido de efeitos sobre o domínio econômico, figurando como elemento inexpressivo na tomada de decisão daqueles que exercem atividades no mercado. É que a tributação diz de perto com o princípio da livre concorrência, dentre ouras razões, por conta de os tributos, inegavelmente, representarem um custo para os agentes econômicos, podendo gerar desequilíbrios concorrenciais ${ }^{282}$.

Isso sem mencionar o fato de que tal concepção, de cunho absolutamente liberal, afigura-se incompatível com a Lei Maior, que estabeleceu um Estado Social e Democrático de Direito, em que a tributação busca efetivar a justiça distributiva, bem como realizar os mais diversos fins sociais e econômicos.

Assim sendo, a neutralidade tributária não pode ser entendida, no ordenamento jurídico brasileiro, como uma proibição à interferência da tributação no domínio econômico, mas como vetor que determina que a imposição tributária não deve ser responsável por distorções no mercado.

Com efeito, num cenário de ampla aplicação da extrafiscalidade, certo é que a neutralidade tributária deve ser concebida dentro de um contexto de interação com os demais valores, bens e princípios da ordem econômica e social, sendo admitida e desejada a atuação estatal efetivada com instrumental tributário, voltada a corrigir as falhas de mercado e a realizar os demais objetivos juridicamente tutelados.

Nessa perspectiva, Ricardo Seibel de Freitas Lima ${ }^{283}$, ao analisar o conteúdo e alcance da neutralidade tributária, defende que esta, em primeiro plano, pode ser concebida como um dever negativo ou de omissão, consistente na não interferência na concorrência por meio da tributação.

\footnotetext{
${ }^{282}$ BOMFIM, Diego. Tributação e livre concorrência. São Paulo: Saraiva, 2011. p. 242.

283 LIMA, Ricardo Seibel de Freitas. Livre concorrência e dever de neutralidade tributária. 2005. Dissertação (Mestrado) - Faculdade de Direito da Universidade Federal do Rio Grande do Sul, Porto Alegre, p. 90 .
} 
Contudo, ressalta o citado autor que, em segundo plano, deve ser compreendida como “dever positivo ou de ação, de prevenir ou restaurar, quando o for o caso, a igualdade de condições na concorrência, quando esta se encontre ameaçada por ações de particulares ou outros fatores relevantes, sempre objetivando a preservação da igualdade de condições competitivas no mercado".

Dessa forma, quando o tributo se volta, predominantemente, ao fim de arrecadar fundos para o Estado, tal vetor irá determinar que a tributação seja suficiente para o abastecimento do erário, sem, contundo, atingir as atividades do particular a ponto de interferir em sua competitividade, prejudicando-o sob o aspecto concorrencial.

Acerca da limitação ora em debate, posiciona-se Diego Bomfim ${ }^{284}$, asseverando que, em sede de "tributação funcionalmente identificada com a fiscalidade, o princípio da livre concorrência se manifesta mediante um dever de neutralidade concorrencial do Estado ante a tributação (neutralidade tributária), entendido como uma regra jurídica que garante aos concorrentes uma igualdade de tratamento tributário e, como consequência, a preservação da concorrência”.

Fazendo um contraponto entre tal limite e aquele imposto quando se trata de tributo com fins, primordialmente, extrafiscais, o mencionado autor defende:

Diversamente, na tributação voltada à concretização de induções comportamentais, o princípio da livre concorrência não se manifesta mediante o dever de neutralidade, mas como um dos princípios jurídicos que serão levados em consideração quando da instituição ou majoração do tributo e, ainda, em eventual revisão judicial. A existência de normas tributárias indutoras, seja pela técnica do agravamento ou de incentivos, pressupõe, pelo menos potencialmente, a discriminação de pessoas, atividades ou bens em função do objetivo almejado, impossibilitando a existência de uma neutralidade tributária. Na expressão de Fernando Zilveti, "a indução é a antítese da neutralidade".

[...] Na tributação extrafiscal, o princípio da livre concorrência não será alcançado pela via da neutralidade tributária, já que pressuposto o tratamento tributário desigual (seja por agravamentos ou incentivos), e sim pela admissão de sopesamento do próprio princípio da livre concorrência com os demais princípios constitucionais utilizados na fundamentação da extrafiscalidade.

De modo lapidar, José Luiz Ribeiro Brazuna aduz ${ }^{285}$ que, "quando se entende a neutralidade tributária sob o enfoque da ausência de efeitos contrários à livre concorrência,

${ }^{284}$ BOMFIM, Diego. Op. cit., p. 198.
${ }^{285}$ BRAZUNA, José Luis Ribeiro. Op. cit., p. 77. 
percebe-se que se trata de princípio coerente com a realidade de indução e extrafiscalidade impregnada no texto constitucional".

Defende Humberto Ávila ${ }^{286}$ que a neutralidade da tributação refere-se ao não exercício da "influência imotivada" na atividade dos contribuintes, correspondendo, pois, a uma "manifestação estipulada da própria igualdade na sua conexão com o princípio da liberdade de concorrência, notadamente no aspecto negativo da atuação estatal". Assim, o dever de neutralidade é elemento em prol da concorrência, e acaba por assegurar a igualdade de oportunidades no mercado.

Tecidas as ponderações vertentes, conclui-se, na linha do quanto sustentado por Humberto Ávila, que a neutralidade tributária deve ser concebida como uma expressão da igualdade, a qual determina que a imposição tributária não pode ser instituída de modo a prejudicar a concorrência.

Vale notar, todavia, que tanto na tributação com fins predominantemente fiscais quanto na tributação com fins extrafiscais, a análise da neutralidade deve ser feita à luz dos demais valores constitucionais, ainda que em medidas diferentes. Isto porque descabe exigir efeitos eminentemente neutros da tributação, ainda que se trate de imposição com o intuito de arrecadar recursos financeiros aos cofres públicos, já que as imposições tributárias, invariavelmente, alteram o status quo, influenciando o consumo, a produção, a circulação, o rendimento, o patrimônio etc.

Com base em tais premissas, e adotadas as devidas cautelas na interpretação e aplicação da neutralidade tributária, cumpre registrar os preceitos constitucionais que conformam normas tributárias indutoras voltadas à regulação do mercado, a saber: i) as hipóteses em que o constituinte afasta o princípio da anterioridade (art. 150, III, "b" e "c", c/c $153, \S 1 .^{\circ}$ ) e ii) quando a legalidade tributária é mitigada (art. 150, I c/c 153, § 1. ${ }^{\circ}$ ), para permitir que o Poder Executivo altere alíquotas dos impostos aduaneiros, do Imposto sobre Produtos Industrializados e do Imposto sobre Operações de Crédito, Câmbio, Seguros, Títulos e Valores Mobiliários ${ }^{287}$.

Destaque especial deve ser conferido ao art. 146-A, introduzido no texto da Lei Maior pela Emenda Constitucional n. ${ }^{\circ} 42 / 2003$. Tal dispositivo autorizou que o legislador

\footnotetext{
${ }^{286}$ ÁVILA, Humberto. Teoria da igualdade tributária, cit., p. 162.

${ }^{287}$ SCHOUERI, Luís Eduardo. Normas tributárias indutoras e intervenção econômica, cit., p. 94-95.
} 
interviesse sobre o domínio econômico, com o objetivo de inibir os desequilíbrios concorrenciais, por meio de "estabelecimento de critérios especiais de tributação".

Deveras, criou-se autorização para que a lei complementar estipulasse critérios especiais de tributação, com o escopo de prevenir desequilíbrios da concorrência.

Luís Eduardo Schoueri ${ }^{288}$ sustenta que a inovação que pode ser atribuída ao multicitado preceito constitucional consiste na introdução de autorização para que o legislador infraconstitucional possa criar normas tributárias indutoras com o objetivo de prevenir os distúrbios concorrenciais "provocados", pois aqueles de ordem estrutural já estariam passíveis, antes da Emenda, de ser objeto de norma tributária indutora.

José Luis Ribeiro Brazuna ${ }^{289}$, por seu turno, defende que o art. 146-A "veicula, de forma explícita, uma norma de competência que autoriza o legislador infraconstitucional a manipular os critérios da norma de incidência tributária com o objetivo de, criando regimes mais ou menos gravosos de tributação, gerar efeitos indutores de comportamento dos agentes econômicos".

No entender do mencionado autor, os critérios a ser desenvolvidos teriam como escopo a prevenção de desequilíbrios concorrenciais que possam vir a ser gerados tanto por falhas estruturantes quanto pela deslealdade de comportamentos.

De sua parte, posicionando-se de modo mais restritivo quanto ao alcance do art. 146-A, Diego Bomfim ${ }^{290}$ ressalta que a nova competência outorgada pela Carta Política para instituição de critérios especiais de tributação deve atuar no sentido de obstar que a própria tributação seja um fator de desequilíbrio concorrencial.

Segundo o mencionado jurista ${ }^{291}$, o multicitado dispositivo não confere permissão para "correções, pela tributação, de falhas mercadológicas, triviais e esperadas em um contexto de assunção de inexistência de concorrência perfeita", haja vista que os instrumentos oferecidos pela lei de defesa da concorrência, em comparação com a tributação, seriam completamente suficientes e mais eficazes na prevenção e repressão dos distúrbios de mercados, relacionados à concorrência.

Forte no entendimento de que os critérios especiais de tributação se prestam a prevenir que o exercício da competência tributária represente elemento de desequilíbrio

\footnotetext{
${ }^{288}$ SCHOUERI, Luís Eduardo. Normas tributárias indutoras e intervenção econômica, cit., p. 251-253.

${ }^{289}$ BRAZUNA, José Luis Ribeiro. Op. cit., p. 140-141.

${ }^{290}$ BOMFIM, Diego. Op. cit., p. 194.

${ }^{291}$ Id., loc. cit.
} 
concorrencial, Diego Bomfim ${ }^{292}$ traz exemplos que ilustram o alcance, no seu entender, dos mencionados critérios:

Esses critérios poderão prever a instituição de obrigações acessórias mais rígidas e setoriais, a fixação de critérios de verificação da neutralidade tributária no exercício da competência tributária por oneração fiscal, a criação de regras para implantação de regimes não cumulativos tendentes a não gerar distorções concorrenciais, critérios gerais de observância obrigatória quando do exercício da competência tributária por exoneração (como criação de regras de revisão dos incentivos fiscais em prazos certos e periódicos), regras sobre edição de parcelamentos especiais cumulados com anistias, balizas normativas para a concessão de regimes especiais de tributação, enfim, o estabelecimento de normas gerais que tenham o condão de impor aos detentores de competência tributária uma atuação não fomentadora de distúrbios (exógenos) sobre a livre concorrência.

Em que pese o bem fundamentado posicionamento do aludido autor, o fato é que o art. 146-A da Constituição Federal, pelo princípio da máxima efetividade da constituição, não deve ter seu conteúdo limitado, estando o estudo em foco alinhado ao posicionamento mais amplo adotado por Luís Eduardo Schoueri e José Luis Ribeiro Brazuna. A esse respeito, vale ressaltar, inclusive, a existência de diversos projetos de lei complementar nos quais há previsão de critérios especiais de tributação, que pretendem evitar desequilíbrios da concorrência gerados por falhas de mercado.

Pela pertinência com o objeto do presente trabalho, ressalte-se o Projeto n. ${ }^{o}$ $73 / 2007^{293}$, de autoria dos deputados federais Antonio Carlos Mendes Tham (PSDB/SP) e Luiz Carlos Hauly (PSDB/PR), que tem como fundamento o art. 146-A da Lei Maior e busca criar critérios tributários que previnam os desequilíbrios da concorrência decorrentes das externalidades relacionadas à poluição ambiental.

Consoante já abordado acima ${ }^{294}$, as atividades econômicas podem gerar externalidades responsáveis pela geração de custos ou benefícios decorrentes de tais

\footnotetext{
292 BOMFIM, Diego. Op. cit., p. 194.

293 Projeto de Lei Complementar n. ${ }^{\circ}$ 73/2007. BRASIL. Câmara dos Deputados. Projeto de Lei Complementar PLC 73/2007. Brasil. Câmara dos Deputados. Projeto de Lei Complementar PLC 73/2007. Propõe uma Reformulação Tributária Ecológica, a fím de regulamentar o artigo 146-A, da Constituição Federal, instituir os princípios da essencialidade e do diferencial tributário pela sustentabilidade ambiental e oneração das emissões de gases de efeito estufa, e criar a taxação sobre o carbono (carbon tax), na forma de Contribuição de Intervenção no Domínio Econômico, para a sustentabilidade ambiental e a mitigação do aquecimento global. Disponível em: $<$ http://www.camara.gov.br/proposicoesWeb/fichadetramitacao?idProposicao=354998>. Acesso em: 3 jan. 2012.

${ }^{294}$ Vide item 1.6.3.
} 
atividades, não arcados/auferidos por quem as produz, resultando, assim, em falha de mercado.

O Projeto de Lei Complementar n. ${ }^{o}$ 73/2007 objetiva, sobretudo, a caracterização da essencialidade de produtos com base nos impactos ambientais decorrentes dos respectivos ciclos produtivos, estabelecendo redução da carga tributária para os bens que, na sua produção, uso ou consumo, apresentem balanço de emissões de gases de efeito estufa mais favorável que seus concorrentes, ou que causem menor degradação ambiental, em razão de procedimentos produtivos empregados e insumos utilizados.

Além disso, onera as emissões de gases que intensificam o efeito estufa durante os processos produtivos de bens e serviços, instituindo uma CIDE cujos recursos arrecadados deverão ser aplicados, exclusivamente, para financiamento de projetos de inovação tecnológica em energia renovável e relativos a sequestro de gases de efeito estufa.

Ao analisar o projeto em questão, José Luis Ribeiro Brazuna ${ }^{295}$, com o foco nas desonerações, defende que norma tributária desse tipo estaria apta a alcançar o efeito indutor desejado, podendo ter guarida no art. 146-A, bem como na segunda parte do inciso VI do artigo 170, que permite o "tratamento diferenciado conforme o impacto ambiental dos produtos e serviços e de seus processos de elaboração e prestação".

O referido jurista identificou fragilidade na redação do projeto inicial, no tocante à falta de precisão quanto à identificação dos tributos que poderiam veicular a norma de indução. Isto porque uma proposta de redução de alíquota destinada a tributos de competência dos Estados, do Distrito Federal ou dos Municípios pode levar a discussões em torno da constitucionalidade da norma, haja vista que juristas de escol, tal como Roque Carrazza, defendem que o uso de lei complementar para interferir nas alíquotas instituídas pelos entes diversos da União não encontra amparo legal no art. 146, III, alínea "a", da Carta Política ${ }^{296}$.

Outra inconstitucionalidade repousaria no parágrafo único do art. $2 .^{\circ}$, haja vista que, ao arrepio da divisão de competência posta pelo constituinte, seria autorizado ao Senado Federal instituir alíquotas a serem manejadas pelos Estados e pelo Distrito Federal, em hipóteses diversas daquelas previstas pelo art. $155, \S 2 .^{\circ}$, inciso $\mathrm{V}$, alíneas "a" e "b"297.

\footnotetext{
${ }^{295}$ BRAZUNA, José Luis Ribeiro. Op. cit., p. 222.

${ }^{296}$ Id., loc. cit.

${ }^{297}$ BRAZUNA, José Luis Ribeiro. Op. cit., p. 222-223.
} 
Não há reparos às críticas acima mencionadas, nem à tentativa de se criar lei complementar que pretende veicular critérios tributários a inibir os desequilíbrios concorrenciais gerados por externalidades atreladas às atividades que impactam o meio ambiente.

De fato, a lei complementar em apreço contempla algumas fragilidades - aqui não estudadas -, porém representa louvável tentativa de construção de uma tributação atenta às distorções que as externalidades provocam à economia e à livre concorrência, em total consonância com o art. 146-A da Lei Maior.

Feitas tais considerações acerca dos dispositivos constitucionais e veículos legislativos que conferem concretude à livre concorrência, cumpre pontuar os limites que tal dispositivo impõe em relação aos incentivos fiscais.

Primeiramente, já restou firmado que a simples alegação de tratamento tributário diferenciado não é apta a ensejar a violação ao princípio da livre concorrência, considerando que, no âmbito da extrafiscalidade, a neutralidade tributária adquire contornos mais amplos, de forma que somente será responsável por violar tal princípio a exação ou desoneração que não tiver meios de ser compatibilizada, à luz da proporcionalidade, com os demais princípios consagrados na Carta Política.

Nesse sentido, o tratamento diferenciado instituído pelo incentivo fiscal não transgride, de plano, a livre concorrência, sendo imperioso que, a par das diferenças entre competidores, seja analisado se a desoneração veiculada é condizente com o cenário fático e jurídico do mercado, não gerando distorções.

A ofensa ao referido primado pode ser investigada concretamente, situação em que se verificará se determinado estímulo fiscal, muito embora esteja em consonância com o princípio da igualdade, legalidade etc., afigura-se inconstitucional por causar prejuízos à livre concorrência.

Com efeito, tomando como exemplo os incentivos fiscais relativos ao ICMS concedidos pelos Estados, em especial os menos desenvolvidos das regiões Norte, Nordeste e Centro-Oeste, para atrair investimentos, verifica-se que o objetivo que se busca alcançar encontra respaldo na Constituição (art. 3. ${ }^{\circ}$, inciso III, art. 151, inciso I, art. 165, § 7..$^{\circ}$ e art. 170, inciso VII), a impor a redução das desigualdades regionais ${ }^{298}$.

\footnotetext{
${ }^{298}$ Uma vez que se busca analisar os incentivos fiscais à luz da livre concorrência, não se adentra, aqui, no questionamento acerca da legalidade e constitucionalidade de tais incentivos, concedidos sem amparo em
} 
Vale ressaltar que tais Estados possuem infraestrutura precária, incorrendo em altos custos com logística para fornecer aos principais centros consumidores situados no Sudeste (os custos com fretes, por exemplo, oscilam entre 3\% e $6 \%$ do valor total das mercadorias originárias desses Estados) e, ainda, dispõem de mão de obra pouco especializada, pelo que se afigura evidente o seu déficit de competitividade em comparação com outros Estados do Sudeste em que tais fatores não afetam de forma tão negativa os investidores.

Assim, diante de uma inquestionável distinção entre estágios de desenvolvimento dos Estados brasileiros, a tributação abrandada para aqueles que se instalam nas citadas regiões mais distantes e de reduzido desenvolvimento social e econômico, longe de violar a igualdade, conduz à atenuação de diferenças entre os Estados da Federação, de forma a concretizar o princípio da isonomia.

Sob tal prisma, então, tais incentivos são positivos no seu papel de equilibrar o desenvolvimento do país, trazendo inegáveis ganhos sociais e econômicos para os Estados que atraem investimentos, empregos, formação profissional etc.

No tocante à questão concorrencial, é necessário identificar se o tratamento tributário diferenciado, conferido pelos mencionados Estados menos desenvolvidos, não implica distúrbios concorrenciais.

É lícito que o estímulo fiscal traga vantagem competitiva a atrair empresas de um setor a um Estado, entretanto, a mencionada vantagem não pode ser de tal monta que inviabilize o desenvolvimento de certa atividade em outro Estado, obstaculizando a livre concorrência.

Portanto, incentivos fiscais que distorcem a livre competição no mercado, prejudicando empresas eficientes e produtivas que não gozam dos respectivos benefícios, não devem ser mantidos, sob pena de violação não só à livre concorrência e à livreiniciativa, mas à propriedade, à liberdade, dentre outros princípios e direitos assegurados pela Lei Maior.

Neste contexto, ainda que o incentivo fiscal esteja em total conformidade com os requisitos legais e busque concretizar fim juridicamente relevante, que atenda à isonomia, deverá ser rechaçado caso gere impactos desmedidos à livre concorrência.

convênio, tal como exigido pelo art. 155, XII, $g$, da Constituição Federal de 1988 e pelos dispositivos constantes da Lei Complementar n. ${ }^{\circ}$ 24/1975. 


\subsubsection{Renúncia de Receita}

A análise da concessão de incentivos fiscais deve estar acompanhada da mensuração dos efeitos financeiros dela decorrentes, haja vista que, quando o Estado abstém-se de receber parcela da receita que lhe seria devida para estimular determinada atividade de interesse econômico ou concretizar outro fim juridicamente tutelado, realiza um gasto indireto, que deverá ser quantificado para viabilizar a adequada avaliação do incentivo e a manutenção do equilíbrio orçamentário.

Com efeito, o ato de renunciar à receita pública consubstancia uma política de governo que visa à realização de objetivos de incumbência dos entes políticos: federal, estadual e municipal. Tal prática é amplamente manejada em diversos países do mundo, sem distinções de nível de desenvolvimento econômico-social e de regime de governo ${ }^{299}$.

O instituto da renúncia de receita é de grande relevância, pois corresponde ao montante que o erário deixou de receber em prol de um fim público. Representa a quantificação estimada da diminuição da sua receita, cuja origem decorre da criação de um benefício fiscal/incentivo fiscal num determinado período de tempo.

A sua identificação possibilita um aprimoramento do controle das políticas públicas, já que, quando é estipulado o valor despendido pela instituição de um tratamento tributário mais benéfico, o exame acerca da sua adequação aos propósitos para os quais foi instituído fica muito mais palpável e factível.

A quantificação da receita renunciada promove maior transparência orçamentária, uma vez que possibilita a comparação no orçamento entre o valor que é destinado diretamente para um setor (via subvenção) e a quantia que é transferida indiretamente (via incentivo fiscal) a outro setor. De tal forma, não passará despercebido o fato de um gasto direto com educação ser muito inferior àquele que está sendo destinado, via renúncia fiscal, a uma atividade secundária para o ordenamento jurídico pátrio. A esse respeito, manifestou-se Francisco Carlos Ribeiro ${ }^{300}$ :

A análise de gastos tributários, ao explicitar e quantificar um importante segmento dos gastos públicos, permite que se questione se efetivamente existe o desejo de se assistir financeiramente determinado setor e, caso

\footnotetext{
299 ALMEIDA, Francisco Carlos Ribeiro. A renúncia de receita como fonte alternativa de recursos orçamentários. Revista do Tribunal de Contas do Estado de Minas Gerais, Belo Horizonte, v. 41, n. 4, p. 77-78, out.-dez. 2001.

${ }^{300}$ ALMEIDA, Francisco Carlos Ribeiro. A renúncia de receita... cit., p. 94.
} 
positivo, em que montante. Pode-se questionar se um programa está funcionando, bem como se os custos se comparam com os benefícios esperados, ou ainda se está atingindo seus objetivos, que aliás devem ser claramente delimitados. Pode-se questionar quem efetivamente está se beneficiando daquele programa ou se a assistência financeira proporcionada é suficiente ou não.

Nesta perspectiva, a quantificação dos recursos destinados no orçamento a um determinado setor da economia, por exemplo, não irá revelar o montante que efetivamente lhe foi concedido caso não seja computada a quantia proveniente de incentivos fiscais.

Ressalte-se que a expressão gasto tributário, que é a tradução do inglês de tax expenditure, vem sendo mais utilizada pela doutrina nacional especializada para designar a renúncia de receita. Elcio Fiori Henriques optou pela referida expressão por considerá-la dotada de maior precisão.

O referido autor, depois de defender que o gasto tributário possui caráter estritamente orçamentário, cujo objetivo é a instituição de controles financeiros sobre os efeitos dos benefícios fiscais/incentivos fiscais, tornando-os comparáveis com as despesas diretas, define o instituto como "o enunciado quantitativo, de caráter estritamente orçamentário, do valor estimado da redução da receita pública ocasionada por um benefício fiscal em um determinado intervalo de tempo".

Consoante se passa a abordar, no Brasil o regime jurídico da renúncia de receita demanda que os dispêndios decorrentes da concessão de benefícios e incentivos fiscais ${ }^{301}$ tenham seus montantes estimados na lei orçamentária ou que se realizem compensações, por meio do aumento de tributo.

A Constituição Federal deu o primeiro passo na introdução do referido regime. De fato, ante a patente necessidade de se ter quantificados e controlados os gastos tributários, a Lei Maior determinou, por meio do art. $165, \S 6 .^{\circ}$, que “o Projeto de Lei Orçamentária será acompanhado de demonstrativo regionalizado do efeito, sobre as receitas e despesas, decorrente de isenções, anistias, remissões, subsídios e benefícios de natureza financeira, tributária e creditícia".

\footnotetext{
${ }^{301}$ A renúncia de receita refere-se à quantificação do montante que se deixou de arrecadar, não só em função dos incentivos fiscais concedidos, abrangendo a todos os benefícios fiscais criados, independentemente de ter como escopo o estímulo a condutas. Basta que o ente político tenha deixado de cobrar tributo em favor de determinado grupo ou situação antes atingidos pela imposição tributária, reportando-se, assim, a quantia que ingressaria aos cofres públicos e que deixou de ingressar em face de isenção, redução de base de cálculo, crédito presumido etc.
} 
Desse modo, o referido comando constitucional ressaltou no ordenamento jurídico pátrio a necessidade de se anexar ao Projeto de Lei Orçamentária demonstrativo de benefícios tributários, viabilizando, assim, a identificação, ainda que estimada, do montante despendido por meio de benefícios fiscais, financeiros e creditícios ${ }^{302}$.

Sob a égide de tal ditame constitucional, a Lei Rouanet (Lei n. $\left.{ }^{\circ} 8.313 / 1991\right)$, tendo admitido que pessoas físicas e jurídicas (tributadas com base no lucro real) deduzissem do Imposto de Renda devido parcela dos valores objeto de doação ou de patrocínio a projetos culturais aprovados (art. 26), determinou expressamente o envio ao Congresso de documento contendo a estimativa de valores renunciados, nos seguintes termos:

Art. 37. O Poder Executivo, a fim de atender ao disposto no art. $26, \S 2 .^{\circ}$, desta Lei, adequando-o às disposições da Lei de Diretrizes Orçamentárias, enviará, no prazo de 30 dias, Mensagem ao Congresso Nacional, estabelecendo o total da renúncia fiscal e correspondente cancelamento de despesas orçamentárias.

Nesse compasso, foi editada a Lei Complementar n. ${ }^{\circ} 101 / 2000$, cunhada com o escopo de estabelecer normas de finanças públicas voltadas à salvaguarda da responsabilidade na gestão fiscal. O diploma legal em foco, conhecido como Lei de Responsabilidade Fiscal, avançou no que tange à transparência dos valores de receita renunciados por força da criação de incentivos fiscais/benefícios fiscais, ao albergar novas exigências que evidenciam a necessidade de dimensionamento e equilíbrio dos dispêndios tributários.

Abordando diretamente a questão do controle dos gastos provenientes da concessão ou da ampliação do benefício físcal/incentivo fiscal, passou a exigir a realização de estimativa do impacto destes no orçamento ${ }^{303}$. Ou seja, com a entrada em vigor do

\footnotetext{
${ }^{302}$ Importante ressaltar o caráter acessório do demonstrativo ora sob exame. Trata-se, pois, de documento que consistiu peça de cunho informativo, que não integra a lei orçamentária.

${ }^{303}$ Art. 14. A concessão ou ampliação de incentivo ou benefício de natureza tributária da qual decorra renúncia de receita deverá estar acompanhada de estimativa do impacto orçamentário-financeiro no exercício em que deva iniciar sua vigência e nos dois seguintes, atender ao disposto na lei de diretrizes orçamentárias e a pelo menos uma das seguintes condições:

I - demonstração pelo proponente de que a renúncia foi considerada na estimativa de receita da lei orçamentária, na forma do art. 12, e de que não afetará as metas de resultados fiscais previstas no anexo próprio da lei de diretrizes orçamentárias;

II - estar acompanhada de medidas de compensação, no período mencionado no caput, por meio do aumento de receita, proveniente da elevação de alíquotas, ampliação da base de cálculo, majoração ou criação de tributo ou contribuição.

$\S 1 .^{\circ}$ A renúncia compreende anistia, remissão, subsídio, crédito presumido, concessão de isenção em caráter não geral, alteração de alíquota ou modificação de base de cálculo que implique redução discriminada de tributos ou contribuições, e outros benefícios que correspondam a tratamento diferenciado.
} 
mencionado diploma legal, a renúncia de receitas não mais poderia ser efetivada sem que se avaliasse seu efeito em relação às metas fiscais estipuladas pela Lei de Diretrizes Orçamentárias.

Passa, então, a ser indispensável que se demonstre que o montante renunciado está considerado na estimativa da receita da Lei Orçamentária e que não comprometerá as metas de resultados fiscais da Lei de Diretrizes Orçamentárias.

Caso tal demonstração não seja possível, necessário se faz o atendimento a comando legal que impõe a adoção de medidas compensatórias, aptas a aumentar a arrecadação tributária (elevação de alíquota, criação de tributo ou contribuição). Por força de tal preceito, não é possível que se veicule qualquer renúncia de receita enquanto as medidas compensatórias correlatas estiverem pendentes de concretização.

Insta pontuar que a estimativa de receita em foco, bem como as medidas compensatórias devem abarcar o ano de início da vigência da norma criadora do incentivo fiscal e os dois anos subsequentes. Nota-se aí uma preocupação do legislador complementar com a identificação da fonte de recursos supridora das quantias renunciadas, como meio de manutenção de um equilíbrio orçamentário.

Ao analisar as exigências em questão, Kiyoshi Harada ${ }^{304}$ conclui que estas tornam “impossível a supressão pura e simples de receitas, para atender aos diversos interesses públicos. É preciso demonstração prévia de que a renúncia não acarretará insuficiência de recursos financeiros para o atendimento das necessidades públicas, nem desequilíbrio fiscal a demandar transferências de recursos de outras esferas políticas".

Vale ressaltar que as restrições de que trata o art. 14 da Lei de Responsabilidade Fiscal não se aplicam em caso de alteração de alíquota efetuada no âmbito dos seguintes impostos: a) importação de produtos estrangeiros-II; b) exportação, para o exterior, de produtos nacionais ou nacionalizados - IE; c) produtos industrializados - IPI; e d) operações de crédito, câmbio e seguro, ou relativas a títulos ou valores mobiliários - IOF.

$\S 2 .^{\circ}$ Se o ato de concessão ou ampliação do incentivo ou benefício de que trata o caput deste artigo decorrer da condição contida no inciso II, o benefício só entrará em vigor quando implementadas as medidas referidas no mencionado inciso.

$\S 3 .^{\circ} \mathrm{O}$ disposto neste artigo não se aplica:

I - às alterações das alíquotas dos impostos previstos nos incisos I, II, IV e V do art. 153 da Constituição, na forma do seu $\S 10$;

II - ao cancelamento de débito cujo montante seja inferior ao dos respectivos custos de cobrança.

${ }^{304}$ HARADA, Kiyoshi. Op. cit., p. 62. 
Isto porque os referidos impostos federais possuem caráter eminentemente regulatório, não se submetendo nem mesmo ao princípio da legalidade quanto à modificação de alíquotas.

Também situadas fora da incidência do artigo 14 em comento estão as hipóteses de cancelamento de crédito tributário, cujas despesas para cobrança sejam a ele superiores.

Por outro lado, demonstrado que o benefício não gera dispêndio tributário, dúvidas surgem quanto à incidência do dispositivo em voga, que, em tese, seria voltado à hipótese em que se configura efetiva renúncia de receita.

Interessante questão que contribui para a análise em apreço é a do benefício a “custo zero", cuja concessão não implicará renúncia de receita, porquanto esta nunca existiu. Tal situação é verificada na hipótese de um contribuinte novo. Assim, no caso de empresa que se instala em determinada região do país para construção de indústria, a isenção que é concedida pelo Estado ou Município de ICMS e ISS, por exemplo, não implicará a diminuição de receita, já que antes da implantação da mencionada indústria os correlatos tributos jamais incidiriam. Não há, pois, perda na arrecadação.

Elcio Fiori Henriques ressalta que, nestas circunstâncias, apesar de a maioria da doutrina defender não ser necessária a submissão ao regime jurídico posto pela Lei de Responsabilidade Fiscal, este deveria ser seguido, já que o conceito de benefício fiscal ali plasmado é amplo e se refere à forma da norma benéfica, não à sua consequência financeira $^{305}$.

O presente estudo reputa oportuno o posicionamento do autor em tela, que, divergindo da vala comum da inaplicabilidade do regime da Lei Complementar n. ${ }^{\text {o }}$ 101/2000 aos benefícios/incentivos a custo zero, defende a sua aplicabilidade. Neste sentido, considerando o fato de que o regime em tela foi implantado com o fim de promover a transparência fiscal, a posição ora adotada é a de que, independentemente do resultado numérico encontrado e da sua repercussão no orçamento, é necessária a elaboração de demonstrativo que revele o quanto seria apurado de imposto caso os fatos geradores em foco não fossem alcançados pela norma desonerativa.

\footnotetext{
${ }^{305}$ O multicitado autor, depois de citar Carlos Maurício Cabral Figueiredo, Cláudio Soares de Oliveira Ferreira, Fernando Raposo Gameiro Torres, Henrique Anselmo Silva Braga, Marco Antônio Rios da Nóbrega, Ives Gandra da Silva Martins, Marcos Vinhas Catão e Régis Fernandes de Oliveira, sustenta que: "Sendo os benefícios fiscais instituídos para novos contribuintes efetivos 'benefícios', uma vez que correspondem a tratamento diferenciado em relação a outros contribuintes, enquadram-se no conceito de benefício fiscal instituído pelo art. $14, \S 1 .^{\circ}$, da Lei de Responsabilidade Fiscal, porque, como visto, o conceito de benefício fiscal determinado pela referida norma se reporta somente à forma da norma benéfica, e não à sua consequência financeira” (HENRIQUES, Elcio Fiori. Op. cit., p. 230).
} 
Assim, mesmo os incentivos fiscais "a custo zero", concedidos a uma empresa nova que se estabelece em determinado território, devem ser quantificados.

Com efeito, além de a apuração da referida estimativa consubstanciar inescapável requisito formal estipulado pelo diploma legal em destaque, afigura-se indispensável o atendimento aos requisitos postos pela Lei de Diretrizes Orçamentária - LDO, bem como a demonstração de que não haverá impactos à estimativa de receitas. Tal demonstração excluiria, obviamente, a realização de compensação por meio de aumento da carga tributária.

Firmados os requisitos delineados pelo texto constitucional e legal relativos aos efeitos financeiros dos incentivos fiscais, tem-se por concluído o exame dos requisitos gerais acerca desse instituto. Dar-se-á início, portanto, ao estudo dos incentivos fiscais na seara ambiental. 


\section{INCENTIVOS FISCAIS AMBIENTAIS}

\subsection{Aspectos gerais}

\subsubsection{Panorama geral para aplicação dos incentivos fiscais ambientais}

O conteúdo do item 2.3., dedicado à análise tributação como forma de defesa do meio ambiente, deixou claro que a complexidade dos mercados e os diferentes cenários sugerem a utilização de um conjunto de instrumentos para se alcançar o objetivo de reduzir os impactos ambientais atualmente produzidos.

No Brasil, cujo contexto é de país em desenvolvimento, com potencial para alcançar os índices de desenvolvimento humano, tecnológico e econômico dos países mais avançados nessas searas, tem-se revelado mais condizentes com sua realidade os estímulos ao seu crescimento, em vez do agravamento das atividades desempenhadas.

Nesta perspectiva e tendo em vista os altos patamares que já alcançou a carga tributária no país, é evidente que a concessão de incentivos fiscais com viés ambiental poderia servir de estímulo aos alcançados pela imposição fiscal a modificarem suas condutas para fazer jus à correlata desoneração, podendo contribuir, ainda, para a redução do preço final dos produtos e serviços.

Cleucio Santos Nunes ${ }^{306}$, no seu livro intitulado Direito tributário e meio ambiente, alerta para o fato de que a proteção do meio ambiente realizada por meio da elevação da carga tributária pode, na prática, servir apenas para aumentar o custo de produção, tendo como consequência o aumento da segregação da disponibilidade de bens produzidos a um grupo reduzido de contribuintes mais abastado e a formação de monopólios.

E, nesta toada, defende que o meio mais adequado para o estímulo e a conscientização do contribuinte, dentro da realidade econômica e social brasileira, seria o oposto, ou seja, mediante a concessão de incentivos fiscais.

A teoria do ótimo de Pareto, empregada ao regime das isenções, deve levar em consideração certas variáveis, sobretudo em um país que já possui carga tributária socialmente elevada, comparando-se com o ritmo

${ }^{306}$ NUNES, Cleucio Santos. Direito tributário e meio ambiente. São Paulo: Dialética, 2005. p. 161-163. 
de crescimento da sua economia e devolução precária de serviços públicos, condições indispensáveis à convivência social adequada. Por isso, não é tributando os custos das externalidades negativas por meio do total das despesas com a limpeza ou readaptação do meio degradado, por exemplo, que se consegue a preservação ideal do ambiente natural em relação ao mercado. Diante da cultura brasileira de avidez no exercício da atividade tributária, certamente a tributação ativa passará o custo do tributo ao mercado sem muitos critérios, somente em razão do argumento ideológico de que é necessário preservar.

Diante disso o ponto de ajuste mais adequado ao sistema jurídico brasileiro leva em consideração princípios de índole ambiental, tais como o do poluidor-pagador e prevenção, porém pela via indireta, isto é, concedendo isenções ou incentivos, como, por exemplo, deduções de base de cálculo dos tributos em relação àquele que polui menos.

A adoção de incentivos, em vez da majoração de tributos, poderá trazer resultados mais eficientes, visto que estimula o empreendedor a adquirir novas técnicas de preservação. Ninguém gosta de pagar tributos! Se o Estado abre mão de seu crédito, exigindo em contrapartida certos compromissos de preservação, estar-se-á diante de uma dupla vantagem: i) colaboração com o Estado como corretor de externalidades negativas (pigout); ii) maior eficiência na conscientização da necessidade de preservação do meio ambiente (princípio da cooperação).

Consuelo Yioshida ${ }^{307}$, ao se voltar especificamente para a questão da efetividade ambiental dos instrumentos financeiros e tributários, ressalta que a experiência demonstra que a exigência de reparação integral com base na responsabilidade objetiva dos poluidores, a imposição de tributos e sanções administrativas não têm impedido a degradação ambiental, estando o êxito e a efetividade da proteção ambiental calcados na adoção de medidas que, a par do desestímulo à degradação, prestigiem medidas de estímulos à prevenção, com lastro em atrativos econômico-financeiros.

Na mesma linha, Heleno Taveira Tôrres ${ }^{308}$ ressalta a pertinência de serem criados incentivos fiscais ambientais:

A título de introduzir um producente "interesse ecológico" na legislação tributária, seria sobremodo importante tomar outras medidas, distintas da pretensão de criação de novos impostos, além daquelas hipóteses de cabimento de tributos acima já elencadas. Para os fins preventivos ou mesmo corretivos, vincular direitos a subvenções ou isenções, prescrevendo como condição a observância e o cumprimento da legislação ambiental, afastando-se daqueles que causem danos ambientais, já poderia ser um modo de operar a interação de

307 YOSHIDA, Consuelo Yatsuda Moromizato. Tributação e políticas públicas: o ICMS ecológico. In: TÔRRES, Heleno Taveira (Org.). Direito tributário ambiental. São Paulo Malheiros, 2005. p. 533.

308 TÔRRES, Heleno Taveira. Da relação entre competências constitucionais tributária e ambiental: os limites dos chamados tributos ambientais. In:- (Org.). Direito tributário ambiental. São Paulo: Malheiros, 2005. p. 110 . 
competências pretendida, em favor do reclamo constitucional de preservação ambiental. Desse modo, o dever de proteção e vigilância sobre o meio ambiente poderia servir como determinante negativo do exercício da competência, na função de motivo para justificar política fiscal de desoneração tributária de certas categorias.

A própria Lei n. ${ }^{\circ}$ 6.938/1981, no seu art. 9. ${ }^{\circ}$, define como instrumento da Política Nacional do Meio Ambiente: "V - os incentivos à produção e instalação de equipamentos e a criação ou absorção de tecnologia, voltados para a melhoria da qualidade ambiental". Esses incentivos, que podem ser de natureza tributária, podem também vir sem custos adicionais de despesas estatais, por simples vinculação, a título de condição para obter parcelamentos, reduções de base de cálculo, incentivos ou isenções de qualquer natureza. [...] Transferir essa experiência para domínios tributários pode ser algo muito positivo.

[...] o fundamental é vir bem assinalada a necessária conexão entre a medida ambiental "natural" e o instrumento tributário.

De sua parte, pontua José Marcos Domingues de Oliveira ${ }^{309}$ : “[...] idealmente, o diferencial de carga tributária simbolizará o reconhecimento estatal da relevância ou irrelevância ambiental das decisões pessoais, profissionais ou empresariais dos administrados enquanto contribuintes, e para estes representará o incentivo físcal correspectivo".

Nota-se que, na União Europeia, composta por países que, na sua maioria, já experimentaram notável crescimento econômico, as políticas no domínio do meio ambiente têm como lastro uma interpretação do princípio do poluidor-pagador bastante restritiva, segundo a qual a concessão de auxílios de Estado, dentre eles os fiscais, a princípio seria considerada proibida, porquanto significaria a redução dos custos a serem arcados pelas empresas na prevenção ou na redução da poluição, pelas quais seriam responsáveis $^{310}$.

Contudo, até mesmo nas citadas nações desenvolvidas, cujo crescimento ao longo dos anos correspondeu à exploração da quase totalidade dos seus ativos ambientais, tem-se ponderado que o princípio do poluidor-pagador, nos moldes acima delineados, não possui condições de ser inteiramente observado em curto prazo, sendo necessário um período de transição em que o princípio seria observado de modo gradativo ${ }^{311}$.

\footnotetext{
${ }^{309}$ OLIVEIRA, José Marcos Domingues de. Direito tributário e meio ambiente, cit., p. 59.

${ }^{310}$ SOARES, Cláudia Dias. Op. cit., p. 10.

${ }^{311}$ Id. Ibid., p. 11.
} 
Assim sendo, os auxílios de Estado (dentre eles, a concessão de isenção de tributo ou a sua redução) acabam por contribuir para a aceleração do processo de criação de normas concretizadoras do primado em foco ${ }^{312}$.

Sob tal prisma, o próprio Tratado da União Europeia cuidou de apontar elementos a serem considerados para a elaboração de políticas na seara ambiental. O mencionado dispositivo determina que a União Europeia levará em conta: i) dados científicos e técnicos disponíveis; ii) as condições do ambiente nas diversas regiões da comunidade; iii) as vantagens e encargos que podem resultar da atuação e da ausência de atuação; iv) o desenvolvimento econômico e social da comunidade no seu conjunto e o desenvolvimento equilibrado das suas regiões.

A partir dos critérios acima delineados, Cláudia Dias Soares ${ }^{313}$, aplicando o princípio do poluidor-pagador de forma mais ampliada, justifica assim a concessão de auxílios estatais ambientais:

A necessidade de assegurar o desenvolvimento harmonioso e equilibrado
da Comunidade no seu conjunto e de ter em conta, na elaboração da
política comunitária neste domínio, as condições do ambiente nas
diversas regiões poderá justificar uma aplicação mais flexível do referido
princípio de forma a atender às disparidades regionais e a promover a
aproximação entre os níveis de desenvolvimento económico-social e de
respeito ambiental entre as várias regiões. Os dados técnicos e científicos
disponíveis podem também justificar o afastamento do mencionado
princípio no caso de as empresas, por não existirem soluções alternativas,
terem de adoptar um tipo de tecnologia ou um método de produção que
acarreta um aumento significativo dos seus custos para respeitar as
normas em vigor, nos casos em que o benefício social ultrapassa em larga
medida o benefício individual de cada empresa. A dimensão dos custos a
suportar pelo poluidor pode ser ainda uma outra justificação para se
afastar o princípio em causa. Nos casos em que o investimento em
melhorias ambientais é de tal forma elevado que se torna impossível ao
mercado internalizar esses custos, não parece realista pretender que se
faça uma aplicação estrita daquele princípio.

Observa-se, então, que dentro da própria União Europeia a concessão de estímulos fiscais pode ser justificada, em função: i) do déficit de desenvolvimento em determinadas regiões, ii) dos diferentes níveis de exploração ambiental; e iii) do descompasso econômico entre o valor investido em tecnologia para proteção ambiental e a capacidade de absorção deste pelo mercado.

\footnotetext{
${ }^{312}$ SOARES, Cláudia Dias. Op. cit., p. 10-12.

${ }^{313}$ Id. Ibid., p. 10.
} 
Trazendo tais considerações para a realidade brasileira, constata-se que a comparação do atual estágio de desenvolvimento econômico, tecnológico e de conservação dos seus ativos ambientais com o dos países desenvolvidos revela que a concessão de estímulos fiscais ambientais está ajustada ao contexto nacional. Isto porque viabiliza a aplicação, no país, de novos e dispendiosos recursos tecnológicos voltados a reduzir a exploração desmedida dos ativos ambientais. E, por serem incentivados, tais investimentos não representarão ônus excessivo, evitando, assim, a perda de competitividade de bens e serviços nacionais.

Logo, o contexto dos países em desenvolvimento enseja a concessão de estímulos à adoção de medidas que possibilitam um crescimento econômico efetivo e sustentável.

Ressalte-se que em 1974, a $\mathrm{OCDE}^{314}$, ao conceber a possibilidade de exceção à aplicação do princípio do poluidor-pagador, delineou três requisitos, a seguir indicados: i) restrição e seletividade àqueles setores da economia em que a sua não admissão geraria sérias dificuldades; ii) concessão por prazo certo, adaptado à implementação do programa ambiental do país em causa; e iii) inexistência de distorções significativas no comércio e investimentos internacionais ${ }^{315}$.

De acordo com a OCDE, as medidas que visam a beneficiar a defesa do equilíbrio do meio ambiente e a promover o desenvolvimento sustentável, excepcionando a clássica concepção do princípio do poluidor-pagador, deverão ser específicas para as áreas da economia que efetivamente precisam de apoio. Além disso, devem ser transitórias, perdurando durante o período suficiente à efetivação do programa escolhido, não sendo possível que sua veiculação origine problemas desproporcionais para a concorrência e para o crescimento econômico.

A Comissão Europeia ${ }^{316}$ elaborou o seu entendimento com base na aludida recomendação, defendendo que, diante da insuficiência do mercado para garantir, em determinadas situações, a busca por objetivos sociais e econômicos sem incorrer em custos sociais intoleráveis ou em demoras incompatíveis, é possível a intervenção dos poderes públicos para equalizar as insuficiências na oferta e na procura.

\footnotetext{
314 A OCDE, em 10 de março de 1974, estipulou que só seriam admissíveis as ajudas de Estado a investimentos ambientais nos casos em que se busca superar as exigências impostas pela legislação em vigor.

${ }^{315}$ SOARES, Cláudia Dias. Op. cit., p. 21.

${ }^{316}$ A Comissão Europeia é responsável por propor normas e controlar o desenvolvimento das diretivas.
} 
O professor da Universidade de Valência, Cristóbal Borrero Moro, em artigo intitulado "Límites del Derecho comunitario a los tributos ambientales"317, chama a atenção para o fato de que as isenções, para serem compatíveis com o ordenamento comunitário, devem estender-se aos produtos oriundos de outros Estados-membros com o objetivo de evitar tratamento diferenciado entre os itens nacionais e importados.

O mencionado jurista defende ser a isenção uma das técnicas tributárias que se pode manejar com o objetivo de preservação do meio ambiente, ressalvando, contudo, a necessidade de concretização do princípio da isonomia e da não discriminação.

\subsubsection{Princípios ambientais norteadores do instituto}

Terence Dorneles Trennepohl ${ }^{318}$ considera o princípio do poluidor-pagador um dos vetores que devem reger as políticas ambientais, buscando, entretanto, a aproximação dos princípios da precaução e da prevenção ao instituto dos incentivos fiscais ambientais.

Em obra originada de dissertação de mestrado, que aborda os incentivos fiscais no direito ambiental, o aludido autor reconhece ser possível a aplicação do princípio do poluidor-pagador, em caráter preventivo. Todavia, entende que, para fins de exame de planejamento de condutas e políticas públicas, seria "mais importante e significativo abordar o tema sob outro prisma, diverso daquele já idealizado pela maioria, pelo prisma do poluidor-pagador, e estudar mais detidamente a prevenção e a precaução, que sempre, e necessariamente, importam antecedência ao fato ambiental danoso"319.

O referido autor ressalta que, em se tratando de incentivos fiscais em matéria de meio ambiente, o manejo dos princípios da precaução e da prevenção seria mais coerente, uma vez que o princípio do poluidor-pagador se acha bastante associado ao momento posterior ao dano, em que é atribuída a responsabilidade àquele que polui e que deve pagar.

Com efeito, o fundamento para se conferir maior enfoque aos princípios da precaução e prevenção repousaria no fato de a sociedade, na atualidade, estar imersa numa

\footnotetext{
${ }^{317}$ MORO BORRERO, Cristóbal J. Op. cit., p. 10.

318 TRENNEPOHL, Terence Dorneles. Incentivos fiscais no direito ambiental: para uma matriz energética limpa e o caso do etanol brasileiro. 2. ed. São Paulo: Saraiva, 2011. p. 66.

${ }^{319}$ Id., loc. cit.
} 
rede de desenvolvimento de tal grau, que os instrumentos de controle e fiscalização ambiental já não seriam suficientes para promover uma proteção satisfatória ${ }^{320}$.

Pontua o mencionado autor que a sociedade hoje "se caracteriza pela fase de riscos sociais, políticos, ecológicos e individuais, criados pelo desenvolvimento, que não se coadunam mais com as formas de controle e proteção da sociedade industrial”. Portanto, a elevada produção de riscos impediria uma previsão acerca das consequências de potenciais acidentes nucleares, químicos, ambientais e genéticos ${ }^{321}$.

De sua parte, Cristóbal Borrero Moro aduz que o consagrado princípio do poluidorpagador, que irá determinar a imputação dos custos sociais aos contaminadores, não deve ser o único a balizar a concessão de tratamento tributário diferenciado, propondo a utilização, também, de outros critérios, tais como os princípios relacionados à prevenção e precaução dos danos ambientais ${ }^{322}$.

Acrescente-se às referidas considerações acerca do princípio do poluidor-pagador e dos princípios da prevenção e da precaução, como primados norteadores da concessão de incentivos fiscais, a análise feita por José Marques Domingues a respeito do princípio do poluidor-pagador $^{323}$.

Com efeito, o citado professor da Universidade Estadual do Rio de Janeiro examina o princípio do poluidor-pagador sob duas vertentes. Na primeira vertente, a impositiva, aduz que o princípio irá estabelecer o dever estatal de exigir do poluidor tributos em virtude da sua atividade objetivamente poluidora.

\footnotetext{
${ }^{320}$ TRENNEPOHL, Terence Dorneles. Op. cit., p. 67.

${ }^{321}$ Id., loc. cit.

322 Segundo o referido jurista, "Las ayudas de Estado también deben ser analizadas desde la perspectiva del principio quien contamina paga, ya que las exenciones se materializan en normas que se encaminan a proteger el medio haciendo recaer sobre la colectividad el coste de la política ambiental. Mientras que el principio de quien contamina paga determina la imputación de los costes sociales a los contaminadores. La política ambiental de La Comunidad se basará, entre otros, em el principio de quien contamina paga - art. 174.2 TCE. Ahora bien, esto no significa que los tributos ambientales nacionales deban basarse exclusivamente em dicho principio, ya que éste no es un principio exclusivo y excluyente em el âmbito comunitario. El establecimiento de otros principios, como el de cautela y de acción preventiva o el principio de corrección de los atentados al medio ambiente, preferentemente em la fuente misma - art. 174.2 TCE -, hacen posible el establecimiento de tributos ambientales con base em criterios distintos al principio de quien contamina paga. Desde esta perspectiva, cabe plantearse el establecimiento de exenciones ambientales o la articulación de tributos encaminados a financiar actuaciones de protección Del medio, articulados con base em el principio de capacidad económica. En definitiva, el principio de quien contamina paga no excluye las ayudas de estado. Um buen ejemplo lo constituye el artículo 175.5 TCE, al admitir excepciones de carácter temporal ante el establecimiento de medidas ambientales con base em el principio de quien contamina paga" (MORO BORRERO, Cristóbal J. Op. cit., p. 11).

${ }^{323}$ OLIVEIRA, José Marcos Domingues de. Direito tributário e meio ambiente, cit., p. 56-57.
} 
Por seu turno, o sentido seletivo deste primado irá determinar que o Poder Público gradue a tributação de modo a estimular atividades, processos produtivos ou consumos "ecologicamente corretos" e a desestimular o emprego de tecnologias defasadas, a produção e o consumo de bens "ecologicamente incorretos".

Trazendo as aludidas dimensões à realidade jurídica brasileira, o mencionado autor $^{324}$ assim conclui acerca da aplicação do citado princípio no manejo de estímulos tributários:

É que, mesclando os sentidos impositivos (fiscal) e seletivo (extrafiscal) do princípio ambiental do poluidor-pagador, a lei tributária tem condições de proceder a um discrímen legítimo entre poluidores e não poluidores, de forma a premiar estes últimos, que, satisfazendo o espírito constitucional, orientado para a promoção do equilíbrio ecológico (art. 225 da Constituição), colaboram para a preservação ambiental.

O presente estudo reputa extremamente ponderada a análise do autor em foco, porquanto não concentra o conteúdo deste primado na ideia de danos ocorridos no passado, permitindo assim que se possa conceber que um incentivo fiscal, longe de consistir numa ofensa a tal princípio, encontra fundamento neste, consubstanciando verdadeiro veículo concretizador do art.225 da Lei Maior, por fomentar a defesa do meio ambiente.

Com raciocínio semelhante acerca da acepção ampla do princípio do poluidorpagador, encontra-se Simone Martins Sebastião ${ }^{325}$, cuja contribuição vai além, ao acrescentar o argumento de que a adoção de condutas adequadas do ponto de vista ecológico tem como consequência a redução das despesas públicas e o incremento da qualidade de vida da comunidade local, responsável por também afetar a qualidade de vida global.

Constata-se, nessa altura, que todas as atividades humanas, em maior ou menor grau, poluem e trazem riscos, de modo que, quando o contribuinte deixa parte do seu imóvel com a cobertura vegetal preservada, investe em eficiência no consumo energético, redução da emissão de gases poluentes, utilização de matérias-primas renováveis, reciclagem e correto descarte de bens, dentre outras ações que reduzem o impacto ambiental, resta evidente que está prestando uma contribuição para a qualidade de vida em

\footnotetext{
${ }^{324}$ OLIVEIRA, José Marcos Domingues de. Direito tributário e meio ambiente, cit., p. 59.

${ }^{325}$ SEBASTIÃO, Simone Martins. Op. cit., p. 258.
} 
geral, numa atuação conjunta com o Estado, que não é o único incumbido de preservar o meio ambiente, consoante determina o art. 225 da Carta Política.

Assim, considerando a redução das despesas geradas para o Poder Público e os custos que o particular incorre para efetivar as aludidas medidas, fica claro que um tratamento tributário abrandado configura um reconhecimento àqueles que adotam esse comportamento ambientalmente orientado, não havendo que se falar em ofensa ao princípio do poluidor-pagador, na medida em que o agente que se queda omisso à questão ambiental não é contemplado pelo estímulo ambiental veiculado.

Conforme já exposto ao longo deste trabalho, o Estado, muitas vezes, deve intervir para que determinado objetivo social, econômico ou político seja alcançado numa velocidade superior à que naturalmente teria. No estágio atual de crise ambiental, em que a maior parte da fauna e da flora do planeta já se encontra devastada e em que é lançado no ambiente um volume altíssimo de gases de efeito estufa e de resíduos sólidos e líquidos, não há dúvidas de que, no âmbito tributário, não é possível se descartar, aprioristicamente, nenhuma forma de atuação, seja a graduação de forma mais severa da carga tributária daqueles que poluem, de modo a incluir os custos ambientais na formação dos seus preços, seja a desoneração (total ou parcial) daqueles que atuam de forma ecologicamente responsável.

Examinando especificamente a concessão de estímulos fiscais, cumpre registrar que esta poderá ser analisada tanto como instrumento concretizador do princípio do poluidorpagador, na sua vertente da seletividade, quanto como instrumento concretizador dos princípios da precaução e da prevenção, por buscar evitar consequências incertas decorrentes das catástrofes naturais e demais problemas ambientais oriundos da ação humana.

De fato, o incentivo fiscal ambiental irá contemplar aqueles que adotam comportamentos acordes com a defesa do meio ambiente, correspondendo a um tratamento tributário mais brando para contribuintes que se movem lastreados em critérios ambientais, o que irá, em ultima análise, reduzir as despesas do Estado nessa seara, além de proporcionar melhoria da qualidade de vida no planeta.

Neste contexto, a concessão de incentivo fiscal poderá ter como fundamento a prevenção de tragédias futuras de proporções inestimáveis, inerente a uma sociedade de risco, com alto grau de desenvolvimento; mas também pode estar atrelada a um estímulo 
para aqueles que pretendem transformar suas atividades, por mais singelas que sejam, de "poluentes" para "menos poluentes".

Em qualquer das hipóteses, estar-se-á premiando as condutas que se movem com o viés ambiental, com o escopo de fomentar a sua prática, de modo a se alcançar a proteção concreta do meio ambiente.

Logo, seja modificando-se a forma ambientalmente irresponsável de produção, consumo e descarte de resíduos inerentes ao estágio de desenvolvimento a que se chegou, seja adotando-se medidas que visem à redução de impactos ambientais que venham a evitar danos ambientais futuros, abre-se espaço para a concessão de tratamento tributário abrandado.

Noutras palavras, a autorização para a adoção de regime tributário diferenciado independe do momento a que se reporta a conduta ambientalmente orientada, se para danos passados ou futuros. Assim, deve ser aplicado o regime ordinário, ou, eventualmente, mais severo para aqueles que continuam a se pautar nos moldes tradicionais, insistindo em poluir, ainda que haja opção menos agressora ao meio ambiente.

Não bastasse a construção que extrai dos princípios do poluidor-pagador e da prevenção e da precaução fundamentação para veicular os incentivos fiscais de viés ambiental, o princípio do protetor-recebedor, que vem sendo desenvolvido pela doutrina e aplicado pela legislação de diversos países, inclusive no Brasil, contempla a referida autorização de forma ainda mais nítida e ampliada, pois abarca a proteção de forma geral, independentemente do momento a que esta se reporta.

Deveras, o primado em foco traduz de modo mais direto a noção de que se devem compensar aqueles que adotam comportamento proativo no que tange à transformação do padrão de produção e consumo, bem como à utilização de recursos ambientais, de sorte a promover a redução dos níveis de emissão de gases produtores de efeito estufa na atmosfera e de degradação do meio ambiente.

Assim, além dos pagamentos efetuados por serviços ambientais propriamente ditos, tal cânone irá respaldar tratamentos econômicos e financeiros diferenciados para aquelas atividades que impactam positivamente o meio ambiente, incluindo-se os tratamentos vantajosos de natureza tributária. 
Neste compasso, os princípios do poluidor-pagador (na sua acepção ampla), da prevenção e da precaução e do protetor-recebedor ganham concretude quando o Poder Público abstém-se (total ou parcialmente) de arrecadar tributo de agentes que adotam comportamentos ambientalmente orientados.

\subsubsection{Críticas dirigidas aos incentivos fiscais ambientais}

Muitas ressalvas são costumeiramente feitas em relação aos incentivos físcais em geral. Os maiores opositores reputam-nos como privilégios odiosos por inexistir critérios em relação aos fatos que irão ser estimulados e por haver a necessidade de realocação de receitas públicas para fazer face à renúncia de receita deles decorrentes.

Entretanto, consoante pontuado no item 3.1, tais críticas quedam fragilizadas quando se verifica que o instituto nada mais faz do que executar ações de incumbência do Estado, o que evita maiores despesas públicas no espectro de atuação do instituto. Além disso, o atendimento às regras e aos princípios constitucionais impostos pela Constituição Federal de 1988 impede que o instituto seja equiparado a benesses concedidas de forma aleatória e de maneira sorrateira e pouco transparente.

Insta pontuar que, no âmbito exclusivo dos incentivos fiscais ambientais, há críticas mais específicas. Dentre elas, as principais:

Defende-se que a criação do instituto é cara. De fato, são necessários estudos multidisciplinares, que demandam recursos humanos e financeiros, além de ser necessário que haja controle da correta aplicação do incentivo. Contudo, há de se ponderar que os seus resultados positivos podem evitar gastos muito maiores. Assim, por exemplo, o custo para formular um incentivo fiscal que estimule o correto descarte de resíduos, a exemplo do óleo de cozinha, pode inibir o entupimento das redes de água, um dos principais fatores para ocorrência de enchentes, e, por consequência, evitar vultosos dispêndios com reparação dos danos delas decorrentes.

Tanto é assim que as empresas de seguros, cientes da oportunidade de se estimular essa conduta como forma de prevenir custos maiores com indenizações aos prejuízos 
provenientes de enchentes, vêm investindo em programas de reciclagem de tal produto ${ }^{326}$. Portanto, há de ser contabilizada a economia gerada ao se estimular comportamentos que tornam o meio ambiente mais equilibrado, antes de considerá-lo dispendioso.

Assevera-se, ainda, que a diminuição de preço dos bens e dos serviços, decorrente do incentivo fiscal ecológico, irá culminar no aumento do consumo e da poluição, produzindo efeito contrário ao esperado. Primeiramente, diminuir o preço de bem mais sustentável irá estimular a opção por este em detrimento do menos sustentável, o que pressupõe que a substituição implicará, a princípio, ganho ambiental. Daí a se concluir que a aquisição de bem sustentável irá fomentar um consumo maior é especulação. Ora, se a energia eólica é incentivada e a decisão das pessoas é por adquiri-la em vez da energia advinda de termelétrica, isso não significa que o seu preço ficará irrisório, nem que o consumo de energia será aumentado. O estímulo irá viabilizar o acesso a bens mais limpos, e a questão do uso racional destes ou de qualquer outro bem, ainda que não sustentável, deve estar sempre presente em campanhas informativas.

Outra crítica que é direcionada ao instituto refere-se ao fato de que nem sempre os incentivos são direcionados às atividades e aos bens que estão efetivamente atrelados a um ganho ambiental. Tal crítica deve servir como um alerta, afinal, a seleção do substrato incentivado tem de ser criteriosa, sob pena de invalidação do incentivo por violação do princípio da igualdade (art. 150, I da CF/1988). Conforme se verá no tópico 4.4.3., dedicado à igualdade na concessão de incentivos fiscais ambientais, a identificação da vantagem ambiental é a primeira demonstração a ser feita para que o tratamento tributário discriminatório venha a ser considerado isonômico. Nesse sentido, a crítica em questão não atinge o instituto do incentivo fiscal ambiental, mas o seu manejo equivocado.

Ademais, há ressalvas ao instituto, no sentido de que este acaba por estimular condutas sustentáveis que já seriam realizadas mesmo sem a existência do incentivo fiscal ambiental, ou seja, seriam verificados windfalls benefits (benefícios não esperados). A esse respeito, também será demonstrado, que a indução de comportamentos é aspecto indispensável à aprovação no teste da "adequação" no caso de incentivo físcal ecológico, pelo que a inobservância desse requisito irá impossibilitar a sua criação válida no

\footnotetext{
${ }^{326}$ PORTO Seguro oferece mais pontos de coleta para reciclagem de óleo de cozinha, cartões, pilhas e baterias. Disponível em: <http://www.gebramseguros.com.br/blog/2012/09/03/porto-seguro-oferece-maispontos-de-coleta-para-reciclagem-de-oleo-de-cozinha-cartoes-pilhas-e-baterias> Acesso em: 5 de set. 2012.
} 
ordenamento jurídico pátrio, por também estar em desconformidade com o princípio da igualdade (item 4.4.3.).

Aduz-se que alíquotas padrão com poucas reduções evitam a ineficiência e a distorção da economia. Tal assertiva perde a sua força quando se tem em conta que os incentivos físcais ambientais estão a concretizar objetivo de relevo estipulado pela Lei Maior. Portanto, as reduções de alíquotas poderão ser admitidas, desde que ocorram em patamares que preservem, dentre outros, o princípio da livre concorrência, consoante também será abordado mais adiante (item 4.4.5.).

Os incentivos ambientais também são criticados, porquanto se defende que o atingimento da meta por ele estipulada desestimula a continuidade dos esforços para a redução dos impactos ambientais. Contudo, tal ataque pode ser rebatido, considerando que o período a ser concedido deve ser ajustado ao tempo necessário ao atingimento do aludido fim, além do que é possível e recomendável a estipulação de etapas prevendo novos objetivos a serem alcançados ao longo do tempo. Também esse aspecto será visto com mais vagar ao se analisar a igualdade na concessão de incentivos fiscais ambientais.

A difícil delimitação do incentivo, considerando que a lei, ao estabelecer de forma bem definida os seus critérios, não logra especificar todos os seus detalhes, também é costumeiramente assinalada. Entrementes, o uso de conceitos indeterminados por diplomas legais, acompanhado de um maior detalhamento do estímulo em ato normativo (instrução normativa, portaria), pode mitigar tal restrição ao instituto, sendo possível abarcar inúmeras particularidades verificadas na aplicação concreta do incentivo, consoante se verificará quando do exame da legalidade aplicada ao instituto em comento (item 4.4.2.).

Pinceladas as principais críticas destinadas ao instituto sob exame, cabe avançar na investigação dos fundamentos e dos temperamentos que o contexto da Carta Política de 1988 lhe impõe.

\subsection{Formulação implícita na Constituição}

Por consubstanciar inequívoco vetor constitucional com impactos para a sociedade e para a economia, a preservação ambiental deve estar refletida na tributação, haja vista que o tributo, no Estado Social e Democrático de Direito, não tem meios de ser 
eminentemente neutro, cabendo o manejo de instrumentos tributários, dentre eles, incentivos fiscais, para a consecução dos desígnios constitucionais, notadamente aqueles voltados ao desenvolvimento econômico e social.

É certo que só há previsão expressa na Lei Maior para criação de incentivos fiscais com o objetivo de "promover o equilíbrio do desenvolvimento socioeconômico entre as diferentes regiões do país" (art. 151, CF) e de estimular a proteção da família, mediante incentivos fiscais ao acolhimento, sob forma de guarda, de criança ou adolescente órfão ou abandonado (art. 227, § 3. ${ }^{\circ}, \mathrm{VI}$ ). Contudo, não é necessário comando específico para que se lance mão dos mencionados estímulos tributários.

Deveras, apesar de o legislador constituinte ou reformador não ter estipulado a criação de incentivos físcais ambientais, não se pode desconsiderar a parte final do comando extraído do art. 170, VI, da Carta Política, cuja norma, veiculada pela Emenda Constitucional n. ${ }^{\circ} 42$, de 2003, estabelece a promoção de um tratamento diferenciado de produtos e serviços, bem como dos seus processos de produção, de acordo com o critério de proteção ambiental.

Assim, as atividades sustentáveis devem ser estimuladas economicamente pelos mais diversos meios (financiamentos com taxas bonificadas, investimentos públicos, incentivos fiscais etc.), visto que a aplicação de tais instrumentos concretiza o referido comando constitucional.

Não bastasse a referida diretriz econômica, nos termos do art. 225 da Constituição Federal, as presentes e futuras gerações têm direito a um meio ambiente ecologicamente equilibrado, sendo atribuída a responsabilidade pela sua defesa e preservação à coletividade e ao Poder Público

Neste compasso, a Carta Magna atribui ao Estado e à sociedade a obrigação de cuidar da prevenção, controle, preservação, estímulo e reparo de danos causados no meio ambiente, a fim de que este se mantenha para gerações futuras.

Portanto, considerando que: i) há princípio específico da ordem econômica que aponta para tratamento diferenciado com base na redução do impacto ambiental; ii) o Poder Público é um dos responsáveis pela preservação do meio ambiente; e iii) o meio ambiente equilibrado é um direito das gerações presentes e futuras, claro está que o Estado não deve arcar de forma única e exclusiva com todos os ônus decorrentes da defesa do meio ambiente, sendo condizente com os objetivos constitucionais, todavia, que tal ente 
abra mão de parcela das receitas tributárias com o intuito de estimular o desenvolvimento de atividades realizadas de forma sustentável por determinados particulares, o que resultará em efeitos positivos para a coletividade.

De fato, o incentivo de natureza tributária conferido àqueles que se movem de acordo com o viés ambiental une o dever de conceder tratamento benéfico à atividade econômica de reduzido impacto ambiental com o dever de atuação em conjunto dos particulares e do Poder Público, em nome da garantia de um meio ambiente equilibrado para as gerações presentes e futuras.

Sob a ótica do Estado, abrir mão de parcela das receitas tributárias decorrentes das atividades econômicas sustentáveis significa o reconhecimento concreto por tal ente de que é agente responsável pela defesa do meio ambiente. Uma vez sendo o tratamento econômico privilegiado para aqueles indivíduos que investem em redução do impacto ambiental uma diretriz expressa da Lei Maior (art. 170, VI, da CF/1988), tal forma de se desincumbir do dever de preservação ambiental revela-se constitucionalmente amparada.

Dessa maneira, para que se possa identificar o montante total despendido com a causa ambiental, deverão ser somados aos gastos diretos com a proteção do meio ambiente os referidos gastos tributários (indiretos) atrelados especificamente a tal fim.

Pelo prisma do indivíduo, verifica-se que, como os investimentos ambientais não significam necessariamente um correlato retorno econômico, podendo, ao contrário, trazer problema de competitividade ao produto ou serviço, porquanto é possível ter seu preço incrementado em proporção superior ao que os consumidores estão dispostos a pagar, afigura-se necessário que haja um compartilhamento de tais despesas, em que o particular e o Estado possam dispor de recursos em prol da proteção do meio ambiente.

Tal raciocínio estende-se aos consumidores, que devem incluir a questão ambiental no seu critério de escolha, para atender a essa responsabilidade constitucional que também lhe foi imposta pelo art. 225. Assim, os incentivos fiscais que permitem a mais célere expansão e propagação de bens e serviços de baixo impacto ambiental e a um custo razoável, estimularão os consumidores a enveredarem pela trilha da sustentabilidade, hipótese em que, de novo, se observará a participação conjunta da sociedade e do Estado com o intuito de defender o meio ambiente, como preconizado pelo art. 225 da Carta Magna. 
O fundamento para a instituição do incentivo fiscal ambiental não repousa tão somente nas normas constitucionais contidas nos citados artigos 225 e 170, VI. Pauta-se no conteúdo que se extrai da Lei Maior acerca do desenvolvimento nacional propriamente dito. Os dispositivos constitucionais que tratam tanto da defesa do meio ambiente quanto do desenvolvimento nacional devem ser analisados em conjunto, porquanto já não se pode imaginar o desenvolvimento atual como o tradicional, repetido há duzentos anos.

Sobreleve-se que a realidade atual de crise ambiental e econômica internacional reforça essa interpretação e aplicação das normas constitucionais, porquanto uma concepção tradicional que culminou em crises, demanda que se pense em novas formas de superação dos problemas.

Portanto, a Lei Maior respalda novas ideias para o incremento econômico, ajustadas ao interesse das futuras gerações e comprometidas com a melhoria dos índices de desenvolvimento humano atuais. Com efeito, harmoniza-se com o arcabouço jurídico nacional programas de governo vinculados ao crescimento econômico sustentável.

Neste sentido, a criação de um programa estruturante de incentivos fiscais, lastreado em firmes alicerces e balizas jurídicas, poderá contribuir para o desenvolvimento sustentável de que trata a Carta Política de 1988.

Exposto o contexto em que se põe a autorização constitucional para a instituição de incentivos fiscais ambientais no país, apresentar-se-á, de modo panorâmico, incentivos de tal natureza e projetos de lei em curso.

Conforme se verá, embora se tenha evidenciado que as normas constitucionais ensejam a criação de programa estruturante, os exemplos levantados revelam que os incentivos fiscais ambientais vêm sendo criados de forma esparsa pelos entes tributantes. Tal característica também é verificada no Direito comparado. 


\subsection{Incentivos fiscais ambientais no Direito brasileiro e no Direito comparado}

\subsubsection{Incentivos fiscais ambientais no Direito brasileiro}

As normas constitucionais que embasam a criação dos incentivos ecológicos conferem ao legislador pátrio vasto campo para moldar a tributação de sorte a estimular os comportamentos ambientalmente orientados ${ }^{327}$.

Com efeito, antes mesmo de a questão ambiental ganhar foros de centralidade no debate mundial, em 1966, o Direito pátrio já contemplava norma fiscal federal voltada à defesa do meio ambiente.

A Lei n. ${ }^{\circ}$ 5.106, instituída em setembro de 1966, estipulou que as pessoas físicas e jurídicas poderiam abater de suas declarações de rendimentos os valores destinados ao

\footnotetext{
${ }^{327}$ Terence DornelesTrennepohl exemplifica como os entes políticos, no país, podem ajustar a tributação de modo a introduzir estímulos relacionados à questão ambiental: "No Brasil, ganha força a tese da tributação ambiental, principalmente quando vista pela lente dos incentivos, pois quase todos os tributos podem ser utilizados com essa conotação de sanção positiva, dita premial.

Entretanto, a maioria desses instrumentos ambientais tributários depende de iniciativas legislativas municipais e estaduais, notadamente da mobilização de parlamentares e autoridades executivas, além da sociedade civil, de forma a tornar a discussão participativa e democrática, sob pena de esvaziar o conteúdo deste novo filão tributário [...].

Os impostos de importação e exportação - II e IE, principalmente em razão da possibilidade da variação das alíquotas, também servem como eficazes instrumentos de política ambiental, se observada a preferência por produtos ambientalmente recomendados nas transações comerciais. Com os Estados se dá o mesmo.

Também é viável o emprego do Imposto sobre Propriedade de Veículos Automotores - IPVA na atividade ambiental. Para citar um caso específico, no Estado do Rio de Janeiro, por via da Lei n. ${ }^{\circ}$ 948/1985, os valores do IPVA são diferentes para carros a gasolina e a álcool, bem como àqueles destinados à coleta de lixo e limpeza urbana. Mais recentemente, houve o desconto de $75 \%$ no imposto para os carros com equipamento de gás natural.

Além disso, o Imposto sobre Transmissão causa mortis e Doação de Quaisquer Bens ou Direitos - ITBI pode ter serventia relacionada àqueles imóveis considerados produtivos ou de interesse ambiental, incluindo os patrimônios tidos como históricos ou culturais, e ter suas alíquotas e/ou base de cálculos variáveis conforme sua importância.

Os Municípios podem se valer do uso ambiental do Imposto Predial Territorial Urbano - IPTU, dados sua progressividade no tempo e seu uso de acordo com a função social da propriedade. $\mathrm{O}$ mesmo pode ser realizado com as taxas e contribuições de melhoria, dependendo da atividade a ser tributada.

Os impostos, as taxas e as contribuições, como visto, podem servir de instrumento à disposição dos anseios ambientais, implicando, como proposto, não a punição ou aumento da carga tributária, mas o emprego de isenções, reduções de base de cálculo ou benefícios outros, desonerando o contribuinte, desde que adotada a conduta desejada, no caso, de preservação ou, simplesmente, de não poluição.

O Estado, portanto, enquanto indutor de condutas, com a aplicação das normas jurídicas tributárias, pode, e deve, intervir no sentido de se fazer cumprir os preceitos de defesa do meio ambiente insculpidos na Constituição Federal" (TRENNEPOHL, Terence Dorneles. Incentivos tributários e meio ambiente: a sustentabilidade ambiental e o direito tributário. In: MARTINS, Ives Gandra; ELALI, André; Marcelo Magalhães (Coord.). Incentivos fiscais: questões pontuais nas esferas federal, estadual e municipal. São Paulo: MP Ed., 2007. p. 365).
} 
florestamento e reflorestamento. Nos termos do Decreto Lei n. ${ }^{\circ} 1.336 / 1974^{328}$, o percentual de dedução para as pessoas físicas seria de $20 \%$ sobre a quantia aplicada em projeto de reflorestamento devidamente aprovado pelo Instituto Brasileiro de Desenvolvimento Florestal. Por seu turno, as pessoas jurídicas chegariam a um percentual de cerca de $50 \%$ sobre o valor investido ${ }^{329}$.

A respeito desse incentivo, importa destacar as três condições para a sua fruição, quais sejam: (i) realizar o florestamento ou reflorestamento em terras de que tenham justa posse, a título de proprietário, usufrutuários ou detentores do domínio útil, ou de que, de outra forma, tenham o uso como locatários ou comodatários; (ii) aprovação prévia do projeto pelo Ministério da Agricultura, compreendendo um programa de plantio anual mínimo de 10.000 árvores; (iii) o florestamento ou reflorestamento projetados possam, a juízo do Ministério da Agricultura, servir de base à exploração econômica ou à conservação do solo e dos regimes das águas.

Ainda em âmbito federal, a Lei n. ${ }^{\circ}$ 9.393, de 19 de dezembro de 1996, isentou da cobrança do Imposto Territorial Rural - ITR os proprietários de áreas de reserva legal, de preservação permanente, de Reservas Particulares do Patrimônio Natural e de áreas de servidão florestal.

É necessário que sejam observados determinados requisitos, a saber: que a área seja de preservação permanente, de reserva legal, de interesse ecológico para a proteção dos ecossistemas, comprovadamente imprestável para qualquer exploração (agrícola, pecuária etc.). Que seja declarada de interesse ecológico e esteja sob regime de servidão federal, florestal e/ou ambiental, coberta por florestas nativas, primárias ou secundárias, em estágio

\footnotetext{
${ }^{328}$ O mencionado decreto-lei, dentre outras previsões, dispôs sobre incentivos fiscais a investimentos realizados por pessoas físicas e aplicou novo tratamento fiscal aos rendimentos de investimentos. Assim, nos termos do seu art. $2 .^{\circ}$ :

“Art. 2. ${ }^{\circ}$ As pessoas físicas poderão reduzir o imposto sobre a renda devido de acordo com a sua declaração em cada exercício, em montante equivalente aos valores que resultarem da aplicação dos percentuais abaixo especificados sobre as quantias que voluntária e efetivamente aplicarem, no ano-base, diretamente ou por intermédio de instituições financeiras, em quaisquer dos investimentos de interesse econômico ou social enumerados a seguir, observadas as limitações respectivas e a de que trata o $\S 1 .^{\circ}$ : $[\ldots]$

p) importâncias comprovadamente aplicadas, no transcurso do ano-base, em florestamento ou reflorestamento realizado de acordo com projeto aprovado pelo Instituto Brasileiro de Desenvolvimento Florestal: $20 \%$ (vinte por cento)".

${ }^{329}$ Com a publicação do Decreto-lei n. ${ }^{\circ} 1.503 / 1976$, que tratou de incentivos fiscais para empreendimentos florestais, parte deste incentivo foi revogado, culminando na impossibilidade de conceder-se benefícios fiscais para pessoas jurídicas.

Art. $1 .^{\circ}$ A partir de $1 .^{\circ}$ de janeiro de 1977 não mais serão concedidos, a pessoas jurídicas, incentivos fiscais para florestamento ou reflorestamento nas condições prevista na Lei n. ${ }^{\circ}$ 5.106, de 2 de setembro de 1966.
} 
médio ou avançado de regeneração, dentre outras específicas condições exigidas legalmente.

Por seu turno, o Decreto n. ${ }^{\text {7 } 755 / 1993}$ estabeleceu alíquotas diferenciadas, em relação ao IPI, de veículos movidos a gasolina e a álcool. Sobreleve-se que o alvo não era o controle da poluição, mas o estímulo à produção de álcool visando à redução da importação de petróleo. Foi constatada, no entanto, razoável diminuição nos níveis de poluição atmosférica nos grandes centros urbanos.

Recentemente, foi editada a Lei n. $^{\circ} 11.828 / 2008$, que dispõe sobre medidas tributárias aplicáveis às doações em espécie recebidas por instituições financeiras públicas controladas pela União e destinadas a ações de prevenção, monitoramento e combate ao desmatamento e de promoção da conservação e do uso sustentável das florestas brasileiras.

Referido dispositivo legal instituiu a suspensão da incidência da Contribuição para o PIS/PASEP e COFINS no caso de doações recebidas pelas instituições financeiras públicas, quando aplicadas nas ações de preservação ambiental descritas na lei.

As instituições financeiras públicas controladas pela União, como beneficiárias do incentivo, caso não destinem os recursos, observado o prazo de dois anos, contados do mês seguinte ao recebimento da doação, ficam obrigadas a recolher as contribuições não pagas, acrescidas de juros e multa de mora, na forma da lei.

Além desses incentivos fiscais federais veiculados por lei, cumpre mencionar a Medida Provisória n. ${ }^{\circ}$ 75, editada em 2002, segundo a qual seria concedido crédito presumido de IPI (Imposto Sobre Produtos Industrializados) a estabelecimentos industriais que adquirissem resíduos plásticos para utilização como matéria-prima ou produto intermediário.

Na exposição de motivos, restou evidente o objetivo de tal incentivo de estimular a reciclagem dos desperdícios, resíduos e aparas de plástico, minimizando, com isso, os graves danos que estes causam ao meio ambiente.

O direito à fruição do crédito presumido corresponderia ao valor resultante da aplicação da maior alíquota do imposto, dentre as estabelecidas para os produtos classificados nas posições 39.01 a 39.14, sobre o valor de aquisição daqueles desperdícios, resíduos ou aparas, ocorrendo o aproveitamento do crédito em conformidade com normas que deveriam ser expedidas pela Secretaria da Receita Federal. Sucede que a referida 
medida provisória foi rejeitada pela Câmara dos Deputados na sessão de 18 de dezembro de 2002.

Impende ressaltar, todavia, que por meio do Decreto n. ${ }^{0} 7.619 / 2011$ foi prevista a concessão, até 31.12.2014, de crédito presumido de IPI na aquisição de resíduos sólidos, assim entendidos como: materiais, substâncias, objetos ou bens descartados, resultantes de atividades humanas em sociedade.

Tal incentivo somente é aplicado em relação a resíduos adquiridos diretamente de cooperativas de catadores de materiais recicláveis, constituídas de, no mínimo, vinte cooperados pessoas físicas, sendo vedada, neste caso, a participação de pessoas jurídicas.

Cumpre salientar que, na esteira do citado diploma legal, encontra-se a Proposta de Emenda Constitucional - PEC de n. ${ }^{\circ} 01 / 2012$ SC $^{330}$, que vem sendo designada como PEC dos reciclados. De acordo com tal proposta, seria afastada toda tributação incidente sobre produtos elaborados preponderantemente com materiais reaproveitados ou reciclados.

Somados a esses incentivos e à citada $\mathrm{PEC}$, ainda existem diversos projetos de leis em trâmite no Congresso Nacional que versam sobre incentivos fiscais ambientais.

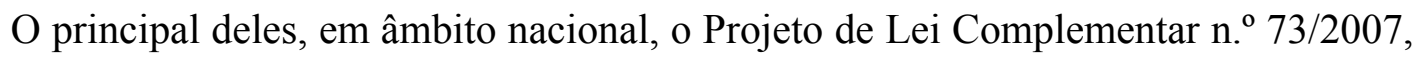
objetiva, com maior destaque, a caracterização da essencialidade de produtos com base nos impactos ambientais decorrentes dos respectivos ciclos produtivos, estabelecendo redução da carga tributária para os bens que, na sua produção, uso ou consumo, apresentem balanço de emissões de gases de efeito estufa mais favorável que seus concorrentes, ou que causem menor degradação ambiental, em razão de procedimentos produtivos empregados e dos insumos utilizados.

Além disso, onera as emissões de gases que intensifiquem o efeito estufa durante os processos produtivos de bens e serviços, instituindo uma Cide (Contribuição de Intervenção sobre o Domínio Econômico), cujos recursos arrecadados deverão ser aplicados, exclusivamente, para financiamento de projetos de inovação tecnológica em energia renovável e relativos a sequestro de gases de efeito estufa.

\footnotetext{
${ }^{330}$ Proposta de Emenda Constitucional - PEC de n. ${ }^{\circ}$ 01/2012 SC. BRASIL. Senado Federal. Proposta de Emenda à Constituição Federal PEC n. ${ }^{\circ}$ 1/2012. Altera o art. 150, VI, da Constituição Federal, para instituir imunidade de impostos incidentes sobre produtos elaborados preponderantemente com insumos provenientes de reciclagem ou reaproveitamento. Disponível em: <http://www.senado.gov.br/atividade/materia/detalhes.asp?p_cod_mate=104116>. Acesso em: 3 nov. 2012.
} 
No que tange aos projetos de leis ordinárias federais, há em tramitação o Projeto de Lei n. ${ }^{\circ} 5.974 / 2005^{331}$. O citado projeto de lei dispõe sobre a possibilidade de deduzir do Imposto de Renda os valores doados a entidades sem fins lucrativos pelas pessoas físicas e jurídicas, a serem aplicados em projetos destinados a promover o uso sustentável dos recursos naturais e a preservação do meio ambiente.

Os projetos ambientais referidos nesta Lei, acompanhados de planilhas de custos, serão submetidos ao Ministério responsável pela política nacional de meio ambiente e, para serem aprovados, deverão enquadrar-se nas diretrizes, prioridades e normas do Fundo Nacional do Meio Ambiente, estabelecido por meio da Lei n. ${ }^{\circ}$ 7.797, de 10 de junho de 1989.

Quanto ao benefício, as pessoas físicas e jurídicas poderão deduzir do Imposto de Renda por elas devido, respectivamente, até $80 \%$ e até $40 \%$ dos valores efetivamente doados, observado o limite global de 4\% do Imposto de Renda devido.

O projeto em foco encontra-se apensado aos projetos de Lei n. ${ }^{\circ} 7.224 / 2010^{332}$, n. $^{\circ}$ $1.428 / 2011^{333}$ e n. ${ }^{\circ} 3.873 / 2012^{334}$, porquanto todos versam sobre incentivos fiscais ambientais. Tais projetos, atualmente, estão sujeitos à apreciação do Plenário da Câmara dos Deputados.

Com efeito, o Projeto de Lei n. ${ }^{\circ} 7.224 / 2010$ tem como escopo conceder incentivo fiscal do Imposto sobre a Renda às pessoas físicas ou jurídicas que implantarem projetos de reflorestamento e florestamento e de preservação do meio ambiente. O aludido estímulo

331 BRASIL. Câmara dos Deputados. Projeto de Lei PL 5974/2005. Dispõe sobre incentivos fiscais para projetos ambientais. Disponível em: $<$ http://www.camara.gov.br/proposicoesWeb/fichadetramitacao?idProposicao=301799>. Acesso em: 3 jan. 2012.

${ }^{332}$ Projeto de Lei n. ${ }^{\circ}$ 7.224/2010. BRASIL. Câmara dos Deputados. Projeto de Lei PL n. ${ }^{\circ}$ 7.224/2010. Concede incentivo fiscal do Imposto sobre a Renda às pessoas físicas ou jurídicas que implantarem projetos de reflorestamento e florestamento e de preservação do meio ambiente. Disponível em: $<$ http://www.camara.gov.br/proposicoesWeb/fichadetramitacao?idProposicao=474940>. Acesso em: 9 set. 2012.

${ }^{333}$ Projeto de Lei n. ${ }^{\circ}$ 1.428/2011. BRASIL. Câmara dos Deputados. Projeto de Lei PL n. ${ }^{\circ} 1.428 / 2011$. Institui benefício fiscal a empresas que apresentem projetos de conservação e proteção de parques de alta relevância ambiental previamente aprovados pelo Ministério do Meio Ambiente. Disponível em: $<$ http://www.camara.gov.br/proposicoesWeb/fichadetramitacao?idProposicao=503589>. Acesso em: 9 set. 2012.

${ }^{334}$ Projeto de Lei n. ${ }^{\circ}$ 3.873/2012. BRASIL. Câmara dos Deputados. Projeto de Lei PL n. ${ }^{\text {o }}$ 3.873/2012. Institui incentivo fiscal para projetos ambientais e projetos culturais e artísticos de conteúdo ecológico integrantes da programação da Conferência Internacional Rio +20 . Disponível em: $<$ http://www.camara.gov.br/proposicoesWeb/fichadetramitacao?idProposicao=544765>. Acesso em: 9 set. 2012 . 
fiscal reativaria o incentivo concedido pela Lei n. ${ }^{\circ}$ 5.106/1966, revogado pelo Decreto Lei n. ${ }^{\circ} 1.503 / 1976$, ambos mencionados anteriormente.

Deveras, por meio de tal estímulo, as pessoas físicas em geral e as jurídicas, se tributadas com base no lucro real, estariam autorizadas a deduzir os valores aplicados nos projetos em até $10 \%$ do imposto devido, sem exclusão ou limitação de outros benefícios, deduções ou abatimentos em vigor.

Em contrapartida, o contribuinte que efetuar as deduções será responsável por quaisquer irregularidades resultantes dos projetos de que trata o referido diploma legal. Assim, a infração aos seus dispositivos sujeitará o contribuinte ao pagamento do valor do imposto devido em relação a cada período de apuração, com as respectivas penalidades e acréscimos legais, sem prejuízo das sanções penais cabíveis.

Além disso, a dedução somente será cabível se previamente reconhecida pela Delegacia da Receita Federal a que estiver jurisdicionado o contribuinte solicitante.

Ainda sobre os projetos, que tramitam conjuntamente, ressalte-se o Projeto de Lei n. ${ }^{\circ}$ 1.428/2011, segundo o qual as empresas tributadas pelo lucro real, que executam projetos de conservação e proteção de parques de alta relevância ambiental, previamente aprovados pelo Ministério do Meio Ambiente, estariam autorizadas a deduzir até 20\% das despesas realiza das no respectivo período de apuração, no limite de até $2 \%$ do Imposto de Renda devido.

Destaque-se que não poderão ser deduzidas as despesas que, de acordo com a legislação em vigor, a pessoa jurídica estaria obrigada a realizar para preservação, proteção, manutenção ou recuperação da área definida no projeto.

Por fim, o derradeiro projeto apensado, de n. ${ }^{\circ} 3.873 / 2012$, institui incentivo fiscal de Imposto de Renda (IR) e Contribuição Social sobre Lucro Líquido (CSLL) para as pessoas jurídicas que patrocinarem os projetos ambientais, culturais e artísticos, de conteúdo ecológico, integrantes da programação da conferência Rio +20 .

As pessoas jurídicas beneficiárias poderão deduzir até $20 \%$ do valor devido relativo ao IR e $8 \%$ da CSLL, até o limite de $\mathrm{R} \$ 500.000,00$ por pessoa jurídica e $\mathrm{R} \$ 250.000,00$ por projeto ou cota de patrocínio de projeto. 
Com relação, ainda, aos projetos de lei em andamento, agora quanto ao IPI (Imposto sobre Produtos Industrializados), há projeto de lei de incentivo ambiental concedendo isenção, pelo prazo de 10 anos, do IPI sobre veículos de passageiros e mistos movidos a tração elétrica, na tentativa de estimular a aquisição desse tipo de automóvel, em contraponto aos veículos à base de combustíveis danosos ao meio ambiente. Esse

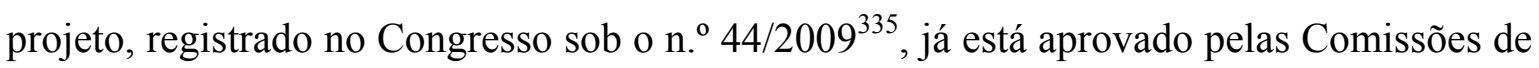
Assuntos Sociais e de Serviços e Infraestrutura.

Ademais, o Projeto de Lei n. ${ }^{\circ} 533 / 2011^{336}$ visa a instituir, mediante pagamento por serviços ambientais - PSA, incentivos na redução da base de cálculo para recolhimentos referentes ao IRPJ, IPI, PIS e COFINS para as empresas que exerçam atividade de controle ambiental, desde que inscritas no Ministério do Meio Ambiente.

Essas atividades envolvem coleta de resíduos, tratamento e despoluição do ar e da água, bem como a produção de máquinas e equipamentos e o desenvolvimento de tecnologias e projetos, além da prestação de serviços de controle ambiental para a eliminação de resíduos do ar e da água.

Os incentivos compreendem a redução das bases de cálculo para recolhimentos referentes ao IRPJ, IPI, PIS e COFINS, inclusive no que concerne à incidência sobre importação, em montantes a serem estabelecidos em regulamento.

Além disso, as empresas destinatárias finais das atividades relacionadas nessa lei, desde que se antecipem no cumprimento dos prazos impostos pelos órgãos de fiscalização sanitária e combate à poluição, poderão deduzir até $50 \%$ dos valores gastos com equipamentos de controle ambiental da base de cálculo de seu IRPJ e de sua CSLL, em escala progressiva, proporcional ao tempo de antecipação.

O projeto em tela encontra-se na Comissão de Constituição, Justiça e Cidadania, aguardando avaliação e parecer da Relatoria.

\footnotetext{
${ }^{335}$ Projeto de Lei n. ${ }^{\circ}$ 44/2009. BRASIL. Senado Federal. Projeto de Lei PLN n. ${ }^{\circ} 44 / 2009$. Concede isenção do Imposto sobre Produtos Industrializados aos veículos de passageiros e mistos movidos a tração elétrica. Disponível em: <http://www.senado.gov.br/atividade/materia/detalhes.asp?p_cod_mate=89535>. Acesso em: 9 set. 2012.

${ }^{336}$ Projeto de Lei n. ${ }^{\circ}$ 533/2011. BRASIL. Senado Federal. Projeto de Lei PLS n. ${ }^{\circ}$ 533/2011. Autoriza o Poder Executivo a instituir incentivos fiscais destinados a estimular as pessoas jurídicas que exerçam atividade de controle ambiental de resíduos. Disponível em: $<$ http://www.senado.gov.br/atividade/materia/detalhes.asp?p_cod_mate=101943>. Acesso em: 9 set. 2012.
} 


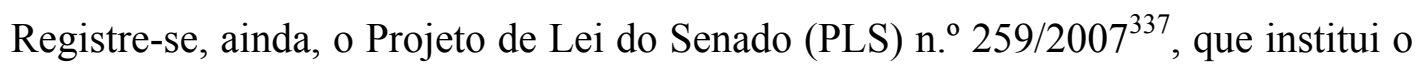
Programa de Substituição de Embalagens Plásticas Convencionais por Congêneres Biodegradáveis. Desse modo, as pessoas jurídicas de direito privado que investirem na fabricação de embalagens plásticas biodegradáveis farão jus a incentivos fiscais e creditícios, nos termos de legislação específica.

Na Comissão de Meio Ambiente, Defesa do Consumidor e Fiscalização e Controle, um dos argumentos expostos para a rejeição do projeto é que o ordenamento jurídico brasileiro já disciplina satisfatoriamente a questão desde a edição da Lei n. ${ }^{\circ} 12.305$, de 2 de agosto de 2010, que instituiu a Política Nacional de Resíduos Sólidos.

De forma exatamente inversa, os fundamentos para a aprovação estão pautados pelo disposto na Política Nacional de Resíduos Sólidos, de modo a dar mais densidade e concretude aos dispositivos da Lei n. ${ }^{\circ}$ 12.305/2010.

Não obstante essas opiniões, as minutas dos pareceres já proferidas ainda não foram apreciadas e o projeto ainda não foi levado à votação nessa Comissão.

Um dos mais interessantes projetos, pela singularidade da propositura, é o de $\mathrm{n}^{\mathrm{o}}$ $3.674 / 2012^{338}$.

Tal projeto visa incentivar a abertura da "primeira empresa" - PE criada por pessoa(s) física(s) que nunca teve (tiveram) seu nome vinculado a outras empresas e da "primeira empresa para economia verde" - PEEV -, em atenção aos fins socioambientais, mediante parecer de órgão técnico, permitindo que dentro de um determinado prazo todos os impostos, taxas, contribuições e encargos sejam convertidos, automaticamente, em créditos a elas, a serem pagos no futuro.

Tais empresas seriam consideradas instrumentos para o desenvolvimento nacional e para o alcance dos objetivos fundamentais da República, estabelecidos no art. $3 .^{\circ}$ da Constituição Federal.

\footnotetext{
${ }^{337}$ Projeto de Lei n. ${ }^{\circ}$ 259/2007. BRASIL. Senado Federal. Projeto de Lei PLS n. ${ }^{o}$ 259/2007. Dispõe sobre o Programa de Substituição de Embalagens Plásticas Convencionais por Congêneres Biodegradáveis. Disponível em: <http://www.senado.gov.br/atividade/materia/detalhes.asp?p_cod_mate $=81036>$. Acesso em: 5 ago. 2012.

338 Projeto de Lei n. ${ }^{\circ}$ 3.674/2012. BRASIL. Câmara dos Deputados. Projeto de Lei PL 3.674/2012. Cria incentivos para a abertura e funcionamento da "Primeira Empresa", da "Primeira Empresa para Economia Verde", e dá outras providências. Disponível em: $<$ http://www.camara.gov.br/proposicoesWeb/fichadetramitacao?idProposicao=541085>. Acesso em 09 out. 2012.
} 
Para tanto, nos primeiros 24 meses, todos os impostos, taxas, contribuições e encargos devidos a ente federal serão convertidos, automaticamente, em créditos à empresa, não se incluindo no incentivo o Fundo de Garantia por Tempo de serviço (FGTS) devido aos empregados dessas empresas.

Após esse prazo, a empresa dará início ao recolhimento à Receita Federal do Brasil do que fora transformado em crédito, tendo o prazo de 48 meses para sua quitação, a qual deverá ser realizada à razão de $50 \%$, a cada mês, dos valores mensais recebidos desde o primeiro até o último mês que tiver gozado do incentivo.

Para o enquadramento da empresa, além da confirmação de que o(s) sócio(s) nunca participou (participaram) de outra empresa, devem ainda apresentar à RFB uma autorização, da parte de cada um dos seus sócios, para a penhora de até $15 \%$ de quaisquer rendas futuras que vierem a auferir, para garantia do crédito em tela, na proporção de suas participações societárias na primeira empresa.

O projeto aguarda parecer na Comissão de Desenvolvimento Econômico, Indústria e Comércio.

Já no âmbito estadual, o estímulo fiscal de maior repercussão atualmente é o "ICMS ecológico". Apesar de não constituir um incentivo fiscal propriamente dito, sendo tão só fruto da utilização de critério ambiental para repasse financeiro de receitas públicas aos Municípios, cumpre mencionar, pela sua relevância, que o referido instrumento já foi adotado por diversos Estados da federação, a exemplo do Paraná, Ceará, Pernambuco, Rio Grande do Sul, Rio de Janeiro, Rondônia, Amapá, Acre, Mato Grosso, Minas Gerais e São Paulo.

O ICMS ecológico tem como fonte normativa o art. 158 da CF/1988, segundo o qual as receitas tributárias arrecadadas pela União e pelos Estados são pertencentes aos municípios. Dentre tais receitas está o percentual de $25 \%$ do que é arrecadado a título de ICMS, cujos critérios de repartição entre os municípios estão postos no parágrafo único do mencionado artigo.

Nos termos da Lei Maior, no mínimo 3/4 dos 25\% de ICMS pertencentes aos municípios devem ser repassados conforme o valor fiscal adicionado das operações realizadas por cada ente municipal, ou seja, os municípios de maior produção e desenvolvimento terminam por ser beneficiados. O remanescente pode ser repartido conforme critérios adotados pelos Estados. 
Considerando que os critérios influem sobre as políticas públicas como um fator de indução econômica, alguns Estados optaram por harmonizar a sistemática financeira com a preservação ambiental, incentivando os municípios que possuem áreas de preservação ambiental, com o intuito de evitar que estes não sofram perdas em decorrência do limitado desenvolvimento econômico. Nota-se que, se antes o escopo era uma função compensatória, hoje passou a ter uma função incrementadora ${ }^{339}$.

No que toca ao incentivo fiscal propriamente dito, calha mencionar a Política Estadual de Apoio a Produção e a utilização do Biodiesel, de Óleos Vegetais e de Gordura Animal, veiculada pelo Estado de Mato Grosso com a edição da Lei n. ${ }^{\circ}$ 8.794/2008.

Esta política tem por objetivo apoiar a produção e buscar o aumento da produtividade, integrando o Estado no esforço de introdução do biodiesel, óleos vegetais e gordura animal na matriz energética nacional, promovendo os benefícios sociais, ambientais e econômicos decorrentes da utilização de tais produtos.

Para tanto, além do financiamento de projetos de pesquisa e incentivos à produção e à comercialização desses produtos, fica instituído, por meio dessa lei, incentivo físcal com a redução da carga tributária final desses produtos.

Nas operações com Biodiesel - B100, a redução da carga tributária final fica entre 0 e 7\%; nas operações realizadas com matérias-primas oriundas da agricultura familiar, a carga tributária oscila entre 0 e $3 \%$, limitada a $30 \%$ da produção do estabelecimento industrial.

Além deste incentivo, diversos Estados do país isentam veículos movidos a motor elétrico da cobrança do IPVA (Imposto sobre Propriedade de Veículos Automotores), tais como Ceará, Maranhão, Pernambuco, Piauí, Rio Grande do Norte, Rio Grande do Sul e Sergipe $^{340}$.

Já os Estados do Mato Grosso do Sul, Rio de Janeiro e São Paulo estabelecem alíquotas diferenciadas na cobrança desse mesmo imposto para os proprietários dos veículos movidos a motor elétrico ou gás natural.

\footnotetext{
${ }^{339}$ SCAFF, Fernando Facury; TUPIASSU, Lise Vieira da Costa. Op. cit., p. 734-735.

${ }^{340}$ Ceará (Lei 12.023 - art. 4. ${ }^{\circ}$, IX); Maranhão (Lei 5.594 - art. 9. ${ }^{\circ}$, XI); Pernambuco (Lei 10.849 - art. 5. ${ }^{\circ}$, XI); Piauí (Lei 4.548 - art. 5. ${ }^{\circ}$, VIII); Rio Grande do Norte (Lei 6.967 - art. 8. ${ }^{\circ}$, XI); Rio Grande do Sul (Lei 8.115 - art. $4 .^{\circ}$, II) e Sergipe (Lei 3.287 - art. $4 .^{\circ}$, XI).
} 
No Mato Grosso do Sul, por exemplo, a Lei n. ${ }^{\circ} 1.810$, em seu art. 153, prevê a possibilidade de o Poder Executivo reduzir em até 70\% o IPVA de veículo acionado a eletricidade ou a gás.

Por seu turno, no Rio de Janeiro, o IPVA incide a uma alíquota de 1\% sobre veículos que utilizem energia elétrica ou gás natural, a teor do que estipula o inciso VII do artigo 10 da Lei.$^{\circ} 2.877$.

Já em São Paulo, a propriedade de automóveis de passeio, de esporte, de corrida e camionetas de uso misto, movidos a eletricidade ou gás natural, enseja a cobrança de IPVA a uma alíquota de $3 \%$, conforme o inciso III do art. $7 .^{\circ}$ da Lei n. ${ }^{\circ} 6.606$.

Existe, ainda, no Estado de Pernambuco, o Projeto de Lei Ordinária n. ${ }^{\circ}$ $872 / 2012^{341}$, que tem como objetivo estimular o uso de energias renováveis, mediante a criação do Programa de Sustentabilidade na Atividade Produtiva do Estado de Pernambuco - PESUSTENTÁVEL. Este programa prevê a concessão de crédito presumido sobre o saldo devedor mensal do ICMS.

A concessão do incentivo ocorre mediante aprovação de projeto de intenção de consumo de energia de fontes renováveis apresentado à Secretaria de Meio Ambiente e Sustentabilidade - SEMAS, que deverá emitir parecer técnico conjunto com a Secretaria de Recursos Hídricos e Energéticos - SRHE e com a Secretaria da Fazenda - SEFAZ.

Vale ressaltar que o prazo máximo para apresentação do parecer é de 60 dias, transcorridos a partir da protocolização do projeto.

Quanto às limitações do incentivo, o crédito presumido não poderá ser superior a 5 pontos percentuais e não poderá, se combinado a outros programas de incentivos fiscais, implicar recolhimento de ICMS normal inferior a $1 \%$ do saldo devedor original, antes da dedução de qualquer incentivo.

O incentivo será concedido por meio de decreto específico para a empresa beneficiária, pelo prazo máximo de 10 anos.

\footnotetext{
${ }^{341}$ Projeto de Lei Ordinária n. ${ }^{\circ} 872 / 2012$ - PE. ASSEMBLEIA LEGISLATIVA DO ESTADO DE PÉRNAMBUCO. Projeto de Lei 872/2012. Cria o Programa de Sustentabilidade na Atividade Produtiva do Estado de Pernambuco - PESUSTENTÁVEL. Disponível em: $<$ http://www.alepe.pe.gov.br/paginas/verprojeto.php?id=3598\&paginapai $=3576 \&$ numero=872\%2F2012 $>$. Acesso em: 9 out. 2012.
} 
Não apenas nos âmbitos federais e estaduais existem incentivos fiscais ecológicos. Também no âmbito municipal são concedidos diversos incentivos fiscais ambientais, em sua maioria, em sede do Imposto Predial e Territorial Urbano - IPTU.

Com efeito, no Município de Vila Velha - ES, nos termos da Lei Municipal n. ${ }^{\circ}$ 4.864, de 30 de dezembro de 2009, os proprietários de imóveis localizados na zona urbana podem ser beneficiados por um incentivo fiscal com a redução do pagamento do IPTU em até $50 \%$ de desconto.

Assim, caso os contribuintes do Município optem por cuidar adequadamente das calçadas construídas regularmente, ou as construam adotando o projeto padrão "calçado cidadã" do Município, o desconto alcançado é de 10\%. Possuindo ou plantando, respectivamente, uma, duas ou três árvores, terão redução desse imposto na proporção de $10 \%, 12 \%$ ou $18 \%$.

Esses dois incentivos serão fruídos apenas por proprietários de imóveis edificados com até dois pavimentos.

O máximo do incentivo, $50 \%$ de redução, é aplicável para os proprietários de imóveis não edificados, localizados em zona de expansão urbana, que cuidarem adequadamente das árvores já existentes ou efetuarem novos plantios em áreas de terrenos de até $7.000 \mathrm{~m}^{2}$, conservados, cercados e protegidos com plantações de árvores nativas, inclusive frutíferas.

Esse mesmo incentivo com redução de 50\% aplica-se também aos imóveis em que seja comprovada a exploração agrícola e agropecuária para o sustento familiar, comprovação esta que pode ocorrer mediante notas fiscais de compra de implementos agrícolas ou laudo técnico expedido por profissional habilitado ou credenciado pelo órgão competente. Não é extensivo aos imóveis com exploração econômica, comercial, de serviço ou industrial.

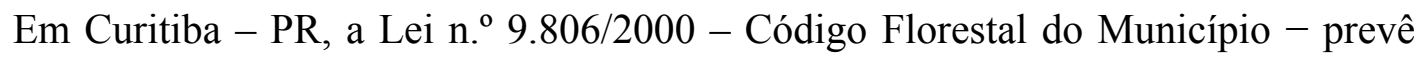
tratamento beneficiado em relação ao IPTU dos contribuintes que tiverem área verde com bosque nativo, pinheiros isolados ou árvores com grande volume de copada, podendo o imposto em tela ser reduzido em até $100 \%$.

As possibilidades de redução são: I - terrenos com bosques não cadastrados pelo município (até 60\%); II - terrenos com árvores consideradas imunes de corte (até 50\%, máximo de 5 árvores); III - terrenos com pinheiros isolados e diâmetro superior a 50 
centímetros na altura do peito (50\%, máximo de 5 árvores); IV - árvore isolada cuja projeção da copada perfaça uma área mínima de $40 \%$ da área total do imóvel (até 50\%).

Contudo, o incentivo acima não será concedido quando as araucárias estiverem dentro de Bosques Nativos Relevantes ou de Bosques Nativos ${ }^{342}$.

Em Manaus - AM, a Lei Municipal n. ${ }^{o}$ 886/2006 veicula incentivo fiscal, segundo a qual seriam parcialmente isentos do pagamento do IPTU os proprietários de imóveis urbanos que conservarem área arborizada.

O incentivo deve ser requerido anualmente e alcança os proprietários de áreas: i) com o mínimo de $2.000 \mathrm{~m}^{2}$, mantidas segundo a legislação vigente, e ii) declaradas de preservação permanente, assim definidas pelo Código Florestal.

O valor total de isenção a ser concedido será entre $10 \%$ e $40 \%$ do valor do IPTU, conforme o percentual de área arborizada.

Já em São Bernardo do Campo, Estado de São Paulo, o incentivo fiscal ambiental possibilita a redução de até $80 \%$ do IPTU incidente sobre a propriedade de imóveis urbanos que possuam cobertura vegetal, desde que haja adimplência dos tributos incidentes sobre os mesmos, em três exercícios consecutivos.

Registre-se que a própria Lei n. ${ }^{\circ}$ 6.091/2010, que institui o incentivo, define cobertura vegetal como aquela que, segundo parecer técnico da Secretaria de Gestão Ambiental, seja representativa da flora regional ou que contribua, de forma significativa, para o índice mínimo de áreas verdes no Município.

Insta registrar que o incentivo em tela não se aplica, em relação a: i) imóvel edificado, cuja área total de terreno for de até $500 \mathrm{~m}^{2}$, qualquer que seja o tamanho da edificação; e ii) imóvel cuja área total edificada supere 1/5 (um quinto) da área total de terreno.

Também o Município de São Vicente - SP, por meio da Lei Complementar n. ${ }^{\circ}$ 634/2010, criou incentivo fiscal ecológico. Com o objetivo de fomentar medidas que

\footnotetext{
${ }^{342}$ Essa mesma lei diferencia conceitualmente os Bosques Nativos dos Bosques Nativos Relevantes, nos parágrafos do seu art. $4 .^{\circ}$ :

$\S 1 .^{\circ}$ Consideram-se Bosques Nativos os maciços de mata nativa representativos da flora do Município de Curitiba, que visem à preservação de águas existentes, do habitat da fauna, da estabilidade dos solos, da proteção paisagística e manutenção da distribuição equilibrada dos maciços florestais.

$\S 2 .^{\circ}$ Consideram-se Bosques Nativos Relevantes aqueles que possuam as características descritas no $\S 1 .^{\circ}$ deste artigo e que pela sua tipologia florestal, localização e porte sejam inscritos no cadastro do Setor Especial de Áreas Verdes, junto à Secretaria Municipal do Meio Ambiente - SMMA.
} 
preservam, protegem e recuperam o meio ambiente, foi instituído o Programa IPTU VERDE, que prevê a redução de alíquotas do Imposto Predial e Territorial Urbano - IPTU, observada a alíquota mínima de $1 \%$.

Para concessão do incentivo, que deve ser requerido anualmente, o proprietário de terrenos não edificados deve aumentar a área permeável, utilizar a área com projetos ecologicamente corretos, como hortas comunitárias, e implantar a calçada ecológica.

Quanto aos imóveis residenciais e não residenciais, os proprietários, para usufruir do incentivo, devem reduzir resíduos; utilizar material sustentável; diminuir o consumo de água e de energia elétrica; ampliar a área permeável.

Além disso, o proprietário/contribuinte deverá estar adimplente com suas obrigações tributárias regulares ou eventual acordo de parcelamento com a municipalidade, sendo alvo de vistoria in loco que ateste as mencionadas condições para a concessão do benefício.

Ainda no Estado de São Paulo, o Município de São Carlos, por meio da Lei Municipal n. ${ }^{\circ}$ 13.692/2005, art. 44, prevê descontos no IPTU aos imóveis edificados que possuírem uma ou mais árvores na calçada em frente ou áreas permeáveis no terreno (jardim ou gramado), sendo o desconto de até 4\% do IPTU a pagar.

Para efeito de desconto no IPTU, valem apenas as árvores plantadas no passeio público (calçada) em frente ao imóvel. Para isso, o morador deve informar o número de árvores existentes na sua calçada, incluindo as palmeiras, coqueiros e semelhantes.

De sua parte, a Lei do Município de Guarulhos, que versa sobre o lançamento, arrecadação e fiscalização do IPTU, tem capítulo específico para os incentivos ambientais (Lei Municipal n. ${ }^{\circ}$ 6.793/2010).

Nesse capítulo é instituída isenção do IPTU no que tange às áreas de preservação ambiental permanente, desde que seja comprovada a efetiva preservação por laudos técnicos apresentados pelos proprietários ou responsáveis, devidamente averbados no Cartório de Registro de Imóveis, na forma e prazos previstos em regulamento.

São também concedidos descontos, de até $20 \%$, do valor do IPTU anual devido, pelo período de 5 exercícios consecutivos, para os imóveis edificados que adotarem duas ou mais ações/medidas elencadas na lei. 
Cada uma das medidas tem um percentual de redução (entre 3\% e 5\%), as quais, se acumuladas, poderão reduzir até o citado teto legal. Como exemplos das ações estimuladas pelo aludido diploma legal, verifica-se a existência de sistema de captação da água da chuva (3\%), reúso de água (3\%), utilização de energia eólica $(5 \%)$, dentre outros.

Há ainda a concessão de descontos de até $2 \%$ para os proprietários de imóveis que possuam árvores dos tipos adequados à arborização de vias públicas, ou preservação de árvore já existente, bem assim possuam no perímetro de seu terreno áreas efetivamente permeáveis, com cobertura vegetal, observando-se a manutenção de área suficiente para sua irrigação, na forma do regulamento.

A fixação do valor do desconto considerará o tamanho da área permeável em relação ao tamanho do lote e a localização do imóvel dentro do perímetro urbano, na forma do regulamento.

Vale consignar que, na capital do Rio de Janeiro, encontra-se em tramitação o Projeto de Lei n. ${ }^{\circ} 1.415 / 2012^{343}$, que concede tratamento fiscal diferenciado, no âmbito do ISS, IPTU e também do ITBI, para empreendimentos que detenham qualificações ecologicamente incentivadas. Estabelece, também, incentivos fiscais para os projetos de novas edificações e edificações existentes, de uso residencial, comercial, misto ou institucional, que detenham a qualificação "qualiverde" ou "qualiverde total".

Tal certificação é concedida pela Prefeitura da Cidade do Rio de Janeiro, quando preenchidas as exigências nos termos estabelecidos em regulamentação específica.

Nas edificações que obtiverem a qualificação "qualiverde" não serão admitidas obras que descaracterizem as ações de sustentabilidade que justificaram a qualificação, nem atividades comerciais que causem incômodo ou prejuízo à vizinhança e ao meio ambiente, devendo ser mantidas ou melhoradas as condições existentes.

Assim, no âmbito do ISS, haverá tratamento tributário diferenciado em relação aos serviços relacionados na Lista de Serviços da Lei Complementar n. ${ }^{\circ}$ 116/2003, nos itens 7.02 e $7.05^{344}$.

\footnotetext{
${ }^{343}$ Projeto de Lei n. ${ }^{\circ} 1.415 / 2012 /$ RJ. RIO DE JANEIRO. Assembleia Legislativa. Projeto de Lei ${ }^{\circ}{ }^{\circ}$ 1.415/2012. Estabelece benefícios fiscais para os empreendimentos que detenham qualificação Qualiverde e dá outras providências. Disponível em: $<$ http://mail.camara.rj.gov.br/APL/Legislativos/scpro0711.nsf/1061f759d97a6b24832566ec0018d832/071a ea683fd2bbbb03257ald0071dcf7?OpenDocument>. Acesso em: 3 set. 2012.

3447.02 - execução, por administração, empreitada ou subempreitada, de obras de construção civil, hidráulica ou elétrica e de outras obras semelhantes, inclusive sondagem, perfuração de poços, escavação, drenagem e
} 
Para esses serviços, quando houver a qualificação "qualiverde", a alíquota incidente será de $1,5 \%$, e quando houver a qualificação "qualiverde total", de $0,5 \%$.

No caso do ITBI, é prevista a redução de $50 \%$ do imposto devido quando houver a qualificação "qualiverde" e a isenção quando houver a qualificação "qualiverde total”.

Importante registrar, entretanto, que os mencionados benefícios serão concedidos somente ao adquirente final, uma única vez.

No que toca ao IPTU, os benefícios serão distintos durante a construção do empreendimento e após o habite-se.

Assim, durante a construção, o IPTU será reduzido em $50 \%$ quando houver a qualificação "qualiverde”, sendo prevista a isenção do imposto na hipótese da qualificação "qualiverde total".

Após o habite-se, será minorada em $10 \%$ a cobrança do imposto quando houver a qualificação "qualiverde", e em $20 \%$ quando houver a qualificação "qualiverde total". A concessão desse desconto terá validade de três anos, sendo então reavaliado pelas Secretarias Municipais de Urbanismo, de Meio Ambiente e de Fazenda, podendo ser renovado o incentivo.

\subsubsection{Incentivos fiscais ambientais no Direito comparado}

Cumpre abordar, nesta altura, a aplicação do instituto em voga pelos diversos países. Consoante se perceberá, os países vêm adotando, na sua maioria, redução de alíquotas ou isenções tributárias para produtos de reduzido impacto ambiental, possibilidade de dedução do IRPJ ou do IRPF para certos gastos com bens ou serviços ambientalmente orientados e depreciação acelerada para investimentos em capital relacionados à sustentabilidade (bens de capitais que geram energia limpa ou conservam energia, por exemplo).

irrigação, terraplanagem, pavimentação, concretagem e a instalação e montagem de produtos, peças e equipamentos (exceto o fornecimento de mercadorias produzidas pelo prestador de serviços fora do local da prestação dos serviços, que fica sujeito ao ICMS);

7.05 - reparação, conservação e reforma de edifícios, estradas, pontes, portos e congêneres (exceto o fornecimento de mercado rias produzidas pelo prestador dos serviços, fora do local da prestação dos serviços, que fica sujeito ao ICMS). 
Com efeito, na Áustria ${ }^{345}$, a tentativa de influenciar condutas cada vez mais sustentáveis para o meio ambiente tem ensejado a formulação de incentivos fiscais ambientais em relação a operações negociais mais verdes e a aquisições de meios de transportes movidos a eletricidade.

Desse modo, o tributo chamado VAT (Value added tax), traduzido como Imposto sobre Valor Agregado, equiparado no Brasil ao ICMS, pode ser reduzido com o escopo de induzir as empresas e cidadãos a escolher operações mais limpas em suas rotinas.

Um dos mecanismos de cobrança desse imposto, na Áustria, dá-se por intermédio do denominado Sistema de Cobrança Reversa, a partir do qual, sob certas condições, a obrigação de pagá-lo é deslocada ao destinatário da operação. Para este destinatário é prevista a dedução do VAT, desde que opere em condições negociais mais verdes, definidas pela legislação local.

Outro incentivo é verificado na aquisição de carros elétricos ou eletro-hidráulicos. Nesse país, é exigido um tributo denominado NOVA na aquisição de automóveis de passeio e motocicletas ainda não registrados nacionalmente, incidente sobre o preço de compra ou sobre a taxa de arrendamento mercantil. Contudo, há isenções em determinadas situações, como nas aquisições de carros de autoescolas, táxis, ambulâncias, automóveis para uso diplomático, para pessoas com deficiência, e, principalmente, para a aquisição de veículos e/ou motocicletas elétricos ou eletro-hidráulicos, sendo incentivada nestes dois últimos casos a redução da utilização de combustíveis poluentes.

No Canadá ${ }^{346}$ são ainda mais variados os incentivos fiscais ambientais. Dentre eles estão os incentivos relativos ao Imposto de Renda, mediante a utilização pelos cidadãos e empresas de determinados bens previamente classificados como ecologicamente aceitáveis e por meio da pesquisa científica ou seu investimento.

Nesta senda, existe a possibilidade de deduzir, anualmente, $50 \%$ do Imposto de Renda por força das aquisições de equipamentos (custo de capital), antes de 2020, que gerem calor ou energia para uso no processo industrial, por meio da utilização de uma fonte renovável de energia que reutilize combustíveis fósseis ou que faça uso eficiente desses combustíveis. Para tanto, os equipamentos foram numerados e classificados em: Equipamentos para geração de energia limpa (Classe 43.2); Equipamentos para

\footnotetext{
${ }^{345}$ Maiores informações em AUSTRALIAN GOVERNMENT. Australian Taxation Office. Disponível em: $<$ http://www.ato.gov.au $>$.

${ }^{346}$ CANADA REVENUE AGENCY. Disponível em: <http://www.cra-arc.gc.ca/>. Acesso em: 15 jul. 2012.
} 
conservação de energia (Classe 43.1); Tubulações de dióxido de carbono; Equipamentos de bombeamento e compressão de tubulações de dióxido de carbono (Classe 7).

Há, também, a possibilidade de deduzir do Imposto de Renda despesas com renovação e conservação para o desenvolvimento de projetos (de estudos de viabilidade, engenharia, design etc.) que utilizem bens classificados como equipamentos de geração de energia limpa ou equipamentos de conservação de energia, não havendo, neste caso, valor máximo de dedução prevista em lei.

Ainda quanto aos incentivos relativos ao Imposto de Renda nesse país, é possível deduzir fiscalmente despesas com a Pesquisa Científica e Desenvolvimento Experimental (Scientific Research and Experimental Development - SR\&ED), não havendo, também, valor máximo de dedução definido em lei, bastando que os projetos sejam especificamente de "pesquisa básica", "pesquisa aplicada" ou de "desenvolvimento experimental".

O investimento em Pesquisa Científica é incentivado por meio de créditos fiscais para investimento em SR\&ED - ITC (Investment Tax Credit), disponíveis mediante qualificação de despesas atuais de capital incorridas em SR\&ED no país, incluindo salários pagos a pesquisadores que se encontram no exterior. Os ITCs (considerados créditos fiscais) corresponderão a $20 \%$ das despesas elegíveis. Para empresas cujo controle privado seja canadense, os incentivos correspondem a 35\% das despesas, tendo um valor máximo correspondente a \$ 3 milhões.

Na Holanda ${ }^{347}$, o IRPF abarca os rendimentos da poupança e investimentos, sendo baseado em um valor fixo e calculado sobre o valor médio das poupanças e investimentos.

No entanto, quando o particular investe em instituições que, por sua vez investem em projetos ambientais, como energia renovável, agricultura biológica, projetos florestais, o particular tem direito a "isenção sobre Investimentos Verdes". De modo que, os rendimentos decorrentes desses investimentos verdes não são levados em conta, figurando como uma espécie de dedução, no cálculo do Imposto de Renda, até o montante de $56.420 €$.

Na França ${ }^{348}$ existem diversos tributos relacionados a veículos, sua potência e seus combustíveis. Como contraponto a essa tributação, há previsão de incentivos fiscais na forma de isenções e reduções do imposto a pagar em hipóteses de carros considerados limpos, que utilizem biocombustíveis (total ou parcialmente).

\footnotetext{
${ }^{347}$ BELASTINGDIENST. Disponível em: $<$ http://www.belastingdienst.nl>. Acesso em: 15. 2012.

${ }^{348}$ LEGIFRANCE. Disponível em: < http://www.impots.gouv.fr>. Acesso em: 15. 2012.
} 
Ainda na França, o Imposto Geral sobre Atividades Poluidoras tem previsão de isenção em relação a lubrificantes biodegradáveis.

Esse mesmo país fornece crédito fiscal aos particulares nas despesas com equipamentos para residências, cujas alíquotas variam entre $10 \%$ e $32 \%$, de acordo com a natureza dos gastos (por exemplo, o sistema fotovoltaico, turbinas eólicas, bombas de sistemas de aquecimento determinadas, o isolamento térmico, tratamento de água da chuva, instalações de aquecimento).

Por sua vez, as empresas que utilizam o sistema fotovoltaico poderão abater do imposto sobre a propriedade até o limite do valor da instalação fotovoltaica.

Já na Itália ${ }^{349}$, há incentivos fiscais para painéis solares e para energias renováveis. Consta, também, incentivo para a melhora da eficiência energética de construções já existentes e de todas as obras que aumentam a eficiência energética destas construções (não aplicável a novas construções). Nos três casos, o estímulo é válido para pessoas físicas e jurídicas.

Especificamente no caso de requalificação energética de construções existentes, há autorização para dedução fiscal de 55\% dos custos incorridos pelo contribuinte, desde que haja redução de consumo de energia primária para aquecimento anual de inverno em pelo menos $20 \%$ dos valores registrados em gráfico especial.

Para tanto, o pagamento dessas despesas deve ser feito por meio de transferência bancária ou postal, e como prova deve ser obtido o certificado de energia do edifício, se este foi introduzido pela região ou autoridade local. Caso contrário, deve ser providenciado um "certificado de eficiência energética", elaborado por um profissional certificado.

Ademais, a substituição de refrigeradores poluentes permite que os consumidores recebam um crédito fiscal para as compras de refrigeradores e congeladores com energia eficiente, concedido apenas em caso de substituição do antigo aparelho.

$\mathrm{Na}$ Inglaterra ${ }^{350}$, é possível identificar uma série de incentivos relacionados ao meio ambiente. Citam-se os principais, com seus respectivos mecanismos e requisitos.

Em 2001, objetivando incentivar a recuperação de áreas afetadas por contaminação pelo uso industrial, esse país criou um regime conhecido como "LRR” (Land Remediation

\footnotetext{
349 AGENZIA DEL TERRITORIO NELL'AGENZIA DELLE ENTRATE. Disponível em: $<$ http://www.agenziaentrate.gov.it $>$. Acesso em: 18 nov. 2012.

${ }^{350}$ HM REVENUE \& CUSTOMS. Disponível em: <http://www.hmrc.gov.uk/>. Acesso em: 15 out. 2012.
} 
Relief Scheme), que em português pode ser chamado de Recuperação de Áreas Contaminadas. O regime foi ampliado em 2009 para incluir áreas abandonadas, bem como a remoção em áreas de ocorrência natural de radônio, arsênico e knotweed japonês (ervado-nó). O regime "LRR" permite que as empresas deduzam um montante igual a $150 \%$ do custo da limpeza ao calcular seus lucros tributáveis para fins do Imposto de Renda.

Existe, ainda, o incentivo fiscal no âmbito do imposto sobre a mudança climática ("CCL" - Climate Change Levy - United Kingdom), que, como já dito, incide sobre a energia (eletricidade, gás, combustível sólido e gás liquefeito) adquirida por consumidores não domésticos.

Para fruição do citado incentivo, são necessários acordos sobre mudanças climáticas ("CCA" - Climate Change Agreement - United Kingdom) que, por sua vez, fornecem um mecanismo para que grandes empresas consumidoras de energia recebam um desconto do "CCL". Esses acordos voluntários são discutidos por toda a indústria com o secretário de Estado de Energia e Alterações Climáticas (acordos atuais incluem o setor de produtos químicos). Esses "CCAs" obrigam as empresas com grandes instalações e elevado consumo de energia a cumprir metas para melhorar a sua eficiência energética e reduzir as emissões de dióxido de carbono, com a contrapartida da redução do imposto "CCL" a pagar.

O atual percentual de desconto é de $65 \%$. O governo do Reino Unido ${ }^{351}$ anunciou, no Orçamento de 2011, que o desconto seria aumentado de $65 \%$ para $80 \%$ em abril de 2013. No entanto, na Declaração de Outono de 2011, o governo informou que o aumento alcançaria $90 \%$ a partir de $1 .^{\circ}$ de abril de 2013.

Além disso, para incentivar a geração de eletricidade renovável, a energia produzida a partir de determinadas fontes renováveis pode ser isenta do "CCL". A isenção ocorre quando a energia fornecida pelas empresas provém de uma fonte renovável. Para tanto, o governo criou um certificado a fim de identificar as fontes renováveis, o Certificado de Isenção de Arrecadação ("LEC"). Para cada megawatt-hora de eletricidade gerada por um gerador que produz energia certificada renovável, o governo emite um "LEC" garantidor da referida isenção.

${ }^{351}$ HM REVENUE \& CUSTOMS. Disponível em: <http://www.hmrc.gov.uk/>. Acesso em: 15 out. 2012. 
A previsão é de que esses acordos expirem em 2013, mas o governo do Reino Unido $^{352}$ já tem elaborado um regime de revisão e expansão deles até o prazo previsto (2013).

Consta, também, a Isenção de Capital para Investimento em Tecnologias Ambientais. Nesse programa, as empresas têm direito a uma isenção anual de 100\% (“AIA") para a maior parte de seu investimento em instalações e máquinas com tecnologias ambientais, até um limite definido. O investimento na qualificação de máquinas e equipamentos permite que se pleiteie uma dedução "melhorada" ("FYA"). Alguns tipos de "FYA" foram agora substituídos pela "AIA". No entanto, como parte das políticas do Governo britânico de mudança climática, as "FYA" ainda estão disponíveis em 100\% para as despesas com "tecnologia de qualificação" que promovam a economia de energia ou outros benefícios ambientais ("ECA").

A "ECA"possibilita que as empresas amortizem a totalidade do custo de capital do seu investimento em certos tipos de instalações e máquinas, com relação aos lucros tributáveis do período em que são adquiridas. Os seguintes tipos de instalações e máquinas são "tecnologia qualificadora": máquinas e instalações que economizem energia; máquinas e instalações ambientalmente benéficas; carros com baixas emissões de dióxido de carbono; e equipamentos reabastecidos com gás natural, biogás e hidrogênio.

A par dos aludidos incentivos fiscais, muitos governos optam pelo manejo de instrumentos financeiros voltados ao estímulo de práticas tendentes à preservação do meio ambiente, os quais, ainda que não se enquadrem como incentivos fiscais, merecem destaque.

Nesta linha, o Canadá ${ }^{353}$ destina financiamentos a empresas nacionais de responsabilidade limitada visando à elaboração de pesquisa e desenvolvimento de nanoprodutos por meio do uso de nanotecnologia ${ }^{354}$ e de materiais sustentáveis retirados

\footnotetext{
${ }^{352}$ HM REVENUE \& CUSTOMS. Disponível em: <http://www.hmrc.gov.uk/>. Acesso em: 15 out. 2012.

${ }^{353}$ CANADA REVENUE AGENCY. Disponível em: <http://www.cra-arc.gc.ca/>. Acesso em: 15 out. 2012.

354 "A nanotecnologia (algumas vezes chamada de Nanotech) é o estudo de manipulação da matéria numa escala atômica e molecular. Geralmente lida com estruturas com medidas entre 1 a 100 nanômetros em ao menos uma dimensão, e incluí o desenvolvimento de materiais ou componentes e está associada a diversas áreas (como a medicina, eletrônica, ciência da computação, física, química, biologia e engenharia dos materiais) de pesquisa e produção na escala nano (escala atômica). O princípio básico da nanotecnologia é a construção de estruturas e novos materiais a partir dos átomos (os tijolos básicos da natureza). [...] A nanotecnologia é a capacidade potencial de criar coisas a partir do menor elemento, usando as técnicas e ferramentas que estão a ser desenvolvidas nos dias de hoje para colocar cada átomo e cada molécula no lugar desejado. Se conseguirmos este sistema de engenharia molecular, o resultado será uma nova revolução industrial. Além disso, teria também importantes consequências econômicas, sociais, ambientais e militares" (NANOTECNOLOGIA. Disponível em: <http://pt.wikipedia.org/wiki/Nanotecnologia>. Acesso em: 27 fev. 2012).
} 
das florestas canadenses. Os projetos devem desenvolver objetivos específicos e ser aprovados pelo Conselho da Rede ArboraNano ${ }^{355}$. O valor do financiamento será determinado pelo Comitê Científico da Rede ArboraNano, e o pagamento ocorrerá em intervalos de seis meses, condicionado a relatórios de satisfação.

Há também, no Canadá ${ }^{356}$, financiamento específico para a inovação automotiva, por meio de contribuições reembolsáveis concedidas a empresas deste ramo que estejam estabelecidas no território nacional. O apoio é focado na produção estratégica e de larga escala, envolvendo produtos automotivos e/ou programas de pesquisa e desenvolvimento de projetos para a fabricação de veículos inovadores, verdes e mais econômicos. As empresas interessadas devem estar munidas de propostas para investimentos no setor privado do Canadá ${ }^{357}$ que excedam $\$ 75$ milhões ao longo de 5 anos. Os projetos escolhidos devem requerer o financiamento governamental e apresentar um cronograma de implantação em até 5 anos. O valor limitado pelo financiamento do programa é de \$250 milhões ao longo desses 5 anos.

$\mathrm{Na}$ seara dos biocombustíveis, o país prevê o financiamento de "Next Gen Biocombustíveis", voltado ao desenvolvimento e à produção de biocombustíveis que usem processos de "próxima geração". Portanto, para haver o financiamento, os projetos devem ser desenvolvidos em centros industriais canadenses produtores de combustíveis renováveis de próxima geração (ex.: etanol ou biodiesel) em larga escala, que usem estoques representativos para a biomassa do país e que estejam prontos em até seis anos. Baseado em fluxo de caixa, o financiamento de até $40 \%$ dos custos do projeto, limitado a $\$$ 200 milhões, será reembolsável após 10 anos da finalização do projeto.

A tecnologia que envolve soluções verdes (mudança global, ar limpo, água e qualidade do solo) é alvo de financiamentos anuais que apoiam o estado tardio de desenvolvimento e a demonstração pré-comercial de tal tecnologia. Assim, para fazer jus ao financiamento, limitado a $50 \%$ dos custos do projeto, é preciso que as tecnologias sejam aplicáveis em setores canadenses específicos, apresentem forte relevância de mercado e incrementem a propriedade intelectual.

\footnotetext{
355 Trata-se de rede de pesquisa e desenvolvimento voltada à criação da nova economia verde no Canadá, por meio da inovação, engenharia de ponta, nanotecnologia, produtos com emissões de carbono neutralizadas oriundos dos recursos das florestas canadenses (VISION \& Objectives. Disponível em: $<$ http://www.arboranano.ca/vision-objectives.aspx>. Acesso em: 12 nov. 2012).

${ }^{356}$ CANADA REVENUE AGENCY. Disponível em: <http://www.cra-arc.gc.ca/>. Acesso em: 12 nov. 2012. ${ }^{357}$ Id. Ibid.
} 


\subsection{Limitações à concessão de incentivos fiscais ambientais}

\subsubsection{Competência para a instituição de incentivos fiscais ambientais}

Consignou-se linhas acima que a Constituição Federal de 1988 autorizou a criação de incentivos fiscais ambientais, veiculados por meio de lei específica, da lavra da pessoa jurídica de direito público competente para instituir a correlata imposição fiscal, os quais se submetem aos mesmos princípios e regras norteadores do poder de tributar.

Pontuou-se, ainda, que os entes arrecadantes, dentro da esfera de sua competência tributária, só podem regular condutas, mediante incentivos fiscais, em relação a matérias em que detenham competência legislativa.

Considerando-se tais premissas, passa-se a analisar em que medida a União, os Estados e os Municípios podem atuar, concedendo estímulos fiscais atrelados à defesa do meio ambiente.

Acerca da proteção do meio ambiente, verifica-se, da análise da Constituição Federal de 1988, que esta, ao distribuir as competências legislativas materiais entre os entes políticos, estabeleceu em seu art. 23 ser de competência comum da União, Estados, Distrito Federal e Municípios: VI - proteger o meio ambiente e combater a poluição em qualquer de suas formas; VII - preservar as florestas, a fauna e a flora; etc.

Por seu turno, no bojo do art. 24, atribuiu competência concorrente para a União, os Estados e o Distrito Federal legislarem concorrentemente sobre diversas matérias, dentre elas: VI - florestas, caça, pesca, fauna, conservação da natureza, defesa do solo e dos recursos naturais, proteção do meio ambiente e controle da poluição etc.

Neste contexto, uma vasta gama de políticas públicas pode ser criada pelas pessoas políticas nacionais, com o intuito de concretizar a defesa e conservação do meio ambiente, sendo, todavia, de incumbência da União a elaboração de normas gerais sobre a matéria vertente, de caráter nacional e com efeito vinculante em relação aos Estados, Distrito Federal e Municípios.

Vale registrar que, no tocante a alguns temas específicos, tais como atividades nucleares, águas e recursos minerais, optou o legislador por inseri-los no rol de 
competência privativa da União (art. 22 da CF/1988), retirando-os, assim, do âmbito legislativo dos Estados, Distrito Federal e Municípios.

Neste contexto, dúvidas surgem quanto à possibilidade de um Estado da Federação instituir incentivo fiscal com o intuito de estimular comportamento ambientalmente orientado no âmbito da sua competência, porém abarcando atividade cuja disciplina se encontra fora da sua esfera de competência legislativa material.

Ilustrativamente, questiona-se: poderia o Estado reduzir a base de cálculo do ICMS incidente sobre equipamentos ecoeficientes adquiridos por certa usina nuclear? Estaria tal ente, a pretexto de estimular condutas que impactam positivamente o ambiente, regulando atividade cuja competência para legislar é da União?

A esse respeito, Luís Eduardo Schoueri ${ }^{358}$, em artigo intitulado "Normas tributárias indutoras em matéria ambiental", considerando que existem casos em que os Estados e os Municípios possuem atuação limitada, em virtude de a regulação da matéria encontrar-se no campo de competência exclusiva da União, teceu a seguinte ponderação: "parece-nos que não poderiam aquelas Pessoas Jurídicas de Direito Público, valendo-se de sua competência tributária, regular, por meio de tributo, o que não poderia ser regulado por norma direta".

Acerca de tal ponderação, é importante esclarecer que as matérias de competência privativa da União não podem ter seus contornos delineados ou alterados por políticas fiscais dos demais entes. Não há impedimento jurídico, todavia, para que tais entes, por serem dotados de competência comum para a defesa do meio ambiente, desonerem total ou parcialmente uma atividade lícita, regulamentada exclusivamente pela União, em função de um ganho ambiental.

Nesta linha de raciocínio encontra-se Terence Dorneles Trennepohl ${ }^{359}$, para quem “tanto a União quanto os Estados e Municípios podem empregar esforços no sentido de desonerar aquelas condutas mais aptas ao atendimento do desiderato ambiental. As competências de cada qual, sejam elas legislativas e/ou materiais, tanto tributárias quanto ambientais, dão margem à adoção de benefícios”.

De tal sorte, afigura-se lícito que um Estado da federação reduza, total ou parcialmente, o ICMS incidente sobre a aquisição de bens ecoeficientes por determinada

\footnotetext{
${ }^{358}$ SCHOUERI, Luís Eduardo. Normas tributárias indutoras em matéria ambiental, cit., p. 251.

359 TRENNEPOHL, Terence Dorneles. Incentivos tributários e meio ambiente: a sustentabilidade ambiental e o direito tributário, cit., p. 365.
} 
usina de energia nuclear que se instala em seu território. Ou ainda, por força da adesão desta última a programa que promova a educação ambiental, reduza a base de cálculo do citado imposto em relação aos insumos adquiridos.

Assim, muito embora a atividade nuclear deva ser disciplinada, de forma exclusiva, pela União, o ente político, movido pelo objetivo de preservação do meio ambiente, pode fomentar, mediante tratamento fiscal mais vantajoso, a utilização de bens mais sustentáveis e a difusão da educação ambiental, sem com isto estar a disciplinar matéria excluída da sua competência legislativa material.

Portanto, uma vez sendo determinada atividade considerada lícita pelo ente competente para discipliná-la, e desde que o incentivo fiscal que a alcance esteja atrelado à proteção ambiental cuja competência para legislar é comum, não há vedação à sua concessão pelos entes da federação.

Nesta senda, cabe destacar precedente do STF, por meio do qual foi declarada constitucional a taxa de fiscalização florestal instituída por Estado da Federação, ainda que a autorização para legislar sobre "florestas", nos termos do art. 8. , inciso XVII, alínea "h", da Constituição de 1969, vigente à época, fosse concedida apenas à União.

O mencionado Tribunal Superior, a despeito da aludida restrição legislativa de cunho material, defendeu que a taxa em foco, por cristalizar o poder de polícia do Estado (art. 18, I, CF/1969), voltado à fiscalização de um interesse comum, que seria a proteção e manutenção das florestas ${ }^{360}$, poderia ser instituída:

Taxa. Seu conceito (art. 18, inc.I, da Constituição). Taxa Florestal instituída pelo Estado de Minas Gerais (Lei n. ${ }^{\circ}$ 7.163/1977). A competência da união para legislar sobre florestas não exclui a competência tributária do Estado-membro, como se dá nas circunstâncias do caso, em razão do exercício do poder de polícia administrativa. Interesse comum na preservação das florestas. Na espécie o tributo em questão, exigido das pessoas ligadas a atividades fiscalizadas pelo Estado e destinado ao seu custeio, situa-se como taxa de polícia. Improcedência da representação.

Portanto, mesmo sob a égide da Constituição de 1969, em que a competência legislativa se achava mais concentrada na União, não se afastou, de plano, a possibilidade

${ }^{360}$ STF, Representação n. ${ }^{\circ}$ 1.008/MG, Rel. Min. Djaci Falcão, Tribunal Pleno do STF, j. 27.08.1981. Disponível

em:

$<$ http://www.stf.jus.br/portal/jurisprudencia/listarJurisprudencia.asp?s1=\%28Rp $\% 24 \% 2 \mathrm{ESCLA} \% 2 \mathrm{E}+\mathrm{E}+10$ 08\%2ENUME $\% 2 \mathrm{E} \% 29+\mathrm{OU}+\% 28 \mathrm{Rp} \% 2 \mathrm{EACMS} \% 2 \mathrm{E}+\mathrm{ADJ} 2+1008 \% 2 \mathrm{EACMS} \% 2 \mathrm{E} \% 29 \&$ base=baseAcor daos>. Acesso em: 16 jan. 2012. 
de instituição de taxa que recai sobre matéria de competência exclusiva do referido ente. Há de ser avaliado, em cada caso, o contexto da norma tributária ou do incentivo fiscal, para se identificar se o ente político invadiu a competência de outro ente, via tributação, ou atuou no âmbito da sua competência, como no caso da jurisprudência acima mencionada.

Com efeito, uma vez que o ordenamento jurídico atual estipula que a proteção ambiental é matéria a ser disciplinada por todos os entes, cabendo à União estabelecer regras gerais vinculantes, é possível, por exemplo, a concessão de incentivos físcais ambientais relacionados a atividade cuja regulação seja exclusiva da União, desde que o tratamento tributário vantajoso concedido a tal atividade esteja efetivamente atrelado ao fomento de comportamento ambientalmente orientado, e não vinculado à disciplina, em si, da referida atividade.

Conclui-se, pois, ser vedada apenas a concessão de incentivo fiscal que, a pretexto de defender o meio ambiente, pretende invadir a competência exclusiva de outro ente político mediante a regulamentação, por vias transversas, da atividade que se encontra fora da sua alçada, o que, na prática, consubstancia verdadeira distorção.

\subsubsection{A legalidade aplicada aos incentivos fiscais ambientais}

Já restou consignado que a legalidade tributária estipula que o tributo deve estar previsto em lei, nesta devendo constar o fundamento e demais critérios de decisão do respectivo ato de aplicação (lançamento tributário), evitando, assim, que se conceda margem ao arbítrio do administrador.

Trazendo o foco para a concessão de incentivos fiscais ambientais, verifica-se que, além da indispensável lei específica - federal, estadual ou municipal - que regula, exclusivamente, a criação de tais estímulos tributários ( $§ 6 .^{\circ}$ do art. 150 da CF), necessário se faz que essa norma legal albergue comando voltado ao atingimento de um fim constitucional, especialmente por esta se encontrar no âmbito da extrafiscalidade, possuindo função indutora de comportamentos ambientalmente responsáveis.

Assim, uma vez que as questões ambientais se encontram atreladas à realidade econômica e tecnológica, de intensa mutabilidade, as normas instituidoras de incentivos ambientais devem ser cunhadas de modo a se ajustar a tais mudanças. 
De fato, um limite legal de emissão torna-se obsoleto tão logo se identifique tecnologia que permita o desenvolvimento de atividade com impacto ambiental mais reduzido. Ademais, o avanço de tecnologias alternativas pode permitir que certo modo de produção neutro em emissões, antes economicamente inviável, torne-se factível, bem como pesquisas podem revelar que determinada atividade tida como de baixo impacto ambiental afigura-se altamente impactante.

Diante de tais variáveis, defende-se, na esfera ambiental, o manejo ainda mais robusto de conceitos indeterminados e de cláusulas gerais, que já são bem utilizados em normas tributárias que veiculam incentivos fiscais.

Lastreada no mencionado recurso, a Lei da Política Nacional do Meio Ambiente, de n. ${ }^{\circ}$ 6.938/1981, por meio do seu art. 9. ${ }^{\circ}$, estipula como instrumento da Política Nacional do Meio Ambiente: "V - os incentivos à produção e instalação de equipamentos e a criação ou absorção de tecnologia, voltados para a melhoria da qualidade ambiental”.

Com efeito, a previsão legal em pauta alberga a expressão "melhoria da qualidade ambiental", cuja abertura irá permitir que se criem os mais diversos incentivos, incluindo os tributários, voltados ao incremento das condições do meio ambiente, bem como reduzindo as emissões poluentes e elevando a cobertura florestal.

Outro aspecto a ser ressaltado é que poderá a lei específica instituidora do incentivo fiscal ambiental remeter à norma infralegal a especificação da conduta incentivada, sem que isto resulte em transgressão da legalidade.

Deveras, o que poderia ser considerado uma fraude ao dever de legalidade seria uma delegação aberta aos Executivos federal, estadual e municipal, uma verdadeira "carta branca" na qual estes se achassem livres para cunhar as linhas estruturantes do incentivo. A permissão para esmiuçar, detalhar as atividades, os produtos, os serviços e os agentes incentivados encontra-se em perfeita sintonia com o primado em foco, especialmente em se tratando da matéria ambiental, rica em particularidades a serem detalhadas em sede própria.

As inúmeras especificidades inerentes à questão ambiental irão, muitas vezes, demandar que um órgão técnico avalie o atendimento às imposições legais pelo contribuinte, hipótese em que o deferimento do incentivo poderá estar condicionado a reconhecimento expresso a ser veiculado por ato normativo da lavra de órgão ligado ao Poder Executivo. 
Neste prisma, a multicitada Lei da Política Nacional do Meio Ambiente, ao versar sobre incentivos criados para fins de proteção ambiental, atrela a aprovação dos respectivos projetos que buscam o incentivo ao atendimento de requisitos e comandos emitidos por órgãos especializados. É o que se depreende do artigo 12 do referido diploma legal, segundo o qual "as entidades e órgãos de financiamento e incentivos governamentais condicionarão a aprovação de projetos habilitados a esses benefícios ao licenciamento, na forma desta Lei, e ao cumprimento das normas, dos critérios e dos padrões expedidos pelo CONAMA".

Com efeito, uma vez sendo fixada, pela lei instituidora do estímulo fissal, a previsão de qual ato normativo irá regulamentar certos aspectos desta ou qual ato de determinado órgão especializado será requisito para a homologação do incentivo, e havendo obediência aos limites impostos pelo diploma legal, não há que se falar em violação ao primado da legalidade, mas em harmônica conjugação de normas, que irá possibilitar o alcance da função indutora de comportamentos ambientalmente orientados.

Portanto, pode-se concluir que a legalidade, no âmbito da concessão de incentivos fiscais ambientais, não pode ser aplicada com o viés estritamente formalista, pois isso impediria a materialização do próprio escopo do tratamento fiscal mais benéfico para aqueles que se pautam em condutas ambientalmente responsáveis.

Dito de outro modo, a aplicação formalista da legalidade impedirá a concretização do objetivo da norma de estimular condutas protetoras do meio ambiente, devendo, pois, ser afastada.

\subsubsection{Igualdade e proporcionalidade na instituição de incentivos fiscais ambientais}

Já restou firmado que, quando a concretização de determinado objetivo constitucional justificar um tratamento fiscal diferenciado, a generalidade e a uniformidade da tributação poderão ser relativizadas, não constituindo ofensa à igualdade caso a discriminação realizada passe no teste da proporcionalidade.

Considerando que a proteção do meio ambiente consubstancia vetor constitucional que pode ensejar uma discriminação legal na forma de incentivos fiscais ambientais, passase a examinar parâmetros a serem observados para que seja atendido o princípio da 
igualdade. Afinal de contas, não basta que se busque a concretização de um objetivo nobre, que é a defesa do meio ambiente, com expressa permissão constitucional; é indispensável que o instrumento criado com tal intuito se ache ajustado, de forma proporcional, a outros bens, valores e objetivos constitucionais.

Calibrar as mais variadas diretrizes constitucionais que entram em choque concretamente quando se institui um incentivo fiscal ambiental não é tarefa simples, especialmente quando se soma a tal dificuldade o fato de que todas as conclusões a que se chega ao campo da proteção do meio ambiente exigem análises e comparações técnicas e econômicas concretas.

Dentro de tal perspectiva, para compreensão do presente tópico, importante se ter em mente a premissa de que a questão da proteção ambiental é, por si só, de complexa identificação, demandando profundo estudo, que envolve todo o ciclo de vida do produto, modo de produção e serviço investigado, para se constatar de que forma é possível alcançar um efetivo ganho ambiental.

Em alguns casos, não há dúvidas quanto ao ganho ambiental, a exemplo da preservação de árvores num terreno, proteção de espécies da fauna e da flora em extinção. Contudo, casos há em que, à primeira vista, é possível cogitar que determinado bem é mais sustentável do que outro, por ser dotado de características comumente atreladas à menor degradação do meio ambiente, mas uma investigação técnica mais apurada pode evidenciar exatamente o contrário.

Tomando-se, por exemplo, a comparação entre paletes (suporte utilizado para movimentação de cargas) feitos de plástico e de madeira, tem-se, num primeiro momento, que o suporte de madeira produz menor impacto ambiental; todavia, quando se considera o acentuado peso do produto de madeira, o combustível que esse peso irá demandar no seu transporte, a sua durabilidade, dentre outros aspectos, chega-se à conclusão de que o uso do palete de plástico é, para tal fim, mais vantajoso em termos ambientais.

Assim sendo, a primeira medida que se deve adotar é verificar se o tratamento vantajoso que alcançará o bem, serviço ou meio de produção eleito pela norma tributária promove um real ganho ambiental, sendo, para tanto, indispensável a análise técnica do seu balanço energético, ciclo de vida, dentre outras avaliações, que conclua pela sua vantagem para o meio ambiente. 
Uma vez comprovado que o substrato sobre o qual o incentivo recairá está, de fato, atrelado a uma vantagem ambiental, mais um passo é dado rumo à obediência ao princípio da igualdade, já que o ordenamento jurídico nacional reputa legítimo o tratamento diferenciado no caso de redução do impacto ambiental (art. 170, VI, da Lei Maior).

O próximo passo é examinar a proporcionalidade do mencionado tratamento fiscal diferenciado, haja vista que, como já dito, o ordenamento jurídico pátrio não se contenta com a constatação abstrata de que o estímulo se refere a conduta vinculada à redução do impacto ambiental, exigindo que este seja compatível com os demais princípios, bens e valores constitucionais.

Com efeito, cumpre avaliar se a discriminação veiculada pela norma tributária indutora, que proporciona incentivo fiscal, passa no teste da proporcionalidade, composto pelo exame dos seus três subprincípios: adequação, necessidade e proporcionalidade no sentido estrito.

Nesta altura, um alerta se faz indispensável, porquanto a análise dos subprincípios da adequação, necessidade e proporcionalidade em sentido estrito que se empreenderá não pretende ser conclusiva, em termos concretos, servindo apenas para indicar o raciocínio utilizado para a realização dos correlatos testes da adequação, necessidade e proporcionalidade em sentido estrito.

Isto porque um exame conclusivo de cada um deles demandaria estudos técnicos ambientais e econômicos complexos e específicos (análise do ciclo de vida do produto, verificação da elasticidade da demanda, identificação econômica do quantum ótimo a ser desonerado etc.), os quais transbordam o objeto deste trabalho.

Portanto, serão delineados os critérios que, se confirmados pelos correspondentes estudos técnicos, seriam responsáveis pela "aprovação" do incentivo fiscal ambiental nos testes da adequação, necessidade e proporcionalidade em sentido estrito.

Neste contexto, a análise ora efetivada permitirá que seja identificada a lógica das investigações a ser adotada em cada um desses exames, para que se possa concluir pela proporcionalidade ou não do incentivo fiscal ambiental correlato.

Com efeito, o subprincípio da adequação, no âmbito do incentivo fiscal, estabelece que a norma indutora que realiza determinada intervenção na ordem econômica e social deve ser idônea a alcançar um fim almejado. Trata-se, portanto, de identificar se o comando por ela preconizado é útil à realização de tal fim. 
$\mathrm{Na}$ seara específica do incentivo ambiental, o exame da adequação deve estar focado na verificação da alteração do comportamento tradicional para o comportamento ambientalmente orientado. Impende avaliar se a tributação atenuada é capaz de fazer com que agentes que desenvolvem atividades tradicionais passem a desenvolver as atividades verdes preconizadas pela norma. E mais: se aqueles que já desenvolvem tais condutas poderão vir a ampliar sua atuação, com base no estímulo fiscal correlato.

Dessa forma, cabe questionar se, por exemplo, a redução a zero da alíquota do IPI, no caso do palete de plástico, acima mencionado, seria hábil a fomentar a produção e o consumo desse produto mais sustentável.

Considerando que o tributo, no país, constitui um dos maiores custos, influenciando diretamente as decisões dos agentes econômicos, não é difícil constatar que incentivos fiscais consubstanciam medidas adequadas para que bens, serviços e modos de produção de impacto ambiental mais reduzido ganhem mais espaço.

Apesar de o incentivo fiscal constituir instrumento idôneo ao fomento de comportamentos, o seu manejo, no âmbito dos incentivos fiscais ambientais, só será considerado adequado se a conduta ambientalmente orientada tiver meios de ser fomentada (demanda elástica) e, em caso positivo, se o comportamento demandar estímulos. De tal maneira, afigura-se inadequada a alteração da tributação que alcance conduta de reduzida possibilidade de alteração ou, havendo margem para mudanças, seja dispensável, em virtude de o comportamento a ser beneficiado já contar com a plena adesão dos agentes econômicos.

Assim, por exemplo, há de se ter cautela na instituição de incentivos relacionados a bens como sal de cozinha e remédios, cujo consumo é essencial e de difícil substituição. $\mathrm{O}$ consumo destes bens é pouco sensível a mudança de preços.

Por seu turno, no caso de lâmpadas, em que há vários tipos no mercado, caso o legislador pretendesse incentivar as lâmpadas fluorescentes, dotadas de maior eficiência energética, e sendo este produto o mais barato e procurado pelos consumidores, uma intervenção estatal sobre a economia, por meio de tratamentos físcais favoráveis, seria inoportuna, visto que o próprio mercado já se move de forma adequada. Portanto, neste exemplo, também não seria atendido o requisito do "fomento de condutas", porquanto este não alteraria significativamente comportamentos. 
Note-se, entretanto, que em determinados situações será adequada a criação de incentivo fiscal ambiental, ainda que o mercado já esteja a se pautar de acordo com as opções mais sustentáveis. Isto porque há casos em que se revela necessário acelerar o curso natural do mercado, para que se consiga, por exemplo, mitigar determinado risco iminente.

Nesse sentido, a análise da adequação deve estar atenta às circunstâncias em que o estímulo será instituído, pois, quanto mais acirrado se torna o processo de crise ambiental, mais se tende a acelerar a transição para uma economia verde, com intuito de reduzir passivos ambientais e, consequentemente, mitigar os riscos a que o planeta está exposto.

À medida que os riscos ambientais relacionados a tragédias, a mudanças climáticas e à carência de recursos naturais (falta de água, alimentos, energia etc.) ganham proporção, o fomento a comportamentos de reduzido impacto ambiental, por meio de estímulos fiscais, tende a ser considerado, cada vez mais, idôneo, independentemente de se reportar a conduta que já conte com boa adesão do mercado.

A esse respeito, cumpre mencionar a lâmpada fluorescente, já citada no exemplo acima. O fomento à sua utilização pode ocorrer, via tratamento fiscal mais vantajoso, sem levar em conta se tal produto é ou não líder de mercado, caso se esteja em meio a uma crise energética.

Tal situação foi vivenciada nos idos de 2001, quando o país sofreu sucessivos apagões e precisou fazer racionamento de energia elétrica. Com efeito, o Decreto n. ${ }^{\circ}$ $3.827 / 2001^{361}$ reduziu temporariamente o IPI incidente sobre as lâmpadas compactas fluorescentes - de $15 \%$ para $0 \%$.

A redução do IPI também se estendeu a produtos e aparelhos atrelados à geração de energia elétrica, tais como turbinas, caldeiras, aquecedores, compressores, geradores elétricos e sistemas para geração de energia por meio da luz solar. Portanto, em situações de urgência, torna-se adequada a concessão de incentivos fiscais ambientais a setores afetados pela crise.

Atualmente, e em circunstâncias de "normalidade", tanto no Brasil quanto nos demais países do Ocidente, considera-se adequada a criação de incentivos fiscais ecológicos, quando os produtos, serviços e meios de produção mais sustentáveis são: i)

\footnotetext{
${ }^{361}$ Decreto n. ${ }^{\circ} 3.827 / 2002:$ "Art. 1. ${ }^{\circ}$ Fica reduzida a zero, até 31 de dezembro de 2002, a alíquota do Imposto sobre Produtos Industrializados - IPI, incidente sobre os produtos do código 8502.31.00, 8541.40.16 e 8541.40 .32 da Tabela de Incidência do Imposto sobre Produtos Industrializados - TIPI, aprovada pelo Decreto n. ${ }^{\circ} 3.777$, de 23 de março de 2001."
} 
considerados pelo mercado como "alternativos" aos tradicionais (não é a primeira opção mais conhecida/procurada), ii) elásticos e iii) desprovidos de vantagem competitiva.

Nessas condições, tais “substitutos”, que não são os mais atrativos para consumo e investimento em termos econômicos, poderiam ter sua produção e consumo efetivamente fomentados se alcançados por tratamento tributário abrandado.

Sob tal prisma, e considerando o cenário econômico atual de elevada carga tributária, a redução dos custos tributários seria medida adequada para que comportamentos ambientalmente orientados e atividades econômicas mais verdes ganhassem espaço.

Portanto, observados os critérios acima alinhavados, o incentivo fiscal revela-se veículo apropriado para a migração de uma atividade tradicional para uma atividade sustentável, sendo possível se falar em aprovação no tese da "adequação".

Note-se que a adoção de determinada conduta de menor impacto ambiental pode ser decorrente de expressa determinação legal, como no caso de lei que passa a impor à indústria a utilização de técnicas mais rigorosas para tratamento de efluentes líquidos. Em tal hipótese, caso se verifique que o mencionado comando legal está onerando demasiadamente a atividade, de modo a atingir os próprios princípios da livre-iniciativa e da livre concorrência, a instituição de incentivo fiscal seria adequada, por absorver parte de tais despesas, colaborando, assim, para o cumprimento da norma ambiental em tela.

O exemplo acima evidencia situação em que os estímulos fiscais são conferidos a fim de apoiar a adaptação à norma ambiental cogente, que gera um ônus de difícil adaptação para o setor. Mas situações há em que o agente econômico, por liberalidade, pretende investir em projetos para a redução dos impactos ambientais, porém se acautela, quanto a estes investimentos, de modo a não prejudicar a competitividade da sua atividade, quando comparada a atividades que não realizam investimentos de tal natureza ${ }^{362}$.

\footnotetext{
362 Samyra Crespo pontua que os investimentos em eficiência energética, hidríca, dentre outras, trazem resultados financeiros positivos e, portanto, já vem fazendo parte dos processos industriais, principalmente dos setores mais desenvolvidos. Entretanto, pondera que "No Brasil, por exemplo, sabe-se que a maior parte do parque das médias e pequenas empresas pouco pratica a ecoeficiência. Em parte, por desconhecimento, em parte, por incapacidade de investimento e, em parte, por não dominar novas tecnologias. A revolução da ecoeficiência não é ainda completa, mas, como bem coloca Stuart Hart em seu famoso livro sobre desafios atuais do capitalismo, a modernização ecológica da produção é inexorável. A questão que sempre fica é: como ganhar celeridade, como evitar o desastre da deterioração e do acúmulo de gases de efeito estufa na atmosfera do planeta. Poderíamos afirmar que a mobilização das empresas, em nível global, para um movimento de descarbonização da economia (diminuição de emissões de GEE gases de efeito estufa) é a evolução natural de uma agenda que procura a eficiência aliada à melhora da
} 
No contexto econômico atual, os agentes são premidos a reduzir os custos, para garantir a sua sobrevivência num mercado globalizado extremamente competitivo. Assim, é incontestável que a concessão de estímulos fiscais seria medida adequada para estimular atividades que juridicamente poderiam ser executadas de forma mais agressiva ao meio ambiente, mas que, na prática, venham a ser conduzidas de maneira sustentável.

Também se revela adequado o incentivo que visa a conferir efetividade às normas ambientais que obrigam certas atividades a investirem medidas redutoras do impacto ambiental.

Advirta-se que, ainda que determinados ganhos de imagem e de eficiência energética sejam auferidos quando a atividade passa a descartar de forma adequada seus resíduos sólidos ou a adotar, por exemplo, matérias-primas renováveis e processos e equipamentos mais ecoeficientes, o fato é que os incentivos fiscais ambientais figurariam como medida idônea para que, nessa equação, a opção pelo investimento em sustentabilidade ocorresse na velocidade e na intensidade que o atual estágio de degradação ambiental impõe e que a própria legislação ambiental preconiza.

Em tal cenário, as vantagens fiscais seriam hábeis a fomentar a migração de mais agentes para a economia verde, num movimento em que seriam reduzidos os impactos ambientais decorrentes de atividades econômicas e elevados os benefícios em prol da coletividade.

Nesta altura, uma síntese mais completa é elaborada acerca da adequação do incentivo fiscal ambiental. Assim, deve-se levar em conta, dentre outros aspectos, se a conduta ambientalmente orientada que se pretende estimular: i) refere-se a demanda elástica, ainda não incorporada pela maioria; ii) decorre de imposição legal ambiental, que gera custos àqueles alcançados por tal norma ou é fruto de opção voluntária do agente de investir seus recursos na redução dos impactos ambientais; ou, excepcionalmente, iv) já conta com a adesão da maioria, mas, em face de uma crise ambiental iminente,presta-se a acelerar, ainda mais, o curso do mercado.

Por fim, cumpre registrar que o incentivo fiscal ecológico também é hábil a estimular condutas não relacionadas diretamente à atividade econômica, tal como no caso

performance ambiental" (CRESPO, Samyra. Enfrentando o desafio da produção e do consumo sustentáveis. ALMEIDA, Fernando (Org.). Desenvolvimento sustentável 2012 - 2050: visão, rumos e contradição. Rio de Janeiro: Elsevier, 2012. p. 84). 
de manutenção da cobertura vegetal de determinado imóvel residencial ou comercial e de implantação de calçada ecológica para ampliação da área permeável.

Em tais circunstâncias a aferição da adequação é mais simples, haja vista que o ganho ambiental é inequívoco e que o comportamento tradicional ainda é o de somente se preocupar em preservar árvores e fazer melhoramentos em calçadas, quando exigidos por lei. Tal comportamento é, contudo, passível de mudanças ("elástico").

Nesse sentido, um incentivo fiscal poderá induzir pessoas físicas ou jurídicas a assumir o ônus de manter a cobertura verde de área de sua propriedade e de executar obras que aumentem a permeabilidade do entorno do imóvel, por exemplo.

Em suma, afigura-se adequado o incentivo fiscal ecológico responsável por fomentar conduta sustentável, imposta por lei ou voluntária, que é alternativa à tradicional e que traz gravame adicional ao contribuinte. Pode fomentar, ainda, conduta consagrada, que não requer estímulos, desde que uma situação de crise exija a redução imediata de passivo ambiental para a mitigação do correlato risco.

Por seu turno, por meio do teste da necessidade, será verificado se o estímulo a condutas ambientalmente orientadas, realizado por meio de incentivo fiscal ambiental, poderia ser efetivado por outro instrumento, igualmente adequado a alcançar tal fim, porém menos restritivo em relação aos demais princípios constitucionais.

Noutros dizeres, a análise do subprincípio da necessidade impõe que se verifique a existência, na situação concreta, de outro instrumento que também alcance o resultado esperado, de forma menos onerosa.

A análise em tela deverá ser realizada pela comparação entre tal instrumento e outro mecanismo, exame esse que irá variar de acordo com a conduta que se pretende estimular e com as circunstâncias específicas.

Dessa maneira, verifica-se que, se a intenção do Poder Público consiste em diminuir a produção de resíduos sólidos, inibindo o uso de embalagens descartáveis, é possível que se opte por majorar os tributos que recaem sobre tal item. Contudo, a referida medida poderia ser considerada mais restritiva do que a desoneração de embalagens duráveis e retornáveis, porquanto iria implicar uma oneração da aludida atividade, decorrente do aumento da carga tributária, já considerada sufocante no país. 
Por seu turno, havendo a opção pelo mecanismo de depósito/retorno, estruturado, por exemplo, de forma a ser cobrado depósito do produtor de garrafas e embalagens plásticas no valor de $5 \%$ do montante do produto vendido na embalagem, o qual seria devolvido ao consumidor que retornasse tais bens, possivelmente seriam identificados aspectos mais restritivos do que os observados em relação ao incentivo físcal correspondente.

Isto porque essa devolução, em determinadas circunstâncias, em que os gastos com triagem e transporte das referidas embalagens superam o montante fixado para reembolso, acaba por gerar verdadeiro ônus ao invés de bônus. Sobre a inviabilidade econômica do citado mecanismo, gerada pelas diferenças identificadas entre as regiões do Brasil, assim pontuam Ronaldo Seroa da Motta e Daiane Ely Sayago ${ }^{363}$ :

Esta compulsoriedade em todo o território nacional forçaria um nível de reaproveitamento em regiões onde o custo de triagem e transporte da sucata pode indicar um benefício social líquido negativo a este preço legal. Certamente existiriam iniciativas de subfaturamento quando os custos de triagem e estocagem determinassem. Igualmente danoso seria que o reaproveitamento incorresse em custos sociais maiores que seus benefícios.

Uma alternativa seria criar critérios de obrigatoriedade por região que levassem em conta esta viabilidade social, em que pese a complexidade de definir e calibrar estes critérios, para que sejam realmente eficazes em evitar tais situações.

Nota-se, assim, que tal mecanismo de depósito-retorno, em algumas situações, não passa no teste da necessidade, pois poderá ser responsável por restringir demasiadamente o direito de propriedade e os princípios da igualdade, livre-iniciativa e livre concorrência daqueles que não conseguirem fazer jus ao benefício da devolução, devido aos altos gastos gerados nessa tentativa de reaproveitamento da sucata.

Nesta perspectiva, e tendo em vista a dificuldade acima apontada em identificar o valor adequado para o retorno do valor depositado, de acordo com as peculiaridades de cada região do país, o incentivo fiscal poderia ser considerado o meio menos restritivo e, portanto, o instrumento necessário para que se promova um estímulo eficiente à atividade de reciclagem.

\footnotetext{
${ }^{363}$ MOTTA, Ronaldo Seroa da; SAYAGO, Daiane Ely. Propostas de instrumentos econômicos ambientais para a redução do lixo urbano e o reaproveitamento de sucatas no Brasil. Rio de Janeiro: IPEA, 1998. p. 36. Disponível: <http://www.ipea.gov.br/pub/td/td0608.pdf,looo>. Acesso em: 7 nov. 2011.
} 
Destarte, nas situações concretas em que estudos técnicos demonstrarem que os incentivos físcais ambientais são os veículos de intervenção sobre a economia que menor prejuízo causam à igualdade, à livre-iniciativa, à livre concorrência, dentre outros princípios, bens e valores, restará evidente que estes estarão aprovados no teste da "necessidade".

Nesse sentido, a opção será por incentivo fiscal ambiental que fomente a defesa do meio ambiente, sem restringir desnecessariamente outros princípios, dentre eles o da igualdade.

Por fim, quanto à proporcionalidade em sentido estrito, esta implica a ponderação acerca das vantagens e desvantagens de se instituir incentivo fiscal ambiental idôneo e necessário a atingir um fim público, mas que traz consigo alguns efeitos negativos.

De fato, além de configurar exceção à universalidade e generalidade da tributação, e acarretar reflexos no que se refere à livre concorrência, os incentivos fiscais possuem como efeito negativo, dentre outros, tornar mais complexa a legislação tributária e interferir na regular arrecadação pública ${ }^{364}$.

Nesta senda, não passará no teste da proporcionalidade em sentido estrito o estímulo fiscal ambiental que fomentar comportamentos mais sustentáveis, mas restringir injustificadamente outros princípios, bens e interesses constitucionais.

Assim é que a proporcionalidade irá impor que o ganho ambiental gerado pelo incentivo fiscal traga vantagens superiores às restrições dele decorrentes. Desse modo, o sopesamento entre o fomento à defesa do meio ambiente e as limitações a princípios constitucionais deverá concluir pelo maior peso do primeiro, no caso concreto.

Para tanto, há de se ponderar se o custo para o Estado e para a sociedade de haver um tratamento abrandado para certas situações é suplantado pelos benefícios, de ordem ambiental, auferidos por esses mesmos atores. Tal ponderação, com base nas circunstâncias e no montante da redução tributária empreendida, irá identificar se o incentivo se afigura compatível com os demais princípios restringidos no caso concreto (igualdade, capacidade contributiva, livre concorrência, livre-iniciativa, uniformidade e equilíbrio da tributação, liberdade, propriedade) ou se alberga comando que limita de forma desproporcional os aludidos princípios.

\footnotetext{
${ }^{364}$ A desoneração de determinado grupo de contribuintes implica, em tese, o aumento da carga tributária daqueles que não são afetados pelo estímulo fiscal, para que se mantenha o equilíbrio orçamentário.
} 
Essa disputa entre as vantagens e as desvantagens da concessão de incentivo fiscal ambiental pode ter sua solução facilitada quando também se encontra agregado ao objetivo de defesa do meio ambiente um objetivo extrafiscal social, auferindo-se, assim, um duplo ganho.

De fato, a conjunção de fins extrafiscais potencializa as vantagens do incentivo fiscal ambiental, o que contribui para uma aprovação menos tormentosa no teste da proporcionalidade em sentido estrito, já que as vantagens, neste caso, adquirem, naturalmente, maior relevância (peso), enquanto as desvantagens permanecem com o mesmo status.

Nesta toada, cumpre destacar que a análise quantitativa do incentivo ecológico também irá adquirir maior elasticidade quando este é voltado, a um só tempo, à defesa do meio ambiente e ao fomento de atividades que promovem a inclusão social. De fato, a união de dois ou mais fins extrafíscais de relevo conferirá maior tolerância à desoneração.

Assim, a título ilustrativo, verifica-se que a concessão de crédito presumido de IPI na aquisição de materiais reciclados de pessoas físicas poderá alcançar patamares maiores do que aqueles conferidos aos materiais reciclados em geral, por força do ganho ambiental e da inclusão social promovida na aquisição realizada diretamente de indivíduos que fazem a coleta dos materiais.

Ou seja, há fundamento jurídico para a concessão de crédito presumido em relação a materiais reciclados, sendo certo que a vinculação de tal incentivo ao fomento de atividades desenvolvidas por indivíduos irá contribuir para a obtenção de ganho social, potencializando, assim, os efeitos positivos do estímulo fiscal ambiental.

Da mesma sorte, um incentivo fiscal que visa a fomentar a efetivação de projetos voltados à redução do consumo de energia, água etc. pode prever a diminuição da carga tributária incidente sobre a aquisição de equipamentos ecoeficientes incluídos em tais projetos, de acordo com o destino desses bens. Assim, é possível haver isenção no caso de aquisição de bens por pequenas empresas, e a redução parcial da tributação no caso de aquisição por empresas de grande porte.

Resta induvidoso, pois, que a inclusão, em incentivo fiscal ambiental de um componente social irá corporificar, de forma plena, a ideia de desenvolvimento sustentável, porquanto as respectivas atividades fomentadas produzirão, simultaneamente, efeitos 
positivos de caráter ecológico, social e econômico, o que, no contexto atual, é o desafio que se impõe a todos os países.

Não é só quando há o entrelaçamento do incentivo fiscal ambiental com fins extrafiscais de viés social que as vantagens da instituição deste instrumento são realçadas; o Brasil, por suas próprias características (extensão e riqueza de ativos ambientais), detém potencial para ser líder mundial na produção de bens e serviços sustentáveis, circunstância que torna os estímulos fiscais ambientais estratégicos, em termos econômicos.

De tal maneira, a ponderação, em sede de proporcionalidade em sentido estrito, acerca das vantagens e desvantagens da instituição do incentivo fiscal ambiental não pode descurar dos aspectos acima destacados, os quais revelam os efeitos positivos do multicitado instrumento.

Considerando-se a realidade brasileira de graves diferenças sociais e de grandes estoques ambientais ainda existentes, mas sob ameaça de degradação ou de exploração inadequada, as vantagens em se instituir os estímulos em pauta adquirem força e visibilidade indisfarçáveis, sendo necessário ponderar concretamente a justa medida de tais incentivos.

Nesta perspectiva, será proporcional o estímulo que contenha estímulo fiscal na justa medida que irá conduzir os agentes a se pautarem de forma sustentável (vantagem financeira atrativa), de sorte a não restringir demasiadamente outros princípios atingidos com o tratamento fiscal abrandado concedido, a exemplo da livre concorrência ${ }^{365}$.

Nessa linha, impende frisar que o incentivo fiscal ecológico, por consubstanciar intervenção estatal sobre o domínio econômico, deve apenas induzir comportamentos, o que ocorre de forma gradual. De modo que, se o objetivo for vedar determinada atividade, a opção deve ser por uma expressa proibição legal, realizada mediante a intervenção direta do ente estatal.

Assim sendo, caso o estímulo seja concedido em montante injustificado, inibindo a sobrevivência de atividades não incentivadas, as desvantagens tenderão a superar as vantagens, não havendo que se falar em atendimento ao princípio da proporcionalidade em sentido estrito.

\footnotetext{
${ }^{365}$ A questão da justa medida do incentivo será retomada de forma mais aprofundada no item seguinte, em que serão examinados os incentivos ecológicos e a livre concorrência.
} 
Ainda quanto ao aspecto gradual da norma incentivadora ambiental, cumpre registrar que deve ser estipulado um período de duração ajustado aos objetivos pretendidos pela norma. Descabe, pois, a continuidade do incentivo, nas mesmas condições, quando a conduta já começa a ser absorvida pelo mercado e quando as metas de proteção ambiental já estiverem sendo cumpridas.

Assim, o estímulo para continuar a fomentar, ao longo do tempo, condutas que efetivamente trazem um ganho ambiental deverá ser concedido por tempo certo e, de preferência, de forma escalonada. Nessa esteira, será reduzida a intensidade do estímulo, na medida do alcance dos resultados desejados pelo incentivo fiscal.

Todavia, é possível a manutenção do estímulo por mais tempo, desde que se estabeleçam metas mais arrojadas a ser perseguidas em etapas bem definidas.

Com efeito, será proporcional o incentivo fiscal forjado de maneira que, durante todo o período em que estiver em vigor, afigure-se apto a induzir condutas ambientalmente orientadas, cujos resultados concretos são tidos como superiores às restrições a princípios constitucionais dele decorrentes, portanto, com vantagens ambientais que ultrapassam as desvantagens produzidas.

Nota-se, assim, que à luz do ordenamento jurídico nacional, não se afigura tarefa simples avaliar a compatibilidade de incentivo fiscal ambiental com os demais princípios, bens e valores juridicamente tutelados. Buscou-se, até aqui, trazer diretrizes balizadoras do raciocínio a ser aplicado, as quais seguem abaixo resumidas:

a) A primeira medida é averiguar se a conduta incentivada contempla estímulo que resultará num ganho ambiental.

b) Feita tal constatação, deve ser realizado o teste da adequação, em que é avaliado se seria apropriada a criação de incentivo fiscal para fomentar a referida conduta, ou se este comportamento já se encontra consagrado ordinariamente, quedando-se inidôneo o estímulo pretendido.

c) Indispensável, ainda, investigar a necessidade de a indução ser veiculada por meio de incentivo fiscal, questionando-se se este consubstancia o instrumento que alcançará o fim desejado pela norma, da forma menos onerosa possível. Para tanto, este instrumento econômico deve ser comparado com outros, a exemplo da elevação de tributos, do mecanismo de depósito/retorno etc. A conclusão concreta de que o incentivo 
fiscal ambiental constitui instrumento econômico menos restritivo aos demais princípios constitucionais permitirá a aprovação no teste da necessidade.

d) A proporcionalidade em sentido estrito demandará uma ponderação entre as vantagens ambientais auferidas e as desvantagens experimentadas em relação aos demais princípios, bens e valores colidentes, no caso concreto. Essa ponderação deverá concluir que o incentivo fiscal ambiental alberga solução que concretiza, na maior medida possível, o objetivo de defesa do meio ambiente e demais fins e princípios colidentes, na espécie. São consideradas, nesse sopesamento, a justa medida do estímulo durante todo o período em que é instituído, a sua eficiência e a intensidade das desvantagens experimentadas com a instituição do incentivo fiscal. Se a intensidade da intervenção realizada nos demais princípios for compatível com o fim a que se propõe, reputa-se proporcional o incentivo fiscal ambiental.

e) O fato de ser agregado, ao fim extrafisscal de proteção ambiental, um outro fim extrafiscal de viés social permitirá que se verifique um duplo ganho, ampliando, assim, os efeitos positivos do incentivo. As vantagens do incentivo tendem, neste caso, a superar as desvantagens da desoneração, bem como é aumentada a tolerância, em termos quantitativos, do incentivo ambiental.

f) As peculiaridades do Brasil, em termos de riqueza de ativos ambientais e de extensão territorial, permitem que o país lidere o ramo de bens e serviços sustentáveis, pelo que o estímulo a atividades de tal natureza pode ser estratégico, proporcionando ganhos de grande porte para a economia nacional.

g) Considerando que a análise da proporcionalidade é lastreada no exame concreto da situação fática e jurídica subjacente, a constatação de que o incentivo fiscal atende a tal primado não se mantém, no caso de haver alterações no aludido cenário, pelo que deve ser criada previsão de reavaliação periódica ou firmado um prazo razoável de duração. Um mecanismo para manter esse ajuste seria a concessão escalonada do estímulo.

Nesta altura, cumpre reproduzir ementa relativa a precedente em que o Supremo Tribunal Federal, em sede do Recurso Extraordinário n. ${ }^{\circ}$ 239.397/ $\mathrm{MG}^{366}$, afastou a alegação de violação à igualdade em relação a incentivo fiscal que reduzia à metade o

\footnotetext{
${ }^{366}$ STF, Recurso Extraordinário n. ${ }^{\circ}$ 239.397/MG, Rel. Min. Ilmar Galvão, Primeira Turma, j. 21.03.2000. Disponível em: $<$ http://www.stf.jus.br/portal/jurisprudencia/listarJurisprudencia.asp?s1=\%28RE\%24\%2ESCLA \%2E+E+23 9397\%2ENUME\%2E\%29+OU+\%28RE\%2EACMS\%2E+ADJ2+239397\%2EACMS\%2E\%29\&base=base Acordaos>. Acesso em: 15 fev. 2012.
} 
valor da taxa florestal instituída pelo Estado de Minas Gerais, no caso de a empresa siderúrgica demonstrar o reflorestamento na mesma proporção que consumiu de carvão.

EMENTA: TRIBUTÁRIO. ESTADO DE MINAS GERAIS. TAXA FLORESTAL. LEI N. ${ }^{\circ} 7.163 / 1977$. ALEGADA OFENSA AOS ARTS. 5. ${ }^{\circ}$, CAPUT; 145 , II E $\S 2 .^{\circ}$; 150, I E IV; E 152, TODOS DA CONSTITUIÇÃO FEDERAL. Exação fiscal que serve de contrapartida ao exercício do poder de polícia, cujos elementos básicos se encontram definidos em lei, possuindo base de cálculo distinta da de outros impostos, qual seja, o custo estimado do serviço de fiscalização. Efeito confiscatório insuscetível de ser apreciado pelo STF, em recurso extraordinário, em face da necessidade de reexame de prova. Súmula 279 do STF. Descabimento da alegação de ofensa ao princípio da isonomia, por razões óbvias, diante do incentivo fiscal, em forma de redução do tributo, previsto para as indústrias que comprovarem a realização de reflorestamento proporcional ao seu consumo de carvão vegetal. Recurso não conhecido.

Deveras, no bojo do Voto do Relator, foi reconhecido que o incentivo fiscal concedido às empresas siderúrgicas que comprovassem o reflorestamento na mesma proporção de seu consumo de carvão (Lei n. ${ }^{\circ}$ 7.163/1977, art. 207, $\S 3 .^{\circ}$ ) seria, inclusive, um dos incentivos fiscais mais razoáveis, restando, pois, atendido o princípio da isonomia.

Noutro giro, consigne-se que, na linha das considerações até aqui urdidas quanto à investigação concreta da compatibilidade do incentivo fiscal ambiental com o ordenamento jurídico, encontram-se as novas diretrizes cunhadas pela União Europeia no ano de 2008.

As ponderações nelas contidas buscam elucidar o controle das ajudas estatais, no âmbito ambiental, para que se assegure que as medidas de ajuda resultarão em níveis superiores de proteção ambiental. Desse modo, os seus efeitos positivos deverão ir além dos efeitos negativos, especialmente no que tange à distorção concorrencial.

Nesta senda, trouxeram contribuições à matéria, especialmente no tocante à identificação de uma justificação econômica mais sólida e à utilização de procedimentos mais eficazes na realização deste sopesamento.

Um dos pontos de maior relevo foi a fixação de que a análise das ajudas estatais deveria estar lastreada em uma "prova de sopesamento", por meio da qual seria ponderada a incidência positiva da medida da ajuda e seus potenciais efeitos secundários negativos. 
José María Combos Gomez ${ }^{367}$, depois de avaliar o conteúdo das diretrizes criadas em 2008, sustenta que as ajudas estatais destinadas à preservação do meio ambiente são consideradas compatíveis com o mercado comum desde que, com base na "prova de sopesamento", seja identificado o incremento das atividades de proteção ambiental sem que se afete de forma adversa a concorrência.

Com efeito, o aludido autor sintetizou os requisitos que as ajudas estatais, em favor do meio ambiente, deveriam reunir, nos termos abaixo transcritos ${ }^{368}$ :

a) Devem ser necessárias e produzir efeito incentivador: é dizer, a ajuda deve ser destinada àquele beneficiário que irá mudar o seu comportamento, de modo que o nível de proteção ambiental seja superior à situação anterior, em que não havia ajuda. Os referidos incentivos devem estar voltados ao alcance de uma proteção superior àquela que já se encontrava estipulada pelas normas comunitárias ou a atingir proteção posta por regra nacional mais exigente que a comunitária.

b) Devem ser proporcionais, no sentido de que não se poderia ter alcançado o mesmo resultado se a ajuda fosse concedida em montante inferior. Neste contexto, o montante da ajuda deve limitar-se ao mínimo necessário para alcançar a proteção desejada do meio ambiente.

c) Os efeitos negativos das ajudas devem ser limitados de maneira que o balanço global seja positivo, para o que é fundamental que as ajudas estejam bem especificadas.

José María Combos Gomez ${ }^{369}$ salienta ainda que, em relação às reduções e isenções de tributos ambientais, estas poderão ter palco nas situações em que estejam ajustadas ao mercado comum, ou seja, sempre que propiciem uma melhora significativa para o meio ambiente, sem prejudicar o objetivo geral perseguido. Assim, uma vez atendidos tais requisitos, as diretrizes reconhecem a compatibilidade das correlatas isenções e reduções fiscais, tendo sido fixada uma duração máxima de 10 anos.

Além disso, devem ser cumpridas as seguintes condições: a empresa beneficiária deve pagar um percentual significativo do tributo e a redução ou isenção fica condicionada a acordos ambientais entre os Estados e as empresas beneficiárias. Por tais acordos, estas

\footnotetext{
${ }^{367}$ COBOS GOMES, José María. Traytoria y principios de la tributación ambiental en la Unión Europeia. In: BECKER, Fernando; CAZORLA, Lui Maria; MARTÍNEZ-SIMANCAS, Julián (Dir.). Tratado de tributación medioambiental. Pamplona: Aranzandi, 2008. v. 2, p. 875-876.

${ }^{368}$ Id. Ibid., p. 876.

${ }^{369}$ Id. Ibid., p. 878.
} 
se comprometem a alcançar objetivos de proteção ambiental durante o período de vigência do tratamento tributário diferenciado. Os acordos estão sujeitos à avaliação pela Comissão, e seu controle será efetivado pelos Estados-membros e revisados no mínimo a cada três anos, à luz das evoluções tecnológicas e demais avanços ${ }^{370}$.

Note-se que os parâmetros aplicáveis à União Europeia, acima descritos, possuem, em linhas gerais, os mesmos objetivos daqueles desenvolvidos no presente item. Os referidos critérios buscam, na sua essência, identificar a proporcionalidade na decisão que reputa isonômico o incentivo fiscal ambiental.

Já há, de fato, um consenso acerca da necessidade de o incentivo fiscal: i) afigurarse idôneo a fomentar o comportamento ambientalmente orientado; ii) produzir ganhos ambientais cujos efeitos positivos superem os negativos; iii) ser instituído em montante ajustado ao fim perseguido; iv) submeter-se a avaliação para identificação de distorções; v) ter duração limitada.

\subsubsection{Capacidade contributiva e incentivos fiscais ambientais}

No que se refere à aplicação da capacidade contributiva no âmbito dos incentivos fiscais ambientais, verifica-se que, da mesma forma que ocorre no caso dos incentivos fiscais em geral, será observado o princípio da capacidade contributiva no seu aspecto objetivo, porquanto ocorrerá no campo da tributação, que o pressupõe. Todavia, nem sempre será possível que a graduação da desoneração adote como diretriz o referido cânone no seu viés subjetivo.

Sob tal prisma, uma isenção relacionada a um produto ecoeficiente poderá alcançar empresas dotadas de elevada capacidade econômica, ensejando que estas recolham menos tributo ao erário do que outras com menos capacidade, haja vista que o objetivo de tal imposição não é potencializar a arrecadação e exigir mais de quem detém maior capacidade econômica, senão fomentar a industrialização de bens de baixo impacto ambiental.

Logo, o ente tributante, que visa a fomentar investimentos em equipamentos dotados de maior eficiência energética, poderá desonerar o consumo de tais bens,

\footnotetext{
${ }^{370}$ COBOS GOMES, José María. Op. cit., p. 879.
} 
independentemente da análise da capacidade contributiva daquele que os produz ou os adquire.

Firmadas tais balizas quanto aos princípios da legalidade, capacidade contributiva e princípio da igualdade conjugado com o princípio da proporcionalidade, cabe destacar em que medida um incentivo fiscal ambiental que respeita os primados em pauta pode ser considerado inconstitucional por violar a livre concorrência. É do que se passa a tratar.

\subsubsection{A questão concorrencial e a concessão de estímulos fiscais ambientais}

No âmbito tributário, o princípio da livre concorrência estabelece que o tributo não pode ser responsável por distorções concorrenciais. Resta claro que o incentivo físcal voltado à defesa do meio ambiente, para ter compatibilidade com o mencionado vetor constitucional, deve albergar estímulo cuja intensidade seja suficiente para fomentar a atividade verde tutelada, sem, entretanto, amesquinhar a atividade não contemplada pela norma.

O debate acerca dos critérios para a compatibilização dos incentivos fiscais ambientais com a livre concorrência é bastante desenvolvido na Europa, região do mundo que, ao longo dos anos, mais tem revelado preocupação com a problemática ambiental e que detém, ao mesmo tempo, notável compromisso com a igualdade de condições no seu mercado comunitário.

Portanto, ao lado do acentuado interesse pela proteção do meio ambiente, os países componentes da União Europeia buscam adotar uma política de concorrência ajustada a um mercado interno comunitário (arts. 87 a 89 do Tratado da antiga Comunidade Europeia), razão por que as normas instituidoras de incentivos fiscais são elaboradas de forma bastante ponderada, no intuito de evitar distorções nesse mercado comum.

A esse respeito, assevera Fernando Serrano Antón que a proteção do meio ambiente é considerada como uma prioridade na Europa, de sorte que as isenções tributárias ou as subvenções, ainda que possam vir a criar problemas econômicos e beneficiar quem contamina, podem ser manejadas desde que observados os requisitos do mercado único e as regras concorrenciais. Em tese, os Estados-membros da União Europeia possuem liberdade dentro dos aludidos limites a fim de utilizar as receitas dos tributos ambientais 
para financiar investimentos de cunho ambiental ou financiar o recolhimento de resíduos tóxicos $^{371}$.

Por seu turno, ressalta Cláudia Dias Soares que o legislador comunitário, tendo em vista a necessidade de compatibilizar o mercado comum com outros objetivos, tem admitido a concessão de auxílios estatais, dentre eles incentivos fiscais ambientais. Para tanto, examina-se a compatibilidade dos apoios com a ordem jurídica comunitária, mediante a ponderação dos efeitos adversos na concorrência e dos efeitos benéficos ao ambiente que resulta de sua concessão ${ }^{372}$.

Casalta Nabais ${ }^{373}$ observa que, nos últimos tempos, há um movimento no sentido de se tentar ajustar a política da concorrência com a política ambiental, voltada para a defesa do equilíbrio ecológico e para o desenvolvimento sustentável. Desse modo, os incentivos fiscais ecológicos, especialmente quando vinculados a impostos ambientais, estão a adquirir mais receptividade no direito comunitário.

Já Cristóbal J. Borrero Moro ${ }^{374}$ chama a atenção para o fato de que a instituição de tributos ambientais nos diversos países da Europa abre a possibilidade de perda da competitividade da indústria nacional, defendendo, sob tal premissa, que os incentivos fiscais ambientais seriam uma das medidas que poderiam ser manejadas com o objetivo de atenuar tais efeitos.

Assim sendo, a instituição de determinado incentivo fiscal ambiental (vinculado a tributo ambiental ou não) irá exigir que se avalie, concretamente, se este, muito embora seja compatível com os princípios do poluidor-pagador, da prevenção e da precaução e do protetor-recebedor, bem como esteja em consonância com o princípio da igualdade, legalidade etc., se revela inconstitucional por causar prejuízos demasiados à livre concorrência.

Nesta linha, ressalta Fernando Serrano Antón ${ }^{375}$ que as restrições à concessão de benefícios fiscais na União Europeia fundamentam-se em dois aspectos: no desconforto de se beneficiar agente que polui e na possibilidade de surgirem distorções na concorrência geradas em decorrência de ajudas estatais.

\footnotetext{
${ }^{371}$ SERRANO ANTÓN, Fernando. Op. cit., v. 2, p. 838.

372 SOARES, Cláudia Dias. Op. cit., p. 21.

${ }^{373}$ NABAIS, José Casalta. Tributos com fins ambientais. Revista Tributária e de Finanças Públicas, São Paulo, ano 16, v. 80, p. 253, maio-jun. 2008.

${ }^{374}$ BORRERO MORO, Cristóbal José. Op. cit., p. 20.

${ }^{375}$ SERRANO ANTÓN, Fernando. Op. cit., v. 2, p. 832-833.
} 
Entretanto, em determinadas situações, os aludidos obstáculos são ultrapassados, sendo reconhecidas ajudas estatais em favor do ambiente, cujos principais exemplos, extraídos das lições do aludido autor, são: as ajudas de funcionamento em favor da gestão de resíduos e do desenvolvimento energético; as ajudas das atividades de assistência e assessoramento das pequenas e médias empresas em matéria de meio ambiente; e as ajudas de investimento.

No que tange às ajudas concernentes à gestão de resíduos e desenvolvimento energético, tem-se que, inicialmente, as empresas devem arcar com os custos para o tratamento dos resíduos industriais, em atendimento ao princípio do poluidor-pagador. Entretanto, se o contribuinte está diante de norma nacional mais restritiva do que a norma comunitária, que lhe trará perda de competitividade, seria justificável a ajuda estatal ${ }^{376}$.

Nesses casos, a citada ajuda de funcionamento duraria por um prazo máximo de 5 anos (auxílio decrescente). Assim, o primeiro ano poderia ter uma desoneração de $100 \%$ dos custos adicionais do primeiro ano, reduzindo-se de maneira gradual até alcançar o zero $^{377}$.

Quanto ao desenvolvimento energético, verifica-se que a permissão de concessão de ajudas de funcionamento dependeria do custo de mercado de eletricidade e de calor, somente sendo cabível o apoio quando tal custo de mercado for inferior ao custos que se pretende estimular $^{378}$.

No que tange às ajudas às pequenas e médias empresas em matéria ambiental, constata-se que esta, embora sujeita ao atendimento de diversos requisitos, contaria com maior tolerância em relação às grandes empresas ${ }^{379}$.

No que diz respeito às ajudas ao investimento, estas estão atreladas aos investimentos necessários ao cumprimento de objetivos ambientais, a exemplo dos investimentos em instalações e equipamentos, cujo fim seja reduzir ou eliminar a contaminação e outros efeitos nocivos, bem como promover adaptações no modo de produção para proteger o meio ambiente.

Também se encontram inseridos nessa categoria os gastos com a transferência de tecnologias, tais como a aquisição de licença de exploração ou de conhecimentos técnicos

\footnotetext{
${ }^{376}$ SERRANO ANTÓN, Fernando. Op. cit., v. 2, p. 832-833.

${ }^{377}$ Id., loc. cit.

${ }^{378}$ Id., loc. cit.

${ }^{379}$ Id., loc. cit.
} 
patenteados. De tal sorte, os valores correspondentes ao incentivo limitam-se estritamente aos custos dos investimentos adicionais realizados para alcançar os objetivos de proteção ambiental $^{380}$.

Da sua parte, Cristóbal J. Borrero Moro ${ }^{381}$, buscando sintetizar critérios por intermédio dos quais a concessão de isenções, no âmbito de impostos ambientais, estaria compatível com o ordenamento comunitário, firmou que tais isenções: i) deveriam ser concedidas por prazo certo, ii) não poderiam ser responsáveis por proporcionar lucratividade ao contribuinte e iii) sofreriam reduções graduais ao longo do tempo.

Diante de tal cenário, propõe a instituição de isenções em relação a tributos que gravam as receitas daquelas empresas que assumem a responsabilidade pela coleta e reciclagem dos seus produtos usados ${ }^{382}$.

Portanto, desde que atendidos os referidos pressupostos, os incentivos concedidos às empresas que promovem a coleta dos produtos usados pelos consumidores estariam em harmonia com o ordenamento comunitário ${ }^{383}$.

Partindo das premissas cunhadas pelo mencionado autor, pode-se concluir que haverá compatibilidade entre incentivos fiscais ambientais e o princípio da livre concorrência quando aqueles forem instituídos considerando os ônus arcados por certos particulares, seja por força da introdução de tributo ambiental que onera sua atividade, deixando-os em desvantagem competitiva em relação a outros agentes que não arcam com tal tributo, seja em vista de outras despesas assumidas para atingir objetivos ambientais que não possuem correspondência na atividade tradicional (investimentos em novas tecnologias, gastos adicionais com coleta seletiva, reciclagem, insumos verdes, processos produtivos de maior eficiência energética, altos custos pela falta de produção em escala etc.).

Nesta perspectiva, verifica-se que os incentivos fiscais ambientais, criados sob a observância dos três requisitos apontados Cristóbal Borrero Moro, não irão vulnerar o equilíbrio concorrencial, porquanto sua instituição, longe de gerar lucratividade extraordinária e competitividade desleal para os contribuintes por eles alcançados, promoverá o estímulo necessário para que as atividades ambientalmente orientadas possam

\footnotetext{
${ }^{380}$ SERRANO ANTÓN, Fernando. Op. cit., v. 2, p. 832-833.

${ }^{381}$ BORRERO MORO, Cristóbal José. Op. cit., p. 21.

${ }^{382}$ Id., loc. cit.

${ }^{383}$ Id., loc. cit.
} 
expandir-se em condições de igualdade com as atividades tradicionais que, além de já estar estabelecidas no mercado, produzindo em escala, são desenvolvidas sem os mesmos investimentos e gastos voltados à preservação do meio ambiente.

Ademais, como o fomento terá duração limitada, perdurando enquanto a atividade incentivada necessitar de estímulo para se estabelecer e evoluir no mercado, com reduções graduais, na medida do próprio desenvolvimento autônomo da atividade, o tratamento tributário diferenciado será sustado no momento em que as situações fática e jurídica subjacentes não mais o justifiquem.

Nestas condições, há o estímulo a condutas ambientalmente responsáveis, sem que se possa vincular tal indução a uma medida que distorça os pilares do livre-mercado, principalmente considerando, como já dito, o fato de que as atividades "tradicionais" já se encontram no mercado, com produção em escala, consumidores conquistados, podendo até mesmo estar usufruindo de incentivos econômicos próprios.

Com efeito, para que se tenha uma visão concreta acerca dessa questão dos custos das atividades ambientalmente orientadas em contraponto com as tradicionais, cumpre trazer contribuições extraídas do trabalho da lavra de Ronaldo Seroa da Motta e Daiane Ely Sayago ${ }^{384}$, intitulado "Propostas de instrumentos econômicos ambientais para a redução do lixo urbano e o reaproveitamento de sucatas no Brasil”".

Em tal estudo, os mencionados autores demonstram que a reciclagem constitui atividade benéfica para a coletividade, haja vista que o reaproveitamento de sucatas reintroduz na estrutura produtiva parte dos materiais já utilizados. Assim, são evitados os “custos ambientais intratemporais (poluição) da disposição do lixo, como também os custos intertemporais (esgotamento) de uso dos recursos exauríveis".

Ressaltam, todavia, que enquanto os custos evitados se convertem em benefícios para toda a sociedade, o aumento dos custos decorrentes destes benefícios, tais como despesas com a coleta, triagem, beneficiamento e transporte de sucatas, recai sobre os agentes privados e o Poder Público. Muitas vezes, os altos gastos para a substituição da matéria-prima virgem por matéria reciclada inviabilizam economicamente a troca ${ }^{385}$.

\footnotetext{
${ }^{384}$ MOTTA, Ronaldo Seroa da; SAYAGO, Daiane Ely. Op. cit., p. 6.

${ }^{385}$ Ronaldo Seroa da Motta e Daiane Ely Sayago caracterizam a composição dos custos do material virgem e do reciclado, nos seguintes termos: "O valor da matéria-prima virgem resulta do seu custo de extração, da escassez das suas reservas e de seus custos (principalmente de energia) de processamento. $\mathrm{O}$ custo do material reciclável, por outro lado, depende do seu custo de coleta, separação, beneficiamento e transporte.
} 
Aponta o aludido estudo que um dos fatores que limitam a expansão do reaproveitamento de sucatas no Brasil é a volatilidade da oferta e da demanda, causada pela reduzida escala do setor e por seus altos custos de triagem e estocagem, situação que acaba por tornar o referido setor marcado pela concentração e verticalização.

Esta concentração é favorecida, ainda, pelo fato de existirem "outras políticas setoriais de fomento aos investimentos da produção de matéria virgem subsidiada, tanto na forma estatizada como privada". Casos emblemáticos, por exemplo, são o do setor siderúrgico para o alumínio e o de celulose para o papel, além do petroquímico ${ }^{386}$.

Diante desse cenário, o citado trabalho propõe uma atuação conjunta do setor privado e do Poder Público, com o objetivo de implantar instrumentos econômicos hábeis a incentivar a dinamização do setor.

Com lastro nas constatações acima feitas, relativas à reciclagem, é possível concluir que, uma vez realizado estudo do balanço ambiental e energético do ciclo do reaproveitamento (em termos de coleta, triagem e transporte de sucatas) e identificadas as vantagens de sua utilização, é cabível a criação de instrumentos econômicos que fomentem a aludida atividade.

Tal instrumento, todavia, há de ser adequadamente mensurado. Para tanto, deve ser apurado montante que guarde equivalência com os gastos adicionais demandados por esse setor, por meio de análise técnica que considere, entre outros fatores: i) os custos com coleta, transporte, triagem e beneficiamento, ii) a reduzida escala de produção da atividade, iii) a concentração e verticalização do setor e iv) os estímulos existentes em relação aos correlatos materiais virgens.

Portanto, uma vez dimensionado adequadamente o estímulo a ser instituído, a sua aplicação concreta deverá acelerar a expansão da atividade, com o consequente aumento da

Quanto maior o custo da matéria-prima virgem em relação ao custo de substituição por sucatas, maior será o estímulo econômico para a coleta do resíduo e as possibilidades de absorver os custos de coleta e transporte, como são os casos de alumínio e aço.

Este nível depende também da forma como os resíduos são coletados e transferidos para o processador de matéria-prima. Estas formas determinam o nível de qualidade e, assim, o de aproveitamento dos resíduos. As fontes de material para o reaproveitamento são o lixo urbano coletado por serviços públicos ou catadores, as sobras do comércio e as geradas no próprio processamento de matéria-prima na indústria. Todavia, vale notar que um custo de coleta seletiva, superior ao da coleta convencional, pode se justificar socialmente pelos custos ambientais evitados com o reaproveitamento. Importante será determinar estes custos evitados para, então, definir os custos de coleta compensatórios" (MOTTA, Ronaldo Seroa da; SAYAGO, Daiane Ely. Op. cit., p. 7).

${ }^{386}$ MOTTA, Ronaldo Seroa da; SAYAGO, Daiane Ely. Op. cit., p. 7. 
escala e a diminuição da concentração do setor, o que proporcionará, ao longo do tempo, a redução dos custos adicionais da atividade e o equilíbrio no mercado.

Assim, havendo a opção pela criação de instrumento econômico tributário que albergue vantagem financeira ao setor em montante condizente com o déficit de competitividade apurado pelo citado estudo técnico, tal instrumento permitiria a participação do produto reciclado no mercado em condições de igualdade com a matériaprima virgem.

Nesta perspectiva, não há que se falar em violação ao primado da livre concorrência, mas, ao contrário, observa-se, neste exemplo, a sua concretização, uma vez estabelecida a paridade de condições entre os agentes econômicos.

Ademais, como já pontuado, a expansão da referida atividade irá possibilitar que os seus custos também sejam minimizados, permitindo, desse modo, que o estímulo seja gradualmente reduzido e, enfim, extinto.

A análise concreta de incentivo fiscal no âmbito do reaproveitamento de sucatas evidencia que os requisitos delineados por Cristóbal Borrero Moro para a criação de incentivos fiscais na Espanha (a concessão de estímulos por prazo certo, sem o fomento de lucro e com a redução gradual ao longo do tempo), são balizas válidas também aqui no Brasil, porquanto inibem a transgressão à livre concorrência.

Insta registrar, pela sua importância, que embora tal demonstração tenha sido realizada com lastro em estudo específico para a reciclagem, as premissas em foco também poderiam ser válidas se utilizada como base pesquisa contendo análise dos custos e dos entraves à expansão no mercado quando se empregam matérias-primas renováveis, bem como novos sistemas de produção, dotados de maior eficiência energética e/ou com redução de emissões de gases de efeito estufa.

Tais materiais e meios de produção mais verdes e alternativos aos tradicionais demandam, via de regra, custos adicionais e encontram certa dificuldade em competir no mesmo patamar de igualdade com os já existentes, razão pela qual as premissas postas pelo aludido autor, que envolvem a justa medida do incentivo e a sua limitação no tempo, poderão ser válidas para evitar que incentivos fiscais, que buscam estimular as mais variadas atividades ambientalmente orientadas, causem distúrbios concorrenciais. 
Em suma: constatadas as vantagens ambientais decorrentes de determinada atividade, abre-se espaço para a criação de estímulos por meio de instrumentos econômicos (dentre eles, incentivos tributários), cujo montante deverá corresponder à quantia adequada e suficiente para que se fomente tal atividade, ganhando-se escala e reduzindo-se os custos do setor. E, nessa senda, à medida que se amplia a atividade e que se ganha competitividade, diminui-se o estímulo, até que este possa ser extinto.

Logo, o incentivo fiscal ambiental não visa a beneficiar empresas ineficientes, indo de encontro à lógica do mercado, mas busca, tão somente, conferir um incentivo temporário para que os setores beneficiados consigam ter competitividade. $\mathrm{O}$ estímulo fiscal, por si só, não será responsável pela lucratividade da atividade verde, mas apenas fomentará a estruturação e a consolidação do negócio.

Esclareça-se que o objetivo é que a atividade verde seja lucrativa, contudo, a lucratividade deve decorrer de outros fatores relacionados à qualidade e eficiência da produção, serviço e bens verdes.

Assim sendo, por meio do incentivo fiscal ambiental, a atividade sustentável deve ser estimulada, superando-se déficits competitivos e obtendo-se maior atratividade, indispensáveis à fixação e à expansão da atividade no mercado.

Portanto, não há autorização para que se veicule, mediante incentivo fiscal, estímulo excessivo que torne, de maneira artificial, a atividade verde viável e as atividades tradicionais inviáveis, em face, por exemplo, de estímulos criados em montante superior ao necessário para o fomento perseguido ou mantidos por prazo além do indispensável para a obtenção do referido objetivo.

A ressalva que se faz a esse raciocínio, todavia, repousa na circunstância de alguma atividade verde viável e lucrativa precisar ser estimulada, para que sua expansão ocorra de forma ainda mais acelerada, com o fim de reduzir imediatamente determinado risco ambiental.

Em tal situação, apesar de as referidas atividades, em tese, não precisarem de estímulos, o contexto específico de crise ambiental (falta de água, enchentes, apagões etc.) irá justificar a concessão de tratamento fiscal vantajoso enquanto perdurar a crise, ainda que aquele seja responsável por, de alguma forma, causar prejuízos à livre concorrência.

Neste sentido, resta evidente que a livre concorrência afigura-se um limitador ao manejo dos instrumentos econômicos voltados ao fomento das atividades sustentáveis. 
Contudo, se esse e outros limites forem aplicados de forma rígida a ponto de não ser possível evitar as crises ambientais, estas serão responsáveis por legitimar restrições mais incisivas à livre concorrência.

Portanto, para que se evitem medidas drásticas, imperioso que se apliquem todos os instrumentos capazes de contribuir com a migração da economia tradicional para a de baixo carbono, dentre eles, os incentivos fiscais ecológicos, que não podem ter seu conteúdo amesquinhado em prol de uma proteção exacerbada conferida ao princípio da livre concorrência.

Em qualquer das situações, seja de "normalidade", seja de "crise", há de se avaliar, concretamente, a justa medida da vantagem fiscal, buscando identificar o limite em que esta poderá ser capaz de, a um só tempo, preservar na maior medida possível a igualdade de condições entre concorrentes e fomentar comportamentos, bens e serviços que contribuem para a redução do impacto ambiental.

\subsubsection{Renúncia de receita e incentivos fiscais ambientais}

O trabalho em tela defende que a aplicação do regime jurídico da Lei de Responsabilidade Fiscal deve ser a mais ampla possível, permitindo a transparência na identificação do montante destinado aos estímulos fiscais instituídos.

Nesse sentido, o fato de o incentivo fiscal ser voltado à causa ambiental não altera tal dever. Afinal de contas, trata-se de princípio de relevo, embora não detenha supremacia, de forma apriorística, em relação aos outros tantos princípios constitucionais, não sendo cabível, pois, qualquer tipo de diferenciação.

O estágio atual de desenvolvimento e de crise ambiental fez com que o Estado brasileiro adotasse comprometimento, sem precedentes, em relação às questões ambientais, com o intuito de conferir, nos mais diversos setores, a sua parcela de contribuição.

Assim como os demais incentivos fiscais, o incentivo fiscal ambiental submete-se aos requisitos estabelecidos pela Lei Complementar n. ${ }^{\circ}$ 101/2000, pelo que toda receita que for renunciada por força da sua concessão terá de ser devidamente considerada no que tange às metas fiscais estipuladas pela Lei de Diretrizes Orçamentárias. 
Portanto, não será dispensada a demonstração de que o montante total renunciado se acha previsto na estimativa da receita da lei orçamentária, bem como de que sua implementação não comprometerá as metas de resultados fiscais da Lei de Diretrizes Orçamentárias.

Nesta perspectiva, não sendo possível a aludida demonstração, imprescindível se faz a adoção de medidas compensatórias, hábeis a incrementar a arrecadação tributária (aumento de alíquota, criação de tributo ou contribuição).

Destarte, não basta que a lei veiculadora de incentivo físcal ambiental seja aprovada; imperioso que as medidas compensatórias correspondentes às respectivas perdas de arrecadação sejam efetivadas, para que tais instrumentos possam ter validade.

As referidas medidas se tornam despiciendas em se tratando de tratamento fiscal diferenciado instituído em sede dos chamados tributos regulatórios (imposto sobre produtos industrializados - IPI e operações de crédito, câmbio e seguro, ou relativas a títulos ou valores mobiliários - IOF etc.), bem como nas hipóteses de renúncia de receitas de baixo valor (cujo teto não é indicado pela norma legal).

Ilustrando a aplicação concreta dos requisitos da Lei Complementar n. ${ }^{\circ}$ 101/2000, em sede de veiculação de incentivos fiscais ambientais, cumpre abordar o Projeto de Lei n. ${ }^{\circ}$ 3.470/2008, que institui o Programa Empresa Consciente, segundo o qual as empresas podem deduzir do IRPJ parcela dos gastos com projetos ecológicos, com a redução da poluição ambiental ou com a valorização do trabalhador.

Nos termos da citada proposta, as deduções em tela não poderão ultrapassar o limite de $4 \%$ do imposto devido, relativamente a cada projeto, e 10\% do imposto devido, no que se refere ao total de projetos ${ }^{387}$.

O relator do Projeto, a despeito de ser favorável ao Programa, constatando que sua instituição geraria renúncia de receitas e considerando o fato de o estímulo ser conferido no âmbito do IRPJ (imposto não excepcionado do regime jurídico da Lei n. ${ }^{\circ}$ 101/2000), sugeriu que fossem incluídas disposições que permitissem a adequação do projeto às imposições contidas na Lei de Responsabilidade Fiscal, salvaguardando assim a sua juridicidade e a sua compatibilidade financeira e orçamentária.

\footnotetext{
${ }^{387}$ Vale pontuar que a mencionada dedução tem como condição a comprovação de recolhimento de impostos e contribuições federais. Na hipótese de fraude, a empresa arca com multa correspondente a duas vezes o valor da vantagem auferida indevidamente, além de serem cabíveis sanções penais.
} 
De fato, a emenda apresentada pelo relator determinou que as compensações das renúncias de receitas oriundas da implantação do programa "Empresa Consciente" estivessem previstas nos projetos de lei relativos às diretrizes orçamentárias e aos planos plurianuais, bem como ressaltou que o programa somente entraria em vigor quando do atendimento dessas exigências.

Por força dos comandos contidos na mencionada emenda, poder-se-á demonstrar que a renúncia de receitas decorrentes do Programa "Empresa Consciente" está prevista na estimativa da receita da lei orçamentária, de sorte a não comprometer as metas de resultados fiscais.

Por seu turno, o Projeto de Lei n. ${ }^{o}$ 3.873/2012, que autoriza a dedução do IRPJ e CSLL para as pessoas jurídicas que patrocinarem os projetos ambientais incluídos na programação da Conferência Rio +20 , previu expressamente a inclusão do valor estimado da renúncia no demonstrativo que acompanha o projeto da lei orçamentária, nos seguintes termos: "O Poder Executivo estimará o montante da renúncia fiscal decorrente desta Lei e o incluirá no demonstrativo que acompanhará o projeto da lei orçamentária cuja apresentação se der após decorridos 60 dias da publicação desta Lei”.

Nota-se, pois, que a preferência tem sido por fazer constar os valores renunciados no orçamento, em vez de prever a elevação da carga tributária.

\subsection{Síntese dos parâmetros e limites para a criação de incentivos fiscais ambientais no Brasil}

Apresentar-se-á, na sequencia, a síntese dos parâmetros e limites para a veiculação de incentivos fiscais ecológicos, os quais buscam, a um só tempo, assegurar a concretização do objetivo de defesa do meio ambiente e evitar a invasão a outros princípios constitucionais. A sistematização ora elaborada encontra-se ajustada aos desígnios constitucionais, tendo sido cunhada a partir da interpretação dos diplomas legais pátrios e da jurisprudência e doutrina nacional e estrangeira.

Competência e Norma instituidora: 
a) Compete à União instituir normas gerais sobre a defesa do meio ambiente, de caráter nacional e com vinculação aos Estados, Distrito Federal e Municípios. Por seu turno, os citados entes políticos, a par de terem de respeitar as disposições gerais expedidas pela União, estão autorizados a instituir incentivo fiscal ecológico, por deterem competência comum para "proteger o meio ambiente e combater a poluição em qualquer de suas formas" (art. 23 da CF/1988).

b) O incentivo fiscal ecológico deve ser veiculado por lei ordinária, instituída pela União, Estados, Distrito Federal ou Municípios e voltada especificamente à regulação dos correspondentes estímulos tributários (§ $66^{\circ}$ do art. 150 da CF). Nesse sentido, é vedada a introdução de incentivo fiscal ambiental no bojo de um diploma legal que versa sobre diversas outras matérias e assuntos.

c) A lei instituidora do incentivo fiscal ambiental deve contemplar toda a conformação do incentivo concedido. Assim, deve ser apontado qual o tipo e os limites do tratamento diferenciado proposto (isenção, redução da base de cálculo, diferimento), os fatos e os sujeitos alcançados pela norma, o período de duração, os requisitos, a forma de concessão e demais aspectos que o edificam. A lei poderá remeter a ato normativo a regulamentação do incentivo por ela já delineado, não podendo autorizar que sejam traçadas as suas linhas estruturantes de modo a conferir a órgão executivo uma carta em branco.

d) Tendo em vista que o incentivo ecológico demanda conhecimento técnico sobre o tema, não há óbice para que a lei condicione o seu deferimento a ato concessório expedido por órgão especializado.

e) A lei que institui o incentivo fiscal ambiental deve contemplar comando voltado à concretização do objetivo constitucional de proteção do meio ambiente, estimulando, assim, comportamentos ambientalmente orientados.

f) É recomendável que a lei instituidora do incentivo fiscal ambiental albergue conceitos indeterminados e cláusulas gerais, já que as questões ambientais se relacionam com a realidade econômica e tecnológica, cuja constante mutabilidade requer que as normas que as regulamentam, para serem fiéis ao seu escopo, ajustem-se aos novos cenários.

Princípios constitucionais da igualdade, proporcionalidade, capacidade contributiva e livre concorrência:

g) $\mathrm{O}$ incentivo fiscal ecológico contempla tratamento tributário diferenciado entre contribuintes, em função de critérios ambientais (redução do impacto ambiental, de que trata o art. 170, VI, da Lei Maior). Assim, para que não haja desvirtuamento do instituto e violação à isonomia, cumpre, de início, confirmar se o aludido tratamento discriminatório alcançará bem, serviço ou meio de produção que efetivamente representa um ganho ambiental. Tal constatação, em muitos casos, requer análise técnica do balanço energético, ciclo de vida, dentre outras avaliações específicas.

h) $\mathrm{O}$ respeito ao princípio da igualdade exige, ainda, que o incentivo fiscal ambiental seja compatível com os demais princípios, bens e valores constitucionais, que não podem sofrer restrições desproporcionais em 
virtude da criação do instituto vertente. Assim, é necessário que este seja aprovado no teste da proporcionalidade, composto pelo exame dos seus três subprincípios: adequação, necessidade e proporcionalidade no sentido estrito.

i) A análise da proporcionalidade do incentivo demanda avaliações técnicas ambientais e econômicas, tais como a investigação da elasticidade da demanda, identificação econômica do quantum ótimo a ser desonerado etc.

j) O exame da adequação deverá investigar se o estímulo contido no incentivo fiscal ecológico é idôneo a alcançar o fim de proteção ambiental perseguido, ou seja, se é apto a fomentar o comportamento sustentável apontado pela norma.

k) No exame de adequação deve-se perquirir se a conduta ambientalmente orientada é passível de ser estimulada (trata-se de demanda elástica? Comportamento passível de ser alterado?) e, em caso positivo, cumpre investigar se seria dispensável o incentivo, pelo fato de a conduta desejada já ser amplamente difundida. No estágio atual de desenvolvimento e conscientização ambiental, em regra, é adequada a criação dos citados instrumentos fiscais quando os produtos, serviços e meios de produção mais sustentáveis são: i) considerados pelo mercado como "alternativos" aos tradicionais, ii) elásticos e iii) desprovidos de vantagem competitiva.

1) Nesse contexto, o incentivo fiscal tanto pode ser adequado para contribuir com a redução do impacto ambiental imposta por leis ambientais, conferindo maior efetividade à correlata norma, quanto para fomentar condutas mais sustentáveis, que vão além das exigências legais. Em ambas as situações, o estímulo físcal se presta para atenuar o ônus adicional incorrido pelo contribuinte.

m) É possível, todavia, que o comportamento sustentável demande estímulo fiscal, ainda que conte com plena adesão do mercado, no caso de ser necessária a aceleração do curso natural deste, reduzindo-se imediatamente determinado passivo ambiental para mitigação de risco. Geralmente tal situação ocorre durante uma crise ambiental específica.

n) O subprincípio da necessidade impõe que se examine se há, na situação concreta, outro instrumento igualmente apto a alcançar a proteção do meio ambiente, porém, de maneira menos onerosa. Há de comparar o incentivo fiscal ecológico com outros instrumentos e verificar qual veículo irá restringir menos os demais princípios afetados.

o) Análises técnicas comparativas devem avaliar se os incentivos fiscais ambientais são os instrumentos de intervenção sobre a economia que menor prejuízo geram, por exemplo, à igualdade, à livre-iniciativa e à livre concorrência.

p) $\mathrm{Na}$ etapa do teste da proporcionalidade em sentido estrito já se tem a certeza da sua idoneidade e da sua necessidade para alcançar a defesa ambiental, cabendo avaliar se os efeitos negativos causados superam os positivos.

q) As vantagens podem ser potencializadas se for agregado outro fim extrafiscal ao incentivo ecológico, tal como um objetivo social ou econômico. Em tais hipóteses, as vantagens ganharão mais peso, bem como o aspecto quantitativo poderá ter maior elasticidade. 
r) A aprovação no teste da proporcionalidade é feita com base na análise fática e jurídica subjacente. Em se tratando de questão ambiental, as mudanças da realidade concreta são velozes e incessantes, pelo que os estímulos fiscais devem ser concedidos por prazo certo ou, ao menos, por prazo indeterminado com previsão de reavaliação periódica.

s) Por se encontrar no âmbito da tributação, o incentivo fiscal ecológico, a princípio, atenderá à capacidade contributiva na sua dimensão objetiva. Entretanto, uma vez que seu escopo primordial é a proteção do meio ambiente, não será possível compatibilizar, em todos os casos, este objetivo extrafiscal com o referido princípio no seu viés subjetivo, sendo admitida a concessão de tratamento tributário vantajoso a contribuinte que adota práticas sustentáveis previstas pela lei, independentemente da investigação acerca da sua capacidade contributiva.

t) O princípio da livre concorrência impede que o incentivo fiscal ecológico veicule estímulo desmedido que torne, de maneira artificial, a atividade verde altamente atrativa e as atividades tradicionais inviáveis. É necessário que se conceda vantagem fiscal em montante adequado ao fomento da atividade desejada e que a duração desta seja limitada à concretização da proteção ambiental buscada.

u) As situações de crise ambiental podem justificar uma restrição maior ao princípio da livre concorrência, permitindo que se concedam vantagens fiscais a atividades verdes, ainda que estas venham a abalar a igualdade de condições entre concorrentes.

Aplicação do regime jurídico imposto pela Lei de Responsabilidade Fiscal:

v) A lei veiculadora de incentivo fiscal ambiental deve identificar o impacto para o orçamento público decorrente do tratamento tributário diferenciado que institui, apresentando estimativa do valor que se deixa de arrecadar. Havendo renúncia de receita, cabe demonstrar que esta já se encontra prevista na Lei de Diretrizes Orçamentárias. O incentivo não poderá produzir efeitos até que se adote tal providência ou que se eleve a carga tributária de modo a garantir a compensação das correlatas perdas na arrecadação. 


\section{CONCLUSÃO}

O presente estudo procurou demonstrar que, desde a Revolução Industrial, o império do baixo custo, do alto consumo e da produção em escala vem sendo responsável por drástica redução dos ativos ambientais, desenfreada poluição e transformações irreversíveis no meio ambiente, dentre elas, as mudanças do clima mundial. E, neste cenário de crise ambiental, a adoção de novos padrões de produção, circulação de bens e de consumo tornou-se uma imposição para que o próprio sistema econômico vigente tenha continuidade.

Surge, portanto, a necessidade de se migrar de uma economia tradicional para uma economia verde, voltada, a um só tempo, ao atendimento das necessidades humanas, à igualdade social e à proteção dos ativos ambientais; com a consequente incorporação da ideia de desenvolvimento sustentável.

A esse respeito, foi evidenciado que, nas últimas 4 décadas, existiram inúmeras Conferências Internacionais, elaboraram-se robustos documentos e editaram-se diplomas legais voltados à questão ambiental. Contudo, não se logrou encontrar uma solução efetiva para os problemas relacionados ao meio ambiente.

Constatou-se que a tecnologia vem sendo instada a trazer inovações que diminuam o impacto ambiental e que governos, sociedade e corporações, cujo envolvimento é indispensável para esta ruptura de paradigmas, vêm incluindo o componente ambiental nas suas decisões, embora num ritmo muito aquém do necessário.

Foi pontuada a existência de diversos instrumentos que vêm sendo utilizados com o intuito de reduzir a poluição, aumentar a eficiência energética e maximizar o aproveitamento dos recursos naturais. Assim, dentre outros veículos, normas introduzem proibições para certas atividades nocivas ao meio ambiente, limites à emissão de gases de efeito estufa são fixados, a poluição e as atividades potencialmente poluidoras são oneradas e incentivos fiscais ambientais são instituídos para o fomento de comportamentos ambientalmente orientados.

Com o escopo de identificar o conteúdo e o alcance dos incentivos fiscais ambientais e formular balizas à sua aplicação em âmbito nacional, examinou-se a tutela 
constitucional do meio ambiente e a tributação na vida social e econômica do país, com ênfase na tributação com predominância de fins extrafiscais.

Verificou-se que a Constituição Federal de 1988 contemplou a questão ambiental em diversas passagens do seu texto, tendo estabelecido a defesa do meio ambiente como capítulo específico do título que aborda a ordem social (art. 225 da CF/1988), bem como a incluiu no rol dos princípios conformadores da ordem econômica (art. 170 da CF/1988).

Deveras, estando a proteção do meio ambiente albergada tanto na ordem social quanto na ordem econômica, revelou-se nítido o escopo constitucional de efetivar um desenvolvimento sustentável, que pressupõe uma atividade econômica ajustada a essa diretriz.

Sob tal perspectiva e considerando que o estágio atual de crise ambiental demanda que se acelere o ritmo das transformações rumo a uma produção e a um consumo mais sustentáveis, foram investigados os fundamentos para que o ente estatal viesse a assumir papel indutor, intervindo sobre a economia sob este enfoque.

Com efeito, observou-se ser possível a intervenção estatal sobre o domínio econômico para corrigir disfunções do mercado e para moldar a economia, em busca de melhores resultados, considerando-se os objetivos traçados pela Constituição.

Assim sendo, contatou-se que, na seara ambiental, o Estado pode agir para corrigir distorções causadas por externalidades negativas e positivas, que consubstanciam falhas de sinalização do mercado identificadas quando os custos ou os benefícios ambientais pertinentes a certa atividade não se encontram computados no seu cálculo econômico. Além disso, encontra-se o Estado autorizado a criar políticas econômicas voltadas à incorporação do princípio da defesa do meio ambiente nas atividades econômicas.

Por sua vez, foi visto que, no âmbito tributário, o ente estatal pode intervir sobre a economia, seja aumentando a carga tributária, seja atenuando a tributação, em prol da proteção ambiental.

No caso especifico do incentivo fiscal ecológico, são concedidos tratamentos tributários mais vantajosos (por meio de isenção, crédito presumido, depreciação acelerada, diferimento etc.) para o contribuinte que adotar a conduta prevista pela respectiva lei instituidora. A redução do tributo ou a postergação do seu pagamento podem servir para compensar o contribuinte que incorrer em gastos revertidos em benefícios para 
a sociedade em termos de sustentabilidade (correção de externalidade positiva) ou podem estar inseridos em programa de governo voltado à redução dos impactos ambientais.

Nesta senda, uma vez que se está diante de um Estado Social e Democrático de Direito, no qual a carga tributária abarca importante parcela da riqueza nacional por visar à concretização da justiça distributiva e à realização dos mais variados objetivos sociais e econômicos, a instituição de incentivo fiscal de cunho ambiental, que contempla vantagem fiscal adequadamente dosada, tende a atrair muitos contribuintes, induzindo-os à prática de condutadas ecologicamente orientadas.

O mencionado estímulo fiscal maximizará a sua pertinência e conformidade com a realidade fático-jurídica posta quanto maior for o seu imbricamento com a questão social e econômica.

Quanto mais evidente for o incremento dos índices econômicos e sociais promovidos pelo estímulo fiscal ambiental, maior será a sua compatibilidade com o sistema jurídico brasileiro e a possibilidade de ser concedido na máxima medida possível.

Delineados os contornos do instituto em tela, passou-se a tratar dos limites, à luz do ordenamento jurídico nacional, a que a sua criação deverá estar adstrita.

Além de limitações atinentes à legalidade, à capacidade contributiva, à competência e ao equilíbrio orçamentário, foram estabelecidas balizas relacionadas à igualdade e à livre concorrência, voltadas à aferição: do efetivo ganho ambiental experimentado a partir da adoção da conduta selecionada, da real capacidade de a conduta desejada ser estimulada via incentivo fiscal, da existência de outros meios menos restritivos para efetivar a defesa do meio ambiente, do período de duração apropriado para que se implemente o comportamento sustentável e da graduação ideal da vantagem fiscal, que lhe permita induzir condutas, sem causar distorções quanto aos comportamentos não incentivados.

Estruturou-se o manejo da proporcionalidade de sorte a permitir ao operador do Direito sopesar, com base nos subprincípios da adequação, necessidade e proporcionalidade em sentido estrito, as mais diversas variáveis e os princípios conflitantes que a criação do instituto atrai. O objetivo é que a referida ponderação promova a veiculação de incentivo: i) capaz de estimular condutas que gerem um ganho ambiental, ii) necessário ao alcance de tal fim e iii) que resulte em mais vantagens do que desvantagens.

Com efeito, a sistematização de limites e parâmetros para a instituição de incentivos fiscais ambientais elaborada no trabalho em tela, buscou trazer diretrizes para 
inibir tratamentos tributários diferenciados que não promovem a efetiva proteção do meio ambiente ou que sejam incompatíveis com os demais objetivos constitucionais.

A preocupação que se teve ao cunhar os parâmetros vertentes foi a de fortalecer o instituto e afastá-lo das críticas que lhe são dirigidas. Conforme exposto, esse instrumento é uma realidade no Brasil e em diversos outros países, sendo imperioso que a sua utilização esteja em consonância com os ditames jurídicos aplicáveis e atinja o seu fim de proteção do meio ambiente, na maior medida possível.

Neste compasso, a aplicação dos referidos limites não deve ser desvirtuada de maneira a transformá-los em entraves à instituição de incentivos fiscais ambientais. Ao contrário, firmes em tais parâmetros, devem os entes políticos arrecadantes valer-se deste instrumental, extraindo resultados relevantes em termos de sustentabilidade. Isto porque, caso as medidas em prol do meio ambiente sejam tímidas e ineficazes, os problemas ambientais serão acirrados, o que ensejará medidas mais incisivas que, inevitavelmente, afetarão em grande medida outros fins constitucionais. 


\section{REFERÊNCIAS}

ABRAMOVAY, Ricardo. Desenvolvimento sustentável: qual a estratégia para o Brasil? Revista Novos Estudos, São Paulo, n. 87, p. 109, jul. 2010.

AGENZIA DEL TERRITORIO NELL'AGENZIA DELLE ENTRATE. Disponível em: $<$ http://www.agenziaentrate.gov.it>. Acesso em: 18 nov. 2012.

AGUILlAR, Fernando Herren. Direito econômico: do direito nacional ao direito supranacional. 2. ed. São Paulo: Atlas, 2009.

ALMEIDA, Francisco Carlos Ribeiro. A renúncia de receita como fonte alternativa de recursos orçamentários. Revista do Tribunal de Contas do Estado de Minas Gerais, Belo Horizonte, v. 41, n. 4, out./-ez. 2001.

- Uma abordagem estruturada da renúncia da receita pública federal. Revista do Tribunal de Contas da União, Brasília, v. 31, n. 84, abr-jun. 2000.

AMADO, Frederico Augusto Di Trindade. Direito ambiental esquematizado. 3. ed. Rio de Janeiro: Forense; São Paulo: Método, 2012.

AMAR, Jorge; ECCLES, Robert G.; SERAFEIM, George. Brasil: uma sociedade sustentável. Disponível em: <http://www.ideiasustentavel.com.br/2012/06/brasil-umasociedade-sustentavel/>. Acesso em: 29 ago. 2012.

AMARO, Luciano da Silva. Direito tributário brasileiro. 15. ed. São Paulo: Saraiva, 2009.

ATALIBA, Geraldo; GONÇALVES, José Artur Lima. Crédito-prêmio de IPI - direito adquirido - recebimento em dinheiro. Revista de Direito Tributário, São Paulo, v. 15, n. 55, p. 167, jan.-mar. 1991.

AUSTRALIAN GOVERNMENT. Australian taxation office. Disponível em: $<$ http://www.ato.gov.au>. Acesso em: 30 jul. 2012.

ÁVILA, Humberto. Benefícios fiscais inválidos e a legítima expectativa do contribuinte. Revista Eletrônica de Direito Administrativo Econômico, Salvador, Instituto de Direito Público da Bahia, n. 4, nov.'dez. 2005; jan. 2006. Disponível em: $<$ http://direitodoestado.com.br>. Acesso em: 10 out. 2011.

—. Teoria da igualdade tributária. 2. ed. São Paulo: Malheiros, 2009.

BALEEIRO, Aliomar. Direito tributário brasileiro. 17. ed. Rio de Janeiro: Forense, 1999. 
_. Limitações ao poder de tributar. 7. ed. Rio de Janeiro: Forense, 1999.

—. Uma introdução à ciência das finanças. 14. ed. Rio de Janeiro: Forense, 1987.

BANDEIRA DE MELLO, Celso Antônio. O conteúdo jurídico do princípio da igualdade. 3. Ed. São Paulo: Malheiros, 2003.

BARRETO, Aires Fernandino. Vedação ao efeito de confisco. Revista de Direito Tributário, v. 64, n. 98, set. 1994.

BARRETO, Aires F.; BARRETO, Paulo Ayres. Imunidades tributárias: limitações constitucionais ao poder de tributar. São Paulo: Dialética, 1999.

BARROSO, Luís Roberto. O direito constitucional e a efetividade de suas normas: limites e possibilidades da Constituição brasileira. 7. ed. Rio de Janeiro: Renovar, 2003.

BECKER, Alfredo Augusto. Teoria geral do direito tributário. 3. ed. São Paulo: Lejus, 1998.

BECKER, Fernando; CAZORLA, Lui Maria; MARTÍNEZ-SIMANCAS, Julián (Dirs.). Tratado de tributación medioambiental. Pamplona: Aranzandi, 2008. v. 2.

BELASTINGDIENST. Disponível em: <http://www.belastingdienst.nl>. Acesso em: 15. 2012.

BERLIRI, Antonio. Scritti Scelti di diritto tributário. Milano: Giuffrè, 1990.

BOMFIM, Diego. Tributação e livre concorrência. São Paulo: Saraiva, 2011.

BORGES, José Souto Maior. Isenções tributárias. 1. ed. São Paulo: Sugestões Tributárias, 1969.

Teoria geral da isenção tributária. 3 ed. São Paulo: Malheiros, 2001.

BORRERO MORO, Cristóbal José. Límites del derecho comunitario a los tributos ambientales. Noticias de la Unión Europea, Valencia, ano 17, n. 193, feb. 2001.

BOtTAllo, Eduardo Domingos. Mesa de Debates C. Tributação, Ecologia e Meio Ambiente. (XIII Congresso Brasileiro de Direito Tributário). Revista de Direito Tributário, São Paulo, n. 78, 1999.

BRANDÃO, Renata Figueirêdo. Vedação ao tributo com efeito de confisco. 2007. Dissertação (Mestrado) - Faculdade do Direito, Universidade Federal da Bahia, Salvador.

BRAZUNA, José Luis Ribeiro. Defesa da concorrência e tributação: à luz do art. 146-A da Constituição. São Paulo: Quartier Latin, 2009. (Série Doutrina tributária, v. 2.) 
BRITO, Edvaldo Pereira (Coord.). Doutrinas essenciais de direito tributário. São Paulo: RT, 2011. v. 2, v. 3 e v. 4.

CANADA REVENUE AGENCY. Disponível em: <http://www.cra-arc.gc.ca/>. Acesso em: 15 out. 2012.

CANOtIlHO, José J.G. Direito constitucional e teoria da Constituição. Coimbra: Almedina, 2003.

CARrAZZA, Roque Antonio. Curso de direito constitucional tributário. 22. ed. São Paulo: Malheiros, 2006.

CARVAlHO, Paulo de Barros. Curso de direito tributário. 23. ed. São Paulo: Saraiva, 2010.

CASSONE, Vittorio. Interpretação no direito tributário: teoria e prática. São Paulo: Atlas, 2004.

CATÃO, Marcos André Vinhas. Regime jurídico dos incentivos fiscais. Rio de Janeiro: Renovar, 2004.

CAZORLA, Lui Maria; MARTÍNEZ-SIMANCAS, Julián. (Coord.). Tratado de tributación medioambiental. Pamplona: Aranzadi, 2008. v. 2.

COBOS GOMES, José María. Traytoria y principios de la tributación ambiental em la Unión Europeia. In: BECKER, Fernando; CAZORLA, Lui Maria; MARTÍNEZSIMANCAS, Julián (Dir.). Tratado de tributación medioambiental. Pamplona: Aranzandi, 2008. v. 2.

COÊLHO, Sacha Calmon Navarro. Curso de direito tributário brasileiro. 9. ed. Rio de Janeiro: Forense, 2007.

CORREIA NETO, Celso B. Instrumentos fiscais de proteção ambiental. Revista Direito Tributário Atual, São Paulo, n. 22, p. 140-160, 2008.

COSTA, Regina Helena. Curso de direito tributário: Constituição e Código Tributário Nacional. São Paulo: Saraiva, 2009.

—. Principio da capacidade contributiva. São Paulo: Malheiros, 1996.

CRESPO, Samyra. Enfrentando o desafio da produção e do consumo sustentáveis. ALMEIDA, Fernando (Org.). Desenvolvimento sustentável 2012 - 2050: visão, rumos e contradição. Rio de Janeiro: Elsevier, 2012. 
DE SANTI, Eurico Marcos Diniz. Lançamento tributário. 2. ed. São Paulo: Max Limonad, 1999.

DERANI, Cristiane. Direito ambiental econômico. 3. ed. São Paulo: Saraiva, 2009.

DERZI, Misabel Abreu Machado. Nota de atualização a Aliomar Baleeiro. Direito tributário brasileiro. 11. ed. Atualizada por Mizabel Abreu Machado Derzi. Rio de Janeiro: Forense, 2003.

ELALI, André. Incentivos fiscais internacionais: concorrência fiscal, mobilidade financeira e crise do Estado. São Paulo: Quartier Latin, 2010.

FANUCCHI, Fábio. Curso de direito tributário brasileiro. São Paulo: Resenha Tributária, 1976.

FELL, Elizangela Treméa; TREMÉA, Estela Maria. O princípio do protetor-recebedor e o proambiente: Limites e possibilidade da compensação financeira. Ambito Jurídico, Rio Grande, v. 11, n. 51, mar. 2008. Disponível em: $<$ http://www.ambitojuridico.com.br/site/index.php?n_link=revista_artigos_leitura\&artigo_ id=2482>. Acesso em: set. 2012.

FERNÁNDEZ DE TROCÓNIZ ROBLES, Borja. La tributación medioambiental en Gran Bretaña. In: BECKER, Fernando; CAZORLA, Lui Maria; MARTÍNEZ-SIMANCAS, Julián (Dir.). Tratado de tributación medioambiental. Pamplona: Aranzandi, 2008. v. 2.

FIGUEIREDO, Marcelo. Mesa de Debates C. Tributação, Ecologia e Meio Ambiente. (XIII Congresso Brasileiro de Direito Tributário). Revista de Direito Tributário, São Paulo, n. 78, 1999.

FINEP - $\quad$ Brasil sustentável. Disponível $<$ http://www.finep.gov.br/pagina.asp?pag=25.12>. Acesso em: 20 nov. 2012.

FIORILO, Celso Antônio Pacheco. Direito ambiental tributário. São Paulo: Saraiva.

FISCHER, Octavio Campos. Tributos e direitos fundamentais. São Paulo: Dialética, 2004.

FONROUGE, Giuliani. Derecho financiero. 7. ed. Buenos Aires: Depalma, 2001. v. 1.

GOUVÊA, Marcus de Freitas. A extrafiscalidade no direito tributário. Belo Horizonte: Del Rey, 2006.

GOVERNANCE of Climate Change in Developing Countries (The). A Report on International and Domestic Climate Change Politics in China, Brazil, Ethiopia and Tuvalu. Oct. 
$<$ http://www.afd.fr/webdav/site/afd/shared/PUBLICATIONS/RECHERCHE/Scientifiques/ A-savoir/15-VA-A-Savoir.pdf>.

GRAU, Eros Roberto. A ordem econômica na Constituição de 1988. 11. ed. São Paulo: Malheiros, 2006.

—. Elementos de direito econômico. São Paulo: RT, 1981.

- Equilíbrio ambiental no espaço urbano. Revista da Procuradoria-Geral do Município de Porto Alegre, Porto Alegre, n. 8, p. 65-75, mar. 1995.

GROFF, Leandro Morais. Isenção, alíquota zero e o princípio da não cumulatividade. Revista Tributária e de Finanças Públicas, São Paulo, v. 15, n. 76, p. 161-174, set.-out. 2007.

GUIMARÃES, Renan Eschiletti Machado. Incentivos fiscais no direito ambiental e a efetivação do princípio do protetor-recebedor na política nacional de resíduos sólidos (Lei $n .^{o}$ 12.305/2010). Porto Alegre: Buqui, 2012.

HARADA, Kiyoshi. Responsabilidade fiscal: Lei complementar n. 101/2000 comentada e legislação correlata anotada. São Paulo: Juarez de Oliveira, 2002.

HENRIQUES, Elcio Fiori. Os beneficios fiscais no direito financeiro e orçamentário: o gasto tributário no direito brasileiro. São Paulo: Quartier Latin, 2010.

HERRERA MOLINA, P. Derecho tributario ambiental. Madrid: Marcial Pons, 2000.

HM REVENUE \& CUSTOMS. Disponível em: <http://www.hmrc.gov.uk/>. Acesso em: 15 out. 2012.

HORVATH, Estevão. Contribuição de intervenção no domínio econômico. São Paulo: Dialética, 2009.

—. O princípio do não confisco no direito tributário. São Paulo: Dialética, 2002.

HUBERMAN, Leo. História da riqueza do homem. Rio de Janeiro: LTC, 1986.

ICHIHARA, Yoshiaki. Imunidades tributárias. São Paulo: Atlas, 2000.

LAVADAS, Kostas. Politics, subisidies and competition: the new politics of state intervention in the European Union. Cheltenham: Edward Elgar, 1999.

LEGIFRANCE. Disponível em: <http://www.impots.gouv.fr>. Acesso em: 15.2012

LEITE, José Rubens Morato; AYALA, Patryck de Araújo. Direito ambiental na sociedade de risco. 2. ed. rev. atual. e ampl. Rio de Janeiro: Forense Universitária, 2004. 
-; MELO, Melissa Ely. As funções preventivas e precaucionais da responsabilidade civil por danos ambientais. In: PES, João Hélio Ferreira; OLIVEIRA, Rafael Santos de (Coord.). Direito ambiental contemporâneo: prevenção e precaução. Curitiba: Juruá, 2009.

LEMGRUBER, Andréa. A competição tributária em economias federativas: aspectos teóricos, constatações empíricas e uma análise do caso brasileiro. 1999. Dissertação (Mestrado) - Departamento de Economia. UNB. Disponível em: $<$ www.federativo.bndes.gov.br>.

LIGTERINGEN, Ernst. Caminhando e conversando: stakeholders, juntos, a caminho de uma economia verde. In: ALMEIDA, Fernando (Org.). Desenvolvimento sustentável 2012-2050: visão, rumos e contradição. Rio de Janeiro: Elsevier, 2012.

LIMA, Ricardo Seibel de Freitas. Livre concorrência e dever de neutralidade tributária. 2005. Dissertação (Mestrado) - Faculdade de Direito da Universidade Federal do Rio Grande do Sul, Porto Alegre.

MACHADO, Celso Cordeiro. Limites e conflitos de competência tributária no direito brasileiro. Belo Horizonte: [s.n.], 1968.

MACHADO, Hugo de Brito. Não incidência, imunidades e isenções do ICMS. In: BRITO, Edvaldo Pereira (Coord.). Doutrinas essenciais de direito tributário. São Paulo: RT, 2011. v. 2 .

MARTÍNEZ-SIMANCAS, Julián. (Coord.). Tratado de tributación medioambiental. Pamplona: Aranzadi, 2008. v. 2.

MARTINS, Ives Gandra da Silva (Coord.). Imunidades tributárias. São Paulo: Centro de Extensão Universitária; Ed. Revista dos Tribunais, 1998. (Coleção Pesquisa tributária, Nova Série, v. 4).

et al. Curso de direito tributário. 7. ed. São Paulo: Saraiva, 2000.

—; PAVAN, Claudia Fonseca Morato. ICMS. Substituição tributária. Transferência de créditos autorizada por portaria. Inconstitucionalidade. Nulidade ex tunc. consequências. Revista Tributária e de Finanças Públicas, São Paulo, v. 45, jul. 2002.

- - ELALI, André; Marcelo Magalhães (Coord.). Incentivos fiscais: questões pontuais nas esferas federal, estadual e municipal. São Paulo: MP Ed., 2007.

MATTOS, Aroldo Gomes de. O imposto de renda frente ao ICMS remitido como subvenção para investimento. Revista Tributária e de Finanças Públicas, São Paulo, v. 15, abr. 1996. 
MITA, Enrico de. O princípio da capacidade contributiva. In: FERRAZ, Roberto Catalano Botelho (Coord.). Princípios e limites da tributação. São Paulo: Quartier Latin, 2005.

MORAES, Bernardo Ribeiro de. Imunidades tributárias. In: MARTINS, Ives Gandra da Silva (Coord.). Imunidades tributárias. São Paulo: Centro de Extensão Universitária; RT, 1998. (Coleção Pesquisa tributária, Nova Série, 4.)

MOTTA, Ronaldo Seroa da; SAYAGO, Daiane Ely. Propostas de instrumentos econômicos ambientais para a redução do lixo urbano e o reaproveitamento de sucatas no Brasil. Rio de Janeiro: IPEA, 1998. Disponível: <http://www.ipea.gov.br/pub/td/td0608.pdf,looo>. Acesso em: 7 nov. 2011.

NABAIS, José Casalta. O dever fundamental de pagar impostos: contributo para a compreensão do estado fiscal contemporâneo. Coimbra: Almedina, 1998.

- Tributos com fins ambientais. Revista Tributária e de Finanças Públicas, São Paulo, ano 16, v. 80, maio/jun. 2008.

NANOTECNOLOGIA. Disponível em: <http://pt.wikipedia.org/wiki/Nanotecnologia>. Acesso em: 27 fev. 2012.

NOBRE, Marcos. Desenvolvimento sustentável: origens e significado atual. In: AMAZONAS, Maurício de Carvalho (Org.). Desenvolvimento sustentável: a institucionalização de um conceito. Brasília: Ed. Ibama, 2002.

NOGUEIRA, Barbosa, Ruy. Curso de direito tributário. 7. ed. São Paulo: Saraiva, 1986.

—. Extrafiscalidade e a intervenção do Estado na vida econômica e social por meio da tributação. In: —. Curso de direito tributário. 7. ed. São Paulo: Saraiva, 1986.

NUNES, Cleucio Santos. Direito tributário e meio ambiente. São Paulo: Dialética, 2005.

NUSDEO, Ana Maria de Oliveira. Defesa da concorrência e globalização econômica (o controle da concentração de empresas). São Paulo: Malheiros, 2002.

—. Pagamento por serviços ambientais: sustentabilidade e disciplina jurídica. São Paulo: Atlas, 2012.

NUSDEO, Fábio. Curso de economia: introdução ao direito econômico. 6. ed. rev. e atual. São Paulo: RT, 2010.

OCDE. Écotaxes et Reforme Fiscale Verte. Reimpressão. Paris: OCDE, 1997.

- Green growth and sustainable development. Disponível em: $<$ http://www.oecd.org/greengrowth/keydocuments.htm>. Acesso em: 19 set. 2012 
- Taxation, innovation and the environment. Disponível em: $<$ www.oecd.org/publishing/corrigenda $>$. Acesso em: 15 ago. 2012.

- Towards Green Growth. Disponível em: $<$ http://www.oecd.org/greengrowth/48224539.pdf>. Acesso em: 19 set. 2012

OLIVEIRA, José Marcos Domingues de. Direito tributário e meio ambiente: proporcionalidade, tipicidade aberta, afetação da receita. Rio de Janeiro: Renovar, 1995.

Direito tributário e meio ambiente. 3. ed. Rio de Janeiro: Forense, 2007.

OLIVEIRA, Régis Fernandes. Curso de direito financeiro. São Paulo: Ed. Revista dos Tribunais, 2006.

ORTEGA, Rafael Calvo. Curso de derecho financiero. 9. ed. Madrid: Thompson-Civitas, 2005. v. 1. Derecho tributario, parte general.

PAIVA, Leila. Disciplina jurídica da extrafiscalidade. 1994. Dissertação (Mestrado) Faculdade de Direito, Universidade de São Paulo, São Paulo.

PEIXOTO, Marcelo Magalhães (Coord.). IPI: aspectos jurídicos relevantes. São Paulo: Quartir Latin, 2003.

PIERCE, David W.; TURNER. R. Kerry. Economics of natural resources and the environment. Maryland: The Johns Hopkins University Press, 1990.

PNUMA. Towards a green economy: pathways to sustainable development and poverty eradication - a synthesis for policy makers, 2011. Disponível em: $<$ www.unep.org/greeneconomy $>$.

PONTES, Helenílson Cunha. Direitos fundamentais do contribuinte. In: MARTINS, Ives Gandra da Silva (Coord.). Imunidades tributárias. São Paulo: Centro de Extensão Universitária; RT, 2000. (Coleção Pesquisa tributária, Nova Série, v. 6).

- O princípio da capacidade contributiva e a extrafiscalidade: uma conciliação possível e necessária. In: SCAFF, Fernando Facury (Coord.). Ordem econômica e social: estudos em homenagem a Ary Brandão de Oliveira. São Paulo: LTr, 1999.

PONTES DE MIRANDA, Francisco Cavalcanti. Questões forenses. Rio de Janeiro: Borsoi, [s.d.]. t. 3.

PORTO Seguro oferece mais pontos de coleta para reciclagem de óleo de cozinha, cartões, pilhas baterias. Disponível em: $<$ http://www.gebramseguros.com.br/blog/2012/09/03/porto-seguro-oferece-mais-pontos- 
de-coleta-para-reciclagem-de-oleo-de-cozinha-cartoes-pilhas-e-baterias $>$ Acesso em: 5 de set. 2012.

RIBEIRO, Maria de Fátima; DINIZ, Marcelo de Lima Castro. O direito ao crédito-prêmio do IPI. In: PEIXOTO, Marcelo Magalhães (Coord.). IPI: aspectos jurídicos relevantes. São Paulo: Quartier Latin, 2003.

SAINZ DE BUJANDA, Fernando. Teoíia de la exención tributaria: hacienda y derecho. Madrid: Instituto de Estudios Políticos, 1963. v. 3.

SCAFF, Fernando Facury (Coord.). Ordem econômica e social: estudos em homenagem a Ary Brandão de Oliveira. São Paulo: LTr, 1999.

—; TUPIASSU, Lise Vieira da Costa. Tributação e políticas públicas: o ICMS ecológico. In: TÔRRES, Heleno Taveira (Org.). Direito tributário ambiental. São Paulo: Malheiros, 2005.

SCHOUERI, Luís Eduardo. Normas tributárias indutoras e intervenção econômica. Rio de Janeiro: Forense, 2005.

—. Normas tributárias indutoras em matéria ambiental. In: TÔRRES, Heleno Taveira (Org.). Direito tributário ambiental, São Paulo: Malheiros, 2005.

- Z ZILVETI, Fernando Aurélio (Coord.). Direito tributário: estudos em homenagem a Brandão Machado. São Paulo: Dialética, 1998.

SEBASTIÃO, Simone Martins. Tributo ambiental. 1. ed. 6. reimpressão. Curitiba: Juruá, 2011.

SEIXAS FILHO, Aurélio Pitanga. Teoria e prática das isenções tributárias. Rio de Janeiro: Forense, 1989.

SERRANO ANTÓN, Fernando. La tributación medioambiental en la Unión Europea. In: BECKER, Fernando; CAZORLA, Lui Maria; MARTÍNEZ-SIMANCAS, Julián (Dirs.). Tratado de tributación medioambiental. Pamplona: Aranzandi, 2008. v. 2.

SILVA, José Afonso da. Curso de direito constitucional positivo. 28. ed. São Paulo: Malheiros, 2006.

SILVA, Vasco Pereira da. "Mais vale prevenir do que remediar": prevenção e precaução no direito do ambiente. In: PES, João Hélio Ferreira; OLIVEIRA, Rafael Santos de (Coord.). Direito ambiental contemporâneo: prevenção e precaução. Curitiba: Juruá, 2009. 
SOARES, Cláudia Dias. O direito fiscal do ambiente: o enquadramento comunitário dos auxílios de Estado a favor do ambiente. Coimbra: Almedina, 2003.

SOTO, Jorge. A química sustentável: desafios, dilemas e perspectivas. In: ALMEIDA, Fernando (Org.). Desenvolvimento sustentável 2012 - 2050: visão, rumos e contradição. Rio de Janeiro: Elsevier, 2012.

SOUSA, Rubens Gomes de. Compêndio de Legislação Tributária. Edição póstuma. São Paulo: Resenha Tributária, 1975

- IPI e as vendas de ativo fixo. I In: BRITO, Edvaldo Pereira (Coord.). Doutrinas essenciais de direito tributário. São Paulo: RT, 2011. v. 3.

SOUZA, Jorge Henrique de Oliveira. Tributação e meio ambiente. Belo Horizonte: Del Rey, 2009.

STATSMINISTERIET. Disponível em: <http://www.stm.dk/>. Acesso em: 15 out. 2012.

TAVARES, André Ramos. Direito constitucional econômico. São Paulo: Método, 2006.

TIKE, Klaus. Moral tributaria del Estado y de los contribuintes. Tradução Pedro M. Herrera Molina. Madrid: Marcial Pons, 2002.

TÔRRES, Heleno Taveira. Da relação entre competências constitucionais tributária e ambiental: os limites dos chamados tributos ambientais. In: - (Org.). Direito tributário ambiental. São Paulo: Malheiros, 2005.

(Org.). Direito tributário ambiental. São Paulo: Malheiros, 2005.

TORRES, Ricardo Lobo. O princípio da isonomia, os incentivos do ICMS e a jurisprudência do STF sobre a guerra fiscal. In: MARTINS, Ives Gandra; ELALI, André; Marcelo Magalhães (Coord.). Incentivos fiscais: questões pontuais nas esferas federal, estadual e municipal. São Paulo: MP Ed., 2007.

- Tratado de direito constitucional, financeiro e tributário. Rio de Janeiro: Renovar, 1999. v. 3.

—. Valores e princípios no direito tributário ambiental. In: TÔRRES, Heleno Taveira (Org.). Direito tributário ambiental. São Paulo: Malheiros, 2005.

-; SCHOUERI, Luís Eduardo; ZILVETI, Fernando Aurélio (Coord.). Direito tributário: estudos em homenagem a Brandão Machado. São Paulo: Dialética, 1998.

TRENNEPOHL, Terence Dorneles. Incentivos fiscais no direito ambiental: para uma matriz energética limpa e o caso do etanol brasileiro. 2. ed. São Paulo: Saraiva, 2011. 
—. Incentivos tributários e meio ambiente: a sustentabilidade ambiental e o direito tributário. In: MARTINS, Ives Gandra; ELALI, André; Marcelo Magalhães (Coord.). Incentivos fiscais: questões pontuais nas esferas federal, estadual e municipal. São Paulo: MP Ed., 2007.

VEIGA, José Eli da. Economia em transição. In: ALMEIDA, Fernando (Org.). Desenvolvimento sustentável 2012 - 2050: visão, rumos e contradição. Rio de Janeiro: Elsevier, 2012.

VISION \& Objectives. Disponível em: <http://www.arboranano.ca/visionobjectives.aspx>. Acesso em: 12 nov. 2012.

XAVIER, Alberto. Tipicidade da tributação, simulação e norma antielisiva. São Paulo: Dialética, 2001.

YOSHIDA, Consuelo Yatsuda Moromizato. Tributação e políticas públicas: o ICMS ecológico. In: TÔRRES, Heleno Taveira (Org.). Direito tributário ambiental. São Paulo Malheiros, 2005.

ZILVETI, Fernando Aurélio. Princípios de direito tributário e a capacidade contributiva. São Paulo: Quartier Latin, 2004.

\section{LEGISLAÇÃo}

ASSEMBLEIA LEGISLATIVA DO ESTADO DE PÉRNAMBUCO. Projeto de Lei 872/2012. Cria o Programa de Sustentabilidade na Atividade Produtiva do Estado de Pernambuco - $\quad$ PESUSTENTÁVEL. Disponível em: $<$ http://www.alepe.pe.gov.br/paginas/verprojeto.php?id=3598\&paginapai=3576\&numero= 872\%2F2012>. Acesso em: 09 out. 2012.

BRASIL. Câmara dos Deputados. Projeto de Lei Complementar PLC 73/2007. Propõe uma Reformulação Tributária Ecológica, a fim de regulamentar o artigo 146-A, da Constituição Federal, instituir os princípios da essencialidade e do diferencial tributário pela sustentabilidade ambiental e oneração das emissões de gases de efeito estufa, e criar a taxação sobre o carbono (carbon tax), na forma de Contribuição de Intervenção no Domínio Econômico, para a sustentabilidade ambiental e a mitigação do aquecimento global. Disponível em: $<$ http://www.camara.gov.br/proposicoesWeb/fichadetramitacao?idProposicao=354998>. Acesso em: 3 jan. 2012. 
—. Câmara dos Deputados. Projeto de Lei PL 3.674/2012. Cria incentivos para a abertura e funcionamento da "Primeira Empresa", da "Primeira Empresa para Economia Verde", e dá outras providências. Disponível em: $<$ http://www.camara.gov.br/proposicoesWeb/fichadetramitacao?idProposicao=541085>. Acesso em 9 out. 2012.

—. Câmara dos Deputados. Projeto de Lei PL 5.974/2005. Dispõe sobre incentivos fiscais para projetos ambientais. Disponível em: $<$ http://www.camara.gov.br/proposicoesWeb/fichadetramitacao?idProposicao=301799 $>$. Acesso em: 3 jan. 2012.

—. Câmara dos Deputados. Projeto de Lei PL n. ${ }^{\circ}$ 1.428/2011. Institui benefício físcal a empresas que apresentem projetos de conservação e proteção de parques de alta relevância ambiental previamente aprovados pelo Ministério do Meio Ambiente. Disponível em: $<$ http://www.camara.gov.br/proposicoesWeb/fichadetramitacao?idProposicao=503589 $>$. Acesso em: 9 set. 2012.

—. Câmara dos Deputados. Projeto de Lei PL n. ${ }^{\circ}$ 3.873/2012. Institui incentivo fiscal para projetos ambientais e projetos culturais e artísticos de conteúdo ecológico integrantes da programação da Conferência Internacional Rio+20. Disponível em: $<$ http://www.camara.gov.br/proposicoesWeb/fichadetramitacao?idProposicao=544765 $>$. Acesso em: 9 set. 2012.

—. Câmara dos Deputados. Projeto de Lei PL n. ${ }^{o}$ 7.224/2010. Concede incentivo fiscal do Imposto sobre a Renda às pessoas físicas ou jurídicas que implantarem projetos de reflorestamento e florestamento e de preservação do meio ambiente. Disponível em: $<$ http://www.camara.gov.br/proposicoesWeb/fichadetramitacao?idProposicao=474940>. Acesso em: 9 set. 2012.

BRASIL. Senado Federal. Projeto de Lei PLN n. ${ }^{\circ}$ 44/2009. Concede isenção do Imposto sobre Produtos Industrializados aos veículos de passageiros e mistos movidos a tração elétrica. Disponível em: $<$ http://www.senado.gov.br/atividade/materia/detalhes.asp?p_cod_mate=89535>. Acesso em: 9 set. 2012.

—. Senado Federal. Projeto de Lei PLS n. ${ }^{\circ}$ 259/2007. Dispõe sobre o Programa de Substituição de Embalagens Plásticas Convencionais por Congêneres Biodegradáveis. Disponível em: $<$ http://www.senado.gov.br/atividade/materia/detalhes.asp?p_cod_mate $=81036>$. Acesso em: 5 ago. 2012. 
—. Senado Federal. Projeto de Lei PLS n. ${ }^{\circ}$ 533/2011. Autoriza o Poder Executivo a instituir incentivos fiscais destinados a estimular as pessoas jurídicas que exerçam atividade de controle ambiental de resíduos. Disponível em: $<$ http://www.senado.gov.br/atividade/materia/detalhes.asp?p_cod_mate $=101943>$. Acesso em: 9 set. 2012.

—. Senado Federal. Proposta de Emenda à Constituição Federal PEC no 1/2012. Altera o art. 150, VI, da Constituição Federal, para instituir imunidade de impostos incidentes sobre produtos elaborados preponderantemente com insumos provenientes de reciclagem ou reaproveitamento. Disponível em: $<$ http://www.senado.gov.br/atividade/materia/detalhes.asp?p_cod_mate=104116>. Acesso em: 3 nov. 2012.

RIO DE JANEIRO. Assembleia Legislativa. Projeto de Lei n. ${ }^{\circ}$ 1.415/2012. Estabelece benefícios fiscais para os empreendimentos que detenham qualificação Qualiverde e dá outras providências. Disponível em: $<$ http://mail.camara.rj.gov.br/APL/Legislativos/scpro0711.nsf/1061f759d97a6b24832566e c0018d832/071aea683fd2bbbb03257a1d0071dcf7?OpenDocument>. Acesso em: 03 set. 2012.

SUPERIOR TRIBUNAL DE JUSTIÇA. Disponível em: $<$ http://www.stj.jus.br/SCON/pesquisar.jsp>. Acesso em: 8 jan. 2012.

SUPREMO TRIBUNAL FEDERAL. Disponível em: $<$ http://www.stf.jus.br/portal/jurisprudencia/listarJurisprudencia.asp?s1=\%28RE\%24\%2ES CLA\%2E+E+239397\%2ENUME\%2E\%29+OU+\%28RE\%2EACMS\%2E+ADJ2+239397 \%2EACMS\%2E\%29\&base=baseAcordaos>. Acesso em: 15 fev. 2012. 